WELSON HAVERTON LASSALI RODRIGUES

A GUILHOTINA DE HUME SOB UMA PERSPECTIVA ONTOLÓGICA DO FENÔMENO NORMATIVO. A DECISÃO COMO VERDADEIRO PODER-SER DO DIREITO.

Dissertação de Mestrado

Orientador: Professor Associado Ari Marcelo Solon

FACULDADE DE DIREITO

UNIVERSIDADE DE SÃO PAULO

SÃO PAULO-SP

2016 
WELSON HAVERTON LASSALI RODRIGUES

\title{
A GUILHOTINA DE HUME SOB UMA PERSPECTIVA ONTOLÓGICA DO FENÔMENO NORMATIVO. A DECISÃO COMO VERDADEIRO PODER-SER DO DIREITO.
}

\begin{abstract}
Dissertação apresentada à Banca Examinadora do Programa de Pós-Graduação em Direito da Faculdade de Direito da Universidade de São Paulo, como exigência parcial para obtenção do título de Mestre em Direito, na área de concentração de Filosofia e Teoria Geral do Direito, sob a orientação do Professor Associado Ari Marcelo Solon.
\end{abstract}

Faculdade de Direito da Universidade de São Paulo

São Paulo-SP

2016 
Catalogação da Publicação

Serviço de Documentação Jurídica

Faculdade de Direito da Universidade de São Paulo

RODRIGUES, Welson H. Lassali.

A Guilhotina de Hume sob uma perspectiva ontológica do fenômeno normativo. A decisão como verdadeiro poder-ser do direito. / Welson H. Lassali Rodrigues; Orientador: Professor Ari Marcelo Solon - São Paulo, 2016.

Dissertação (Mestrado) - Faculdade de Direito da Universidade de São Paulo, 2016.

Palavras-chave: filosofia do direito - Guilhotina de Hume fenomenologia - ontologia - positivismo jurídico - crítica - lógica modal - possibilidade existencial - verdade - decisão 


\section{AGRADECIMENTOS}

À minha querida mãe que, com todo seu incontrolável amor e desmedida dedicação, me ensinou que a superação da existência é sempre possível.

Ao Professor Ari Marcelo Solon, por todo seu conhecimento, carinho e companheirismo, fundamentais para a construção desta Dissertação, e cuja sapiência sempre foi e continua sendo causa de orgulho e admiração a todos os seus alunos e colegas.

Ao Professor Alysson Mascaro, que desde a Graduação me fez ótimas sugestões e recomendações.

À Professora Jeannette Maman e ao Professor Celso Lafer, com quem tive o prazer de estudar durante a Graduação, e a quem devo muito por terem consolidado meu amor à filosofia.

Aos meus amigos, às minhas amigas e aos meus familiares, pelos quais apreendi o que é este ser teimoso, complicado e extremamente encantador chamado "ser-com". 


\section{RESUMO}

Pode-se afirmar que a Guilhotina de Hume diz respeito a um conjunto de discussões filosóficas acerca da primazia (enquanto $\pi \rho o ́ \tau \varepsilon \rho o v)$ do ser (Sein) ou do dever-ser (Sollen) ao se fundamentar enunciados de caráter normativo (e, consequentemente, sua validade e aplicação).

O foco deste trabalho é analisar a Guilhotina de Hume sob a perspectiva da ontologia fenomenológica (existencial), em que a dicotomia entre dever-ser e ser será redirecionada, em função especificamente da análise ética e jurídica que será concluída, para a dicotomia necessidade/possibilidade, tal como proposta pela própria tradição filosófica ao tratar da análise das modalidades (ser-real/realidade, ser-possível/possibilidade e sernecessário/necessidade).

Inicialmente será mantido que as discussões em torno do "dever-ser" encontram-se usualmente imbuídas de uma narrativa totalmente dependente do ser-necessário, que na verdade não poderia ser usada para aqueles seres que podem ser diferentes do que são (os

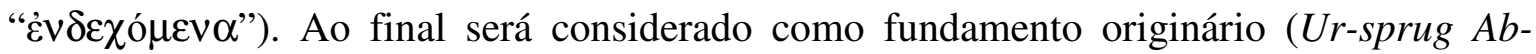
grund) do ser-jurídico o poder-ser existencial (liberdade), revelado que é através de decisões, dramáticas e quotidianas, que não se restringem às decisões de caráter técnico-sacerdotais. 


\begin{abstract}
One might put forward that the Hume's Guillotine relates to a set of philosophical discussions about the primacy (as $\pi \rho \tau^{\tau} \tau \rho o v$ ) either of the being (Sein) or of the ought-to (Sollen) in order to ground normative propositions (and, eventually, their validity and enforcement).
\end{abstract}

This work focuses on the analysis of the Hume's Guillotine under the perspective of the phenomenological (existential) ontology, in which the dichotomy between the ought-to and the being will be redirected, specifically in light of the ethical and juridical analysis that will be carried out, to the dichotomy necessity/possibility, such as proposed by the philosophical tradition on examining the modalities (being-real/reality, being-possible/possibility and being-necessary/necessity).

At the beginning it will be maintained that the discussions over the "ought-to" are usually embedded with a narrative totally dependent on the being-necessary, which in fact could not

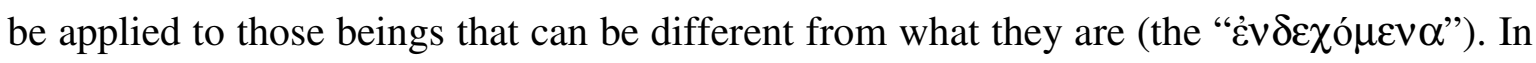
the end, the existential may-be (freedom) will be considered as the original ground (Ursprug Ab-grund) of the being-legal, as reveled through dramatic and everyday decisions, which are not restricted to technical and sacerdotal ones. 


\section{SUMÁRIO}

Página

CAPÍTULO 1. INTRODUÇÃ O ................................................................. 09

1.1. Apresentação geral do tema.................................................. 09

1.2. Metodologia............................................................... 12

CAPÍTULO 2. NORMATIVISMO JUSPOSITIVISTA ….......................... 14

2.1. O fanatismo em torno do juspositivismo............................. 14

2.2. O juspositivismo histórico e seus elementos informadores...... 16

2.3. Rachaduras no edifício juspositivista.................................... 26

2.4. Elementos (in)formadores básicos de uma norma (jurídica)... 29

2.5. Apelo juspositivista........................................................... 35

CAPÍTULO 3. (DEVER-)SER, NECESSIDADE E POSSIBILIDADE...... 40

3.1. Norma: do dever-ser para o poder-ser.................................... 40

3.2. O ser histórico.................................................................... 43

3.3. O ser e a necessidade.......................................................... 48

3.3.1. Rufar mítico do ser-necessário............................................... 48

3.3.2. Narrativas e angústias......................................................... 51

3.3.3. O ser-necessário em Aristóteles.............................................. 61

3.3.4. O ser-necessário no âmbito do ser-jurídico.............................. 65

3.3.5. O fraco necessitante (prático) do ser-necessário....................... 76

CAPÍTULO 4. O PODER-SER …............................................................. 81

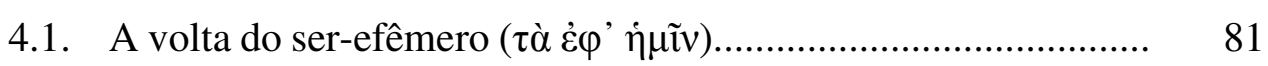

4.2. A possibilidade enquanto ser-potência..................................... 90

4.3. Síntese histórica da lógica modal e a possibilidade meramente 98 modal.

4.3.1. A lógica modal de Gerhard Schurz...................................... 110

CAPÍTULO 5. A POSSIBILIDADE EXISTENCIAL .................................. 117

5.1. Confronto entre o ser-possível e a realidade (ser-real).............. 117

5.1.1. Aristóteles e Heidegger (confluências)..................................... 123 
5.2. O fundamento do ser-jurídico é o poder-ser existencial (decisional) ........................................................................... 140

CAPÍTULO 6. CONSIDERAÇÕES FINAIS............................................... 152

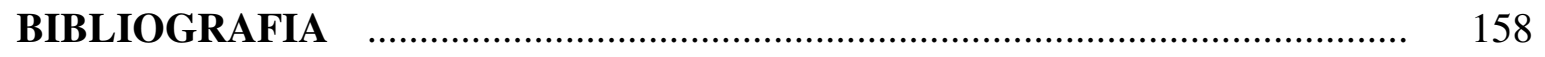




\section{CAPÍTULO 1. INTRODUÇÃO}

\subsection{Apresentação geral do tema}

A presente Dissertação focará sua análise na resistência filosófico-existencial que entendemos existir entre o mundo do ser e o mundo do dever-ser, consubstanciada nas discussões em torno daquilo que a tradição filosófica cunhou como sendo a Guilhotina de Hume.

Referida análise será inclusive construída mediante uma tentativa de superação da dicotomia usualmente levada em consideração quando se tenciona discutir a Guilhotina de Hume (qual seja, ser vs. dever-ser), pela qual apresentaremos uma alternativa lastreada em uma análise modal e ontológica do tema.

Grosso modo, pretendemos empreender uma análise ontológico-existencial das principais discussões jusfilosóficas relativas à Guilhotina de Hume, que poderíamos epilogar como um confronto narrativo pela primazia seja do dever-ser (Sollen) seja do ser (Sein) como fundamento último do direito, o qual, como argumentaremos ao longo desta Dissertação, de fato reside na ideia de possibilidade existencial (poder-ser jurídico), ontologicamente constitutiva de todo ser-humano.

Muito embora a teoria de David Hume não seja o foco de nossa análise (uma ressalva que se faz desde já importante para impedir que o leitor seja encaminhado para uma leitura distorcida do texto abaixo), a questão-tema desta Dissertação foi por ele tangencialmente considerada no último parágrafo da seção 1 da parte 1 do livro 3 do seu $A$ Treatise of Human Nature ${ }^{1}$.

Com efeito, no referido texto David Hume assevera que:

In every system of morality, which I have hitherto met with, I have always remark'd, that the author proceeds for some time in the ordinary way of reasoning, and establishes the being of a God, or makes observations concerning human

${ }^{1}$ HUME, David. A Treatise of Human Nature. Oxford: Oxford University Press, 2009. 
affairs; when of a sudden I am surpriz'd to find, that instead of the usual copulations of propositions, is, and is not, I meet with no proposition that is not connected with an ought, or an ought not. This change is imperceptible; but is, however, of the last consequence. For as this ought, or ought not, expresses some new relation or affirmation, 'tis necessary that it shou'd be observ' $d$ and explain'd; and at the same time that a reason shou'd be given, for what seems altogether inconceivable, how this new relation can be a deduction from others, which are entirely different from it. But as authors do not commonly use this precaution, I shall presume to recommend it to the reader; and am perswaded, that this small attention wou'd subvert all the vulgar systems of morality, and let us see, that the distinction of vice and virtue is not founded merely on the relations of objects, nor is perceiv'd by reason. (HUME, 2009, p. 302).

Cumpre assinalarmos que outros filósofos que analisaram o fenômeno éticojurídico notaram igualmente que há algo de incongruente ou inadequado entre os enunciados ditos normativos, pelos quais "se quer significar que algo deve ser ou acontecer, especialmente que um homem se deve conduzir de determinada maneira"2, e os enunciados descritivos, os quais dialogam com o que é. A incongruência ou inadequação torna-se ainda mais patente quando se tenciona justificar um tipo de enunciado (normativo ou descritivo) pelo outro.

Ainda quanto ao dever-ser, será que sua construção teórica não passaria de uma maneira que os juristas encontraram para salvar os fenômenos ${ }^{3}$, os quais situam-se exclusivamente no mundo do ser e que, de fato, não dialogam com a normatividade? Será mesmo, portanto, necessário focarmos no normativo para apreender ontologicamente o fenômeno jurídico ${ }^{4}$ ?

\footnotetext{
${ }^{2}$ KELSEN, Hans. Teoria pura do direito. - Tradução de João Baptista Machado. $6^{\text {a }}$ ed. - São Paulo: Martins Fontes, 1998, p. 5.

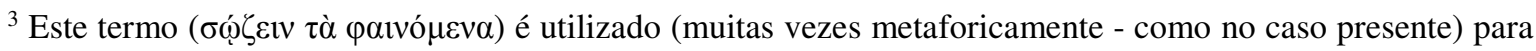
designar as tentativas pós-platônicas de explicar o movimento dos corpos celestes, especificamente no que toca aos planetas que nos são próximos. A explicação "salvadora", a qual resultaria do desafio cosmológico lançado por Platão - a explicação matemática não poderia dar à trajetória dos planetas outro formato que não o de uma circunferência, visto que esta era a forma da perfeição - ao invés de tentar observar o que acontecia no mundo real para depois, sim, formular qualquer hipótese de trabalho especulativo, deu por certa a configuração do movimento celestial (em círculos concêntricos perfeitos) e tentou coadunar as ulteriores observações e medições astronômicas a este dogma, ainda que debalde (já que os planetas efetiva e existencialmente movimentam-se em elipses, como matematicamente demonstrado por Johannes Kepler). Para um melhor detalhamento, cf. KOESTLER, Arthur. Os sonâmbulos: história das concepções do homem sobre o universo. - Tradução de Alberto Denis. São Paulo: IBRASA, 1961.

${ }^{4}$ Nos dizeres do Professor Ari Marcelo Solon, "Ser ou Dever-ser, eis a questão." (SOLON, Ari Marcelo. Dever jurídico e teoria realista do direito. Porto Alegre: Sergio Antonio Fabris, 2000, p. 14).
} 
Neste cenário, o debate jusfilosófico em volta da Guilhotina de Hume tem especial contorno pois lida com questões deveras seminais e originárias ${ }^{5}$ decorrentes da análise do fenômeno jurídico. Ademais, não se trata de um debate eminentemente contemporâneo, sendo possível auscultá-lo já em Platão que, no famoso diálogo Górgias, declara por meio de Cálicles que:

\begin{abstract}
Convention and nature are generally at variance with one another: (...). When Polus was speaking of the conventionally dishonourable, you [Sócrates] assailed him from the point of view of nature; for by the rule of nature, to suffer injustice is the greater disgrace because the greater evil; but conventionally, to do evil is the more disgraceful. (...) The reason, as I conceive, is that the makers of laws are the majority who are weak; and they make laws and distribute praises and censures with a view to themselves and to their own interests; (...) perhaps, according to that artificial law, which we invent and impose upon our fellows, of whom we take the best and strongest from their youth upwards, and tame them like young lions, - charming them with the sound of the voice, and saying to them, that with equality they must be content, and that the equal is the honourable and the just. ${ }^{6}$
\end{abstract}

Em suma, como salientado por Gerard Schurz em sua obra acerca da Guilhotina de Hume?

\footnotetext{
${ }^{5}$ Sobre o alcance, uso e implicações da expressão "originário/a" ao longo desta, trazemos um sintético, embora elucidativo, trecho da explicação apresentada pelos tradutores da obra Der Ursprung des Kunstwerks, escrita por Martin Heidegger e usualmente traduzida para nossa língua como A origem da obra de arte, para sua preferência em traduzir a palavra alemã "Ursprung" como "originário" ao invés de "origem" (sendo que utilizaremos bastante esta ideia ao longo desta Dissertação): "Em português temos como possibilidade de tradução as palavras origem e originário. Ambas vêm do verbo latino oriri, que significa levantar. Embora tenham o mesmo radical, seu significado é bem diferente. Origem diz uma proveniência marcada por um começo e uma causa identificável, inscrevendo-se, portanto no tempo interpretado linear e historiograficamente. Metafisicamente o começo e a causa foram identificados com a essência metafísica. Já originário diz algo bem diferente, pois foge a uma interpretação metafísica. Não se identifica nem com começo nem com causa enquanto essência. Por isso, outra é a compreensão do tempo. É um tempo poético-ontológico que consiste em estar sempre principiando e constituindo realidade. Ele não provém de nenhuma essência essencialista, mas de uma Essência poético-ontológica, que consiste em estar sempre principiando (anfangen) enquanto acontecimento apropriante (Ereignis). Ele é sem fundamento, é Ab-grund, é abissal, é misterioso. É nesse sentido que o alemão diz Ur-sprung: o salto-originário, primordial. Ele não diz, portanto, nenhuma essência essencialista (metafísica). É puro agir, acontecer.” (HEIDEGGER, Martin. A origem da obra de arte. Tradução de Idalina Azevedo e Manuel António de Castro. - São Paulo: Edições 70, 2010, p. 226).

6 PLATÃO. Górgias. - Tradução de Benjamin Jowett. Disponível em: $<$ http://www.gutenberg.org/files/1672/1672-h/1672-h.htm>. Página acessada pela última vez em 10/01/2016.

${ }^{7}$ SCHURZ, Gehard. The is-ought problem: an investigation in philosophic logic. Dordrecht: Kluwer, 1997.
} 
Hume's argument has lost nothing of its importance in present time and probably will never do so. For on the ground of our moral attitudes there is a thicket of intuitions about what is good and what is bad, intuitions which stem from what we have learned throughout our childhood and which usually enter our moral reasoning in an unreflective way. We are easily led to allow certain deep but nevertheless basically subjective intuitions to turn a seemingly factual claim into a normative or valuative assertion, without our taking notice of it. Often, this lack of reflection on their own valuations leads people to a dogmatic attitude, because they mistakenly think of their own moral position as based on 'facts' and thus as being unrefutable, and so they rejecting contradicting positions as obviously irrational. This leads, then, to debates about moral affair which are driven by blind engagement and fanatism, instead of mutual understanding and rational discourse. (SCHURZ, 1997, p. 2, grifos nossos).

Afinal:

[...], the question whether or not the is-ought-thesis is true is practically as well as theoretically highly important. The answer one gives to it is decisive for the basic metaethical question how norms and values can, and how they cannot, be justified. This, in turn, is a crossroads for the construction of divergent ethical systems, e.g. for the decision between modern naturalistic and nonnaturalistic positions in ethics. Moreover, it plays a crucial role in juridical, political and social sciences. (SCHURZ, 1997, p. 7)

E mais, seria o debate entre ser e dever-ser o único caminho para de fato alcançarmos o fundamento originário do fenômeno jurídico? Não poderíamos, quiçá, superá$10 ?$

\subsection{Metodologia}

Não é demais ressaltarmos que durante a pesquisa e elaboração desta Dissertação utilizamos o método usualmente denominado de fenomenológico, sob o viés ontológicoexistencial, construído por Martin Heidegger a partir de sua idiossincrática leitura acerca da sexta investigação lógica feita Edmund Husserl em suas Investigações Lógicas, como método de abordagem a ser utilizado durante a análise que pretendemos dar à discussão sobre a Guilhotina de Hume, tendo em vista sempre o fenômeno jurídico. 
Heidegger fez questão de assinalar que sua investigação ontológica seria conduzida fenomenologicamente: não no sentido de que ele estaria prescrevendo "um ponto de vista" ou uma "corrente" a ser professada, uma vez que "enquanto se compreender a si mesma, a fenomenologia não é e não pode ser nem uma coisa nem outra. A expressão 'fenomenologia' significa, antes de tudo, um conceito de método." 8

Método este que, dentro da linha investigativa ora proposta, almeja a estudar os alicerces jusfilosóficos (e, portanto, originários e abissais) do "fenômeno jurídico", aquilo que é o ser-jurídico.

Neste sentido:

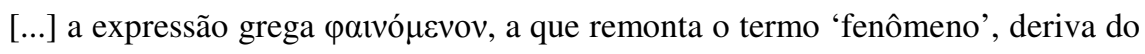

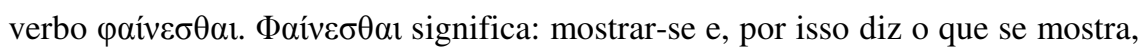

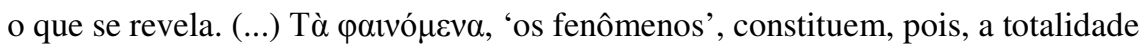
do que está à luz do dia ou se pode pôr à luz, o que os gregos identificavam,

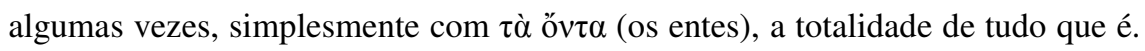
(...) [sendo que] o ente pode-se mostrar por si mesmo de várias maneiras, segundo sua via e modo de acesso. Há até a possibilidade de o ente mostrar-se como aquilo que, em si mesmo, ele não é. ${ }^{9}$

Com relação à obra heideggeriana, salientamos que nossa análise restou focada em sua magnum opus (Ser e tempo), sendo que relegamos para um momento posterior a análise de seus comentários feitos posteriormente à suposta reviravolta (Kehre).

Por fim, com relação às referências e citações feitas ao longo desta Dissertação, utilizamos a padronização adotada pela Associação Brasileira de Normas Técnicas (ABNT), com especial atenção à NBR 6023, à NBR 10520 e à NBR $14724^{10}$.

\footnotetext{
${ }^{8}$ HEIDEGGER, Martin. Ser e tempo. - Tradução de Marcia Sá Cavalcante Schuback. $6^{\text {a }}$ ed. - Petrópolis/RJ: Vozes; Bragança Paulista/SP: Editora Universitária São Francisco, 2012, p. 66.

${ }^{9}$ HEIDEGGER, 2012, p. 67.

${ }^{10}$ Para um melhor detalhamento, cf. CALDAS, Camilo Onoda et al. Manual de metodologia do direito: estudo e pesquisa. - São Paulo: Quartier Latin, 2010.
} 


\section{CAPÍTULO 2. NORMATIVISMO JUSPOSITIVISTA}

\subsection{O fanatismo em torno do juspositivismo}

Arthur Koestler, autor e jornalista húngaro-britânico, certa vez escreveu que todos os mitos costumam crescer tal como ocorre com os cristais (KOESTLER, 1961, p. 9). Contudo, para que possam crescer, haveria a necessidade de "um núcleo adequado" (Id., Ibid.) para tanto. E este núcleo adequado seria necessário pois “as mediocridades e as manias não possuem força geradora de mitos; podem criar uma determinada moda, mas esta não tarda em sumir-se." (Id., Ibid.).

Se existe um corpo mitológico que há tempos manifesta-se com recorrência no direito ocidental e na sua respectiva jusfilosofia, encontrando até hoje franca aceitação por parte de muitos de seus teóricos (e da ampla maioria de seus práticos) é a fábula de que ele, o direito, em sua essencialidade mais própria, advém quase que unicamente do estado contemporâneo, enquanto manifestação de poder 'legítimo', podendo o seu 'núcleo' ser buscado na ideia mesma de norma jurídica.

O direito enquanto norma (ou até mesmo a Norma ${ }^{11}$, para os mais idólatras). O que, até quando e como deve ser, segundo a lei, o judiciário, a moral e os bons costumes. O que se encontra proibido, conforme as garantias constitucionais que informam o dito estado democrático de direito. A hierarquia legal e como superar seus eventuais conflitos linguísticos (se é que conflitos existem, dada a perfeição 'sistêmica' do direito, que tantos veneram).

\footnotetext{
${ }^{11}$ Por uma questão até mesmo metodológica (visando a limitar eventuais processos de sujeiticização, sacralização e pessoalização de nomes, definições, ideais e entes em geral), restringiremos ao máximo o uso de substantivos iniciados com letra maiúscula ao longo deste texto, e faremos exceção apenas a: (i) eventuais lexemas substantivados de origem germânica, dada sua própria gramática; (ii) nomes próprios de qualquer espécie -- incluindo antroponímicos, topônimos, cognomes, patronímicos, designações de comunidades religiosas e políticas, entidades mitológico-narrativas e astronômicas; (iii) nomes de eras históricas e épocas notáveis; (iv) nomes dos pontos cardeais, quando designam uma região; (v) nomes de repartições, agremiações e estabelecimentos em geral; (vi) nomes de fatos históricos e atos solenes; (vii) nomes de escolas de qualquer espécie ou grau de ensino; (viii) eventuais nomes, pronomes ou expressões de tratamento ou reverência; e (ix) títulos de livros, revistas e publicações em geral. Para um maior detalhamento de todos os possíveis usos da letra maiúscula em nosso vernáculo, cf. BECHARA, Evanildo. Moderna gramática portuguesa. 37ª ed. rev., ampl. e atual. conforme o novo Acordo Ortográfico. - Rio de Janeiro: Nova Fronteira, 2009, p. 103-104.
} 
$\mathrm{O}$ que esperar do direito e o que devemos legalmente fazer, sempre segundo a norma, seja ela legiferada, judiciária, costumeira, imposta, meramente quista pelo soberano, reconhecida pelo súdito, contratada, magna ou, até mesmo, apenas hipotéticointuída/pressuposta para tentar validar e legitimar todo o sistema aprioristicamente, como Kelsen tencionou fazer da sua formalista Grundnorm.

Busca-se, enfim, aquilo que deve ser, necessariamente, seja por imposição do direito estatal, seja pela existência de uma justiça atemporal e, muitas vezes, sobre-humana, que funcionaria como um farol objetivador para a conduta humana em qualquer lugar do mundo (ainda que usualmente limitado ao Ocidente, preferencialmente cristão).

Não são poucas as vezes em que os estudiosos do fenômeno jurídico referem-se à (já-dada-como-certa) existência das normas jurídicas e seus efeitos (sejam 'sistêmicos', gnosiológicos, punitivos, valorativos, sociais ou meramente educativos) utilizando um tom de quase-sacralidade ao mencionarem o normativo legal.

Ao longo desta Dissertação, pretendemos lançar mão e discutir outros elementos, ainda que provisórios e filosoficamente modestos, para que possamos considerar o direito além de um insípido (revolucionário-reacionário-neutro-positivo-reativo-etc., a tonalidade muda de acordo com a narrativa vivida/escolhida) aglomerado de normas jurídicas. Referidos elementos, de fato, serão buscados mediante uma superação da usual dicotomia existente ao se tratar da Guilhotina de Hume (ser vs. dever-ser).

Com efeito, sob nosso ponto de vista uma abordagem meramente legalistaidealizada em contraste a uma visão limitada ao fatual parece-nos que na realidade empobrece a discussão, correndo-se inclusive o risco de desnaturá-la na medida em que acaba tomando por certo, de um jeito ou de outro, um conceito que, como esperamos argumentar com persuasão mínima durante o texto, mostra-se de fato um tanto quanto obscuro: a norma; o dever-ser; o Sollen - precipuamente de cunho estatal.

Como pontuado pelo Professor Alysson Mascaro ${ }^{12}$ :

${ }^{12}$ MASCARO, Alysson Leandro. Introdução ao estudo do direito. - $4^{\text {a }}$ ed. São Paulo: Atlas, 2013. 
Pela tradição do pensamento jurídico contemporâneo juspositivista, na norma jurídica se encerra o elemento basilar da ciência do direito. Acostumado à frenética vida prática nos fóruns e na elaboração de negócios jurídicos, o jurista, para tais afazeres, identifica imediatamente a questão do direito àquilo que a norma jurídica tratar. Para ele, sim, obviamente o direito revela-se pela norma: o direito é, na verdade, um conjunto delas. Diz-se, com orgulho, que a ciência do direito não se preocupa em querer dizer quais são essas normas, não quer falar dos seus conteúdos, mas quer dizer sim que, sempre, o direito será composto por normas. Se a média dos operadores quase nunca põe em dúvida a sua certeza de que o direito se resume a um conjunto de normas, é preciso avancar e compreender que o direito é maior que a sua normatividade. (MASCARO, 2013, p. 65, grifos nossos)

Todavia, sugerimos de início que nos embrenhemos, ainda que minimamente, nos elementos informadores do juspositivismo para que, de seus pontos tradicionalmente mais idiossincráticos, possamos observar e discutir as raízes teóricas e práticas de que essa corrente de pensamento se utilizou para fincar sua verdade na filosofia e na teoria geral do direito, a fim de verificarmos se haveria outras alternativas para encaminharmos o debate sobre o fenômeno jurídico.

\subsection{O juspositivismo histórico e seus elementos informadores}

Não há sequer espaço nesta Dissertação para elaborarmos uma antologia, seja ela genética ou estrutural, dos principais pensadores e teorias juspositivistas, sob pena mesmo de escaparmos das principais questões que ainda devemos abordar.

De qualquer maneira, entendemos que uma brevíssima excursão ao originário ( $U r$ sprung) do juspositivismo histórico merece ser repisada.

Tal como ocorre na grande maioria das vezes em que se arrisca tracejar o iter historicamente percorrido pelo Ocidente para alcançar determinado arcabouço conceitual, é argumentativamente possível encontrarmos na Grécia Antiga ${ }^{13}$ a introdução no discurso

13 “[...] a nossa história - na sua mais profunda unidade - [...] 'começa' com a aparição dos gregos. [...] 'Começo' não quer dizer aqui início temporal apenas, mas ainda $\grave{\alpha} \rho \chi \tilde{\eta}$, origem ou fonte espiritual, a que sempre, seja qual for o grau de desenvolvimento, se tem de regressar para encontrar orientação. É esse o motivo por que, no decurso da história, voltamos constantemente à Grécia." (JAEGER, Werner Wilhelm. Paideia: a 
filosófico acerca dos efeitos e legitimação da lei convencionalmente adotada pelos seres humanos $(v o \mu \rho \varsigma)^{14}$, o que ela seria e de onde originariamente saltaria sua força dentro das narrativas comportamentais que lhe são próprias.

Além, por exemplo, do discurso já mencionado de Cálicles no famoso diálogo platônico Górgias, em Heráclito mesmo também já podemos pré-escutar a Hobbes, ainda que um longínquo farfalhar causado pela mais leve brisa, quando nos fragmentos abaixo o Efésio declara expressamente que as cidades gregas ( $\pi$ ó $\lambda ı \varsigma$ ) são fundadas nas leis humanas, convencional e arbitrariamente formuladas pelos homens (ainda que hauridas de uma lei divina), sendo necessário que o povo fosse arregimentado para lutar pela lei como se luta para salvaguardar as muralhas de sua própria cidade.

Tal como transcrita na obra do autor Charles Kahn ${ }^{15}$ :

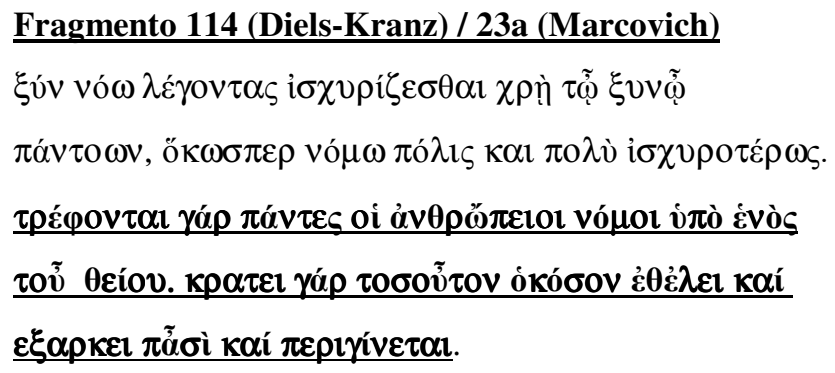

Os que falam com inteligência devem apoiar-se no que é comum a todos, assim como uma cidade se apoia na sua lei, e ainda mais firmemente.

Pois todas as leis humanas nutrem-se de uma só divina. Esta prevalece segundo a sua vontade e basta para todos e ainda sobra. (KAHN, 2009, p. 70, grifos nossos).

\section{Fragmento 44 (Diels-Kranz) / 104 (Marcovich)}

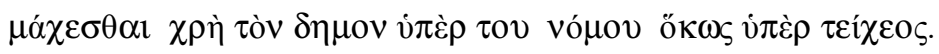

O povo deve lutar pela lei como luta pelas muralhas da cidade. (Ibid., p. 84)

\footnotetext{
formação do homem grego. Tradução de Artur M. Parreira. - $6^{\text {a }}$ ed. - São Paulo: Editora WMF Martins Fontes, 2013, p. 3)

14 "The intrusion of nomos into philosophical discourse in the fifth century followed upon the shift of the notion of nature (physis) from the physical to the ethical realm. This may have been a result of medical influence [...], but can be seen as well in the ethical coloring of the concept of kosmos. From the other side there was an increasing understanding of the purely arbitrary and relative nature of nomos [...]." PETER, Francis Edwards. Greek philosophical terms: a historical lexicon. - Nova York, EUA: New York University Press, 1967, p. 131.

${ }^{15}$ KAHN, Charles H. A arte e o pensamento de Heráclito: uma edição dos fragmentos com tradução e comentário. - Tradução de Élcio de Gusmão Verçosa Filho. São Paulo: Paulus, 2009.
} 
Especificamente no que se refere ao fragmento 44 (DK), acima transcrito, não é tão difícil assim ouvir um principiar dos rufos dos tambores juspositivistas, inclusive aqueles de cunho coacionista. Usando este diapasão como régua, não soaria de fato muito bizarro se simultaneamente ao Efésio recitássemos um dos mais famosos juspositivistas, von Ihering, o qual de pronto inicia uma de suas obras mais famosas ${ }^{16}$ afirmando, em tom um tanto wagneriano:

\footnotetext{
O objetivo do direito é a paz, a luta é o meio de consegui-la. (...) A vida do direito é a luta, a luta de povos, de governos, de classes, de indivíduos.

Todo o direito do mundo foi assim conquistado, todo ordenamento jurídico que se lhe contrapôs teve de ser eliminado e todo direito, assim como o direito de um povo ou o de um indivíduo, teve de ser conquistado com luta.

O direito não é mero pensamento, mas sim força viva. Por isso, a Justiça segura, numa das mãos, a balança, com a qual pesa o direito, e na outra a espada, com a qual o defende. A espada sem a balança é a força bruta, a balança sem a espada é a fraqueza do direito. (IHERING, 2001, p. 27)
}

Dadas as características que lhe são mais afeitas, entendemos todavia que, em comunhão com outros autores ${ }^{17}$, é em Thomas Hobbes (1588 - 1679) em quem podemos buscar a fonte mais originária da qual, três séculos depois, utilizaram-se os autores juspositivistas para construção de seu arsenal conceitual.

Em sua obra mais famosa $(\text { Leviatã) })^{18}$, Hobbes investe diretamente contra Aristóteles e sua teoria de que o homem seria em sua essência um zoon politikon (HOBBES, 2012, p. 138), declarando que a necessidade social somente teria sido formada com a estipulação do contrato social inicial em que os súditos teriam transferido ao soberano o direito de impor leis e demandar obediência, havendo anteriormente um estado de puro individualismo, egoísmo, angústia, medo e insegurança.

\footnotetext{
${ }^{16}$ IHERING, Rudolf von. A luta pelo direito. - Tradução de José Cretella Jr. e Agnes Cretella. $2^{\mathrm{a}}$ ed. São Paulo: Editora Revista dos Tribunais, 2001.

${ }^{17}$ Cf. COMPARATO, Fábio Konder. Ética: direito, moral e religião no mundo moderno. - $2^{\text {a }}$ ed. São Paulo: Companhia das Letras, 2013, p. 203.

${ }^{18}$ HOBBES, Thomas. Leviatã, ou matéria, forma e poder de um estado eclesiástico e civil. - Tradução de Rosina D’Angina. 2a ed. São Paulo: Martin Claret, 2012.
} 
Segundo Hobbes, em um dos excertos filosóficos e políticos mais famosos de todos os tempos, no início haveria uma "situação de desconfiança mútua" entre os homens, em que a "astúcia" e a "força" seriam usadas para tentar "proteger a si mesmo", durante "tempo suficiente para que nenhum outro poder" pudesse ameaçá-lo (HOBBES, op. cit., p. 103). Assim, enquanto não existisse "um poder comum capaz de manter os homens numa atitude de respeito, temos a condição do que denominamos guerra; uma guerra de todos contra todos" (HOBBES, op. cit., p. 104.).

E já perspirando um mínimo juspositivista, Hobbes conclui que:

\footnotetext{
Sem a espada, os pactos não passam de palavras sem força, que não dão a mínima segurança a ninguém. Assim, apesar das leis naturais (que cada um respeita quando tem vontade e quando pode fazê-lo com segurança), se não for instituído um poder considerável para garantir sua segurança, o homem, para proteger-se dos outros, confiará, e poderá legitimamente confiar, apenas em sua própria força e capacidade. (HOBBES, op. cit., p. 139-140).
}

E, para Hobbes, não há dúvida de que o absoluto (e absolutista) poder soberano e estatal do monarca serviria de garantia de segurança, confiança e certeza para a sociedade e seus afazeres quotidianos.

Quanto ao juspositivismo em si, na realidade um dos filhos mais célebres do século XIX mas cujas bases conceituais alcançaram, e foram abraçadas com efusão, pela grande maioria dos teóricos e dos práticos atuantes no século XX (e também muitos que ainda hoje o seguem automatamente), é de rigor afirmar que tal corrente de pensamento encontra-se lastreada em todo o jusracionalismo da Idade Moderna e na escola positivista de pensamento criada por Augusto Comte (1798-1857).

Entretanto, de maneira concisa podemos dizer que o juspositivismo somente veio a aflorar e prosperar com: (i) a plena consolidação dos estados nacionais na Europa ocidental (o que facilitou sobremaneira a identificação do que seria o 'direito vigente', outorgando-lhe uma estranha sistematicidade que, até hoje, alguns estudiosos do fenômeno jurídico necessitam acossar a todo custo); (ii) o efetivo fim das guerras religiosas (Paz de 
Westphalia); e (iii) a eliminação dos principais benefícios que o clero e a nobreza ainda tinham e que bloqueavam a ascensão da burguesia ${ }^{19}$.

O Professor Comparato, com seu famoso rigor e poder de síntese, leciona com muita propriedade ao afirmar que:

A escola positivista, criada no século XIX, procurou transportar para o campo da ética e da vida social o mesmo rigor de análise e raciocínio, próprio das ciências exatas. $[\ldots]$

A partir de Augusto Comte, o pensamento positivista desenvolveu-se sucessivamente no campo filosófico em empiriocriticismo, positivismo lógico, empirismo lógico e, finalmente, no século XX, em filosofia analítica e linguística. Todas essas correntes de pensamento têm em comum os mesmos princípios metodológicos, a saber: 1) o conhecimento humano só pode ter por objeto fatos apreendidos pela experiência sensível; 2) fora do mundo dos fatos, a razão só pode ocupar-se, validamente, de lógica e matemática. O saber fundado nesses dois princípios - o único que pode ser considerado científico - foi denominado por Comte um saber positivo, por oposição ao falso saber, dito metafísico. (COMPARATO, 2013, p. 350-351)

Para que não haja qualquer dúvida acerca da relação de proximidade e mútuo suporte teórico que foram criados entre o direito juspositivista e a tentativa de se fazer uma análise a mais próxima possível dos princípios informadores da lógica e da matemática, o Professor Comparato ainda explica que:

\footnotetext{
Na busca dessa exatidão de raciocínio, os positivistas do direito não podiam considerar objeto da teoria jurídica as ações humanas, em razão de sua variabilidade imprevisível e de sua extrema complexidade. Restavam assim, como objeto próprio de uma análise que se pretendia científica do direito, unicamente os textos normativos, considerados sob dois aspectos: na precisão semântica de seus conteúdos técnicos e no encadeamento lógico das proposições. O direito reduzir-
}

\footnotetext{
${ }^{19}$ Nesta linha, salutar relembrarmos que "a regra do precedente, no direito inglês, ou seja, o dever, para os juízes, de respeitar as anteriores decisões judiciais sobre o mesmo assunto (stare decisis), só se tornou legalmente obrigatória na primeira metade do século XIX, coincidindo com o nascimento da analytical jurisprudence. Na mesma época, a chamada Escola da Exegese, na França, passou a propugnar a interpretação literal dos dispositivos da codificação napoleônica. Em ambos os sistemas jurídicos, os valores políticos supremos foram a certeza $e$ a segurança jurídicas, com a exata previsibilidade das decisões judiciais, como parâmetro invariável para o desenvolvimento da atividade empresarial." (COMPARATO, op. cit., p. 361362, grifos nossos)
} 
se-ia, inelutavelmente, a puras formas normativas. O conteúdo político, econômico, religioso etc. deveria ser expurgado da teoria jurídica, a fim de que ela pudesse pretender a algum rigor científico. (COMPARATO, op. cit., p. 352-353)

Em discussões imbuídas de pressupostos (jus)positivistas, é possível notarmos uma quase-religiosa necessidade de se praticar (mesmo quando a pesquisa é voltada ao social, ao intersubjetivo humano) um ato de (cri)ação teórica em que o estudioso opera uma transubstanciação do continuum espaço-temporal ${ }^{20}$ em expressões e teorias e, claro, justificativas que pretensamente se utilizam do rigor matemático e científico para embasar suas conclusões.

Seus praticantes, que operam não apenas dentre os juristas, parecem carregados de um "Romantismo tardio", como afirmado pelo Professor Nicola Abbagnano em uma obra publicada na Itália em meados da década de $1950^{21}$, em que haveria uma necessidade por teorias ditas puras, infinitas (dado o seu pretenso universalismo), objetivas, absolutas.

Neste sentido:

Per un certo tempo, e per effetto di un tardo Romanticismo, si è insistito sulla 'purezza' della filosofia, cioè sulla sua assoluta indipendenza da ogni altro dato o ricerca, e così è parlato di 'pensiero puro', di 'logica pura', ecc. Ma ridotta a questo stato di purezza, la filosofia perde le sue radici umane, cessa di rispondere a problemi autentici e diventa 'pura' esercititazione retorica. (ABBAGNANO, 1956, p. 2-3)

Em suma: como o Professor Ari Marcelo Solon exemplifica na sua obra Dever jurídico e teoria realista do direito, na parte em que exatamente o Professor trata das (juspositivistas) teorias jurídicas de von Ihering (direito enquanto coação) e Bierling (direito enquanto reconhecimento):

20 Trata-se o continuum espaço-temporal daquela "massa amorfa", como referida por Umberto Eco, com respaldo na teoria semiótica de Hjelmslev, que significaria “todo o exequível, o dizível, o pensável”. Segundo o professor italiano, nós usamos "signos como expressões para exprimir um conteúdo, e este conteúdo é recortado e organizado em diferentes formas por diferentes culturas (e línguas). Sobre o que e por que coisa é recortado? Por uma massa amorfa, amorfa antes que a linguagem tenha operado as suas dissecações, que chamaremos o continuum do conteúdo, todo o exequível, o dizível, o pensável - se quisermos, o horizonte infinito daquilo que é, foi e será, quer por necessidade ou por contingência." (ECO, Umberto. Kant e o ornitorrinco. Tradução de Ana Thereza B. Vieira - Rio de Janeiro: Record, 1998, p. 51, grifos nossos).

${ }^{21}$ ABBAGNANO, Nicola. Possibilità e libertà. - Torino: Taylor Torino Editore, 1956. 
O ponto alto desta teoria [de Ihering] é o esvaziamento do conceito de dever de todo o conteúdo ideal moral. Direito e moral são relativizados e o dever jurídico equiparado a uma relação fática determinada pela coação. [...] Ainda neste rico final de século XIX, propõe Bierling, [...], uma concepção normativista, imperativista e psicologizante do dever jurídico. O conceito de dever já é dado com o conceito de norma jurídica. Todo direito constitui-se de normas. (SOLON, 2000, p. 53, grifos nossos)

Assim, o estudo do direito, e muitas vezes daquilo com o que a própria filosofia do direito deveria em tese ocupar-se para se manter 'útil' para a nova sociedade contemporânea (tecnológica, utilitarista e estatal em seu âmago), acaba reduzindo-se à: (i) aceitação e discussão dos códigos normativos emanados da máquina estatal e das suas decisões (administrativas, legislativas e judiciárias), como se fossem os únicos elementos de criação e propagação do direito; (ii) leitura e exegese dos códigos e decisões "autênticas" (no sentido de autorizadas pelo próprio direito), seguindo princípios hermenêuticos previstos pela própria tecnologia jurídica (que pode sim prestar serviços à sociedade, desde que não para sempre petrificados, como situações modelos irredutíveis de verdade jurídicocomportamental); (iii) discussões tecnológicas - sejam elas acadêmicas, jurisprudenciais, administrativas, etc. - acerca exclusivamente dos textos normativos, sua justificativa (normativa, na maciça maioria dos casos), seu processo legislativo imediato, e sua força cogente dentro de um determinado 'sistema jurídico' (mesmo quando o autor pretende fazer uma análise mais zetética ${ }^{22}$ do que dogmática acerca do tema).

Exemplificando esta antiga (embora ainda hoje pujante) cantilena juspositivista, Lourival Vilanova, em uma obra que trata da pretensa aplicação da lei da causalidade nas relações jurídicas ${ }^{23}$, chegou mesmo a afirmar que:

22 Prestamos aqui nossa homenagem ao Professor Tércio Sampaio Ferraz Júnior, trazendo à lume a diferenciação que ele faz (com base em um texto de Theodor Viehweg publicado em 1969), ao analisar o direito e seus elementos, separadamente caracterizando o enfoque zetético (que visa a perquirir, desintegrar e questionar as opiniões eventualmente já formadas, com função precipuamente especulativa) do enfoque dogmático, pelo qual o jurista analisará a própria doutrina do direito enquanto tal, com clara função diretiva, em que certas dúvidas são estancadas - e na maioria das vezes, proibidas - com a criação de pontos de partida dogmáticos e incontestes). Para uma melhor explicação sobre esta diferenciação, cf. FERRAZ JÚNIOR, Tércio Sampaio. Introdução ao estudo do direito: técnica, decisão, dominação. - $2^{\text {a }}$ ed. São Paulo: Atlas, 1994, p. 39 et seq.

23 VILANOVA, Lourival. Causalidade e relação no direito. - 4ª. ed. São Paulo: Editora Revistas dos Tribunais, 2000. 
$\mathrm{Na}$ lei da causalidade natural, a relação entre hipótese e consequência é enunciativa, descritiva. [...] Por isso, a lei causal natural é verdadeira, se confirmada; falsa, se infirmada.

Na lei de causalidade jurídica há sequências regulares iterativas, cuja expressão lógica é a implicação formal [...]. Mas é o sistema jurídico positivo que estatui, preceitua, preestabelece dentre as possíveis hipóteses e as possíveis consequências as relações que devem ser. $O$ minimum genérico que há nas espécies 'obrigatoriedade', 'proibitividade', 'permissividade, é que tais modos são modos de dever-ser. São modais especificados de um modal genérico, odever-ser. (VILANOVA, 2000, p. 94, grifos nossos)

Para reforçar quão presente e arraigado no debate acadêmico encontra-se o discurso juspositivista acerca do fenômeno jurídico (calcado na ideia de norma), não é pouco salientarmos que o grande pensador e jurista italiano Norberto Bobbio enfaticamente sustenta, já no início de uma de suas obras mais famosas ${ }^{24}$, que:

[...] o melhor modo para aproximar-se da experiência jurídica e apreender seus traços característicos é considerar o direito como um conjunto de normas, ou regras de conduta. [...]: a experiência jurídica é uma experiência normativa. (BOBBIO, 2001, p. 23)

Novamente: para o juspositivismo, a ideia de norma, de dever-ser (Sollen), sua origem estatal e toda sua exegese tecnologicamente construída acabam por dominar, em sua quase integralidade, o debate sobre o direito.

E quão distante este posicionamento encontra-se dos dizeres de Celso que, conforme apontado por Ulpiano no Digesto $(1,1,1$, pr.), teria elegantemente (ou com exatidão, diriam os mais rígidos) definido o direito como ars boni et aequi ${ }^{25}$ !

E tal distanciamento não ocorre apenas na jusfilosofia continental europeia.

${ }^{24}$ BOBBIO, Norberto. Teoria da norma jurídica. - Tradução de Fernando Pavan Baptista e Ariani Bueno Sudatti. Bauru, SP: EDIPRO, 2001.

${ }^{25}$ Sobre os conceitos de direito objetivo, direito subjetivo, bem comum, equidade e justiça no direito romano, cf. ALVES, José Carlos Moreira. Direito romano. - 5a ed., vol. I. Rio de Janeiro: Forense, 1983, p. 91 et seq. 
A fim de não nos prolongarmos demasiadamente sobre o tema, podemos citar Hart apenas como um exemplo anglo-saxão de como a ligação entre direito e norma encontra-se com-sagrada (sic et simpliciter).

Após iniciar uma de suas obras mais famosas (The concept of $l a w^{26}$ ) atacando o que ele via como falhas nas teorias juspositivistas de caráter coacionista-punitivo (como ocorre em Austin), Hart afirma que a raiz e origem de tais falhas, em síntese, decorreria do fato de que:

[...] the elements out of which the theory was constructed, viz., the idea of orders, obedience, habits, and threats, do not include, and cannot by their combination yield, the idea of a rule, without which we cannot hope to elucidate even the most elementary forms of law. (HART, 1998, p. 80, grifos nossos)

E em um post scriptum feito por Hart em 1993, e publicado no ano seguinte, em que o autor basicamente tencionou rebater as críticas que lhe houveram sido feitas por Dworkin, ele expressamente afirma que seu intuito ao escrever The concept of law:

[...] was to provide a theory of what law is which is both general and descriptive. It is general in the sense that it is not tied to any particular legal system or legal culture, but seeks to give an explanatory and clarifying account of law as a complex social and political institution with rule-governed (and in that sense 'normative') aspect. [...]. My account is descriptive in that it is morally neutral and has not justificatory aims: it does not seek to justify or commend on moral or other grounds the forms and structures which appear in my general account of law, [...]. (HART, 1998, p. 239 et seq., grifos nossos).

É quase impossível não cogitar uma analogia direta com o primeiro capítulo da Reine Rechtslehre kelseniana, em que o autor (já classicamente) afirma que:

\begin{abstract}
A Teoria Pura do Direito é uma teoria do Direito positivo - do Direito positivo em geral, não de uma ordem jurídica especial. É teoria geral do Direito, não interpretação de particulares normas jurídicas, nacionais ou internacionais. [...].
\end{abstract}

${ }^{26}$ HART, Herbert Lionel Adolphus. The concept of law. - $3^{\text {a }}$ ed. New York: Oxford University Press, 1998 (reimpressão). 
De um modo inteiramente acrítico, a jurisprudência tem-se confundido com a psicologia e a sociologia, com a ética e a teoria política. Esta confusão pode porventura explicar-se pelo fato de que estas ciências se referirem a objetos que indubitavelmente têm uma estreita conexão com o Direito. Quando a Teoria Pura empreende delimitar o conhecimento do Direito em face destas disciplinas, fá-lo não por ignorar ou, muito menos, por negar essa conexão, mas porque intenta evitar um sincretismo metodológico que obscurece a essência da ciência jurídica e dilui os limites que lhe são impostos pela natureza do seu objeto.

$[\ldots]$.

Ora, o conhecimento jurídico dirige-se a estas normas que possuem o caráter de normas jurídicas e conferem a determinados fatos o caráter de atos jurídicos (ou antijurídicos). Na verdade, o Direito, que constitui o objeto deste conhecimento, é uma ordem normativa da conduta humana, ou seja, um sistema de normas que regulam o comportamento humano. (KELSEN, 1998, p. 1 et seq., grifos nossos).

Enfim, tal como sumarizado pelo Professor Alysson Mascaro em sua obra Filosofia do direito ${ }^{27}$, ao tratar das vertentes juspositivistas do pensamento jurídico contemporâneo:

\begin{abstract}
A norma, a sentença, o processo legislativo, o ordenamento, a isso se reduzirá a preocupação do pensamento jurídico.

É por isso que a filosofia do direito de tipo normativo estatal converte o pensamento jurídico numa espécie de teoria geral do direito. Tudo o que é maior, mais abrangente e mais amplo do que essa teoria geral das técnicas do direito é abominado como não jurídico. Há uma ojeriza quanto ao pensamento jurídico que dialogue ou se relacione com a verdade social. Para os pensadores dessa grande corrente de pensamento, o fenômeno jurídico se limita, por excelência, apenas à técnica jurídica. (MASCARO, 2012, p. 320, grifos nossos).
\end{abstract}

Mas será mesmo que a análise da referida normatividade estatal per se é capaz de nos fazer captar o conteúdo, abrangência e possibilidades do dito sistema normativo, a ponto de termos convicção de seus limites e em suas ferramentas confiarmos? Será mesmo que o conhecimento normativo deste pretenso objeto, o direito, seria capaz de auxiliar a sociedade como um todo, e não apenas os iniciados, a tomar suas decisões em seu dia-a-dia?

${ }^{27}$ MASCARO, Alysson Leandro. Filosofia do direito. - 2a ed. São Paulo: Atlas, 2012. 
Seria, enfim, o direito posto o verdadeiro fundamento existencial e comportamental do fenômeno jurídico?

E mesmo aos iniciados, às novas sacerdotisas e sacerdotes tecnológicos, será a normatividade realmente clara e objetiva, como apregoa a dogmática, cabendo, quando muito, uma interpretação de seus termos e abrangência? E se esta realidade objetiva e alcançável não o for, o que nos restaria? O caos?

\subsection{Rachaduras no edifício juspositivista}

Parece-nos que muito da força argumentativa e da intercorrente presença histórica do juspositivismo vêm do aparente sentimento de segurança e certeza que ele arrasta consigo.

Esta fidúcia no normativo inclusive é vista como meio de facilitação do processo decisório em si (seja no âmbito judicial, arbitral, familiar, individual, etc.) pois, a partir de sua pretensa objetividade e igualdade, as regras estariam claramente à mão de qualquer um que delas dependesse para decidir, em sua quotidianidade, e que delas certamente lançaria mão inclusive para fazer valer seus direitos, se necessário.

A dogmática jurídica, frequentemente entendida como a manjedoura, guardiã e (mormente) ataúde dos conceitos normativos, que em sua pureza metodológica tenta alcançar e professar o 'correto', o 'válido', o ‘jurídico' do mundo através da análise das objetivas e formalmente igualitárias normas estatais, individual ou sistemicamente consideradas, seria mesmo capaz de individualizar objetivamente o seu objeto? E como ela auxiliaria os indivíduos a tomarem suas decisões?

Com base em uma objetiva análise normativa do fenômeno jurídico, os agentes econômicos podem, com segurança, tomar suas decisões quotidianas? Em outras palavras: os agentes econômicos têm mesmo acesso e confiam, seja no direito ou em sua “interpretação autêntica”, termo muitas vezes usado pelos adeptos à tradição juspositivista ${ }^{28}$ ?

\footnotetext{
${ }^{28}$ Pois, mesmo para o normativista mais ferrenho, não é possível deixar de perceber que há muito mais do que uma única interpretação que pode ser atribuída a determinada "norma", seja lá o que isso signifique, em função mesmo da plurivocidade dos seus termos, do seu alcance prático e da complexidade das situações
} 
E já aí teríamos muitas dificuldades para apreensão e solução do problema, dada a pletora de forças socioeconômicas e a exuberância das narrativas existenciais/comportamentais envolvidas.

Para começar, poderíamos perguntar: quem ou o que verdadeiramente é a fonte de onde emana este conjunto de normas (pois, pressupondo que tais normas foram criadas pela humanidade, e não por uma força superiora a extramundana, aparentemente não deveria ser difícil localizar sua nascente)? Qual é o seu efetivo fundamento originário e abissal (Ursprung Ab-grund $)^{29}$ ?

Em uma república federativa como a nossa, tradicionalmente a dogmática tenderia a tratar o Congresso Nacional, órgão editor de atos normativos que em tese atuaria como a voz majoritária do povo brasileiro, indiretamente reunido em assembleia, como a fonte última do direito, e local em que o caminho que se deve necessariamente seguir é traçado por meio das próprias normas que de lá emanam.

existencialmente envolvidas. Assim, aceita-se que não apenas o legislativo, mas também os tribunais judiciários, administrativos ou arbitrais - são fontes de direito à medida que criam as tais normas jurídicas. Neste diapasão, Kelsen afirma que "a interpretação feita pelo órgão aplicadora do Direito é sempre autêntica. Ela cria Direito" e continua mais a frente, afirmando que "[...] autêntica, isto é, criadora de Direito é-o a interpretação feita através de um órgão aplicador do Direito ainda quando cria Direito apenas para um caso concreto, quer dizer, quando esse órgão apenas crie uma norma individual ou execute uma sanção.” (KELSEN, 1998, p. 394).

${ }^{29}$ A título de chave de interpretação, sugerimos desde já acomodar o conceito de fundamento (e mais ainda, o fundamento dito abissal) não a partir da ideia de "razão suficiente" como sustentada por Leibniz (nihil est sine ratione; nada existe sem razão, ou, de outra forma, tudo tem uma razão), mas a partir do conceito helênico (e

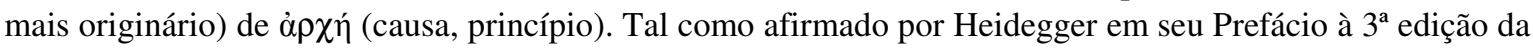
obra A essência do fundamento (Von Wesen des Grudes) (HEIDEGGER, Martin. A essência do fundamento. Tradução de Artur Morão. - Lisboa: Edições 70, 1988), "Aristóteles resume a sua exposição dos múltiplos significados da palavra 'começo' [á $\chi \chi \eta ́]$ deste modo: 'é, pois, comum [Kolvòv] a todos os começos

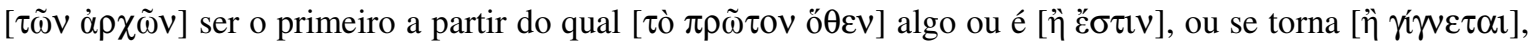
ou se conhece [ì $\gamma \nmid \gamma \omega \dot{\sigma} \sigma \chi \varepsilon \tau \alpha \mathrm{l}]$ '. Assim se realçam as variações do que costumamos chamar 'fundamento': o fundamento da quididade [Was-seins], do facto-de-ser [Daß-seins] e do ser-verdade [Wahr-seins]. Mas, além disso, procura também determinar-se em que é que estes 'fundamentos' enquanto tais se acordam. O seu

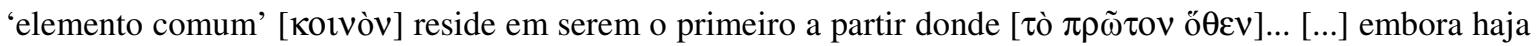
que duvidar de se a essência do fundamento se poderá encontrar mediante uma caracterização do que é 'comum' às 'espécies' de fundamentos, não deve, no entanto, desconhecer-se aí o impulso para um originária clarificação [ursprünglichen Erhellung] do fundamento em geral.” (HEIDEGGER, 1988, p. 8-11). E conclui que o verbo <fundamentar> "[...] não deve aqui tomar-se no sentido estreito e derivado da prova de proposições ôntico-teoréricas, mas numa simplificação basicamente originária. Por conseguinte, fundamentação significa o mesmo que possibilitação da questão do porquê em geral. Clarificar o caráter peculiar, originalmente fundador, do fundamentar significa, pois, elucidar a origem transcendental do porquê como tal." (HEIDEGGER, 1988, p. 95). 
Com o tempo, entretanto, os próprios juspositivistas admitiram a possibilidade de uma 'interpretação autêntica', já referida acima, em que se consentiu que o direito fosse também formado a partir das decisões tomadas pelos tribunais, atualmente entendidos como abarcando não apenas os judiciários, mas ainda também os arbitrais e os administrativos.

Mas quão discrepantes e contraditórias as decisões e, por conseguinte, as normas se nos apresentam! As mudanças jurisprudenciais, que em tese poderiam ser compreendidas como fundamentais para superar a própria rigidez e frieza da norma (dura lex, sed lex), por vezes acabam prestando desserviços dada a mudança imoderada (e muitas vezes injustificada) do paradigma em uso pelos sacerdotes (ou operadores, como queiram) do direito.

Imaginemos um exemplo em que um determinado agente econômico tencionava adquirir certa empresa no Brasil, e que seus consultores verificaram, no curso da due diligence jurídico-contábil por eles conduzida, que referida empresa poderia ou não ter a obrigação de contingenciar contabilmente um gigantesco passivo tributário a depender exclusivamente do efetivo prazo de decadência e prescrição da obrigação de pagamento de Imposto de Renda e Contribuição Social sobre o Lucro Líquido a ser adotado (o que, no frigir dos ovos, imporia uma queda brutal no preço de aquisição em negociação).

Ainda dentro deste exercício de conjecturas, podemos imaginar que a referida empresa não fez, à época competente, o contingenciamento contábil que os consultores do agente econômico veem agora como necessário, sendo que a ausência de tal contingência no passivo contábil da empresa é por eles vista como a grande red flag para a pretendida operação de compra da empresa (a depender, ad argumentandum tantum, exclusivamente do efetivo prazo de decadência e prescrição do crédito tributário envolvido). E o contingenciamento não foi feito exatamente porque, à época da ocorrência do fato gerador, foi instruída por seu corpo de advogados para tanto (e pressupomos que havia de fato fundamento argumentativo para suas conclusões).

Ocorre que a opinião dos advogados, passados alguns anos, pode eventualmente deixar de ser verdadeira em função de mudanças na jurisprudência administrativa aplicada pela Receita Federal, muitas vezes usadas como base exclusiva para os pareceres das 
empresas focadas em auditoria jurídico-contábil, sem que tenha ocorrido qualquer modificação legislativa ou mesmo econômica que justificasse a alteração de curso.

Sem contar que cada Delegacia Regional da Receita Federal, em função até mesmo das idiossincrasias de cada região do Brasil, pode inclusive possuir uma interpretação diferente sobre a matéria em questão, tornando mais difícil ainda o aconselhamento jurídico a ser dado aos agentes econômicos em geral para fundamentar suas decisões empresariais, dada a óbvia e patente instabilidade hermenêutica vigente.

O exemplo acima visou apenas a ilustrar as dificuldades práticas que podemos enfrentar ao lidarmos com a pretensa estabilidade que seria própria e inerente à norma jurídica, mas que aparentemente pode ser alterada de maneira muito mais instável ao considerarmos a multiplicidade interpretativa e decisionária à mão. Isso se aplicada for!

De qualquer maneira, entendemos que para prosseguirmos precisamos ainda aprofundar um pouco mais o debate sobre o que seria esta norma jurídica, visto que nos parece evidente que todo o edifício juspositivista sobre ela foi erigido, com todos os seus acólitos e pressupostos.

\subsection{Elementos (in)formadores básicos de uma norma (jurídica)}

Todavia, nos parece que sequer temos um mínimo de resposta para uma questão anterior que vinha inicialmente permeando esta Dissertação: como se definiria uma norma jurídica, a mônada do juspositivismo, que a este parece conferir sustentáculo, propriedade e estabilidade? Como discriminar seus elementos de maneira clara? O que distingue uma norma ética de uma religiosa, ou uma norma ética daquelas ditas jurídicas?

Em outras palavras: o que é uma norma?

Obviamente seria possível enumerarmos e discutirmos vários outros elementos linguísticos/comunicacionais que frequentemente repetem-se - muitas vezes de maneira maçante - ao longo de todos os discursos e narrativas juspositivistas para o fim de tentar aprofundar o que seria uma norma jurídica. Dentre estes elementos, podemos usar, novamente a título de simples exemplos: 
(i) o debate entre validade (em tese, ideal) versus eficácia (em tese, real) da norma, e como a norma, enquanto esquema de interpretação jurídica (conforme lecionado por Kelsen ${ }^{30}$ ) alcançaria e modificaria o mundo real por ser o que, em tese, efetivamente faz impor/autorizar/proibir condutas em geral;

(ii) a conceituação do que seria uma obrigação jurídica, e de onde adviria o dever de cumprimento (seara própria daqueles que buscam uma justificação para o jurídico e para a sua normatividade, seja esta estática - quando se tenta dar coesão interna na aplicação de uma norma isolada -- seja dinâmica - quando se tenta dar coesão externa, 'sistêmica', ao panteão jurídico);

(iii) as diferenciações feitas entre autorizações/permissões/concessões jurídicas, recomendações, proibições de todo gênero, presunções (absolutas e relativas; processuais ou materiais), etc., que servem basicamente para determinar o que podemos e o que não podemos fazer, ao serem pretensamente entendidas como o conteúdo material das ditas normas jurídicas, o qual determinaria no final das contas qual caminho prático a sociedade deveria perseguir;

(iv) até mesmo os discursos envolvendo as próprias ideias de justiça e de equidade, as quais apesar de serem normalmente analisadas como acima ou além do direito positivo, constituindo muitas vezes uma verdade ou ajuste, naturais e imutáveis, para contrabalancear o peso da dura lex, acabam muitas vezes sendo analisadas e debatidas utilizando como elementos informadores aqueles abiscoitados da mesma sopa juspositivista que a tudo alimenta ( $\underline{\text { e limita) }}$ dentro deste tipo de debate, como o excerto kelseniano a seguir, retirado de sua obra acerca do problema da justiça ${ }^{31}$, é capaz de demonstrar:

O conceito de justiça deve ser distinguido do conceito de direito. A norma da justiça indica como deve ser elaborado o direito quanto ao seu conteúdo, isto é,

\footnotetext{
30 "A norma funciona como esquema de interpretação. Por outras palavras: o juízo em que se enuncia que um ato de conduta humana constitui um ato jurídico (ou antijurídico) é o resultado de uma interpretação específica, a saber, de uma interpretação normativa." (KELSEN, 1998, p. 4).

${ }^{31}$ KELSEN, Hans. O problema da justiça. - Tradução de João Baptista Machado. $2^{a}$ ed. São Paulo: Martins Fontes, 1996.
} 
como deve ser elaborado um sistema de norma que regulam a conduta humana, normas essas postas por atos humanos e que são global e regularmente eficazes ou seja, o direito positivo. Visto a norma da justiça prescrever um determinado tratamento dos homens, ela visa - como já se mostrou - ao ato por meio do qual o direito é posto. $\underline{\text { A justiça não pode, portanto, ser identificada com o direito }}$. (KELSEN, 1996, p. 65, grifos nossos)

Claramente a norma jurídica (ou dever-ser jurídico ${ }^{32}$ ) é um dos elementos linguísticos (proposicionais) que sempre acaba por manifestar-se com maior frequência nos debates acerca do direito, ainda que sub-repticiamente, pois, como dissemos, aparentemente é ela o que daria o verdadeiro sustentáculo abissal e originário a todo o edifício conceitual juspositivista.

Nesta linha, há algumas ilações que podem ser feitas:

a) pela teoria juspositivista de pensamento, o direito passa a ser encarado como um conjunto de normas coativas válidas, havendo uma identificação estrita entre direito e produção estatal - legislativa/judiciária/administrativa;

b) por outro lado, a norma jurídica seria composta de pelo menos 2 (dois) elementos, quais sejam:

(i) uma proposição de natureza prática (no sentido de, a princípio, estar de algum modo visando a impor/sugerir/chantagear uma determinada ação para a conduta humana, diferentemente de uma proposição de cunho descritivo);

(ii) uma sanção, isto é, uma atividade heteronômica visando a acoimar aqueles que ousarem não seguir o comando/imperativo/sugestão/proibição/recomendação embutido na norma (no caso das sanções punitivas), ou laurear aqueles que

\footnotetext{
32 Para os fins a que se destina esta Dissertação, de ora em diante usaremos o termo 'norma' como sinônimo de "dever-ser" (Sollen), ressaltando-se que o conceito de norma não se restringe apenas à norma jurídica (há ainda as normas éticas/morais, as religiosas, as costumeiras, e por aí vai).
} 
satisfizerem os preceitos correspondentes (no caso das sanções premiais).

Desta feita, entendemos que para o juspositivismo o fenômeno jurídico, em sua essencialidade, possui de alguma forma um papel linguístico-comunicacional com o fim de impor/alterar/coordenar a ação humana, e ele encontrar-se-ia em estreita e inexorável ligação com a própria possibilidade de imposição estatal de uma sanção em caso de descumprimento da norma na medida em que a conduta seria juridicamente inadequada. Para tanto, existiria a norma criada exatamente pela própria máquina estatal, que a tudo vigiaria, instruiria, conduziria e, se contestada, puniria (ou premiaria se incentivadora for).

Como afirmado por Kelsen:

\footnotetext{
O Direito só pode ser distinguido essencialmente da Moral quando [...] se concebe como uma ordem de coação, isto é, como uma ordem normativa que procura obter uma determinada conduta humana ligando à conduta oposta um ato de coerção socialmente organizado, enquanto que a Moral é uma ordem social que não estatui quaisquer sanções desse tipo, [...]. (KELSEN, 1998, p. 71).
}

Assim, a hipótese tradicionalmente aceita pelo juspositivismo é a de que o direito encontra-se apartado da moral, da religião e da ética não apenas por ser um conjunto de normas (em tese, a moral, a religião e a ética também o seriam), mas dada a heteronomia da coação/sanção, que se torna inclusive parte integrante do próprio conceito de direito (pelo o que se diz, desde Kant, que a norma jurídica é "uma esfera exterior do dever", e não interior como no caso da moral e da ética ${ }^{33}$, enquanto relação entre a vontade que institui a norma e o alvo de sua instituição/conduta esperada).

Como é possível notar das discussões acima, sempre há uma estreita ligação nas análises juspositivistas entre o ser-jurídico, identificado aprioristicamente em suas normas (dever-ser), e a linguagem. Mas que tipo de 'proposição' linguística seria essa sugerida por von Ihering que, conforme excerto acima, seria um "simples pensamento" visando à ação prática, e que nos parece funcionaria como núcleo do fenômeno jurídico? E mais: seria de

${ }^{33}$ MASCARO, 2012, p. 223. 
fato possível alcançar o efetivo caráter ontológico e constitutivo do direito (ser-jurídico) mediante proposições linguísticas?

Ademais, linguisticamente, o que distinguiriam as proposições normativas das proposições não normativas? Haveria diálogo entre elas? Funcionariam as proposições normativas como "esquemas de interpretação" acerca do mundo do ser, como gostaria o primeiro Kelsen (da Reine Rechtslehre), emprestando a qualquer ato humano individualmente considerado "o significado de um ato jurídico (ou antijurídico)." (KELSEN, 1998, p. 4)?

Além do mais, há alguma correspondência (considerada como referência comunicacional, e não como verdade correspondencial) entre as proposições normativas e o mundo factual? Como se relacionam as proposições normativas com a realidade, aquilo que se nos apresenta desde-sempre-e-agora em sua instintividade e obviedade imediatas, desvelando e sendo desvelada em um eterno movimento de (des)cobrimento?

Partamos novamente do genial Kelsen, mas agora a partir do estudioso já expatriado, que em um livro ${ }^{34}$ inicialmente publicado em solo norte-americano traz a lume, com sua consagrada capacidade de síntese, outros elementos que podem auxiliar nossa construção argumentativa:

Denominamos 'norma' uma regra que determina ou proíbe certa conduta. O significado específico de uma norma é expresso pelo conceito de 'dever-ser'. Uma norma implica que um indivíduo deve fazer ou abster-se de fazer algo. Enunciados que expressam normas são enunciados de 'dever-ser'. Uma conduta é ilícita se 'corresponde' a uma norma jurídica; é ilícita se 'contradiz' uma norma jurídica; ela 'contradiz' uma norma jurídica se está em relação de oposição polar a essa conduta que é lícita. Também podemos dizer: um indivíduo conduz-se licitamente se conduzir-se como deve conduzir-se segundo a norma jurídica; ele se conduz ilicitamente se não se conduzir como deve. O juízo jurídico de valor de que uma conduta é lícita ou ilícita é uma asserção de uma relação afirmativa ou negativa entre a conduta e uma norma cuja existência é pressuposta pela pessoa que faz o juízo. Assim, um juízo jurídico de valor pressupõe a existência de uma norma, de um 'dever-ser'. O significado desse juízo de valor, consequentemente,

${ }^{34}$ KELSEN, Hans. O que é justiça?: a justiça, o direito e a política no espelho da ciência. - Tradução de Luís Carlos Borges. $3^{\mathrm{a}}$ ed. São Paulo: Martins Fontes, 2001. 
depende do significado da asserção de que uma norma 'existe'. (KELSEN, 2001, p. 204-205, grifos nossos)

Em um primeiro esforço na linha de tentarmos facilitar o processo de (des)construção do dever-ser, propomos que do excerto supra transcrito ressaltemos os seguintes pontos, em apertadíssima síntese:

a) primeiro: uma norma seria uma "regra", que obrigaria ou proibiria determinada conduta humana;

b) segundo: normas existem/são/ocorrem/estão no mundo;

c) terceiro: os juízos jurídicos de valor pressuporiam que normas existem/são/ocorrem/estão no mundo, como se entes ou seres patentemente fossem;

d) quarto: os juízos jurídicos de valor são asserções de uma "relação afirmativa ou negativa" entre a conduta humana e uma norma, "cuja existência é pressuposta pela pessoa que faz o juízo";

e) quinto: a mencionada "relação afirmativa ou negativa" entre conduta humana e norma jurídica também pode ser tratada dentro do binômio correspondênciacontradição.

Novamente, contudo, temos a impressão de que permanecemos a correr atrás de nosso próprio encalço, pois, para fins de elucidação teorética, afirmar que uma norma é uma regra é o mesmo que declarar que metade de doze equivale a meia dúzia.

Há outro elemento que Kelsen menciona em sua tentativa de definir uma norma jurídica que entendemos pode trazer mais luz, cor e tragicidade às discussões nesta Dissertação travadas: a norma é uma regra que ou obriga ou proíbe determinada conduta.

Seriam então somente a obrigação e a proibição os elementos formadores do cerne daquilo que estamos chamando de norma? Obrigar e proibir são assim os únicos meios pelos quais a (bem-, mal-) dita norma jurídica atua no agir humano? Se normas são regras, parece- 
nos que normas jurídicas são regras jurídicas. Já nos antecipando, os funtores deônticos ("ser-obrigado", "ser-proibido", "ser-autorizado", etc.) seriam, desta maneira, a essência do fenômeno conhecido como direito?

\subsection{Apelo juspositivista}

Esquecendo momentaneamente o fato de o juspositivismo viver de modo dependente e vinculado a uma mônada mal definida (a norma jurídica), há críticas de cunho prático que merecem realce imediatamente, antes de prosseguirmos.

Além das dificuldades e anfibologias existenciais que muitas vezes são verificadas quando da pretensa aplicação de uma norma a um caso concreto (que, em tese, apenas criaria outra norma, de cunho mais individual, por meio de uma 'interpretação autêntica'), durante o século XX ficou claro como os sistemas políticos podem redundar em monstros históricos ao utilizarem um conceito vazio (e, pela sua própria generalidade, facilmente manipulável) como a norma (ou outros de seus acólitos, também similarmente vagos e perigosos se usados como fundamento, como a soberania, a cidadania, o estado, o bem-comum, o absoluto, o povo, a raça perfeita, etc.) para justificar atos que causaram, e ainda causam, repugnância extrema.

Como muito bem admoestado pelo Professor Fábio Konder Comparato, parece-nos claro que a consolidação e quase-indiscutibilidade da verdade juspositivista, acompanhada que foi da elevação da norma e do legalismo a objeto de quase adoração religiosa, auxiliou sobremaneira a criação dos estados totalitários e fascistas que proliferaram como a Peste Negra no início do século XX.

Conforme o magistério sempre preciso do Professor Comparato:

[...], com a afirmação da simples legalidade formal como fator de legitimidade política, e pela redução da Constituição ao nível de mero ordenamento dos órgãos estatais, qualquer que seja a finalidade última perseguida pelos governantes, é inegável que os positivistas do direito contribuíram, decisivamente, para o surgimento, no século XX, de um dos piores monstros que a humanidade jamais conheceu em toda a sua longa história: o Estado totalitário. (COMPARATO, 2013, p. 363, grifos nossos). 
Trata-se então o positivismo de um simples erro de cálculo, capaz de abusos imensuráveis, e que deve ser abolido de qualquer maneira para se evitar o retorno do homem à sua época precultural?

Servirá o juspositivismo tão somente para ser maleficamente usado para legitimar o conteúdo de qualquer direito e sistema político, desde que tais normas sejam validamente produzidas pelo estado (soberano), competente para tanto? Ou, quando bem-intencionado, acaba por somente criar dificuldades para se entender o que de fato o fenômeno jurídico teria a nos dizer?

Parece-nos essencial que reconheçamos desde já que o juspositivismo não foi, e continua não sendo, uma simples modinha teorética que surgiu do lugar-algum, fadada a desaparecer muito em breve, e não é à toa que suas bases conceituais sirvam até hoje, sobremaneira, como suporte teórico para que muitos expliquem o fenômeno jurídico e justifiquem sua força dita normativa (a qual tende a ser encarada como supostamente objetiva, impessoal e, antes de mais nada, válida erga omnes segundo os procedimentos para tanto previstos pela própria normatividade).

Com efeito, podemos dizer que há um apelo, um furor mesmo, no bojo da teoria e prática juspositivistas que faz com que haja tantos e tão fiéis propugnadores, há tanto tempo.

De onde advém este apelo, esse chamamento, à causa juspositivista?

Somos deste modo tentados a questionar (na linha utilizada por Koestler no excerto que fizemos constar no início deste Capítulo): seria mesmo a norma jurídica efetivamente o "núcleo adequado", a "força geradora" do mito juspositivista, em volta do qual os seus cristais agregaram-se de forma a dar sustentáculo ainda hoje à grande parte do debate que argumenta ser o direito um mero conjunto sistemático de normas?

Ademais, e sendo mais pontual, conseguiria o juspositivismo apreender todas as acepções, discussões e resultados sociais decorrentes do fenômeno jurídico? 
Como já deixamos entrever, entendemos que a verdadeira força originária e fundante (Ur-sprung Ab-grund) do fenômeno jurídico não advém de sua pretensa mônada, a norma, em qualquer de suas vestes.

As peculiaridades e notas próprias do mito continuam até hoje a ressoar e aparentemente mostrarem-se adequadas para justificar o fenômeno normativo em vista mesmo da força narrativa (sempre pragmática e comportamental) decorrente do vetor mímesis-mythos que a fábula composta pela tríade segurança (fim das guerras de religiãoprivilégios feudais)/certeza (unificação do que é considerado direito)/coerência (o direito enquanto sistema) trouxe (ou jura possuir) ${ }^{35}$.

Mas para que possamos tentar retirar a norma do pedestal de infalibilidade a que foi elevada a partir da consolidação do normativismo e do juspositivismo no século XIX, entendemos que ainda precisamos buscar outros elementos na tradição filosófica, não bastando uma mera crítica genérica aos seus elementos informadores básicos.

Ademais, considerando o tema desta Dissertação, pretendemos buscar estes elementos adicionais na literatura filosófica para o fim mesmo de averiguarmos se a alegada separação entre ser e dever-ser (a Guilhotina de Hume), bem como a separação entre todas as esferas normativistas (ética, moral, direito, religião, etc. ${ }^{36}$, teria de fato sustentáculo na existência, seja do indivíduo seja da sociedade em que ele encontra-se alojado.

Partindo novamente da visão hegemônica, advinda do e mantida pelo juspositivismo, parece-nos que o pensamento jurídico usualmente tende a transpirar uma certeza quando utiliza a norma como fundamento para si e para suas construções conceituais, uma garantia mesmo para o funcionamento harmônico do sistema construído pelo próprio

\footnotetext{
35 “As qualificações éticas vêm do real. O que depende da imitação ou da representação é a exigência lógica de coerência. [...] Portanto, que os caracteres possam ser melhorados ou deteriorados pela ação é algo que o poeta sabe e pressupõe. [...] Em suma, para que se possa falar de 'deslocamento mimético', de 'transposição' quase metafórica da ética para a poética, é preciso conceber uma atividade mimética como ligação e não apenas como corte. [...] Se não resta dúvida de que o termo mÿthos marca a descontinuidade, a própria palavra práxis, por sua dupla filiação, garante a continuidade entre os dois regimes, ético e poético, da ação". RICOEUR, Paul. Tempo e narrativa. - Tradução de Claudia Berliner. - vol. I. São Paulo: Editora WMF Martins Fontes, 2010, p. 84 et seq.

36 Sob nossa perspectiva, esta linguagem da separação objetivadora é característica do movimento juspositivista, dada sua sanha de analisar, sob pretensas vestes neutras, o fenômeno jurídico sempre fazendo o "corte epistemológico" proposto por Kelsen.
} 
pensamento jurídico: a norma tem sua existência pressuposta pela pessoa que faz qualquer tipo de juízo jurídico, não importando o fim a que se presta este juízo (na elaboração das leis, no julgamento de um caso criminal, na hora de exarar uma decisão administrativa, o memorando emitido por um parecerista, etc.).

E esta certeza adviria do fato de que, para se fazer qualquer tipo de juízo jurídico, seria necessário, inexoravelmente, pensar e pressupor que a norma é. A norma (o dever-ser), de alguma forma, está ligada ao ser, sendo inclusive considerada (pelo menos no quotidiano jurídico, quase que incontestavelmente) como um existente (ente, ens).

E assim, inicia-se um relacionamento entre o mundo do dever-ser, aquele comando emanado (e justificado) na ideia de norma estatal (ou da comunidade de estados), e o mundo do ser, aquilo que é, que existe, que se nos presentifica diuturnamente.

Relacionamento este que é o foco principal do debate que usualmente é travado ao se discutir a Guilhotina de Hume: o diálogo entre o dever-ser (a norma, o Sollen) e o ser (o mundo fático-fenomênico, o Sein), com ardorosos partidários que argumentam (muitas vezes sob as vestes - inadequadas - da demonstração científica) sob as vantagens e desvantagens de um e de outro, como fundamento originário para o direito.

Entretanto, e como intencionamos melhor construir ao longo desta Dissertação, propomos que o referido relacionamento de fato transcenda à sua usual dicotomia entre aqueles que defendem a norma (idealizada, cultural, gnosiológica, tridimensional, etc.) como base principiológica e fundadora do direito (para fins de simplificação, os normativistas/juspositivistas) e aqueles que defendem que tal base, no final das contas, seria encontrada no ser, independentemente deste manifestar-se sob a forma de voluntariosos imperia emanados do soberano em si, individualmente considerado (will theory), ou de ideológicos subprodutos da estrutura capitalista de alienação do homem (Marx), ou de atos comunais de caráter anti-estatal (tal como exemplificaria a Freetown Christiania, localizada em Copenhagen), estados psicológico-linguísticos de imposição-aceitação visando ao controle/manutenção da ordem social (Olivecrona, Petrazycki) ou, até mesmo, simples fórmulas mágicas (Hägerström). 
Nossa proposta, ao contrário, é a de realçar o lado da possibilidade da existência, em toda a sua tragicidade, quotidianidade e complexidade. Para tanto, nos parece que a dicotomia entre ser e dever-ser, no fundo, também pode ser superada pois, como argumentaremos no próximo Capítulo, entendemos haver uma dicotomia muito mais relevante que subjaz à discussão acerca do dever-ser (norma) e do ser (fato), com grande relevância na filosofia prática: dicotomia esta consubstanciada no diálogo entre o sernecessário e o ser-possível. 


\section{CAPÍTULO 3. (DEVER-)SER, NECESSIDADE E POSSIBILIDADE ${ }^{37}$}

\subsection{Norma: do dever-ser para o poder-ser}

Em que pesem os argumentos dos defensores do juspositivismo, somos da opinião que, no conjunto das decisões humanas, diária e ininterruptamente tomadas, consideradas em sua individualidade mais própria, não é a lei ${ }^{38}$ aquilo que efetivamente, per se, traça o conduzir humano, muito menos serve como chave de interpretação única para se decifrar o que é jurídico.

Muitas vezes, com efeito, o indivíduo que não tenha sido treinado em nossas escolas jurídicas, ao tomar suas decisões quotidianas, acaba por não ter a mais pálida ideia do que de fato está proposicionalmente disposto na lei estatal, ou mesmo nas cláusulas de simples contratos de locação que tenha de celebrar ou, ainda, na decisão do magistrado que deferiu seu despejo (tecnicistas e esotéricos que soam e são para os leigos).

Entendemos, ao contrário, que o discurso jusfilosófico poderia tentar sobrepujar essa religiosidade normativa, a qual trata a norma jurídica sempre a partir e no âmbito de sua necessidade e de sua pretensa quase-infalibilidade, como se a conduta humana dela dependesse, e não o contrário.

Como visto, sequer podemos afirmar que a norma jurídica, em tese a chave da boa conduta, é sempre linguisticamente inteligível a todos aqueles que fazem parte de uma comunidade estatal, em vista do esoterismo e do tecnicismo que lhe são intrinsicamente afeitos.

Muito menos acaba tal norma por ser sempre existencialmente sentida ${ }^{39}$, o que se torna tanto mais um ataque à pretensa necessidade normativa como pode inclusive fazer com

\footnotetext{
37 Em primeiro lugar, uma ressalva terminológica: para que não haja qualquer dúvida, ao longo desta Dissertação consideramos os termos possibilidade, poder-ser e ser-possível como sinônimos, sendo que a sinonímia não se aplica aos termos potencialidade (virtualidade) ou ser-potência.

${ }^{38}$ Denominação empregada visando a abarcar a norma estatal em si - constituições, leis, decretos, instruções normativas, decisões judiciárias, etc. - e aquelas dela obviamente resultantes - sentenças arbitrais, contratos, acordos de leniência, termos de ajuste de conduta, editais para concessões administrativas, etc.

${ }^{39}$ Quantas pessoas, além de uma pequena parcela dos iniciados, conhece de fato como se efetua (qual é a norma para) um cálculo trabalhista em caso de demissão sem justa causa?
} 
que a análise se choque frontalmente com um dos cânones em tese inatacáveis do direito: a impossibilidade, em quase todas as situações, de se alegar ignorância da lei para o fím de não ver aplicada a sanção eventualmente prevista contra si por sua conduta (ainda nos casos em que a ignorância seja óbvia e comprovada).

Assim sendo, fica difícil aceitarmos como adequadas discussões jusfilosóficas que usam um conceito tal qual o de norma jurídica (cuja existência ou conteúdo, reiteramos, tendem a não ser compartilhados com boa parte do auditório que compõe aquela referida comunidade estatal, da qual em tese igualmente se demanda obediência) como chave de interpretação e de análise para suas conclusões.

Sob nossa perspectiva, estar-se-ia tentando justificar a fórceps o dito 'sistema' jurídico pois sua mônada, aquilo que é usado como seu fundamento originário, nem ao menos seria inteligível para todos aqueles que não fazem parte do círculo dos iniciados, seus quase-sacerdotes-tecnocratas (tecnossacerdotisas e tecnossacerdotes). E pior: muitas vezes referida mônada é inteligível nem ao menos aos iniciados pois, frequentemente, dependem de serem eles também ungidos pela "interpretação autêntica” da norma.

Parece-nos assim que tais teorias tendem a enxergar na ideia da norma jurídica o fundamento de facetas específicas do direito (como sua validade, sua eficácia, sua autoridade, sua técnica, etc.), do direito em si e até mesmo como fundamento das condutas humanas.

A conduta humana, de fato, repetidamente passa a ser pensada apenas no espaço, momentos e movimentos permitidos dentro do binômio (des)obediência-(i)legalidade, em que somente tem 'valor', i.e., somente adquire sentido (muitas vezes até existencialmente falando) se lastreada no fenômeno jurídico.

Há, assim, um claro esvaziamento do humano em prol da técnica. 
Em vista de todas as dificuldades e anfibologias existenciais, entendemos que o conceito de dever-ser/norma, embora um dos $\tau$ ó $\pi 0 \imath$ (topoi $)^{40}$ mais utilizados na jusfilosofia, não é o mais apropriado lugar-comum para (des)construirmos o fenômeno jurídico.

Nossa proposta é a de buscarmos referida (des)construção no conceito de possibilidade, mais especificamente no conceito de possibilidade existencial resultado de uma análise ontológica e fenomenológica do poder-ser.

Tal se dá pois, como já afirmado pelo Professor Nicola Abbagnano, as normas, as regras, sejam jurídicas ou não, podem sim ser consideradas como possibilidades narrativas e, por tanto (sic), existenciais/comportamentais. Normas, neste sentido, não são como necessárias receitas de conduta que se apresentam como compulsórias à humanidade, para sua compulsiva obediência inconteste. Muito menos ensinam o melhor caminho para se conviver em sociedade, conforme o mando do soberano estado.

\section{Com efeito:}

Regole, norme, massime, comandi sono tutte possibilità in questo senso: possibilità alle quali noi riconosciamo un valore speciale e, a volte, una dignità superiore, ma pur sempre possibilità. (ABBAGNANO, 1956, p. 12).

E uma das características mais vívidas desta possibilidade é a sua intrínseca e inarredável possibilidade de vir a não ser, o que nas normas tende a ocorrer não apenas quando há sua transgressão, mas também no caso de serem completamente ignoradas.

Ainda o Professor Abbagnano:

[...], non c'é norma, regola o comando che non possa essere o trasgredita o obbedita: il che vuol dire che ogni norma, regola o comando apre di fronte a noi un'alternativa, che ci consente la scelta. [...] Le regole che dirigono la condotta

\footnotetext{
40 "Quando se trata de fundamentar valores ou hierarquias, ou de reforçar a intensidade da adesão que eles suscitam, pode-se relacioná-los com outros valores ou com outras hierarquias, para consolidá-los, mas podese também recorrer a premissas de ordem muito geral, que qualificaremos com o nome de lugares, os $\tau$ ó $\pi 01$, dos quais derivam os Tópicos [aristotélicos], ou tratados consagrados ao raciocínio dialético." (PERELMAN, Chaïm, et al. Tratado da argumentação. - Tradução de Maria Ermantina Galvão G. Pereira. São Paulo: Martins Fontes, 1996, p. 14, grifos no original).
} 
degli affari sono semplicemente quelle che definiscono la possibilità di ottenere resultati desiderabili; [...]. Un precetto morale o religioso, per es. un comandamento del Decalogo, no fa altro che indicare un possibilità d'azione o di comportamento che, con buone ragioni, si ritiene superiore alle altre. 'Non ammazzare', 'non rubare', sono precetti indubbiamente fuori questione, ma che non fanno altro che indicate certe azioni possibili. Difatti, non rendono impossibili le azioni contrarie, che tragrediscono i precetti stessi. La loro trasgressione, anzi, è purtruppo continua e quotidiana; [...]. (ABBAGNANO, 1956, p. 12).

De qualquer maneira, não há motivo para que o deslocamento do dever-ser para o poder-ser ocorra de maneira abrupta pois há outros elementos, capturáveis nas discussões que constituem a tradição filosófica, capazes de trazer mais vida, dramaticidade e materialidade à própria ideia de poder-ser.

Com efeito, tal deslocamento reclama que se presentifique um outro e mais antigo debate. Pois, da mesma forma pela qual aparentemente as normas são/existem, as possibilidades do mesmo modo aparentam ser, estarem-aí.

E daí, mais uma vez tem-se que fazer a pergunta: o que é ser?

\subsection{O ser histórico}

Como a história da metafísica e da lógica ocidental evidencia, podemos encaminhar o debate em torno da questão “o que é o ser?" para caminhos os mais diversos e imaginativos possíveis, o que pode redundar inclusive em uma tergiversação pedantemente escolástica, a qual é capaz de piorar ainda mais quando se tenciona trazer discussões tais ontológicofilosóficas para o mundo da teoria geral do direito e da sua respectiva filosofia.

Ainda assim, um mínimo precisa ser trazido para tornar mais claros os pontos abaixo, até mesmo pois estamos aqui tratando da Guilhotina de Hume que, como já mencionamos, usualmente é vista como um debate entre o dever-ser (Sollen) e o ser (Sein) (debate este que pretendemos superar). 
Tradicional e historicamente, existem dois usos fundamentais para o termo "ser": (a) o uso predicativo; e (b) o uso existencial ${ }^{41}$. Pelo primeiro, em suma, dizemos "Tício é um bom jurista", em que há a predicação de algo (no exemplo, "bom jurista") a um sujeito (o desde sempre mencionado "Tício”).

Apenas para fins propedêuticos, normalmente o uso predicativo é interpretado sob três perspectivas diferentes: (i) a da doutrina da inerência (o ser significaria pertencimento/pertença/compartilhamento essencial, em que algo é inerente a outro ${ }^{42}$ ); (ii) a da doutrina da identidade (ou suposição, pela qual "a cópula significa identidade do objeto ao qual o sujeito e o predicado da proposição se referem ou no lugar do qual estão" (ABBAGNANO, 2007, p. 1044); e (iii) a da doutrina da relação, que pode ser subdividida em duas: (iii.a) relação subjetiva, pela qual a predicação é mero ato ou operação do sujeito pensante, sendo que por este ponto de vista "a proposição apresenta-se como juízo e começa a ter esse nome porque juízo é exatamente o ato com que o espírito escolhe ou decide" (ABBAGNANO, 2007, p. 1045, grifos no original); ou (iii.b) relação objetiva, de criação dos lógicos e matemáticos dos séculos XIX e XX (De Morgan, Boole, Schröder, Peirce), pela qual a cópula (ser) é entendida como sendo "a mesma em todas as formas proposicionais, não porque sua natureza esteja expressa na proposição, mas porque é estabelecida por convenção. A cópula pode então expressar uma relação qualquer" (ABBAGNANO, 2007, p. 1046). Trata-se do uso do ser como veículo instrumental para a própria matemática e para a lógica, segundo sua roupagem mais contemporânea, isto é, entendidas em seu sentido mais formal ${ }^{43}$.

Entretanto, a mera análise predicativo-proposicional do ser não nos parece alcançar o ser em sua propriedade (radicalidade) mais autêntica, muito menos para fins de determinação do ser-jurídico.

\footnotetext{
${ }^{41}$ ABBAGNANO, Nicola. Dicionário de filosofia. Tradução da $1^{\mathrm{a}}$ edição brasileira coordenada e revista por Alfredo Bossi; revisão da tradução e tradução dos novos textos por Ivone Castilho Benedetti. - $5^{\text {a }}$ edição. São Paulo: Martins Fontes, 2007, p. 1043.

42 "As características fundamentais desse conceito do ser predicativo são: $1^{\circ}$ sua redução a um tipo único de relação, qualificada como pertença ou inerência; $2^{\circ}$ o privilégio concedido à forma necessária dessa relação, ou seja, à forma como essa relação intercede entre substância e essência. Essas características são mantida pela doutrina em exame ao longo de toda a sua história, que é longuíssima." (ABBAGNANO, 2007, p. 1044).

43 "A lógica contemporânea adotou o conceito matemático de função; emprega o símbolo matemático de função, $f(x)$, para indicar proposições da forma "a baleia é um mamífero", em que o símbolo $x$ representa o argumento, o sujeito do qual se fala (a baleia ou outro mamífero qualquer), e $f$ corresponde à propriedade que se lhe atribui (mamífero)." (ABBAGNANO, 2007, p. 549).
} 
De fato, nossa intenção ao longo dessa Dissertação é fazer com que percorramos caminhos argumentativos em que o fenômeno jurídico (o ser-jurídico) está sendo analisado, esperamos de maneira minimamente adequada, por meio de discussões visando a um melhor entendimento de suas possibilidades existenciais (e não apenas aquelas de caráter deontológico-proposicionais, ou meramente lógico-formais).

Por estes caminhos, entendemos que aumenta a possibilidade de se buscar um tipo de verdade do fenômeno jurídico lastreada não apenas na noção de dever-ser, em que se tende a fazer uma correspondência entre o mundo fático (a conduta) e um algo (a norma) que é humano mas simultânea e aparentemente transcendental, não importando que este algo seja autonomamente legiferante (como o dever-ser moral kantiano consubstanciado na ideia de imperativo categórico, por exemplo) ou na medida em que este algo seja utilizado por uma assembleia de homens como mônada pela qual haverá um processo legiferante, em que novas mônadas serão criadas.

Para tanto, entendemos salutar utilizarmos o termo "ser" para além dos seus usos predicativos, sem deles olvidar. Assim, temos que tomar pela mão o segundo uso fundamental do termo "ser", pelo qual dizemos que algo "é", no sentido de existir ("a rosa é”, “Tício é”, “o direito é”), ou seja, o uso existencial do termo "ser”: $\underline{\text { o ser assim entendido }}$ como existência.

Tal caminho interpretativo visará a buscar e trabalhar o fenômeno jurídico como uma possibilidade existencial de (des)velamento do ético, do poder-ser do humano e de cada humano, nas ininterruptas, quotidianas e trágicas decisões tomadas ao longo da vida. Neste diapasão, a norma, seja ela de que tipo for (jurídica, ética, religiosa, comunitária, etc.), será analisada de forma a se considerá-la como não apta, per se, para ser apresentada como fundamento último de todo o sistema ${ }^{44}$.

\footnotetext{
${ }^{44}$ Em que pese a possibilidade de a norma ser sim tomada como referência proposicional, na medida em que é parte de uma narrativa existencial daquele que tem que tomar a decisão.
} 
Mas, ainda que se busque com-partilhar (sic) os momentos-movimentos do ser ao longo da história, como existência, estamos com Eco quando este afirma, lastreado na doutrina de Aubenque (e por óbvio do próprio Heidegger), que:

[...] o problema do ser (a resposta à pergunta “o que é o ser?”) é o menos natural de todos os problemas, aquele que o senso comum jamais se interroga. [...] A tal ponto que a tradição posterior a Aristóteles não perguntou, removeu-o por assim dizer, e talvez a isto se deva o fato já legendário de que o texto da Metafísica tenha desaparecido para reaparecer no século I a.C. (ECO, 1998, p. 22)

E Eco aprofunda sua perplexidade ao afirmar que:

\begin{abstract}
O ser não é um problema de senso comum (ou melhor, o senso comum não se o coloca como um problema) porque é a própria condição do senso comum. No início do De Veritate (1.1), São Tomás diz: "Illud autem quod primum intellectus concipit quasi notissimum, et in quo omnes conceptiones resolvit, est ens." Que algo existe é a primeira coisa que o nosso intelecto concebe como a mais notória e evidente, e todo o resto vem depois. Ou melhor, não poderíamos pensar senão partindo do princípio (implícito) de que estamos pensando algo. O ser é o horizonte, ou o líquido amniótico, em que naturalmente se move o nosso pensamento - [...]. (ECO, 1998, p. 23).
\end{abstract}

Nesta mesma linha de pensamento, em sua magnum opus Heidegger afirma que a filosofia ocidental simplesmente deixou operar um "esquecimento do ser", e da originalidade que tal problema de fato se nos apresenta e representa:

No solo da arrancada grega para interpretar o ser, formou-se um dogma que não apenas declara supérflua a questão sobre o sentido de ser, como lhe sanciona a falta. Pois se diz: "ser" é o conceito mais universal e mais vazio. Como tal, resiste a toda tentativa de definição. Esse conceito mais universal e, por isso, indefinível, prescinde de definição. Todo mundo o emprega constantemente e também compreende o que ele, cada vez, pretende designar. Assim o que, encoberto, inquietava o filosofar antigo e se mantinha inquietante, transformou-se em evidência meridiana, a ponto de acusar quem ainda levantasse a questão de cometer um erro metodológico. (HEIDEGGER, 2012, p. 37). 
Mas de onde poderíamos nos lançar (projetar) para analisar o que seria o ser, sob o viés existencial da pergunta, e mais especificamente o ser-jurídico?

Sugerimos que nos lancemos a partir da própria história da metafísica ocidental, não em seu caráter suprassensível e teológico (que contestamos com veemência), mas sim

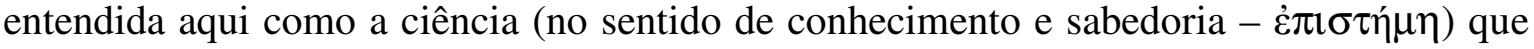
"considera o ser enquanto ser e as propriedades que lhe competem enquanto tal", na linha de um dos fragmentos filosóficos mais transcritos e debatidos em todos os tempos, contido no Livro 4 (Г) 1003a, linhas 20 e 21, da Metafísica ${ }^{45}$ de Aristóteles:

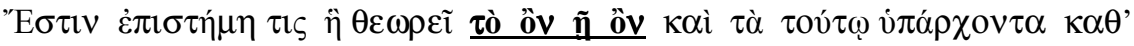

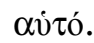

Existe uma ciência que considera o ser enquanto ser e as propriedades que lhe competem enquanto tal. (ARISTÓTELES, 2013, p. 130-131, grifos nossos)
}

Deixando por um momento de lado as respostas dadas pelo próprio Aristóteles acerca dos desdobramentos aplicáveis a este conhecimento do "ser enquanto ser" (ou melhor, dos "sendos enquanto sendos"/"essentes enquanto essentes", à medida que o famoso " $\tau$ ò ôv" ${ }^{46}$ gramaticalmente nada mais é do que a forma nominal - isto é, substantivada - da conjugação na terceira pessoa do neutro plural do particípio presente do verbo ser - $\varepsilon i \mu i^{47}$, levando-se em consideração que em grego há apenas duas formas nominais para os verbos, o infinitivo e o particípio, diferentemente do português que, na linha do geralmente aplicado a todas as línguas românicas, possui três formas nominais, quais sejam, o infinitivo, o particípio e o gerúndio ${ }^{48}$ ), entendemos ser positivo auscultarmos às raízes mais profundas e míticas acerca da questão, o que retornará nosso debate aos primeiros cantos e narrativas acerca do ser.

\footnotetext{
${ }^{45}$ ARISTÓTELES. Metafísica: volume II; texto grego com tradução de Giovanni Reale. Tradução de Marcelo Perine. - $3^{\text {a }}$ ed. São Paulo: Edições Loyola, 2013.

${ }^{46}$ De onde adviria inclusive a palavra "ontologia".

${ }^{47}$ RAGON, Elói. Gramática grega. - Tradução de Cecília Bartalotti. São Paulo: Odysseus Editora, 2011, p. 78.

${ }^{48}$ Cf. BECHARA, 2009, p. 224.
} 


\subsection{O ser e a necessidade}

\subsubsection{Rufar mítico do ser-necessário}

Sob o ponto de vista da filosofia ocidental, o debate em torno do ser diz respeito a uma busca por respostas acerca de discussões que, em suma, tencionavam encontrar a causa, a estrutura e o fundamento último das coisas, mas de maneira a necessariamente a tudo fundar e explicar.

Referidas discussões acabaram por serem consolidadas nas narrativas criadas em torno deste algo denominado "ser", tendo elas florescido no âmbito mesmo dos primeiros pensadores e bardos helênicos que buscavam resolver o problema dito cosmológico, pela qual tencionava-se aprofundar o "problema de perseguir a unidade que garante a ordem do mundo e a possibilidade do conhecimento humano"49.

Nessa linha de pensamento, entendemos salutar mencionarmos rapidamente alguns de tais pensadores cosmológicos da Grécia antiga sem diferenciar, ao menos não de maneira totalmente estanque, os filósofos dos bardos, pois nos parece importante escutar o originário abismo, o Ur-sprung Ab-grund narrativo do qual ambos buscam elementos em sua tentativa de compreensão e justificação do mundo que lhes cercava e que, muitas vezes, parecia transparecer uniformidades e unidades reconhecíveis ao pensamento, e não apenas guerra, dor, quebra de expectativas e desordem.

Envolto nas constantes e estuporosas efemérides humanas, buscava-se uma tábua que possibilitasse algum tipo de cálculo seguro de tais efemérides, tábua esta que ser-lhe-ia prática e, sobretudo, de alguma maneira reconfortante.

Nesta linha, podemos mencionar um dos textos mais famosos da Antiguidade Clássica, a saber, a Teogonia $(\Theta \varepsilon o \gamma o v i ́ \alpha)^{50}$ de Hesíodo, "o mais antigo documento da cosmologia mítica entre os Gregos" (ABBAGNANO, 2006, p. 20), no qual seu autor

\footnotetext{
${ }^{49}$ ABBAGNANO, Nicola. História da filosofia. Tradução de António Borges Coelho et al. - Vol. I - Lisboa: Editorial Presença. $7^{\mathrm{a}}$ ed., 2006, p. 23.

${ }^{50}$ HESÍODO. Teogonia. Tradução de Christian Werner. - São Paulo: Hedra, 2013.
} 
registrou, de maneira quase enciclopédica, boa parte da narrativa cosmogônica que circulava por entre os helênicos em 800 a.C./700 a.C.

A título de mera contextualização histórica, e considerando o poema como elaborado por volta de 700 a.C., temos que ele apareceu logo após o fim do período em que teriam ocorrido as 'invasões dóricas', mas que hoje é comumente chamado de a "Idade das Trevas da Grécia Antiga”. Há diversos elementos históricos que comprovam ter havido neste período o colapso das civilizações cretense e micênica, além de toda a base comercial fundada nas estruturas sociais estabelecidas na Idade do Bronze grega - além de várias outras também de origem indo-europeia.

O que quer que tenha ocorrido, fez com que o poder político em toda a península balcânica fosse descentralizado, contra a tendência verificada na Idade do Bronze grega, propiciando inclusive assim a criação das próprias cidades-estados helênicas ( $\pi \mathrm{o} \lambda \mathrm{\iota} \varsigma)$.

Sobressai, desta maneira, o trabalho de Hesíodo exatamente por amalgamar boa parte das diversas e, muitas vezes, conflitantes visões cosmogônicas que circulavam à época, de um modo que será marcante para toda a cultura helênica vindoura: um trabalho que visa à universalização tanto dos problemas como de suas soluções, buscando os princípios últimos e as causas primeiras que levaram o homem e a própria natureza a ser o que eles são (e como são).

De fato, em uma das histórias mais recontadas durante a história humana, segundo Hesíodo primeiramente teria surgido $\mathrm{X} \alpha \mathrm{c} \varsigma$ (o Caos/Abismo), enquanto amplo vazio

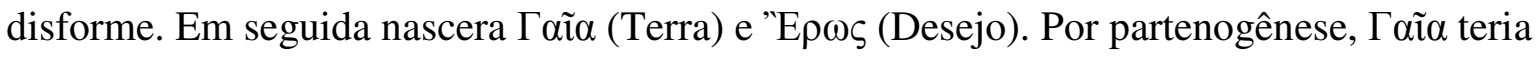

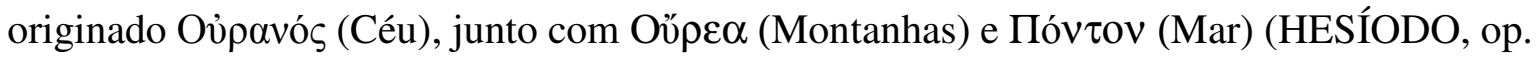
cit., p. 39).

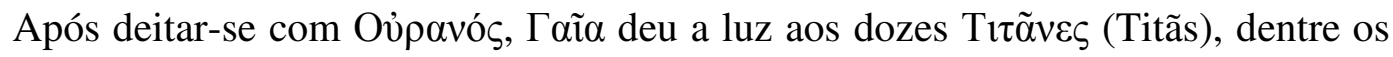
quais se encontrava $\Theta \varepsilon ́ \mu ı \varsigma$, que na sequência apresentada pelo próprio Hesíodo assim teriam

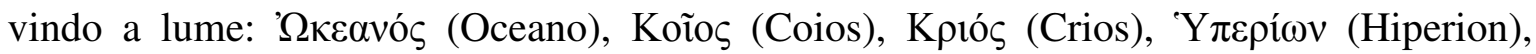

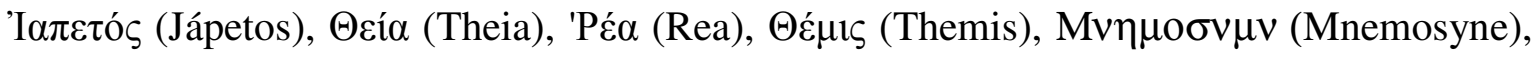

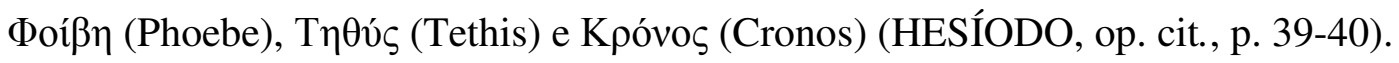


A partir destes titãs, surge todo o Panteão Olímpico a que estamos mais acostumados (Zeus, Apolo, Hera, Atena, etc.), seja por partenogênese, por núpcias reconhecidas ou adultério.

É de se notar que Hesíodo, ao trabalhar com a personificação helênica dos deuses, característica de sua religião, cria um Panteão de deidades que lida com questões relacionadas não apenas à estrutura física do seu mundo (a terra, os mares, o céu, as montanhas, o frio etc.), mas também à pretensa causa original de sentimentos mais comunais, políticos e imateriais como o desejo, a justiça, a memória, etc.

A partir desta genealogia e dos acontecimentos decorrentes do nascimento deste Panteão, Hesíodo tenciona, no fundo, apresentar um mapa, um caminho narrativo pelo qual ele tenta entender melhor o motivo, a razão, o fundamento pelo qual as coisas são como e pelo o que são, e como tais coisas poderiam ter relação com a própria conduta humana.

Por exemplo, seria a justiça importante na ordem celestial? Se sim, de onde adviria o seu poder? Qual o seu lugar no sagrado?

Buscando criar (recontar) o mapa narrativo de sua época, Hesíodo menciona logo no início de sua genealogia que uma das personificações/manifestações da justiça, qual seja, a deusa $\Theta \varepsilon ́ \mu ı \varsigma$ (Themis), cujo nome muitas vezes é traduzido como Norma ou Lei Divina,

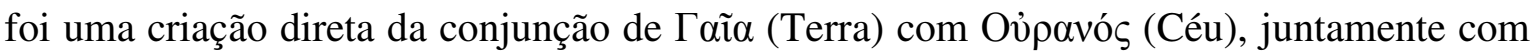
os outros onze titãs.

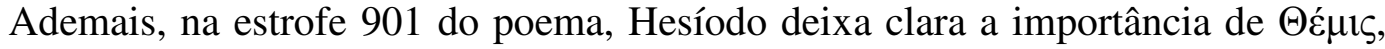
segunda esposa de Zev́c, ao afirmar que:

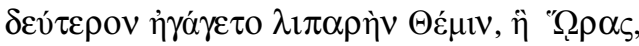

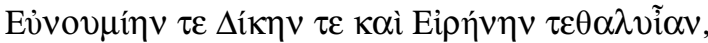

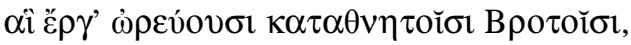

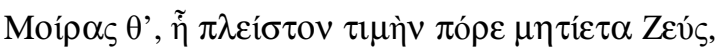

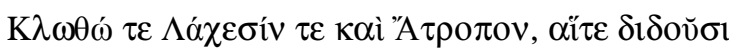

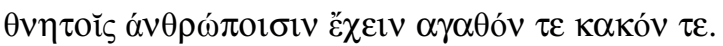


A segunda fez conduzir a luzidia Norma, mãe das Estações,

Decência, Justiça e a luxuriante Paz,

elas que zelam pelos trabalhos dos homens mortais,

e as Moiras, a quem deu suma honraria o astuto Zeus,

Fiandeira, Sorteadora e Inflexível, que concedem

aos homens mortais terem bens e males. (HESÍODO, op. cit., p. 92-93)

Curioso notarmos que a deusa $\Delta \mathrm{\imath} \kappa$, filha de Themis, faz parte de um grupo de deidades (as " $\Omega \rho \alpha \varsigma$ - Horas) que “zelam pelos trabalhos dos homens mortais", presidindo para tanto as estações do ano. Destarte, originariamente a deusa $\Delta \mathrm{\imath} \kappa \eta$ (Justiça), em conjunto

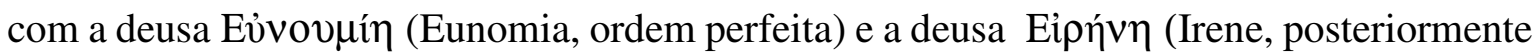
denominada de Pax pelos romanos) foram concebidas como mantenedoras da ordem natural, uniforme e eterna das coisas ( $\varphi v ́ \sigma ı \zeta)$ enquanto relacionadas com o ser humano, e não como protetoras/aplicadoras das convenções socialmente estabelecidas pelos membros da polis (vouór).

Enfim, por meio de sua poesia, Hesíodo na realidade já prenunciava aquele tipo de tentativa que mais tarde daria corpo às especulações filosóficas (dos helênicos à Era Contemporânea), acerca da unidade do mundo e a busca de sua $\alpha \rho \chi \eta ́$ (causa e princípios últimos), em que se lutou por enxergar a estrutura, final e necessária, que regularia e justificaria o mundo (e suas incongruências).

Referida busca pela unidade, pelo fundamento último que necessariamente a tudo regeria, iniciou-se na Grécia Antiga em pensadores muito originários, os chamados présocráticos.

\subsubsection{Narrativas e angústias}

Conforme magistério de Abbagnano:

O escopo da filosofia pré-socrática é o de perseguir e reconhecer, para lá das aparências múltiplas e continuamente mutáveis da natureza, a unidade que faz da própria natureza um mundo: a única substância que constitui o seu ser, a única lei que regula o seu devir. (ABBAGNANO, 2006, p. 27). 
De fato, podemos mencionar neste sentido Heráclito de Éfeso, filósofo que viveu por volta de 535 a.C. a aproximadamente 475 a.C., quase três séculos após o surgimento da Teogonia.

Analisando-se os fragmentos de Heráclito que sobreviveram às intempéries, há alguns que identificamos que comprovam a incorporação, ainda que crítica (fragmento 57 DK), da narrativa mitológica anunciada por Hesíodo aos textos do Efésio ${ }^{51}$ :

\section{FRAGMENTO 94}

"H

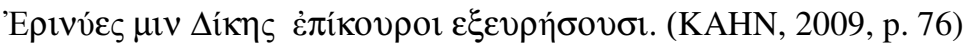

$\mathrm{O}$ sol não transgredirá suas medidas. Se o fizer,

as Fúrias e a Justiça alcançá-lo-ão. ${ }^{52}$

\section{FRAGMENTO 57}

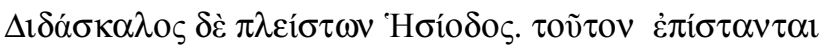

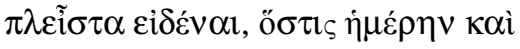

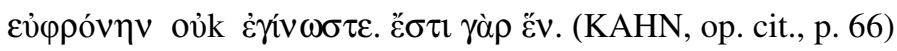

A maioria aprendeu com Hesíodo. Ele é reconhecido como o que mais conhece, ele que não reconheceu que dia e noite são de fato unos. ${ }^{53}$

\section{FRAGMENTO 114}

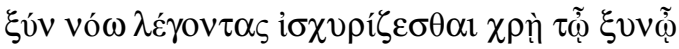

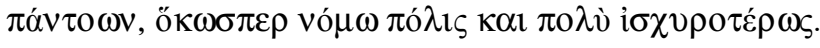

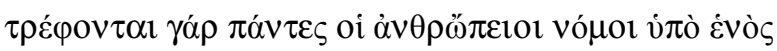

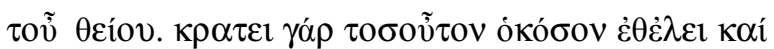

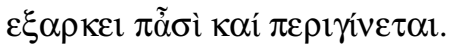

Os que falam com inteligência devem apoiar-se no que é comum a todos, assim como uma cidade se apoia na sua lei, e ainda mais firmemente. Pois todas as leis humanas nutrem-se de uma só divina. Esta prevalece segundo a sua vontade e basta para todos e ainda sobra. (KAHN, op. cit., p. 70)

\footnotetext{
${ }^{51}$ É curioso notarmos que, salvo uma pesquisa mais detalhada de outros textos a que eventualmente não tivemos acesso durante a elaboração desta Dissertação, Heráclito não faz qualquer menção à Themis, o que aparentemente visa a apontar para um robustecimento da deusa Dike enquanto uma das mantenedoras da ordem junto aos homens nas narrativas que circulavam à sua época.

${ }^{52}$ Tradução livre por nós feita a partir de uma leitura conjunta de KAHN, op. cit., p. 66 e de HERÁCLITO, Fragments. - Tradução por Brooks Haxton. New York: Penguin, 2001, p. 18.

${ }^{53}$ Tradução livre por nós feita a partir de uma leitura conjunta de KAHN. op. cit., p. 66 e de HERÁCLITO, op. cit., p. 22 (grifos nossos).
} 


\section{FRAGMENTO 80}

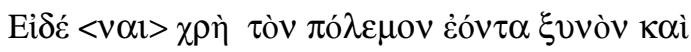

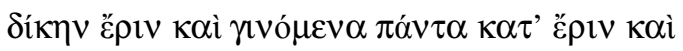
$\chi \rho \varepsilon \omega ́ \mu \varepsilon v \alpha$. (KAHN, op. cit., p. 91, grifos nossos )

Deve-se compreender que a guerra é coisa comum, e que a Justiça e a Discórdia são unas, e que todas as coisas vêm a ser de acordo com a Discórdia. ${ }^{54}$

\section{FRAGMENTO 28B}

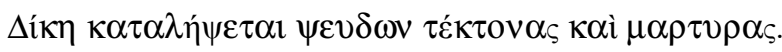

A Justiça alcançará os que inventam mentiras e os que juram por elas. (KAHN, op. cit., p. 93).

É possível notarmos na narrativa de Heráclito a constante presença da incongruência, da luta, da transgressão, do oposto, do devir, pelos quais a existência, com tudo o que traz de positivo e negativo, tende a não ser compreendida a partir de um plano estável, predeterminado, único e uniforme ${ }^{55}$.

De fato, com maior atenção à constitutividade sempre-desde-já-presente do devir, há outros fragmentos que também tendem a reforçar a percepção que, em Heráclito, o (in)constante ir e vir da história e da humanidade, que afronta totalmente a ideia positivista do eterno, constante e absoluto progresso, é aceito, e não combatido, e poderia no final ser entendido como um elemento deveras constitutivo da própria humanidade.

Nestes fragmentos, alguns recontados inúmeras vezes ao longo da história da filosofia ocidental, Heráclito toca exatamente no caráter fugidio da existência e das decisões humanas:

\section{FRAGMENTO 10}

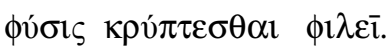

A natureza ama ocultar-se. (KAHN, op. cit., p. 63.)

\footnotetext{
${ }^{54}$ Tradução livre por nós feita a partir de uma leitura conjunta de KAHN, op. cit., p. 91 e de HERÁCLITO, op. cit., p. 40 .

${ }^{55}$ Ainda assim, ele aparenta entender que a conduta, seja humana ou divina, acaba sempre por estar imbuída de uma necessidade, ainda que esta seja percebida apenas em função do seu caráter sancionatório.
} 


\section{FRAGMENTO 103}

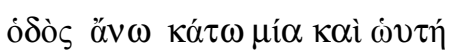

O caminho para cima e para baixo é um e o mesmo. (KAHN, op. cit., p. 98).

\section{FRAGMENTO 50}

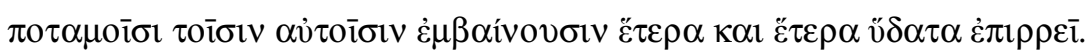
Ao entrarem nos mesmos rios, outras e ainda outras [são] as águas [que] fluem sobre eles. (KAHN, op. cit., p. 79)

\section{FRAGMENTO 51}

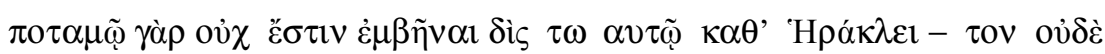

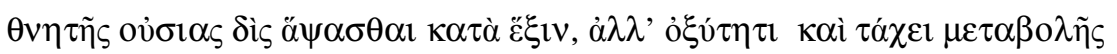

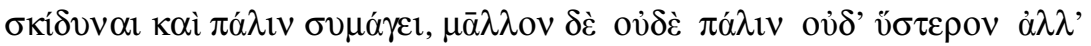

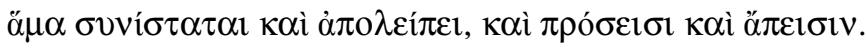

[Segundo Heráclito, u]m não pode entrar duas vezes no mesmo rio, nem apreender qualquer substância em condição estável, mas dispersa e de novo reúne; forma e dissolve, e aproxima e afasta. (KAHN, op. cit., p. 79).

Assim, com base na narrativa recontada pelos fragmentos acima, temos que:

(i) nem ao menos o sol poderia transgredir suas normas, sua métrica $(\mu \varepsilon ́ \tau \rho \alpha)$, sob pena de as Fúrias e a própria Justiça necessariamente imporem as punições que tal ato deveria trazer se, de alguma forma, conduzido (fragmento 94);

(ii) a necessária sobreposição da lei divina à lei humana, que, em última instância, seria inclusive a base para a unidade política, fundada na lei (fragmento 114), visto que muito mais estável;

(iii) a necessidade de a discórdia, a oposição e a guerra serem, em sua intrínseca conflituosidade, a principal mantenedora da realidade e unidade sociais (fragmento 80), sem esquecer da sempre presente necessidade de sanção pela transgressão normativa (fragmento 28b); e 
(iv) a dificuldade de, na imitação, tomar decisões baseadas no mesmo fundamento, já que nem ao menos os rios são sempre confiavelmente os mesmos (fragmento 50).

Nicola Abbagnano leciona em sentido análogo ao afirmar que:

A grande descoberta de Heráclito é, pois, que a unidade do princípio criador não é uma unidade idêntica e não excluí a luta, a discórdia, a oposição. Para compreender a lei suprema do ser, o logos que constitui e governa, é necessário unir o completo e o incompleto, o concorde e o discorde, o harmónico e o dissonante (fr. 10), e dar-se conta de que de todos os opostos brota a unidade e da unidade saem os opostos. "É a mesma coisa o vivo e o morto, o acordado e o dormente, o jovem e o velho: pois que cada um destes opostos, transformando-se, é o primeiro" (fr. 88). Como na circunferência todo o ponto é ao mesmo tempo princípio e fim, como o mesmo caminho pode ser percorrido para cima e para baixo (fr. 103, 60), assim todo o contraste supõe uma unidade que constitui o significado vital e racional do próprio contraste. "O que é oposto une-se e o que diverge conjuga-se". "A luta é a regra do mundo e a guerra é comum geradora e senhora de todas as coisas". (ABBAGNANO, 2006, p. 35).

Contudo, já à época de Heráclito, este discurso pró-devir deve ter causado certo estupor.

De fato, como admitir que o vivo e o morto são o mesmo? Como admitir que são unos a criança e o defunto, se claramente aparentam não o ser, vistas suas claras diferenças existenciais? Se tudo é oposição e mudança, como alcançar algum tipo de certeza? Onde fica o conforto de se saber o caminho a ser tomado, sempre e necessariamente? A guerra, e não o amor ou os deuses (ou a certeza científica, como diriam os positivistas no futuro), é a mãe que a tudo gerou e que a todos mantém? Justiça e injustiça seriam, nesta toada, a mesma coisa?

Os riscos verdadeiramente poderiam ser ainda maiores.

Como não afrontar os anseios (divinos, imperiais ou patriarcais), obedecendo de pronto e cegamente a seus preceitos, se tudo é devir e mutável? Afinal, se tudo é devir, as leis também têm de sê-lo, e os homens não teriam deste modo sido lançados para um terreno 
à beira de uma perigosa heresia, pela qual os próprios comandos divinos, ou aqueles emanados dos seus representantes mundanos, passariam a ser constitutivamente inconstantes, volúveis e impossíveis de serem conhecidos (e, quiçá, impossíveis de serem obedecidos)?

Como decidir, em um ambiente tão fluido e, possivelmente, arriscado e incerto?

Forçoso reconhecermos que esta fluidez da existência, em que os pilares usados pela humanidade para o conduzir-se mudam de tonalidade e buscam fundamentos outros a todo átimo, pode redundar sim em uma paralisia angustiante, em que o medo do outro possível tende inclusive a limitar tomar-se qualquer tipo de decisão ${ }^{56}$.

Tal angústia, no pensamento de Kierkegaard (no século XIX), e conforme lecionado por Abbagnano:

[...] non è paura nel senso comune del termine, perchè la paura è sempre suggerita da um pericolo preciso, riconoscibile. Essa è soltanto "il sentimento del possibile". È cioè il sentimento che accompagna la considerazione dell'aspetto negativo e nullificante di tutte le possibilità che ci sono offerte [...]. (ABBAGNANO, 1956, p. 16).

Assim, em face do devir, da mudança constitutivamente desde-sempre-já-aqui presente, nos parece que para muitos surge uma certa angústia, um sentimento de apreensão e insegurança, que precisaria ser, para dizer o mínimo, afastado. Para outros, faria parte da existência, sem que necessariamente fosse-lhe afixada qualquer pecha imediatamente negativista.

Uma resposta narrativo-filosófica observada já ao tempo de Heráclito, consubstanciada exemplificativamente na escola eleática, foi simples e direta: negar o devir, com unhas e dentes.

\footnotetext{
${ }^{56}$ Modernamente, o filósofo Kierkegaard ressaltou muito bem o caráter negativo e paralisante que a possível falta de uma "pedra fundamental", de um caminho a bem seguir predeterminado, pode trazer. Abbagnano afirma que "Kierkegaard descobre e acentua, com uma energia até então nunca alcançada, o aspecto negativo de toda a possibilidade que entra na constituição da existência humana. Com efeito, todas as possibilidades além de serem possibilidades-de-sim são também possibilidades-de-não: implicam a nulidade possível daquilo que é possível, por conseguinte a ameaça do nada." (ABBAGNANO, 2000a, p. 155-156)
} 
Segundo antiga tradição (narrativa), reproduzida por Aristóteles:

Outros filósofos sustentaram que o universo é uma realidade única, [...].

Parmênides parece ter entendido o Um segundo a forma, Melisso segundo a matéria [...]. Xenófanes afirmou antes deles a unidade do todo (diz-se, com efeito, que Parmênides foi seu discípulo), mas não oferece nenhum esclarecimento e não parece ter compreendido a natureza nem de uma de outra dessas causas, mas estendendo sua consideração a todo o universo, afirma que o Um é Deus.

Para a pesquisa que estamos desenvolvendo, como dissemos, podemos deixar de lado dois desses filósofos, Xenófanes e Melisso, por serem suas concepções um tanto grosseiras; Parmênides, ao contrário, parece raciocinar com mais perspicácia. Por considerar que além do ser não existe o não ser, necessariamente deve crer que o ser é um e nada mais [...] Entretanto, forçado a levar em conta os fenômenos, e supondo que o um é segundo a razão, enquanto que o múltiplo é segundo os sentidos, também ele afirma duas causas e dois princípios: o quente e o frio, quer dizer, o fogo e a terra; atribuindo ao quente o estatuto do ser e ao frio o do não ser. (ARISTÓTELES, 2013, p. 31-33).

Apesar das críticas que autores contemporâneos fazem à correção histórica desta famosa passagem da Metafísica (fragmento 986b, linhas 11-32 e fragmento 987a, linhas 1$3)^{5758}$, escrita pelo Estagira quase dois séculos após a morte de Parmênides, este efetivamente declarara que o único caminho que os homens poderiam autenticamente tomar em suas decisões seria aquele trilhado pelo ser, nunca pelo não ser, visto que o ser não surgiria do nada, não pereceria, seria único, indestrutível, imóvel e perfeito ${ }^{59}$.

\footnotetext{
${ }^{57}$ Nicola Abbagnano afirma que "os testemunhos de Platão (Sof., 242d) e de Aristóteles (Met., I 5, 986b, 21)" apontam para uma interpretação no sentido de que a escola eleática fora iniciada por Xenófanes de Colófon, $o$ qual "teria sido o primeiro a afirmar a unidade do ser", muito embora esta interpretação seja "bastante improvável" à medida que o ponto de partida de Xenófanes é uma crítica decidida "contra o antropomorfismo religioso, tal como se apresenta nas crenças comuns dos Gregos e ainda como se acha em Homero e em Hesíodo" (ABBAGNANO, 2006, p. 43-44). Para Xenófanes, ainda segundo Abbagnano, haveria uma única divindade que "identifica-se com o universo, é um deus-tudo, e tem o atributo da eternidade: nasce e não morre e é sempre a mesma. Com efeito, se nascesse isso significaria que antes não era; o que não é, não pode nascer nem fazer nascer coisa nenhuma." (ABBAGNANO, 2006, p. 43-44).

58 “[...] não é exato, do ponto de vista histórico, que Parmênides falasse do um segundo a razão

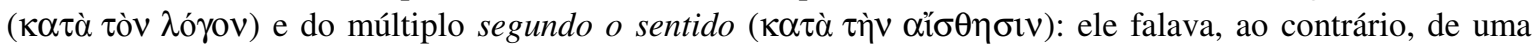

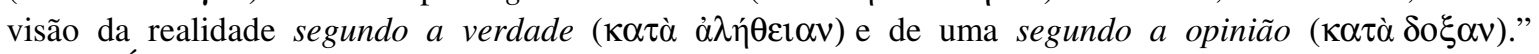
(ARISTÓTELES, 2013, p. 42-43).

${ }^{59}$ Conforme o fragmento 8 (DK), que segue:

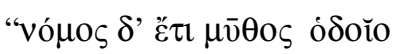

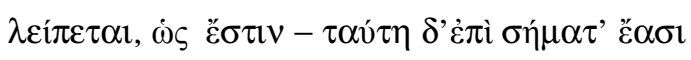

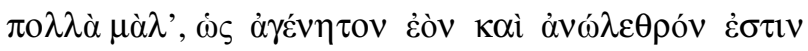


Este "único caminho", o ser-necessário, a verdade inconteste, utilizada pelos homens ao tomar suas decisões quotidianas:

[...] não pode [para Parmênides] ser seguido senão pela razão: uma vez que os sentidos, pelo contrário, se detêm na aparência e pretendem testemunhar-nos o nascer, o perecer, o mudar das coisas, ou seja, ao mesmo tempo o seu ser e o seu não ser. (ABBAGNANO, 2006, p. 46)

Historicamente dois fragmentos foram e continuam sendo narrativamente transmitidos e recontados para consolidar este pensamento:

\section{FRAGMENTO 3}

[...] The one, that a thing is, and that it is not for not being, is the journey of persuasion,

for persuasion attends on reality; the other, that a thing is not, and that it must needs not be, this I tell you is a path wholly without report, for you can neither know what is not (for it is impossible) nor tell of it.

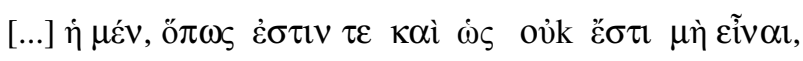

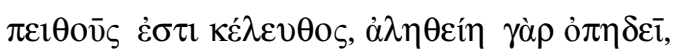

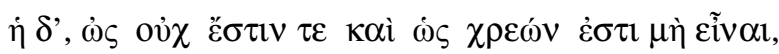

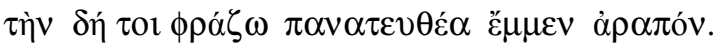

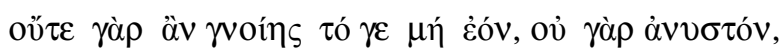

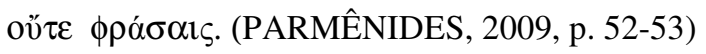

\section{FRAGMENTO 4}

$[\ldots]$ for the same thing is for conceiving as is for being.

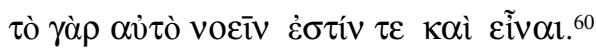

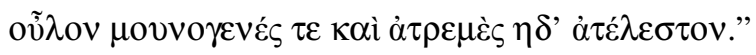

PARMÊNIDES, The fragments of Parmenides, by A.H.Coxon. - Tradução de Richard McKirahan. Las Vegas: Parmenides Publishing/A.H. Coxon 2009, p. 65. Na página 64, o tradutor apresenta a seguinte versão para a língua inglesa:

"Only one story of the way is still left: that a thing is. On this way there are very many signs: that Being is ungenerated and imperishable, entire, unique, unmoved and perfect.")

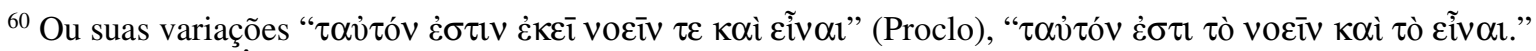
(Platão) (PARMÊNIDES, 2009, p. 54-55). 
Mas é no fragmento 8 (da linha 7 à linha 18) o local em que podemos buscar o excerto que possui elementos que solidificam a posição que estamos tentando aclarar de fato:

\section{FRAGMENTO 8}

[...] I shall not let you say or conceive, 'from Not-being', for it cannot be said or conceived that anything is not; and then what necessity in fact could have urged it to begin and spring up later or before from Nothing? Thus it must either be entirely or not be at all. Nor will the strength of conviction ever impel anything to come to be alongside it from Not-being. Therefore justice did not loosen it in her fetters and move it either to come to be or to be perishing but holds it fast, and the decision regarding these things depends on that of the issue, is or is not. Now it has been decided, as was necessary, to leave one way unconceived and nameless, since it is not a real way, and for the other to be a way and authentic.

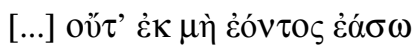

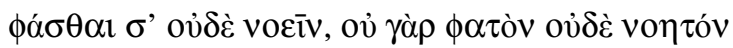

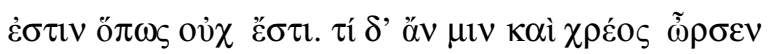

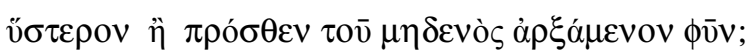

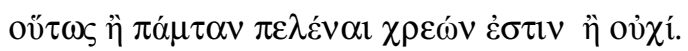

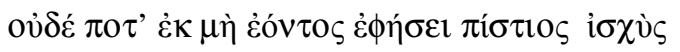

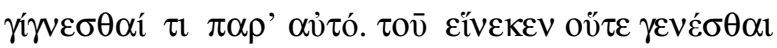

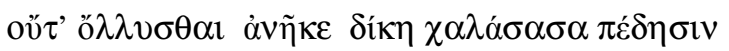

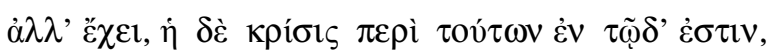

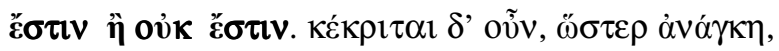

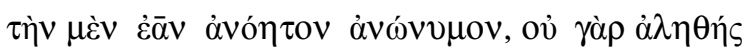

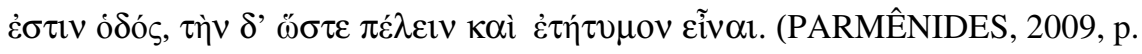
68-69, grifos do tradutor)

O ser, aquilo que a própria justiça - expressamente citada no fragmento 8 , acima - sempre decidiria em favor dada sua autenticidade inata, passa a ser identificado com a própria figura da necessidade ${ }^{61}$.

Neste passo, o ser (o único, o indestrutível, o necessário, o imóvel) com Parmênides é identificado com o próprio (e perfeito) caminho pelo qual o homem, como parte não

\footnotetext{
${ }^{61}$ Nesta mesma linha: “[...] Parménides atribui [ao objeto do pensamento] os mesmos caracteres que Xenófanes reconhecera no deus-tudo. Mas estes caracteres são por ele reconduzidos à única modalidade fundamental, que é a da necessidade. 'O ser é e não pode não ser' (fr. 4, Diels) é a tese principal de Parménides: [...]." (ABBAGNANO, 2006, p. 46-47). Sendo importante complementar que, para Parmênides, a necessidade "[...] a respeito do tempo é eternidade, isto é, contemporaneidade, totum simul; a respeito do múltiplo é unidade, a respeito do devir (ou seja, do nascer e perecer) é imutabilidade." (ABBAGNANO, 2006, p. 47).
} 
destacável da natureza ( $\phi v ́ \sigma ı \varsigma$ ), desde sempre esteve fadado (lançado, diria Heidegger milênios depois) a percorrer, sofrer, atravessar ( $\pi \rho \alpha ́ \sigma \sigma \varepsilon ı v)$.

Temos a forte impressão que tal narrativa está deveras imbuída de uma tonalidade ético-comportamental e pragmática, e este ponto é muito importante para nossas (des)construções.

Nesta recontadíssima história, parece-nos que os riscos e perigos inerentes ao mundo, os quais circundam e afrontam a todos reiteradamente em sua quotidianidade individualmente considerada, na realidade deixariam de representar qualquer perigo efetivo se ouvíssemos nossa razão e buscássemos o caminho correto em nossas decisões (sejam elas de caráter meramente contemplativo ou não).

De alguma forma, seja ela revelada ou não, intuída ou matematicamente pensada, quista ou tiranicamente imposta, teríamos como encontrar o ser, aquilo que necessariamente é, inclusive aquilo que necessariamente seria bom, justo e, quiçá, jurídico. Não só teríamos como encontrar como, para sermos virtuosos, deveríamos fazê-lo.

Para Parmênides muito provavelmente um debate acerca da Guilhotina de Hume sequer faria muito sentido. Para ele, ser e dever-ser são unos, pois imutavelmente necessários e para sempre enredados um ao outro, impelindo, forçando, obrigando, coagindo (seja o pensamento, sejam as ações).

Em Parmênides, a pujança mítica (necessária e necessitante) do ser, e por consequência do ser-jurídico, parece-nos tão inescapável e presente a ponto de o Eleata excluir até mesmo a possibilidade do não ser, que é visto como uma aberração

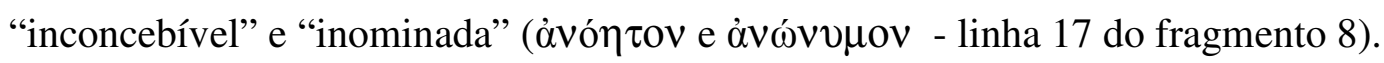

Entre o ser (absoluto) e o não ser (inominável), o Eleata não titubeia um segundo, e decide-se pelo ser que, em nossa interpretação, acaba por não ter vida separada do dever-

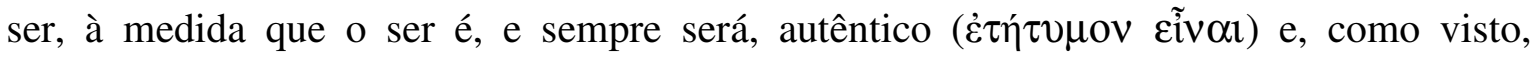
necessário. 
Contudo, em vista dos parcos fragmentos que sobreviveram, não é possível encontrar em Parmênides um detalhamento do que seria a necessidade ou mesmo o sernecessário.

Para tanto, temos que avançar no tempo para consultarmos como Aristóteles, quase dois séculos após a morte de Parmênides, concebia a necessidade e o ser, em função mesmo de sua intensa vinculação com a escola fenomenológico-existencial.

Em outras palavras: seria o ser, para Aristóteles, realmente imperecível, completo, único, imóvel e perfeito, como gostaria Parmênides? Ao interpretar o ser, teríamos então um único ser, um único caminho, e ponto final? Há mesmo apenas um modo de ser?

\subsection{3. $\quad$ O ser-necessário em Aristóteles}

Com relação à unidade interpretativa do ser proposta pelos eleatas, Aristóteles não deixa dúvida acerca de sua posição contrária: embora fosse possível dizer que o ser é com referência a uma unidade e realidade determinada (para ele metamorfoseada no conceito de

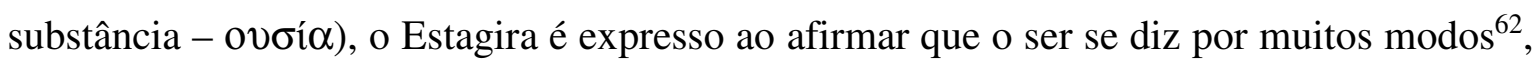
e não por um só, como gostaria Parmênides.

Muito embora Aristóteles não tenha tratado o ser-necessário como um dos quatro modos fundamentais aos quais se reduziria o ser em sua radicalidade-fundativa mais própria, entendemos que será importante ressaltarmos o tratamento dado à matéria, pelos fins mesmos a que esta Dissertação se propõe a tentar alcançar.

Aristóteles tratou explicitamente acerca do conceito de necessidade nos fragmentos 1015a, linhas 20-36 e 1015b, linhas 1-15, do Livro $\Delta$ de sua Metafísica, o qual muitos estudiosos consideram ser um livro pelo qual se tentou fazer um léxico filosófico aplicável aos demais livros da obra (tentativa essa levada a efeito pelo próprio Aristóteles, ou posteriormente por quem a tenha compilado, não se sabe ao certo).

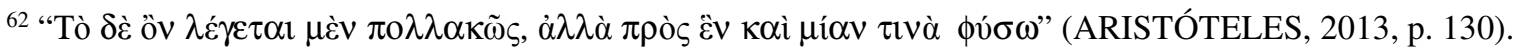


Seja como for, para o Estagira existiriam quatro significados fundamentais para o termo "necessário" (åv $\alpha \gamma \chi \alpha i ̃ o v)$, quais sejam:

\section{Primeiro significado}

Inicialmente, necessário significaria "aquilo sem cujo concurso não é possível viver", sendo que neste caso Aristóteles elenca a respiração e o alimento como exemplos de elementos que são "necessários ao animal porque este não pode existir sem eles"63.

Ainda dentro desta acepção, necessário também significaria "aquilo sem o que o bem não pode existir nem se produzir, ou aquilo sem o que o mal não pode ser eliminado ou evitado", como tomar um remédio para não se ficar doente (ARISTÓTELES, 2013, p. 200201).

Neste sentido, nos parece que Aristóteles tencionava tratar o necessário como algo que condicional e funcionalmente seria mister ocorrer, cuja inexistência de alguma forma impediria inclusive que o próprio bem possa existir ou ser gerado

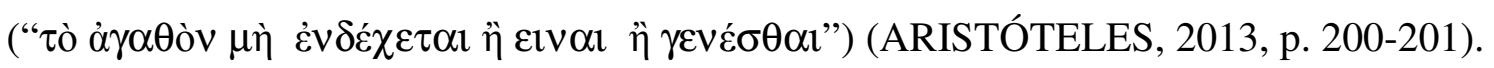

\section{Segundo significado}

O termo necessário significaria também "aquilo que obriga e a obrigação"

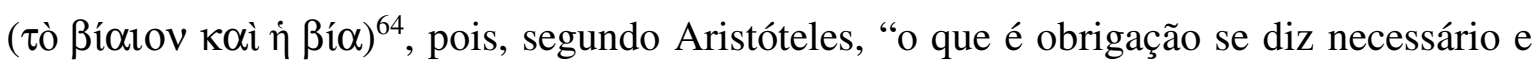

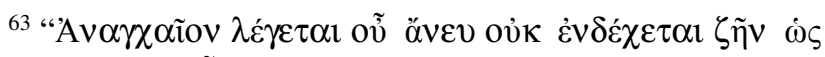

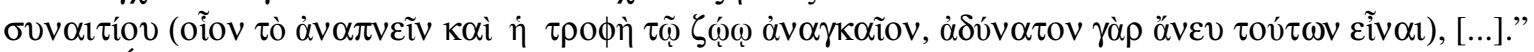
(ARISTÓTELES, 2013, p. 200-201).

${ }^{64}$ É bastante factível ampliar a interpretação para que o texto seja analisado de forma a se propor que Aristóteles não teria apenas sugerido que o que obriga é necessário, mas sim que é necessário aquilo que causa/tem violência, força, aquilo que se impõe e constrange ( $($ íoılov) bem como a própria violência, força, imposição e o poder de constranger e obrigar ( $\beta i ́ \alpha)$. De fato, já em Hesíodo podemos encontrar menção à personificação da

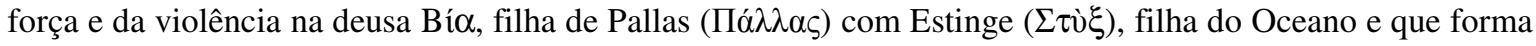
o rio que separa a Terra do mundo de Hades, o submundo dos mortos dos gregos antigos. Bía, e seus irmãos

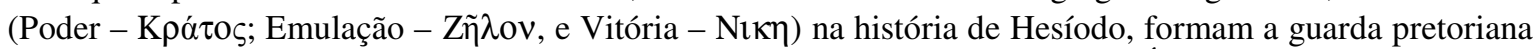
de Zeus, ao lado dele inclusive sentando-se em seu trono no Olimpo (HESÍODO, op. cit., p. 58-59). Modernamente, podemos apresentar os seguintes exemplos nos quais tal interpretação encontra ampla guarida:

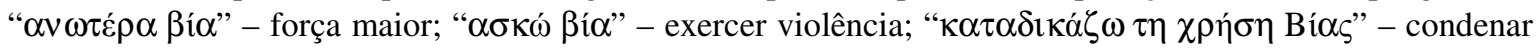

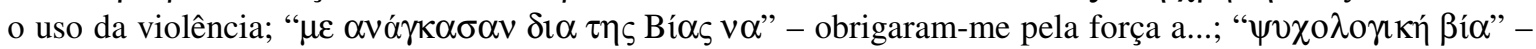

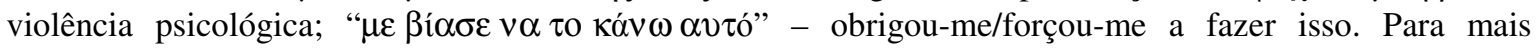


por isso também doloroso, como diz Eveno: 'Tudo o que é necessário é [de] natureza obrigatória”". (ARISTÓTELES, 2013, p. 202-203).

Nesta linha, o Estagira arremata, de maneira que nos parece ser muito importante para os fins desta Dissertação, afirmando textualmente que:

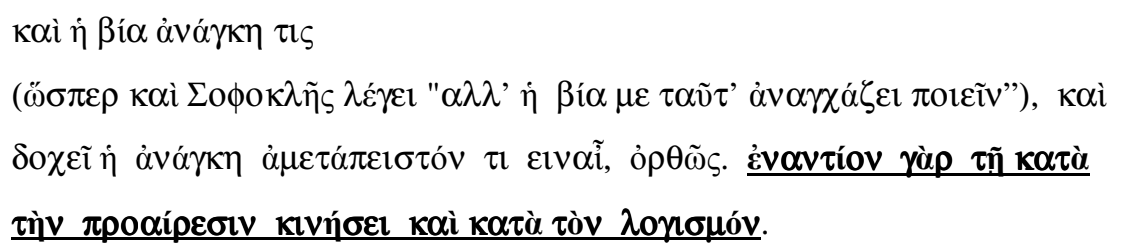

Por esta acepção, em resumo, onde há necessidade, não há deliberação, ou melhor, não há o movimento dela resultante ( espaço-movimento deliberativo, impõe-se interpretar que Aristóteles pressupunha ser inadequado falar de necessidade.

\section{Terceiro significado}

Quanto a este sentido, que em conjunto com o segundo quiçá seja o mais relevante para os fins desta Dissertação, Aristóteles afirma que:

\footnotetext{
Ademais, dizemos que é necessário que seja assim o que não pode ser diferente do que é. E desse significado de necessário derivam, de certo modo, todos os outros significados. De fato, dizemos que o que é obrigado é constrangido a fazer ou a sofrer quando, por força da obrigação, não pode seguir sua tendência, o que significa que a necessidade é aquilo por força do qual uma coisa não pode ser diferente do que é. ${ }^{65}$
}

\footnotetext{
exemplos, cf. MANIATOGLOU, Maria da Piedade Faria. Dicionário Grego-Português. - Porto: Porto Editora, 2010, p. 293.

${ }^{65}$ No original, fragmento 1015a, linhas 33 a 35 e fragmento 1015b, linhas 1 a 4 :

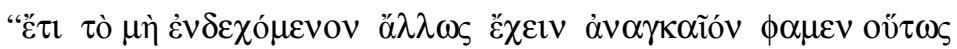

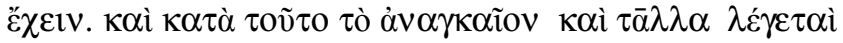

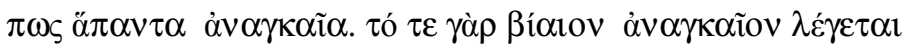


Este posicionamento resumiria assim a perspectiva aristotélica do ser-necessário:

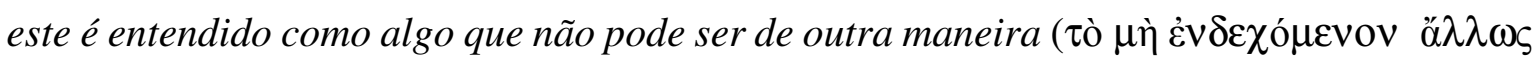

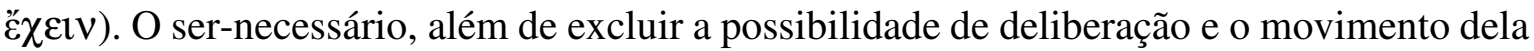
resultante, como visto no segundo significado acima, acaba por excluir também a própria possibilidade de ser de outra forma.

O ser-necessário, em outras palavras, não faz parte daqueles seres que podem ser

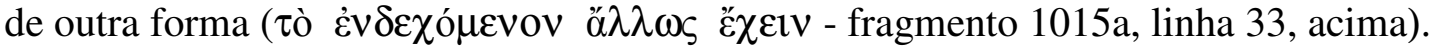

Nesta mesma toada, um pouco mais à frente no texto Aristóteles conclui que:

Portanto o sentido primário e fundamental de necessário é o simples, pois este não pode ser de muitos modos e, consequentemente, não pode ser ora de um modo, ora de outro, pois nesse caso seria de muitos modos ${ }^{66}$.

\section{Quarto significado}

Concluindo seu raciocínio, Aristóteles afirma que dentre as coisas necessárias:

[...] entra também a demonstração, porque [...] não é possível que as conclusões sejam diferentes do que são. E a causa dessa necessidade são as premissas, se é verdade que as proposições das quais o silogismo deriva não podem ser diferentes do que são. (ARISTÓTELES, 2013, p. 202-203)

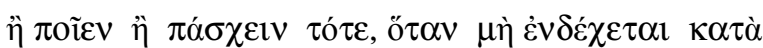

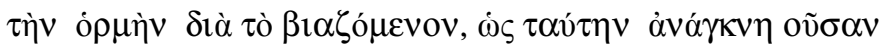

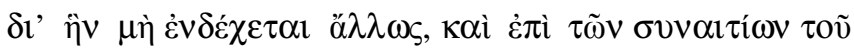

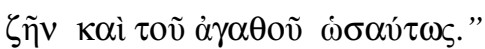
(ARISTÓTELES, 2013, p. 202-203)

Nicola Abbagnano, por seu turno, propõe outra tradução para a parte final do excerto: "Diz-se que é N.[ecessário] aquilo a que somos coagidos quando uma força qualquer nos obriga a fazer ou a sofrer alguma coisa que é contra o instinto, de tal modo que a necessidade consiste, neste caso, em não poder fazer ou sofrer de outra forma." (ABBAGNANO, 2007, p. 818-819).

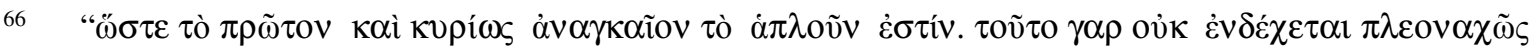

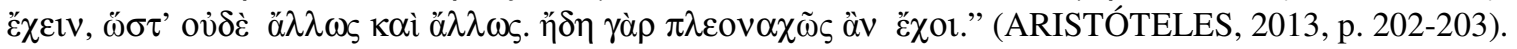


Tendo em vista a coerção $(B 1 \alpha)$ lógica inerente à matemática, que certamente não pode ser de outra maneira do que é (em que pese a excentricidade e os resultados não-triviais a que a moderna física e a geometria não euclidiana por diversas vezes desembocam ${ }^{67}$ ), impõe-se tratá-la, metodológica e ontologicamente, sempre como um ser-necessário.

Dada a clara correlação entre este, o segundo e o terceiro sentidos, há autores, como Abbagnano, que entendem que Aristóteles de fato reduz o conceito de necessário a três que, apenas para reforçar, seriam:

(...) a) o N.[ecessário] como condição ou concausa, em virtude do que se diz, por exemplo, que o alimento é N.[ecessário] à vida (...); b) o N.[ecessário] como força ou coação, em virtude do que se diz que é N.[ecessário] o que impede ou obsta à ação de um instinto ou uma escolha; $c$ ) o N.[ecessário] como o que não pode ser de outra forma, que é o sentido fundamental do conceito. De fato, segundo Aristóteles, os outros sentidos podem ser reduzidos a esse: (...). (ABBAGNANO, 2007, p. 818, grifos nossos)

\subsubsection{O ser-necessário no âmbito do ser-jurídico}

Não foi por mero diletantismo que fizemos uma regressão histórica sobre os primeiros debates filosóficos acerca do ser e da necessidade no mundo ocidental, para culminar em um detalhamento como Aristóteles definiu o ser- necessário.

Tal regressão, antes de ser mero recuo histórico, foi uma tentativa de nos apropriarmos de elementos que a tradição se nos apresenta relativamente ao ser-necessário, em uma narrativa que há muito é recontada, apropriada, repetida e projetada ao longo da história ocidental.

Ao voltarmos para o mundo helênico, podemos trazer conosco elementos que são, sob nosso ponto de vista, muito importantes para que possamos, nos Capítulos seguintes, melhor debater acerca do fenômeno jurídico como um verdadeiro poder-ser, em que a

\footnotetext{
${ }^{67}$ Em um exemplo simplório, ninguém imagina que exista um único triângulo que seja, em uma matemática euclidiana, que possa ter ângulos internos cuja soma seja maior ou menor do que $180^{\circ}$. Neste caso, sempre e necessariamente, o triângulo terá ângulos internos cuja somente é exatamente igual a $180^{\circ}$.
} 
discussão sobre a Guilhotina de Hume vai para além da mera dicotomia entre o dever-ser e o ser.

Ademais, o agarrar-se à tradição, sem a ela permanecer agrilhoado, se fez importante, e talvez com maior propriedade, pois nossa ideia também é aqui apresentar um quadro em que as discussões envolvendo não apenas o fenômeno jurídico, mas sobretudo o fenômeno ético-decisional, o agir humano, o eterno atravessar-por ${ }^{68}$, encontram-se sempre imbuídas de um peso narrativo pré-comprensional e de projeção, em que a miticidade, a cultura e a imitação têm papel crucial, inclusive muito maior do que o papel dado pelo juspositivismo à lei e à "interpretação autêntica".

Entendemos que não é adequado encaminhar a discussão sobre a conduta humana como se absolutizantes eleatas fôssemos, no sentido de que ou nossas decisões são verdadeiras (segundo a razão) ou são falsas (segundo as aparências), ou juridicamente falando, são jurídicas e segundo o dever-ser, ou injurídicas e contra o dever-ser.

Usando o mesmo diapasão, temos que pouco se acrescenta à discussão ao se tratar as decisões humanas como se totalmente irracionais fossem, incapazes de apreensão pela consciência humana.

Novamente como ressaltado por António de Castro Caeiro, ao se recuperar Aristóteles e, sob nosso ponto de vista, a tradição helênica como um todo:

[...] permite uma nova saída para o falso, mas angustiante, dilema em que se enreda a filosofia moral e jurídica contemporânea, em aporia entre cognitivismo e irracionalismo, sugerindo que estas não são as únicas saídas para a filosofia do agir. Antes, desoculta-se a via própria e adequada da racionalidade prática, em cujo horizonte específico redescobre-se o homem como autor do mundo, como criador da ordem e de si mesmo, no exercício da razão prática.

Mas tampouco a ordem figura como fruto da vontade como mero capricho, mas da escolha racionalmente refletida e balizada pelos elementos da situação e

${ }^{68}$ Como bem salientado por António de Castro Caeiro em uma nota de sua tradução para língua portuguesa da Ética a Nicômaco: "O sentido de $\pi \rho \alpha ́ \sigma \sigma \varepsilon ı v$ é atravessar. П $\rho \bar{\alpha} \xi_{\imath} \varsigma$ é a ação de atravessar, enquanto nomen actionis, isto é, aquilo por que passou, os momentos bons e maus que se atravessaram, as circunstâncias concretas que de cada vez se constituem. As situações em que se cai ou que se criam." (Cf. ARISTÓTELES. Ética a Nicômaco. Tradução do grego por António de Castro Caeiro. - São Paulo: Atlas, 2009, p. 250) 
condicionada (possibilitada) pela tradição em que o próprio ser do humano se põe também em jogo e se decide. (ARISTÓTELES, 2009, p. 5).

E mais: a narrativa do ser-necessário não permeia apenas os fundamentos e as discussões das ciências lógico-matemáticas (quarto sentido aristotélico do ser-necessário), as quais, do nosso ponto de vista, diferem metodologicamente das ciências ditas humanas.

Com efeito, entendemos que na história da ética e das discussões acerca do serjurídico, muitas vezes é possível encontrarmos considerações que, no fundo, estão ainda carregadas do estilo apodítico (e quase apoteótico) do ser-necessário. A narrativa do sernecessário, desta forma, acaba transparecendo nos próprios momentos-movimentos do Dasein, sob o viés comportamental - que lhe é o mais próprio de fato).

O ser-necessário acaba por se configurar, em sua análise extrema e sob uma perspectiva jurídico-comportamental, como o único e universal caminho a se seguir, não importando se se trata de um peripato dado pela razão (seja ela prática, ou puramente especulativa), concedido por Deus, forjado pela norma fundamental, construído pela "História" e pelo "Absoluto", ou mesmo se apenas meramente quisto pelo soberano (ou pelo destino), ainda que este existencial lançar-se ao inescapavelmente necessário não iniba seus comentadores, os quais tendem a sustentar, frequentemente com grande eloquência e persuasão, a existência de liberdade e livre-arbítrio em um mundo dominado pela imperiosa necessidade.

Apenas para ilustrarmos o nosso argumento, gostaríamos de mencionar, en passant, dois autores que entendemos deveras originários e especiais para a formação da teoria geral do direito e sua filosofia na atualidade, carregadas que se encontram do viés juspositivista/normativista: Immanuel Kant e Hans Kelsen.

Em que pese o fato de que Kant, em sua teoria do conhecimento, lastreada no pensamento de Wolff ${ }^{69}$, claramente considerava a possibilidade como fundamentadora do

\footnotetext{
69“(...) o ideal racionalista do Iluminismo se concretiza, na obra de Wolff e dos seus numerosos seguidores alemães, no método da razão fundamentadora, a qual procede mostrando a cada passo o fundamento dos seus conceitos na possibilidade. A coincidência de fundamento e possibilidade é a característica deste método, o qual, portanto, dá como fundado (isto é, justificado) um conceito quando se possa demonstrar a possibilidade desse conceito, isto é, a falta de contradições internas.” (ABBAGNANO, 2000b, p. 105).
} 
conhecimento $^{70}$, e não meramente no sentido lógico-proposicional como Kant aparenta afirmar em uma nota feita à sua Crítica da Razão Pura ${ }^{71}$, sua teoria da ação (isto é, sua análise acerca do direito e moral/ética) encontra respaldo em outro baluarte: o da universalidade necessária dos preceitos morais e da correlata universalidade do direito (chamado por ele de "estrito" ou "puro", por ausentes considerações imediatas acerca da ética, moralidade ou religiosidade).

Sem querer aqui adentrar em sua perspectiva a fundo, no que toca à moral e ao direito Kant delineia seu posicionamento acerca do seu caráter universal e universalizante (que nada mais é do que o ser-necessário com notas reforçadoras da sua necessidade temporal - em qualquer tempo - e espacial - em qualquer lugar) em dois livros: na sua Crítica da Razão Prática ${ }^{72}$ e na Metafísica dos Costumes $^{73}$.

Já no começo do primeiro capítulo da sua Crítica da Razão Prática, Kant apresenta sua clássica diferenciação entre imperativos hipotéticos e imperativos categóricos. Embora um tanto longa, entendemos justificável a transcrição de parte considerável do escólio por ele usado para justificar a diferenciação:

A regra prática é sempre um produto da razão, porque prescreve a ação como meio para o efeito, considerado como intenção [Absicht]. Entretanto, para um ser no

\footnotetext{
${ }^{70}$ A força da possibilidade pode ser verificada já no início da sua Crítica da Razão Pura, ao colocar como o verdadeiro problema da razão pura (especulativa) na questão: "como são possíveis juízos sintéticos a priori?" (item VI da Introdução). E alguns parágrafos à frente Kant arremata: "Na solução do problema acima está compreendida ao mesmo tempo a possibilidade do uso puro da razão na fundamentação e no desenvolvimento de todas as ciências que contêm um conhecimento teórico a priori de objetos, i.e., a resposta às seguintes questões: Como é possível a matemática pura? Como é possível a ciência pura da natureza?" (KANT, Immanuel. Crítica da razão pura. Tradução e notas de Fernando Costa Mattos. - $3^{\text {a }}$ ed. Petrópolis/RJ: Vozes; Bragança Paulista/SP: Editora Universitária São Francisco, 2013, p. 56-57) E, torna-se indiscutível o caráter fundante da possibilidade quando afirma que "é a possibilidade da experiência, portanto, que fornece realidade objetiva a todos os nossos conhecimentos a priori." (KANT, 2013, p. 185).

${ }^{71}$ De fato, em uma nota elaborada pelo próprio Kant, constante da quarta seção do terceiro capítulo do segundo livro da dialética transcendental, que trata da impossibilidade de uma prova ontológica a existência de Deus, o mestre de Königsberg afirma textualmente que o "conceito é sempre possível caso não se contradiga. Esta é a característica lógica da possibilidade, e seu objeto é assim distinguido do nihil negativum." Mas ele admoesta claramente contra a mera possibilidade lógico-proposicional, ao afirmar que o conceito, seja lá qual for, pode vir a se demonstrar vazio caso "a realidade objetiva da síntese, pela qual o conceito é engendrado, não seja particularmente demonstrada; o que, no entanto, baseia-se sempre, tal como acima mostrado, em princípios da experiência possível, e não no princípio da análise (o princípio de contradição). Esta é uma advertência para que da possibilidade (lógica) do conceito não se infira de pronto a possibilidade (real) das coisas." (KANT, 2013, p. 465).

${ }^{72}$ KANT, Immanuel. Crítica da razão prática. Tradução de Rodolfo Schaefer. - $3^{\text {a }}$ ed. São Paulo: Martin Claret, 2011.

${ }^{73}$ KANT, Immanuel. A metafísica dos costumes. Tradução de Edson Bini. - 2a ed. Bauru/SP: EDIPRO, 2008.
} 
qual a razão não é o único princípio da determinação da vontade, essa regra é um imperativo, ou seja, é uma regra designada por um dever [Sollen], que determina a obrigação [Nöttigung] objetiva da ação, e significa que, se a razão determinasse completamente a vontade, a ação ocorreria inevitavelmente conforme tal regra. Assim, os imperativos têm um valor objetivo e são inteiramente distintos das máximas, enquanto estas são princípios subjetivos. Os imperativos determinam ou as condições da causalidade do ser racional como causa eficiente, unicamente em consideração do efeito e capacidade para produzi-lo, ou então determinam apenas a vontade, seja ou não ela suficiente para o efeito. Os primeiros seriam imperativos hipotéticos e conteriam simples preceitos de habilidade [Geschcklichkeit]; os segundos, ao contrário, seriam categóricos e unicamente leis práticas. Assim, as máximas certamente são princípios [Grundsätze], mas não são imperativos. Porém, os próprios imperativos, quando condicionados, isto é, quando não determinam a vontade apenas como vontade, mas somente em vista de um efeito desejado, ou seja, quando são imperativos hipotéticos, constituem sem dúvida preceitos práticos, mas não leis. Estas últimas devem determinar suficientemente a vontade, antes ainda que eu indague se tenha a faculdade necessária para um efeito desejado, ou o que devo fazer para produzir esse efeito; devem, consequentemente, ser categóricas, pois, caso contrário, não seriam leis, faltandolhes a necessidade, a qual, se tem de ser prática, tem de ser independente de condições patológicas e, por isso mesmo, ligadas de modo contingente à vontade. $[\ldots]$

A razão, da qual unicamente pode sair toda regra que deve conter NECESSIDADE, inclui também nesse seu preceito a NECESSIDADE (pois sem esta não seria nenhum imperativo); [...]. (KANT, 2011, p. 32-33, grifos nossos)

Do excerto acima notamos que na primeira menção ao conceito de necessidade, pela qual Kant admite a perquirição acerca de uma "faculdade necessária", claramente estáse a tratá-la na primeira acepção aristotélica: necessidade enquanto condicionante ou mecanismo funcional para alcançar-se algo. A necessidade, enfim, quando considerada como concausa (funcional).

Nas três menções subsequentes, entretanto, Kant trata a necessidade modalmente, isto é, como uma das formas pelas quais o conteúdo de um conceito relacionar-se-ia com o sujeito do conhecimento (ou, em outras palavras, como ocorreria a sua predicação) ${ }^{74}$. A

74 A modalidade, como será melhor abordado no próximo Capítulo, segundo a tradição ligada à lógica aristotélico-escolástica, seria caracterizada como as "diferenças da predicação, ou seja, os diferentes modos como um predicado se refere a um sujeito num enunciado." (ABBAGNANO, 2007, p. 788). Muito embora a necessidade como concausa (primeiro significado fornecido por Aristóteles) possa ser analisada, 
necessidade não é mera concausa: em sua relação com o ser-humano, ela acaba sendo percebida como ínsita não apenas à lei, à regra (sem a qual "não seria nenhum imperativo"); mas, e ainda mais importante, a regra, para ser necessária, tem que necessariamente advir da razão e viger universalmente.

Tanto a norma como sua causa eficiente (a razão) mover-se-iam no campo da necessidade, sempre constante, sempre atuante, sempre presentemente já constituída.

Para Kant, embora a necessidade (o ser-necessário) a princípio não acrescentasse nada ao conceito de norma, enquanto uma das três categorias da modalidade ${ }^{75}$, dela seria parte integrante e inseparável, sendo que a norma dependeria intrinsicamente da necessidade inclusive para ser.

Indo exatamente na mesmíssima direção, logo na introdução à Metafísica dos Costumes Kant deixa escancarada sua posição acerca da diferença entre a ética e o direito, sem abandonar a necessidade como baluarte em que ambos apegar-se-iam de maneira inafastável:

Em toda legislação (quer prescreva ações internas ou externas e quer as prescreva a priori pela razão somente ou pela escolha de um outro) há dois elementos: em primeiro lugar, uma lei, que representa uma ação que precisa ser realizada como objetivamente necessária, isto é, que faz da ação um dever; em segundo lugar, um motivo, o qual relaciona um fundamento para determinação da escolha a essa

eventualmente, como uma modalidade da predicação tal como os demais significados aristotélicos afeitos à necessidade, nós entendemos que tal necessidade tem uma acepção muito mais restrita do que os outros significados apresentados por Aristóteles, tendo muito mais a ver com uma condição (que, para Kant, no máximo daria espaço para um imperativo hipotético), como algo necessário para algo ser feito, pensado, quisto ou para meramente permanecer (para viver - o alimento é necessário para a vida -, para comer - a boca é necessária para comer - etc.) do que algo que existencialmente estaria ligado à vida e às decisões cotidianas

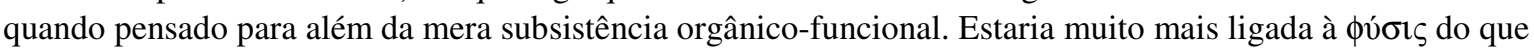
ao $\varepsilon$ éç. Por esta razão, diferenciamos as menções que Kant fez no excerto acima, para destacar a diferença entre a necessidade como concausa (físico funcional) e a necessidade existencial (terceiro significado aristotélico).

$75 \mathrm{Na}$ linha de sua diferenciação entre juízos sintéticos e analíticos (pela qual os primeiros, também denominados de "juízos de ampliação", "acrescentam um predicado ao conceito do sujeito que não era nele pensado", e em que os últimos, também chamados de "juízos de explicação", "não acrescentam nada ao conceito do sujeito por meio do predicado, mas apenas o decompõem nos seus conceitos parciais" (KANT, 2013, p. 51), Kant expressamente afirma que as categorias da modalidade (que para ele, na toada da tradição aristotélico-escolástica, seriam o ser-possível, o ser-real e o ser-necessário) têm "a peculiaridade de não aumentar sequer minimamente, como determinação do objeto, o conceito a que são acrescentadas como predicados; elas apenas exprimem a sua relação às faculdades de conhecimento.” (KANT, 2013, p. 226). 
ação subjetivamente com a representação da lei. Daí o segundo elemento é o seguinte: que a lei torne dever o motivo. [...].

Essa legislação que faz de uma ação um dever, e também faz deste dever o motivo, é ética. Porém, a legislação que não inclui o motivo do dever na lei e, assim, admite um motivo distinto da ideia do próprio dever, é jurídica. (KANT, 2008, p. 71, grifos nossos).

Não é à toa que Kant postulava o direito em bases universais, isto é, os momentosmovimentos do ser-jurídico deveriam ser sempre pensados e concatenados de modo a seguirem o princípio universal do direito, resumida na seguinte máxima: "qualquer ação é justa se for capaz de coexistir com a liberdade de todos de acordo com uma lei universal, ou se na sua máxima a liberdade de escolha de cada um puder coexistir com a liberdade de todos de acordo com uma lei universal.” (KANT, 2008, p. 76-77)

Ora, nada mais necessário do que algo que seja válido universalmente, isto é, que vigore (ou que deveria vigorar, segundo Kant) sempre e em todo lugar. E para a doutrina kantiana, a qual inegavelmente influenciou sobremaneira muitos filósofos e juristas ulteriores, nada mais horrendo e perigoso do que imaginar que a razão, seja ela meramente especulativa ou visando à ação prática, possa não ser universal ${ }^{76}$.

Dado o seu idealismo (transcendental) e seu universalismo humanista (de caráter pacificista), Kant normalmente não é analisado como se integrante do clube dos juspositivistas/normativistas fosse, os quais são às vezes retratados, com frequência injustamente (como ocorre muitas vezes com Kelsen), outras nem tanto, como meros fascínoras (e fascistas) legalistas que se encontram indissoluvelmente aferroados à lei e à sua interpretação autêntica, mantendo-se alheios à realidade (verdade) social.

Contudo, na Metafísica dos Costumes, Kant exalta alguns pontos que, de um jeito ou de outro, voluntariamente ou não, tornaram-se bastiões do juspositivismo legalista ao expressamente igualar o ser-jurídico com a potência ${ }^{77}$ de empregar coerção:

\footnotetext{
76 “A universalidade é a marca dos imperativos categóricos. Isso quer dizer, há uma pressuposição da aplicação universal e de um querer advindo de uma pressuposta universalidade dos agentes. A universalidade é uma medida fundamental do pensamento prático kantiano. Sua flexibilização, abominável à razão.” (MASCARO, 2012, p. 219).

${ }^{77}$ Em que pese o fato de o genial filósofo de Königsberg utilizar os termos "possibilidade" e "competência" ao tratar da coerção ínsita ao ser-jurídico, parece-nos claro neste excerto que tais acepções têm muito mais a ver com o ser- potência aristotélico do que a possibilidade existencial. E essa diferenciação nos é muito
} 
Um direito estrito pode também ser representado como a possibilidade de um uso inteiramente recíproco de coerção que é compatível com a liberdade de todos de acordo com leis universais.

Esta proposição exprime, efetivamente, que o direito não deveria ser concebido como constituído por dois elementos, a saber, uma obrigação de acordo com uma lei e uma competência de quem, por meio de sua escolha, submete outrem à obrigação para coagi-lo a cumpri-la. Ao contrário, pode-se localizar o conceito do direito diretamente na possibilidade de vincular coerção recíproca universal com a liberdade de todos, isto é, tal como o direito geralmente tem como seu objeto somente o que é externo nas ações, o direito estrito - a saber, aquele que não está combinado com nada ético - requer apenas fundamentos externos para determinar a escolha, pois somente então é ele puro e não mesclado a quaisquer preceitos da virtude. um direito completamente externo pode, assim, ser chamado de estrito (direito em sentido estrito). Este realmente se baseia na consciência de obrigação de todos de acordo com uma lei; mas, se for para permanecer puro, não é permissível e nem se pode recorrer a essa consciência como um motivo para determinar a própria escolha de acordo com essa lei. Ao contrário, o direito estrito se apoia no princípio de lhe ser possível usar constrangimento externo capaz de coexistir com a liberdade de todos de acordo com leis universais. [...] Direito e competência de empregar coerção, portanto, significam uma e única coisa. (KANT, 2008, p. 78, grifos no original).

Parece-nos que se torna mais clara agora a vinculação de Kant com os juspositivistas e normativistas em geral. Estes, como Hans Kelsen, defendem a separação entre o mundo do ser e o do dever-ser (além da separação mesma do direito dos demais fenômenos de caráter normativista-regulatório).

Nesta percepção, o conceito de "direito estrito" que Kant apresenta no excerto acima é substancialmente correlato $^{78}$ à teoria de Hans Kelsen acerca da pureza que deveria

importante pois, para os fins desta Dissertação, ao usar a competência/potência de empregar coerção como lastro para a explicação do que seria o direito, temos como reforçada nossa percepção de que Kant move-se dentro do âmbito da necessidade como modalidade primordial do ser-jurídico, visto que a potência aristotélica ( $\delta v v \alpha \mu \mathrm{i} \varsigma$ ) nada mais é do que um simples momento-movimento pelo qual o ser passa para alcançar sua

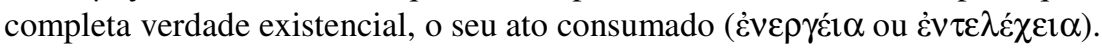

78 Especialmente no que diz respeito à Guilhotina de Hume, o débito de Kelsen para com Kant já foi mencionado por diversas vezes, mas gostaríamos de aqui reproduzir os sempre pertinentes comentários do Professor Comparato sobre o assunto, para que não haja dúvida subjacente ao tema: "A 'teoria pura do direito' reafirma, basicamente, as ideias da analytical jurisprudence de John Austin sobre o direito e a moral. Mas entre ambos os autores, há uma diferença intelectual bem marcada. O pensamento de Kelsen tem uma origem kantiana, ao passo que Austin sempre se moveu no quadro do utilitarismo anglo-saxão. Para Kelsen, o direito 
permear toda a ciência do direito (sua conhecida Teoria Pura do Direito - Reine Rechtslehre), embora Kelsen tenha apregoado, diferentemente de Kant, que pura seria a teoria acerca do ser-jurídico, e não o direito em si.

Com efeito, tal como bem admoestado pelo Professor Alysson Mascaro, é muito importante que, ao se ler Kelsen:

[...] se faça a distinção entre direito e ciência do direito para entender que Kelsen não apregoa, como o vulgo imagina, que o direito seja puro, somente normativo. Pelo contrário, o direito é contraditório, haurido imediatamente das contradições sociais e de seus operadores. (MASCARO, 2012, p. 341).

Kelsen, de fato, pugna por algo menor: "a ciência do direito é que deve ser entendida como pura. Claro, menor que a pretensão a um direito puro, mas, ainda assim, vítima de uma pureza teórica que, ao final, torna a ciência do direito aquilo que o direito não é.” (MASCARO, 2012, p. 341).

Feitas essas observações, porém, temos para conosco que, em uma análise superficial, poderia passar despercebida em Kelsen a pujança do ser-necessário (no sentido de que a sua teoria depende sobremaneira do ser-necessário para ter lastro), muito embora ele possa não manifestar sua posição de maneira aberta e inconteste.

Neste sentido, em conhecida passagem da Teoria Pura do Direito, citada algumas vezes para demonstrar a incongruência kelseniana ao sustentar uma completa separação entre o mundo do ser e o do dever-ser (Cf. COMPARATO, 2006, p. 357-359), Kelsen aparenta inclusive negar o ser-necessário no âmbito em que se temporifica e movimenta o ser-jurídico:

Como a vigência da norma pertence à ordem do dever-ser, e não à ordem do ser, deve também distinguir-se a vigência da norma da sua eficácia, isto é, do fato real de ela ser efetivamente aplicada e observada, da circunstância de uma conduta humana conforme à norma se verificar na ordem dos fatos. Dizer que uma norma vale (é vigente) traduz algo diferente do que se diz quando se afirma que ela é

pertence ao mundo do dever-ser; logo, não se há de pensar, juridicamente, com base no que é ou acontece no mundos dos fatos, pois o dever-ser não deriva do ser nem vice-versa.” (COMPARATO, 2006, p. 357). 
efetivamente aplicada e respeitada, se bem que entre vigência e eficácia possa existir uma certa conexão. Uma norma jurídica é considerada como objetivamente válida apenas quando a conduta humana que ela regula lhe corresponde efetivamente, pelo menos numa certa medida. Uma norma que nunca e em parte alguma é aplicada e respeitada, isto é, uma norma que - como costuma dizer-se não é eficaz em uma certa medida, não será considerada como norma válida (vigente). Um mínimo de eficácia (como sói dizer-se) é a condição da sua vigência. No entanto, deve existir a possibilidade de uma conduta em desarmonia com a norma. Uma norma que preceituasse um certo evento de antemão se sabe que necessariamente se tem de verificar, sempre em toda a parte, por força de uma lei natural, seria tão absurda como uma norma que preceituasse um certo fato que de antemão se sabe que de forma alguma se poderá verificar, igualmente por força de uma lei natural. (KELSEN, p. 1112, grifos nossos).

Contudo, entendemos que as referências à possibilidade e à necessidade, feitas pelo autor austríaco no excerto acima, não estão tratando da possibilidade e da necessidade sob uma perspectiva existencial: seu viés, como será melhor detalhado no próximo Capítulo, é meramente lógico-proposicional (modal), o qual propomos superar por empobrecer o debate acerca do ser-jurídico, em especial ao se tratar da Guilhotina de Hume, ao tencionar tratar algo inimaginavelmente complexo e cheio de contradições, que é a existência, como se um mero jogral de proposições capazes de encadeamento lógico-computacional fosse.

A pujança do ser-necessário (existencial) em sua teoria, contudo, pode ser notada quando Kelsen monta sua defesa acerca da exigência de se buscar uma teoria pura do direito, sob a justificativa de se tratar de uma questão metodológica.

Da própria pureza da sua teoria acerca do ser-jurídico (por ele tratado como deverser puro), em que sua pretensa cientificidade e objetividade manifestar-se-iam como estrutural e necessariamente presentes, por óbvio resulta a obrigação de aceitá-la como uma teoria do direito que transcende de fato às próprias fronteiras nacionais, e até mesmo às suas tecnicalidades temporalmente inconstantes que, assim, só podem ser tratadas como se universais fossem (o que, conseguintemente, nos traz de volta ao mundo do ser-necessário).

Neste sentido, entendemos que não é demais transcrever um excerto da abertura de sua obra mais conhecida, para que não haja qualquer dúvida sobre a posição que adotamos: 
A Teoria Pura do Direito é uma teoria do Direito positivo - do Direito positivo em geral, não de uma ordem jurídica especial. É teoria geral do Direito, não interpretação de particulares normas jurídicas, nacionais ou internacionais. [...]

Quando a si própria se designa como "pura" teoria do Direito, isto significa que ela se propõe a garantir um conhecimento apenas dirigido ao Direito e excluir deste conhecimento tudo quanto não pertença ao seu objeto, tudo quanto não se possa, rigorosamente, determinar como Direito. Quer isto dizer que ela pretende libertar a ciência jurídica de todos os elementos que lhe são estranhos. Esse é o seu princípio metodológico fundamental.

[...] Quando a Teoria Pura empreende delimitar o conhecimento do Direito em face destas disciplinas, fá-lo não por ignorar ou, muito menos, por negar essa conexão, mas porque intenta evitar um sincretismo metodológico que obscurece a essência da ciência jurídica e dilui os limites que lhe são impostos pela natureza do seu objeto. (KELSEN, 1998, p. 1-3).

E como se fosse uma continuação quase linear do pensamento kantiano, em sua Teoria Geral do Direito e do Estado ${ }^{79}$, escrita onze anos após a primeira publicação da Teoria Pura do Direito (esta ocorrida em 1934), Kelsen afirma textualmente que:

\section{$[\ldots]$, the law is a coercive order.}

If the social orders, so extraordinarily different in their tenors, which have prevailed at different times and among the most different peoples, are all called legal orders, it might be supposed that one is using na expression almost devoid of meaning. What the so-called law of ancient Babylonians have in common with the law that prevails today in the United States? [...] Yet there is a common element, that fully justifies this terminology, and enables the word "law" to appear as the expression of a concept with a socially highly significant meaning. For the word refers to that specific social technique of a coercive order which, despite the vast differences existing between the law of ancient Babylon and that of the United States of today, the law of the Ashantis in West Africa and that of Swiss in Europe, is yet essentially the same for all these peoples differing so much in time, in place, and in culture: the social technique which consists in bringing about the desired social conduct of men through the threat of a measure of coercion which is to be applied in case of

${ }^{79}$ KELSEN, Hans. General theory of law and state. - Cambridge/Massachusetts: Harvard University Press, 2007. 
contrary conduct. What the social conditions are that necessitate ${ }^{80}$ this technique, is an important sociological question. I do not know whether we can answer it satisfactorily. Neither do I know whether it is possible for mankind to emancipate itself totally from this social technique. But if the social order should in the future no longer have the character of a coercive order, if society should exist without "law", then the difference between this society of the future and that of the present day would be immeasurably greater than the difference between the United States and ancient Babylon, or Switzerland and the Ashanti tribe. (KELSEN, 2007, p. 19-20, grifos nossos)

Kelsen entende que o direito é ínsito às sociedades humanas empiricamente conhecidas (da antiga Babilônia aos Estados Unidos da América), sendo ainda uma "técnica social específica" que visa a impelir determinado comportamento sob pena de coerção, comportamento este que, de alguma maneira, seria "desejado", conforme textualmente observamos no fragmento acima. O direito, assim, seria socialmente necessário; portanto, necessário qua concausa (funcional).

\subsection{5. $\quad$ O fraco necessitante (prático) do ser-necessário}

Em suma, nosso ponto de vista vai na linha de que, de um jeito ou de outro, há uma narrativa mitológica que há muito permeia, justificando e doutrinando, o discurso filosófico (e jusfilosófico), e não apenas em seu viés prático-comportamental. A possibilidade, enquanto contraponto dentro do pensamento modal, é basicamente deixada de lado neste tipo de narrativa.

Nesta toada, em um ensaio inicialmente publicado em março de 1952, Abbagnano apresenta sua visão acerca dessa narrativa (ao mesmo tempo teorética e éticocomportamental), com foco no discurso científico do século XIX que, não há dúvida, ainda hoje ressoa em diversos pensadores e textos contemporâneos:

\footnotetext{
Questo atteggiamento era strettamente connesso con la situazione della scienza e della filosofia. Scienza e filosofia parlavano, un secolo fa, il linguaggio della necessità. La scienza riteneva che i fatti naturali costituissero una catena ininterrotta di cause e di effetti, catena della quale ogni anello fosse determinato
}

\footnotetext{
${ }^{80}$ Não se trata da necessidade existencial que entendemos relevante para a apreensão do ser-jurídico, mas a mera necessidade enquanto concausa.
} 
dagli anelli precedenti e determinasse necessariamente quelli seguenti, in modo da costituire un sistema unico e rigido, alla cui necessità non sfuggisse parte o nessun elemento della realtà. [...], le due grandi correnti della filosofia, il positivismo e l'idealismo, parlavano un linguaggio analogo, il positivismo estendendo a tutta la realtà il determinismo causale che la scienza riscontrava o credeva di riscontrare, e l'idealismo sostituendo al determinismo causale un determinismo dialleticorazionale altrettanto necessitance dell'altro. [...] nonostante la loro polemica, le loro differenze e i loro contrasti, l'orizzonte nel quale entrambi vivevano e si muovevano era lo stesso. Tale orizzonte era quello della necessità. Tutto ciò che accade, nella natura e nella storia, deve necessariamente accadere. [...] Perciò pure ogni fatto o accadimento rappresenta un miglioramento o un progresso rispetto ai fatti e agli accadimenti precedenti e prepara e anticipa il progresso futuro. (ABBAGNANO, 1956, p. 38 et seq., grifos no original).

Mas, voltando ao nosso tema, será que só poderíamos pensar o ser-jurídico sob o olhar e o cuidado do ser-necessário? Será que somente a completa separação entre direito e moral poderia ser capaz de tornar a análise acerca do ser-jurídico como digna de nota? Sem necessidade não haveria fenômeno jurídico? Se identificarmos o ser-necessário com o deverser, em sua idealidade constitutiva, temos que acatar o dever-ser como o verdadeiro fundamento do direito?

Não nos parece que o ser-necessário seja, com efeito, tão único assim quando estamos tratando do efêmero humano (cf. item 4.1, Capítulo 4, abaixo).

Pelo contrário, embora aceitemos que a modalidade da necessidade encontra-se presente na existência humana (Dasein), seja no campo das ciências estritamente exatas ou até mesmo quando o ser-humano, em suas decisões, acaba sim por usar a necessidade como uma âncora e defesa contra a angústia que o sentimento do possível às vezes traz, criando assim uma pseudonecessidade, entendemos ao invés que o poder-ser tem inclinação para trazer o que há de mais originário, ao menos sob o ponto de vista ontológico, quando estamos tentando apreender o ser próprio dos fenômenos ditos normativos (tais como o direito, a moral e a religião).

Nesta linha, gostaríamos de mencionar o posicionamento do psicólogo e epistemólogo construtivista Jean Piaget acerca do tema. 
O estudioso suíço, com a ajuda de diversos colaboradores e com base em múltiplas experiências feitas com crianças e jovens ${ }^{81}$, desenvolveu sua teoria no sentido de que desde os primeiros anos de nossa existência passamos a considerar e construir nossa realidade não apenas como uma entidade puramente observável, completando-a posteriormente mediante a construção de relações idiossincráticas entre o ser-possível e o ser-necessário.

Ao contrário, sob o ponto de vista ontológico, o estado inicial é aquele de não diferenciação: a realidade é inicialmente entendida (ou manipulada, como queiram) como sendo necessariamente dada, como se fosse a única possibilidade existencial que teríamos à disposição para manusear (Zuhandenheit).

Piaget assim notou em seus experimentos que, em alguns casos, este apego a tais pseudonecessidades (termo por ele utilizado) inclusive trazia bloqueios ao desenvolvimento cognitivo e emocional de certos indivíduos, exatamente por atrapalhar o desenvolvimento da percepção das outras duas modalidades (que, junto com a necessidade, são complementares entre si), quais sejam, a possibilidade e a realidade.

Para que não haja qualquer dúvida sobre estes pontos, seguem abaixo as palavras do próprio Piaget:

[...] the young subject does not begin by considering reality only, constituted by pure observables, and later complete this by constructing possibilities and necessary relations. Rather, the ontological status of the initial state is one of nondifferentiation: reality as perceived and manipulated appears as being necessarily as it is so that it represents the only possibility, except for occasional variations that are accepted as realizable because they have already been observed, and are, therefore, part of a particular sector of the same nondifferentiated reality. [...] First, the formation of possibilities does not proceed by simple free associations but consists rather in real openings requiring a liberation from limitations and obstacles of varying strength. Second, these limitations result from the fact that within this initial nondifferentiation, reality, possibility, and necessity (genuine, not pseudonecessity) block one another's development - that is, each hinders the development of the other two complementary modalities. (PIAGET, 1987, p. 148).

81 PIAGET, Jean et al. Possibility and necessity. Volume 1: The role of possibility in cognitive development. - Tradução de Helga Feider. Minneapolis/Minnesota: University Minnesota Press, 1987. 
E tal se dá pois os bloqueios e distúrbios que o apego desmedido às pseudonecessidades traz dizem respeito a um choque de construções (cognitivas, emocionais, comportamentais e, portanto, ontológicas) de caráter eminentemente modal, isto é, derivadas que são da própria interpretação que o indivíduo confere à realidade que se lhe apresenta, na sua forma mais bruta, para sua análise e condução práticas.

Sendo que tais análises e conduções comportamentais, quando caracterizadas como bloqueios e distúrbios emocionais e cognitivos resultantes do apego desmedido ao sernecessário, ao menos nos primeiros estágios do desenvolvimento humano tendem a estar relacionadas a capacidades lógico-dedutivas incompletas e subdesenvolvidas:

To understand these initial blockings and disturbances we first need to recall that only reality by itself, composed of known or still unknown objects and events, exists independently of the subject, even though it becomes knowable only under the condition that it gets assimilated and interpreted by the subject. In contrast, possibility and necessity are the products of subjects' activities. Where possibility is concerned, this is clearly true for free combinations of actions; [...]. As for necessity, because relationships between 'real' events can only be general to a greater or lesser extent, their necessity remains part of the models that subjects construct deductively, hence subordinated to the necessary laws pertaining to these deductions themselves.

Given these considerations, it is evident that the initial lack of differentiation results essentially from an insufficiency of subjects' activities concerning possibilities and necessities; what they consider as reality, in turn, comprises illegitimate incursions into the domains of the other modalities to compensate for the as yet undeveloped deductive capacities. (PIAGET, 1987, p. 149, grifos nossos).

Se nossa posição nesta Dissertação é no sentido de que é preciso superar a dicotomia dever-ser/ser, pela sua própria insipidez, e se, como imaginamos já ficou patente, nós pretendemos apresentar um quadro em que o ser-jurídico não está adstrito ao discurso, à narrativa e às limitações da "linguagem da necessidade", nos dizeres de Nicola Abbagnano, a qual outra narrativa filosófico-modal-mitológica poderíamos recorrer para ultrapassar tal linguagem? 
Deste modo, concluímos nossa argumentação acerca da pujança do ser-necessário na jusfilosofia, em que pese considerarmos que ele jamais poderia ser utilizado como fundamento abissal para o direito, passando agora a abordar outra narrativa que entendemos

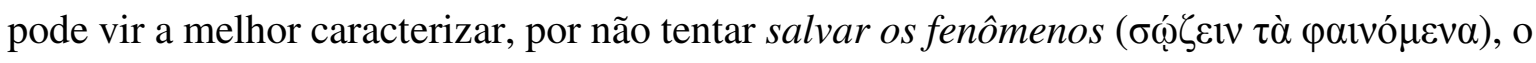
próprio ser-jurídico: a busca pelo ser-possível (ou poder-ser), na medida em que ele passa a agora ser tematizado. 


\section{CAPÍTULO 4. O PODER-SER}

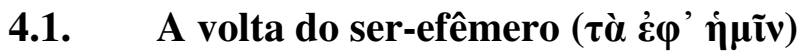

O escritor britânico Neil Gaiman, em que pese sua ampla diversidade de obras (a qual inclui peças teatrais, contos e romances literários, além de roteiros para filmes, HQs e séries de TV), é mundialmente conhecido por ser o autor de umas das graphic novels mais interessantes e premiadas de todos os tempos: Sandman.

Logo no começo da sequência denominada Estação das Brumas ${ }^{82}$, Neil Gaiman apresenta como seria o jardim em que o Destino, o irmão mais velho dos sete Perpétuos (quais sejam: o Destino, a Desencarnação - ou Morte -, o Devaneio - ou Sonho -, a Destruição, a/o Desejo, a Desespero e a Delírio), costuma perambular ao ler o seu livro, no qual todas as decisões/situações tomadas/ocorridas em nosso universo estariam pormenorizadamente narradas:

\footnotetext{
Caminhe por qualquer trilha no jardim de Destino e você será instado a escolher. Não uma, mas muitas vezes. As trilhas se bifurcam e se dividem. A cada passo, você faz uma escolha, e toda escolha resulta em trilhas futuras. No entanto, no fim de uma vida de caminhadas, você pode olhar para trás e ver apenas uma única trilha se estendendo às suas costas; ou olhar para a frente e ver apenas trevas. Às vezes, você sonha com os caminhos de Destino e reflete sem propósito algum. Sonha com as trilhas que seguiu e com as que não seguiu... As trilhas divergemse, ramificam-se e reconectam-se. Dizem que nem mesmo o próprio Destino realmente sabe aonde qualquer caminho há de levá-lo, para onde cada guinada ou mudança direção apontará. Porém, mesmo se Destino pudesse lhe dar a resposta, ele não o faria. Destino guarda bem seus segredos. O jardim de Destino você o reconheceria se pudesse vê-lo. Afinal, há de perambular por ele até morrer. Ou até muito depois. Pois as trilhas são longas e, mesmo na morte, não se encerram.
}

Se compreendermos a modalidade da necessidade (o ser-necessário) como aquela que de fato molda e constitui o nosso mundo ético, entendemos que pouquíssimo espaço

${ }^{82}$ GAIMAN, Neil. Sandman: Edição Definitiva. - Tradução de Jotapê Martins e Fabiano Denardin. $2^{\mathrm{a}}$ ed., vol. II (Estação das Brumas: Um Prólogo). Barueri, SP: Panini Books, 2011, p. 13. 
sobraria para um efetivo momento-movimento livre do ser-humano, tornando o trabalho do perpétuo Destino muito mais fácil (e insípido) do que Gaiman imaginou.

O comportamento humano, constitutivamente amalgamado nas contínuas e dramáticas decisões que as mulheres e os homens veem-se obrigados a tomar, de maneira quotidiana e ininterrupta (apesar de algumas vezes nem ao menos nos darmos conta disso), é muito mais do que um simples basear-se no dever-ser, na necessitante obediência ao direito positivo que, pelo e no juspositivismo, acaba por se tornar o necessário único caminho que nos restaria acompanhar, cega ou criticamente (tanto faz, no final das contas).

Muito pelo contrário: "as trilhas divergem-se, ramificam-se e reconectam-se" pois as "as trilhas são longas e, mesmo na morte, não se encerram", tal como apresentado por Gaiman.

Apesar de nossa singela participação em um cosmos tão maior e existencialmente mais complexo, a própria possibilidade de meramente sermos, de existirmos enquanto tal, e de estarmos aqui para testemunhar e refletir sobre questões dessa estirpe (modo de ser exclusivo do Dasein), demanda que busquemos uma superação de um discurso que nos reduz a simples decifradores e seguidores do direito positivo e de seus corolários.

Afinal, para que o direito positivo pudesse ter efetivamente lugar como verdadeiro fundamento do direito, este, enquanto técnica (e, por consequência, a jusfilosofia como sua base de justificação narrativa e acomodação socialmente enviesada), precisaria estar constitutivamente estruturado como omnipresença inescapável em todos momentos em que decidimos. Para tanto, o direito deveria sempre estar claramente à disposição (à mão) de todos para o fim de permitir sua utilização como ferramenta existencialmente decisória (quotidiana). Coisa que, como vimos, no melhor dos mundos é uma dificuldade, quando não uma mentira deslavada.

Ocorre que uma teoria universalizante e universalizada do fenômeno normativo (como são todas aquelas que de algum modo encontram-se agrilhoadas ao ser-necessário) para vingar dependeria de as decisões dela resultantes, e as responsabilidades que delas decorreriam, estarem calcadas em certos termos e conceitos culturais (e decisionais) que, na realidade, somente alguns poucos iniciados (as tecnossacerdotisas e os tecnossacerdotes) 
têm (muitas vezes de maneira parcial), o que per se torna a possiblidade de uma teoria deste gênero no mínimo claudicante (e, portanto, conflitando com a própria universalização por muitos pretendida).

O juspositivismo recairia, assim, em uma injusta incongruência: sua validade (e, mesmo quando a teoria juspositivista aceita, a busca por justiça) seria devedora direta do ser-necessário, que justifica e impõe obediência ao restringir e pré-determinar os caminhos a serem escolhidos. Por outro lado, sua validade, e os termos pelos quais o fenômeno jurídico poderia ser caracterizado como justo (verdadeiro), somente seriam alcançáveis por aqueles que, de alguma maneira, foram formalmente treinados em nossos templos jurídicos para conduzir os rituais processualizados e os ritos propedêuticos que a tradição lhes concedeu.

O fenômeno jurídico, que era para estar fincado no ser-necessário, e portanto em tese passível de universal compreensão, torna-se na realidade refém de uma massa amorfa de procedimentos e tradições que, muitas vezes, nem mesmo aos olhos e ouvidos das tecnossacerdotisas e dos tecnossacerdotes, têm fundamento (Abgrund) no tecido-abismo social (às vezes, nem ao menos sob o viés técnico e ritualístico, dadas as incongruências estruturais e políticas do fenômeno jurídico, que entendemos não são suplantadas com simples interpretações lógico-proposicionais resultantes da própria ritualização do assim chamado "sistema jurídico").

Enfim, parece-nos que reduzir o debate jusfilosófico a uma tendência narrativa - a da necessidade - que manca por ter um curto apoio prático-existencial, no sentido de aparentar não estar de fato calcada em fenômenos inerentemente gregários (parciais por sua própria natureza) e sim meramente técnico e ritualísticos, peca por, dentre outras razões:

(i) tratar o modo de ser das coisas em geral como equivalente ao modo de ser próprio do ser-humano - o Dasein de Heidegger, aquele ente único que tem consciência (seja a consciência moral ou a intuitiva - Gewissen e Bewusstsein ${ }^{83}$ ) e disposição

\footnotetext{
83 “A palavra alemã [Gewissen] designa, usualmente, a consciência moral dos deveres e obrigações. [...] Uma vez que toda forma de consciência supõe e provém de uma experiência originária de saber (wissen), atingindo a esfera da convivência e copresença em que os homens realizam a sua existência comum e individual, o aprofundamento da consciência se articula com os existenciais. Por isso, em alemão encontra-se além de Gewissen, também o termo Bewusstein, que significa consciência por oposição à inconsciência, igualmente construído a partir do verbo wissen (saber, scientia)." (HEIDEGGER, 2012, p. 577-578, nota 69 da tradutora).
} 
habitual para analisar, sentir, desejar, transpor, pré-ver e interpretar pragmaticamente a sua identidade e as suas diferenças quando em correlação aos outros entes - esquecendo-se de que, como salientado pelo próprio Heidegger, o ser-humano enquanto tal (Dasein) relaciona-se com os demais entes apenas pelo modo de ser próprio da manuseabilidade/manualidade (utilização - ou Zuhandenheit) e da simples aparição (Vorhandenheit), sendo estes, embora correlatos, claramente diferenciáveis do modo de ser próprio do ser-humano;

(ii) pretender conceder ao fenômeno jurídico uma objetividade científica que usa a própria tentativa de igualar os entes em geral com o ser-humano para se autojustificar, sendo que nos parece claro que não há como tratar como científicos uma teoria e um objeto não universal tal qual é o fenômeno jurídico, dadas as suas intrínsecas características em cada território do globo e, o mais importante, como o ser-humano convive diferentemente com tal técnica, a depender do seu horizonte cultural e lógico-tradicionalizante.

Assim, qual seria então o Ur-sprung Ab-grund, o salto originário-originador, a fonte abissal e fundante sempre desde já presente na jusfilosofia, da qual poderíamos haurir um detalhamento acerca do que seria o poder-ser, enquanto alternativa ao ser-necessário?

Para que haja uma melhor apreensão das várias acepções que poderiam ser trabalhadas no que se refere à possibilidade, cuja diferenciação é crucial para os fins desta, consideramos importante mais uma vez usarmos como ponto de partida os ensinamentos de Aristóteles, a quem a fenomenologia e o existencialismo contemporâneos são imensos devedores, auscultando ao que o Estagira lecionava acerca do tema.

Antes de adentrarmos ao Livro $\Delta$ da Metafísica (mais especificamente, ao fragmento 1019a, linhas 15 et seq., em que Aristóteles trata especificamente sobre os significados de potência, impotência, possibilidade e impossibilidade), propositadamente entendemos que faremos melhor em buscar primeiramente no Livro VI da Ética à Nicômaco os excertos que podem nos trazer elementos importantes para nos auxiliar a entender melhor 
a diferença entre uma circunvisão ${ }^{84}$ de mundo calcada na necessidade prática e aquela que se apoia na estrutura ontológico-decisional do poder-ser.

Nesta linha, há uma passagem, logo no início do referido Livro VI da Metafísica, que ilustra muito bem a dicotomia que, em nosso entender, é assaz importante para se entender o debate que subjaz às discussões envolvendo a Guilhotina de Hume (ou melhor, sua superação).

Com efeito, Aristóteles afirma que a alma humana ( $\psi v ́ \chi \eta)$ possuiria duas partes, as quais para ele seriam claramente identificáveis: (i) aquela dotada de racionalidade ( $\tau$ ó $\lambda o ́ \gamma o v$, entendida não no contexto cartesiano/centrossubjetivista de razão fundante, mas sim no sentido que $\lambda$ o $\gamma o \varsigma$ originariamente possuía, em que era ressaltado o seu caráter narrativodiscursivo e, por conseguinte, político ${ }^{85}$ ); e (ii) uma outra parte em que o logos não estaria

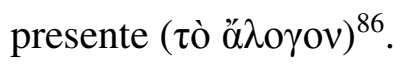

\footnotetext{
${ }^{84}$ Utilizaremos este termo ao longo desta Dissertação tomando-o emprestado da magnum opus de Heidegger (Sein und Zeit), com base na tradução e interpretação feita pela Professora Márcia Sá Cavalcante Schuback. Conforme sua nota de número 18 (que trata exatamente sobre o que ela entende por circunvisão - Umsicht no original): “A construção do mundo cotidiano das ocupações não é cega, mas guiada por uma visão de conjunto, a circunvisão, que abarca o material, o usuário, o uso, a obra, em todas as suas ordens. Esta visão não é uniforme e padronizada nem em seu direcionamento e perspectiva e nem em sua natureza." (HEIDEGGER, 2012, p. 566 , nota 18 da tradutora).

${ }^{85}$ Hanna Arendt é pontual ao afirmar que a definição de ser-humano como ser-político somente poderia ser compreendida em sua integralidade se for a ela acrescentada "a segunda famosa definição aristotélica do homem como zoon logon ekhon ('um ser vivo dotado de fala'). A tradução latina dessa expressão como animal rationale resulta de uma incompreensão não menos fundamental que a da expressão 'animal social'”. De fato, conclui Arendt, ambas as duas definições "Aristóteles apenas formulou a opinião corrente da pólis acerca do homem e do modo de vida político; e, segundo essa opinião, todos os que viviam fora da pólis - escravos e bárbaros - eram aneu logou, destituídos, naturalmente, não da faculdade do discurso, mas de um modo de vida no qual o discurso e somente o discurso tinha sentido e no qual a preocupação central de todos os cidadãos era falar uns com os outros." (ARENDT, Hanna. A condição humana. - Tradução de Roberto Raposo, revisão técnica de Adriano Correia. $11^{a}$ edição. Rio de Janeiro: Forense Universitária, 2010, p. 32, grifos no original). Nesta mesma toada é a interpretação que Barbara Cassin tem do logos originário, ao afirmar que para Aristóteles "a alma é a consistência das reticências entre o fenômeno e lógos, é o lugar entre coisas e palavras - lugar de coincidência, de co-pertinência, de descerramento - [...]. A alternativa objetivo-subjetivo encontrase, dir-se-ia, desde sempre superada." (CASSIN, Barbara. Aristóteles e o lógos: contos da fenomenologia comum. - Tradução de Luiz Paulo Rouanet. São Paulo: Edições Loyola, 1999, p. 16).

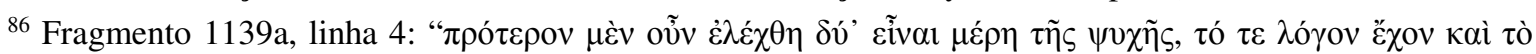

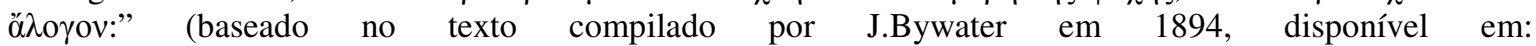
$<$ http://www.perseus.tufts.edu/hopper/text;jsessionid=A015E26CF73BAE15857CDCA0F6AD1BBA?doc=P erseus\%3atext\%3a1999.01.0053 >, página acessada pela última vez em 10/01/2016). António de Castro Caeiro, tradutor do texto da Ética à Nicômaco a que tivemos acesso em nossa pesquisa, assim traduz a referida passagem: "Foi, pois, dito primeiramente que há duas dimensões na alma humana: uma capaz de razão, a outra é incapacitante da razão." (ARISTÓTELES, 2009, p. 129).
} 
Deixando de lado a parte da alma humana que seria não "lógica" (isto é, aquela em que não haveria um com-partilhamento (sic), uma pertinência discursivo-narrativacomportamental com o logos), a outra parte seria subdividida em duas partes: (i) uma em que consideramos "aqueles entes com princípios que não podem ser de outra maneira"

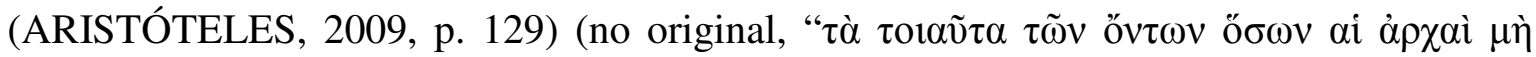

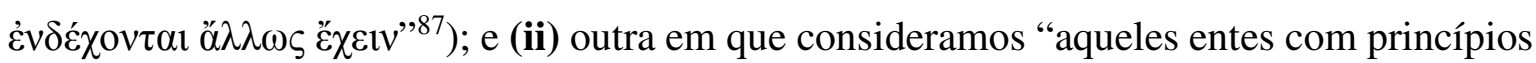
que podem ser de outra maneira" (ARISTÓTELES, 2009, p. 129) (por Aristóteles

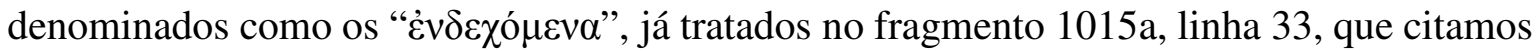
quando da análise do terceiro e principal significado do ser-necessário para Aristóteles).

E mais à frente declara o Estagira que os primeiros (aqueles entes que não podem ser de outra maneira) são tipos de entes que correspondem "à possibilidade de formação de

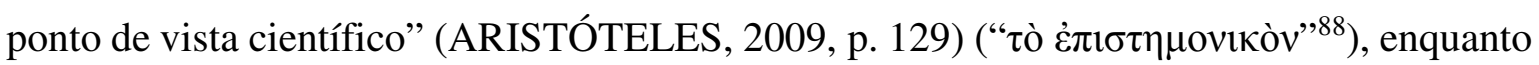

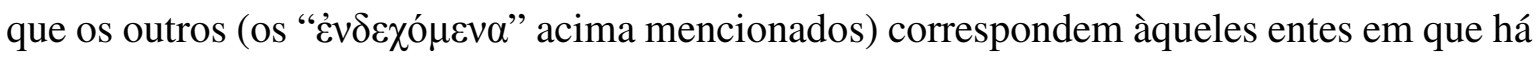
a "possibilidade de cálculo, ou seja, mais propriamente a possibilidade de deliberar e de

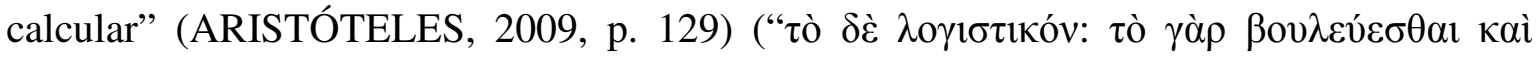

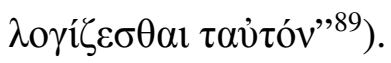

A deliberação, desta forma, passa a adquirir um caráter extremamente importante

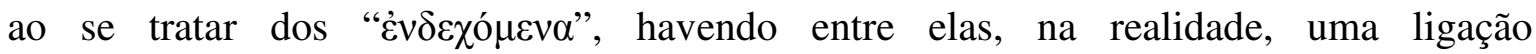
ontologicamente ínsita. Nesta acepção, Aristóteles expressamente declara que:

Na verdade, ninguém delibera acerca daquilo que não pode ser de outra maneira (ARISTÓTELES, 2009, p. 129) ${ }^{90}$.

\footnotetext{
${ }^{87}$ Fragmento 1139a5, linha 6, baseado no texto compilado por J.Bywater em 1894, disponível em: $<$ http://www.perseus.tufts.edu/hopper/text;jsessionid=A015E26CF73BAE15857CDCA0F6AD1BBA?doc=P erseus\%3atext\%3a1999.01.0053 >, página acessada pela última vez em 10/01/2016.

${ }^{88}$ Fragmento 1139a10, linha 12, baseado no texto compilado por J.Bywater em 1894, disponível em: $<$ http://www.perseus.tufts.edu/hopper/text;jsessionid=A015E26CF73BAE15857CDCA0F6AD1BBA?doc=P erseus\%3atext\%3a1999.01.0053>, página acessada pela última vez em 10/01/2016.

${ }^{89}$ Fragmento 1139a, linhas 11-12, baseado no texto compilado por J.Bywater em 1894, disponível em: $<$ http://www.perseus.tufts.edu/hopper/text;jsessionid=A015E26CF73BAE15857CDCA0F6AD1BBA?doc=P erseus\%3atext\%3a1999.01.0053>, página acessada pela última vez em 10/01/2016.

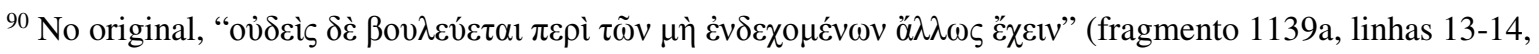
disponível em:

$<$ http://www.perseus.tufts.edu/hopper/text:jsessionid=A015E26CF73BAE15857CDCA0F6AD1BBA?doc=P erseus\%3atext\%3a1999.01.0053>, página acessada pela última vez em 10/01/2016.
} 
Assim, Aristóteles torna manifesta a correlação inerentemente própria entre a

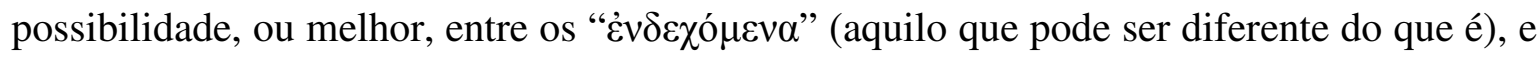
a deliberação humana. Antes mesmo das passagens acima (mais especificamente no Fragmento 1111b), a decisão passa a ser exaltada, ontologicamente falando, ao nível da

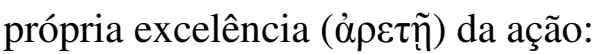

\begin{abstract}
A decisão é, na verdade, o que de mais próprio concerne a excelência e é melhor do que as próprias ações no que respeita à avaliação dos caracteres Humanos.

$[\ldots]$

Em geral, parece que a decisão é acerca das coisas que nos dizem respeito e dependem de nós. (ARISTÓTELES, 2009, p. 60-61) ${ }^{91}$
\end{abstract}

Com relação a tais seres/entes "que nos dizem respeito e dependem de nós" (no

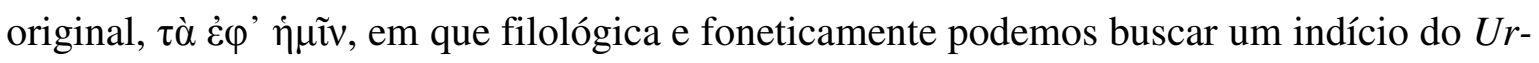

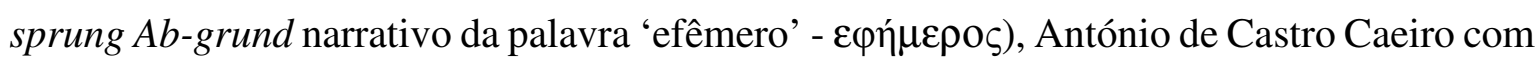
perspicácia observa que:

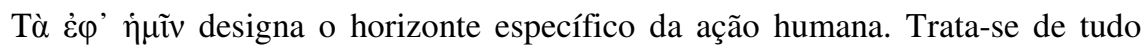
aquilo que é constituído pela ação direta e o que se encontra sob dependência do Humano enquanto tal, ou seja, sem a existência do Humano não haveria nenhum dos objetos, das situações e das circunstâncias que por ele são criadas. (ARISTÓTELES, 2009, p. 256, nota 89 do tradutor).

Inclusive, a aceitação do efêmero como parte importante da existência, ou até mesmo o seu ser-base, torna-se mais aguda ainda um pouco mais à frente na obra, quando Aristóteles usa a correlação intrínseca entre o ser-humano e a decisão (seja na forma de $\pi \rho o \alpha i ́ \rho \varepsilon \sigma l \varsigma^{92}$, seja na forma de $\beta o v ́ \lambda \varepsilon v \sigma l \varsigma^{93}$ ) para formular sua famosa distinção entre ação

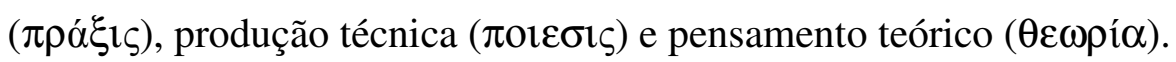

91 Referidas passagens encontram-se no Fragmento 1111b, linhas 6-7 e linha 30, conforme seguem:

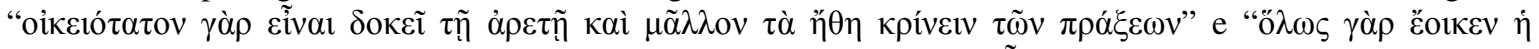

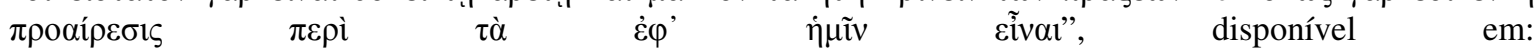
$<$ http://www.perseus.tufts.edu/hopper/text;jsessionid=A015E26CF73BAE15857CDCA0F6AD1BBA?doc=P erseus\%3atext\%3a1999.01.0053>, página acessada pela última vez em 10/01/2016.

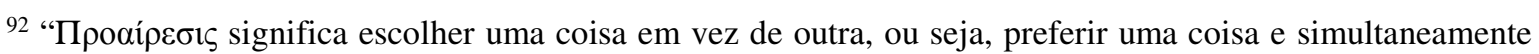
preterir outra. Mas o prefixo designa também uma antecipação que está a constituir um ato de escolha. Tratase, por conseguinte, de uma decisão. Por decisão, define-se determinada situação de natureza indefinida. E doravante as coisas passarão a ser diferentes." (ARISTÓTELES, 2009, p. 250, nota 20 do tradutor).

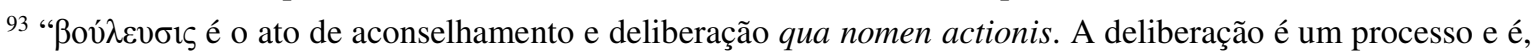
assim, o que serve de base fundamental a toda a decisão. Não há decisão sem deliberação. A decisão é a 
Com efeito, o Estagira afirma peremptoriamente na primeira linha do fragmento

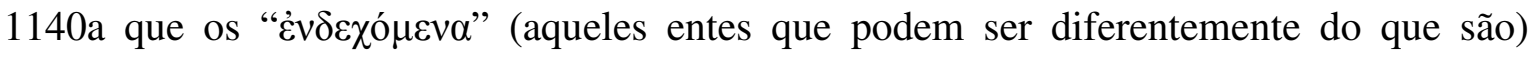
distinguem-se entre aqueles seres/entes voltados à ação $(\pi \rho \alpha ́ \xi \xi \varsigma)$ e aqueles voltados à produção técnica $(\pi 01 \varepsilon \sigma 1 \varsigma)$, sendo que esta não se confunde com a primeira ${ }^{94}$ na medida em que o fim da produção técnica não é encontrável nela mesma, diferentemente da ação, em que o seu fim lhe é interior e próprio.

Estariam assim fora de cogitação (para fins de determinação do que seria um

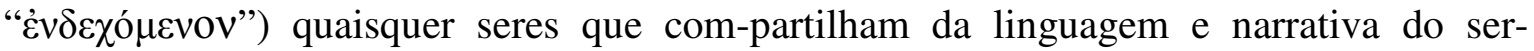
necessário.

Esta conclusão, e a vinculação inerente entre ação prática e deliberação humana, fica patente ao se analisar o fragmento 1139 em conjunto com o fragmento 1140:

O pensamento teórico, que não visa à ação nem à produção, é executado de uma forma correta ou de uma forma incorreta, respectivamente, conforme detecta a verdade ou se envolve em falsidade. Porque esta é, em geral, a função de todo o pensamento. Contudo, a função do pensamento prático é mais propriamente a de obter a verdade que corresponde à intenção correta.

O princípio da ação é a decisão (isto é, enquanto origem da motivação, não enquanto fim em vista); por outro lado, o princípio da decisão é a intenção e um cálculo dirigido para um objetivo final. [...]

O próprio pensamento só por si não põe nada em movimento: apenas quando se dirige para um determinado fim numa determinada ação. É assim também que atua o pensamento produtor, porquanto o produtor de algo tem um determinado fim em vista. É que o produzir como tal não é nenhum fim em si mesmo (mas algo relativo a algo e formador de algo). Por outro lado, já o agir, e, na verdade, o agir bem, é um fim em si mesmo, e a intenção é o princípio da mudança específica que vai na sua direção. Por isso, a decisão é uma compreensão intencional ou uma intenção compreensiva. Neste sentido, o princípio (da ação) é o Humano. Nada do que já

expressão autêntica e o culminar do processo de deliberação." (ARISTÓTELES, 2009, p. 256, nota 91 do tradutor).

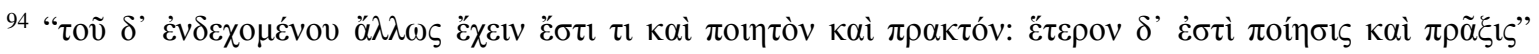
(disponível em:

$<$ http://www.perseus.tufts.edu/hopper/text;jsessionid=A015E26CF73BAE15857CDCA0F6AD1BBA?doc=P erseus\%3atext\%3a1999.01.0053>, página acessada pela última vez em 10/01/2016). 
aconteceu poderá, contudo, ser ainda objeto de decisão. Ninguém pode ainda decidir se Tróia terá sido destruída. (ARISTÓTELES, 2009, p. 130). ${ }^{95}$

Assim, é no efêmero, no ser-passante-já-a-cada-momento-passado-poisdeliberado-ainda-que-projetado-e-pré-compreendido, em toda individual, pequena, porém dramática decisão quotidiana, o local em que o ser-jurídico aparenta ser (e não apenas estar) e a partir do qual se movimenta. É no efêmero, e não no ser-pretensamente-universal do dever-ser, extra-humano por excelência, que há o originário da decisão, à medida que o Sollen é, apenas, idealizado.

É no efêmero, enfim, o lugar no qual se encontra circunscrita a radical possibilidade de transformação e superação a que entendemos estar amarrado o ser-decisão que movimenta o ser-jurídico.

E qual seria o objeto, o âmago do ser-decisão (e não das decisões individualmente consideradas)?

Em um fragmento especial para a jusfilosofia contemporânea, Aristóteles deixa clara a sua posição acerca do tema:

O objeto passível de deliberação e o objeto passível de decisão são o mesmo, com a diferença de que o objeto da decisão está já delimitado de antemão. O que é discernido a partir da deliberação é o que é decidido de antemão. Cada um de nós cessa de procurar o modo como agirá quando reconduz o princípio e origem da ação até si próprio, e por sua vez faz-se reconduzir a si próprio ao princípio condutor: é isto portanto o que é decidido. Isto mesmo é evidente a partir da consideração das formas de constituição antigas que Homero retratou. Os reis só comunicavam ao povo aquelas coisas que previamente já tinham decidido. Sendo o que é decidido antecipadamente deliberado de forma intencional em vista

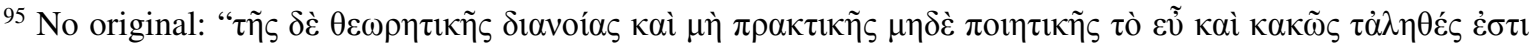

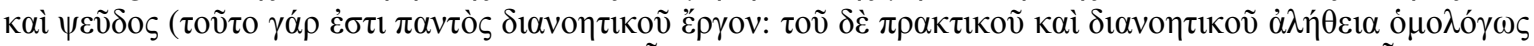

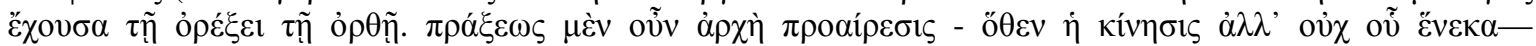

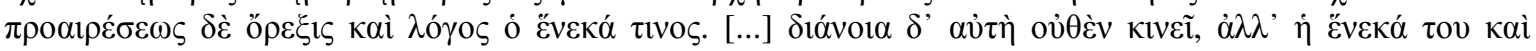

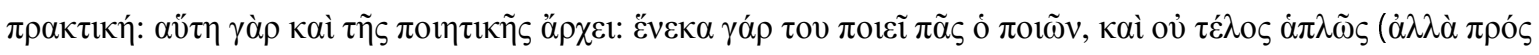

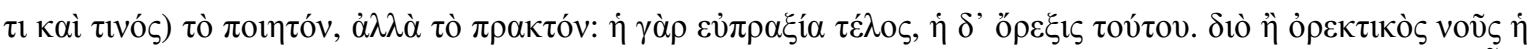

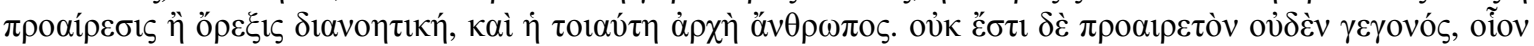

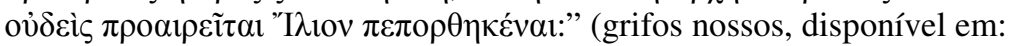

$<$ http://www.perseus.tufts.edu/hopper/text;jsessionid=A015E26CF73BAE15857CDCA0F6AD1BBA?doc=P erseus\%3atext\%3a1999.01.0053>, página acessada pela última vez em 10/01/2016).
} 
daquilo que nos diz respeito e que depende de nós, a decisão será uma intenção deliberante das coisas que nos dizem respeito e que dependem de nós. Discernindo a partir do deliberar, fazemos tenção de acordo com a deliberação. (ARISTÓTELES, 2009, p. 64, grifos nossos) ${ }^{96}$.

Mais à frente nesta Dissertação retornaremos ao debate sobre a centralidade da decisão antecipadamente deliberada (e, em si mesma, efêmera) para o fenômeno normativo (e para o Dasein, entendido como existência/presença analisada sob a ótica da $\pi \rho \alpha ́ \xi_{\imath} \varsigma$, como defendido por Franco Volpi), até mesmo em vista da importância da questão para o pensamento contemporâneo (mormente aquele de viés existencialista e fenomenológico).

Feitas estas considerações acerca do caráter central do efêmero (o intrinsicamente humano) e da decisão, podemos retomar o questionamento envolvendo quais seriam, assim, os diversos tipos de poder-ser e quais seriam suas principais notas definidoras, enquanto contraponto à usual proeminência que o ser-necessário ainda hoje tem quando se trata de explicar o fenômeno normativo.

Sugerimos iniciar a análise considerando o poder-ser enquanto potência/virtualidade, dada sua relevância histórica, embora com efeito seja esta teoria ainda totalmente atrelada ao ser-necessitante daquilo que Abbagnano denominou como a "linguagem da necessidade", e não ao poder-ser em si, como passamos a detalhar.

\subsection{A possibilidade enquanto ser-potência}

No Capítulo 3 julgamos por bem mencionar, ainda que sucintamente, a busca histórica pelo ser (ou pelos sendos/essentes), ressaltando desde o início que nossa pesquisa pretende detalhar melhor o ser sob seu aspecto existencial, e não meramente proposicionalpredicativo.

\footnotetext{
${ }^{96}$ No original, disponível em:

$<$ http://www.perseus.tufts.edu/hopper/text;jsessionid=A015E26CF73BAE15857CDCA0F6AD1BBA?doc=P

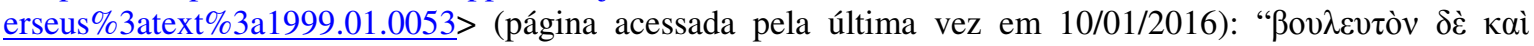

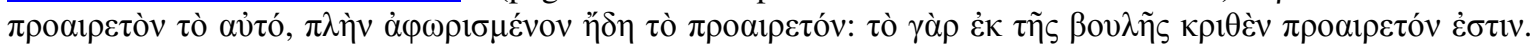

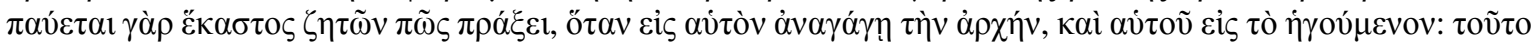

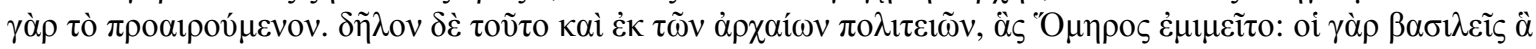

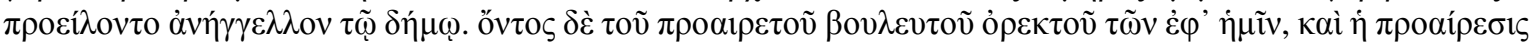

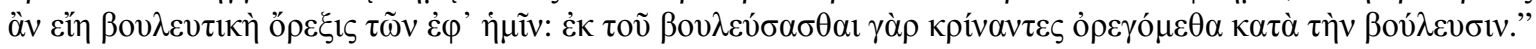
(grifos nossos)
} 
Nesta toada, mencionamos que o marco inicial da referida busca poderia ser historicamente fincado na Metafísica aristotélica, ou melhor, naquela ciência (no sentido de

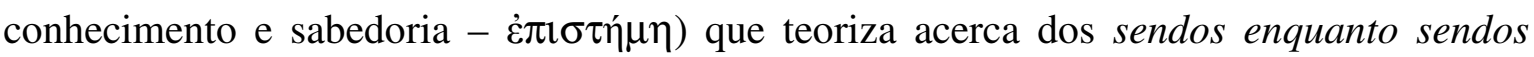
( $\tau$ ò ôv $\tilde{\eta}$ ôv) e as propriedades que lhe competem enquanto tal

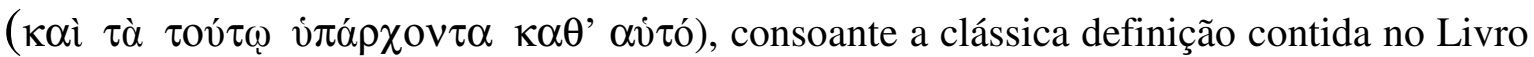
4 (Г), fragmento 1003a, linhas 20-21, da Metafísica de Aristóteles.

Mas como também já havíamos indicado, Aristóteles foi expresso ao afirmar que o ser, este 'algo' que é evidente e fundamento em si (e, mais contemporaneamente, entendido como evidente com-sigo e com-outrem ${ }^{97}$ - sic), que sempre a nós se presentifica já dado (quando se ouve o ser-passado) e projetado (quando se imagina e insere o ser-futuro) ${ }^{98}$, nos

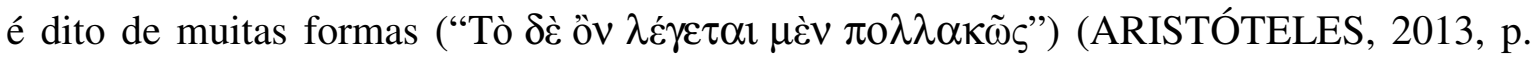
$130)^{99}$.

E este acaba inclusive por consubstanciar o grande problema do ser, tal como seminalmente visualizado por Aristóteles:

[...] o drama do ser aristotélico não está no pollachōs, está no leghetai. Que o digamos de um ou muitos modos, o ser é algo que se diz. [..] torna-se problema filosófico apenas no momento em que falamos sobre ele. Antes, é justamente o fato de falarmos sobre ele que o torna ambíguo e polivalente. $\mathrm{O}$ fato de que a polivalência possa ser reduzida não nos priva de tomarmos conhecimento apenas através de um dizer. O ser, enquanto pensante, se nos apresenta desde o início como um efeito da linguagem.

97 "O ser, em cuja evidência não-eliminável nos abrimos para cada interrogação que lhe diz respeito, é o Fundamento de si mesmo.” (ECO, 1998, p. 25).

98 "Por que há o ser de preferência ao nada? Porque sim. Esta é uma resposta a ser levada com a máxima seriedade, não como um dito espirituoso. O próprio fato de que podemos fazer a pergunta [...] significa que a condição de toda pergunta é que o ser exista. O ser não é um problema de senso comum [...] porque é a própria condição do senso comum." (ECO, 1998, p. 23, grifos no original). E conclui o professor italiano, em apertada síntese: "O ser existe antes mesmo que se fale dele [...]. O ser não nos diz nunca 'não', senão por metáfora nossa." (ECO, 1998, p. 25).

$99 \mathrm{Na}$ realidade, a afirmação acerca da multiplicidade dos sentidos do ser é feita em diversas passagens da Metafísica, como ocorre, por exemplo, nos seguintes fragmentos: 1003b, linha 5; 1026a, linhas33-34; 1026b, linha 2 ; 1028a, linha 1 . 
No momento em que paramos à sua frente, o ser suscita interpretação; no momento em que podemos falar sobre ele, este já é interpretado. Não há mais nada a fazer. (ECO, 1998, p. 27, grifos no original).

Por meio de suas elucubrações, sem reduzir ou mitigar aquilo que Eco denomina como o "potencial dramático" do ser (ECO, 1998, p. 26), Aristóteles tencionou de fato tornalo um pouco mais palatável, por assim dizer, teorizando que existiriam quatro significados fundamentais para o ser.

Para Aristóteles, os muitos modos pelos quais o ser se nos apresenta:

[...] se reduziriam a quatro, e seria possível controlá-los. O ser se diz (i) como ser acidental [...]; (ii) como verdadeiro, [...]; (iii) como potência e ato, [...]; (iv) enfim, o ser se diz como ens per se, ou melhor, como substância. (ECO, 1998, p. 26).

Com efeito, os quatro modos fundamentais do ser são expressamente mencionados no Livro $\Delta$ (fragmento 1017a, linhas 7-35; fragmento $1017 \mathrm{~b}$, linhas 1-9) e no Livro E (fragmento 1026a, linhas 33-37; fragmento 1026b, linhas 1-4) da Metafísica.

Os quatro modos fundamentais de ser também são mencionados por Franco Volpi ${ }^{100}$ ao tratar da influência que a doutrina de Franz Brentano teve para a leitura e interpretação feitas por Heidegger acerca de Aristóteles (principalmente a obra de Brentano denominada Von der mannigfachen Bedeutung des Seienden nach Aristoteles, publicada inicialmente em 1862):

Brentano affronta la dottrina aristotelica della plurivocità dell'ente a partire dai quattro significati fondamentali di quest'ultimo: (1) il primo significato è quello dell'ente per sé (on hath'hauto) e dell'ente per accidente (on kata symbebekos), [...]. (2) Il secondo significato è quello dell'ente come vero (on hos alethes), [...]. (3) Il terzo significato è quello dell'ente secondo la potenza e secondo l'atto (on dynamei kai energeiai), [...]. (4) Infine, il quarto e ultimo significato fondamentale è quello secondo le figure delle categorie (on kata ta schemata ton kategorion), [...]. Per Brentano, che [...] interpreta l'ontologia aristotelica come dottrina della sostanza (la prima delle categorie), è quest'ultimo il significato fondamentale

${ }^{100}$ VOLPI, Franco. Heidegger e Aristotele. - Bari/Itália: Editori Laterza, 2010. 
dell'essere più importante tra i quattro elencati. (VOLPI, 2010, p. 59, grifos no original)

Em vista do objeto desta Dissertação, deixaremos um tanto de lado as discussões

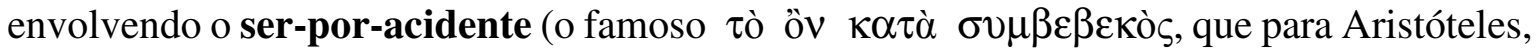
em função mesmo da sua acidentalidade, não poderia constituir qualquer tipo de ciência, seja ela teórica, poiética ou prática ${ }^{101}$, a ponto de o Estagira afirmar que o ser-acidental "revelase como algo próximo ao não-ser" ${ }^{\text {102 }}$ ), o ser-em-si (normalmente ${ }^{103}$ associado por Aristóteles à substância ou à essência, que para ele seria o ser por excelência ${ }^{104}$, o sentido primordial do $\operatorname{ser}^{105}$, tal como defendido até mesmo por Franz Brentano, como visto acima, a ponto de a ontologia aristotélica ser denominada de usiologia ${ }^{106107108}$, muito embora tenhamos para conosco que uma análise meramente categorial da existência peca exatamente

101 "Dado que o ser tem múltiplos significados, devemos tratar em primeiro lugar do ser como acidente e demonstrar que dele não existe nenhuma ciência. Temos prova disso no fato de que nenhuma ciência se ocupa dele: nem a ciência prática, nem a ciência poiética, nem a ciência teórica." (ARISTÓTELES, 2013, p. 273274).

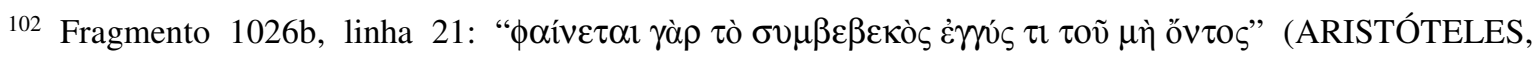
2013, p. 274).

${ }^{103}$ Somos obrigados a dizer que normalmente Aristóteles associa o ser-em-si (ou por-si) com a substância pois a questão não é apresentada univocamente na Metafísica. De fato, como mencionado por Giovanni Reale no ensaio introdutório por ele feito à sua tradução da Metafísica: "Como exemplo de ser por si Aristóteles indica, na maioria dos casos, a substância; em $\Delta 7$, todavia, ele apresenta todos as categorias como ser por si: além da essência ou substância, também a qualidade, a quantidade, a relação, o agir, o padecer, o onde e o quando. Com efeito (diferentemente do que se verifica na filosofia medieval), em Aristóteles as outras categorias além da substância são algo bem mais sólido do que o ser acidental e fortuito, enquanto são, embora subordinadamente à substância, fundamento de segunda ordem dos outros significados do ser." (ARISTÓTELES, 2005, p. 68, grifos no original).

${ }^{104}$ Fragmento 1028a, linhas 30 e 31:

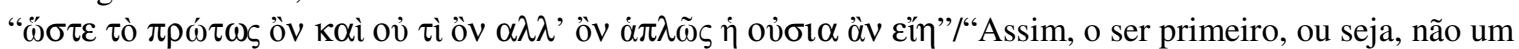
ser particular, mas o ser por excelência é a substância.” (ARISTÓTELES, 2013, p. 286-287).

${ }^{105}$ Ao comentar exatamente o fragmento 1028a, linhas 2-4, Giovanni Reale afirma que "causas e princípios do ser enquanto ser é expressão que só pode significar as causas e os princípios da substância" (ARISTÓTELES, 2011, p. 323).

${ }^{106}$ Ainda comentando o fragmento 1028a, linhas 2-4, Giovanni Reale arremata que, em suma "mais uma vez nos encontramos diante de um redimensionamento essencialmente usiológico da ontologia aristotélica: [...]." (ARISTÓTELES, 2011, p. 323).

${ }^{107}$ Como afirmado por Abbagnano ao comentar acerca do caráter central e definidor que a substância tem para Aristóteles: "O princípio da contradição, tomado no seu alcance ontológico-lógico, conduz diretamente a determinar o ser enquanto tal que é o objeto da metafísica. Este ser é a substância. A substância é o ser por excelência, o ser que é impossível que não seja e portanto é necessariamente, o ser que é primeiro em todos os sentidos." (ABBAGNANO, 2006, p. 156, grifos no original).

108 “[...] fica claro que a ontologia aristotélica deverá, fundamentalmente, centrar-se sobre a substância, que é o princípio relativamente ao qual todos os outros significados subsistem. Justamente nesse sentido dizemos que a ontologia aristotélica é, fundamentalmente, uma usiologia." (ARISTÓTELES, 2005, p. 65, grifos no original). 
ao dar mais valor ao ser-predicação e ao ser-definição ${ }^{109}$, necessitantes per se por buscarem uma essência constante, persistente e necessária do $\operatorname{ser}^{110}$, ao invés de tentar aprofundar o que seria o ser-existencial que ora procuramos buscar o salto originário (Ur-sprung) para sua transcendência, via possibilidade) e o ser-verdadeiro (que, sob nosso ponto de vista, encontra-se mais próximo da verdade enquanto intuição revelada do que uma adaequatio escolástica).

Mas o que seria então o ser-potência?

Sem querer aqui adentrar em longuíssimas discussões do tipo escolástico acerca do que se pode aferir da ideia do ser-potência, podemos concentrar a discussão na definição apresentada por Aristóteles no fragmento 1019a, linhas 15-16 (que é usada como base para todas as discussões que se seguem posteriormente).

Com efeito, o Estagira afirma que a potência "significa o princípio de movimento ou de mudança que se encontra em outra coisa ou na própria coisa enquanto outra"

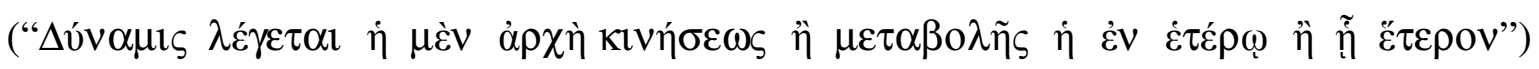
(ARISTÓTELES, 2013, vol. II, p. 224-225).

\footnotetext{
${ }^{109}$ Novamente Franco Volpi, ao analisar o estudo feito por Brentano acerca do ser-categorial, leciona que haveriam três interpretações correntes acerca do que seriam as categorias aristotélicas: (i) a primeira, defendida por Ch.A. Brandis, L. Strümpell e por E. Zeller, "vede nelle categorie non dei concetti veri e propri, ma solamente la struttura predicativa entro la quale tutti i concetti reali debbono essere ordinati" (VOLPI, 2010, p. 26); (ii) a segunda interpretação, apoiada por A. Trendelenburg, F. Biese e T. Waitz, "considera infatti le categorie come concetti non nel senso di rappresentazioni concettuali, di concetti presi separatamente, bensì nel senso logico" (VOLPI, 2010, p. 26); e (iii) a terceira interpretação, apoiada por H. Bonitz, C. Ritter e Hegel, aceita, na linha da segunda interpretação, que as categorias não são a estrutura do conceito, mas o conceito em si, mas acaba por "negare che le categorie siano meri predicati e che la loro tavola sia ricavata da una considerazione exclusivamente logico-grammaticale" (VOLPI, 2010, p. 26). Qualquer que seja a interpretação que se adote, é inegável o caráter lógico-proposicional que o ser-categorial possui, tornando-o refém do cálculo proposicional e da lógica necessitante ("il linguaggio della necessità" mencionado por Abbagnano). Tanto assim que Volpi é expresso ao afirmar que "Brentano ritiene possibile determinarne rigorosamente il criterio, darne cioè una 'prova deduttiva', in base a una divisione dell'essere" (VOLPI, 2010, p. 27, grifos nossos)

${ }^{110}$ Obviamente estamos tratando da homonímia, apresentada por Aristóteles, que existiria entre a substância (ovol $\alpha$ ) e a ideia de essência, mencionada exemplificativamente no fragmento 1017b, linhas 21 e 22, onde o Estagira apresenta o quarto e fundamental significado da substância: "além disso, chama-se substância de cada

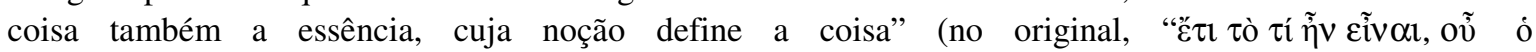

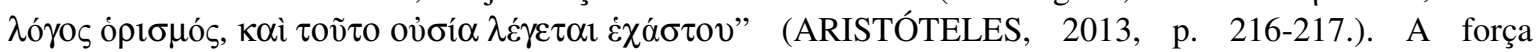
necessitante que Aristóteles concedia à ideia de essência encontra-se na própria forma por ele utilizada para denominar a essência ao longo da Metafísica ( $\tau$ ò $\tau$ í $\tilde{\eta} v$ eĩvol). Como leciona Abbagnano: "A expressão que Aristóteles se serve para definir a substância é: aquilo que o ser era (to ti en enai, quod quid erat esse). Nesta fórmula, a repetição do verbo ser exprime que a substância é o princípio constitutivo do ser como tal; e o imperfeito (era) indica a persistência e a estabilidade do ser, a sua necessidade. A substância é o ser do ser: o princípio pelo qual o ser o é necessariamente." (ABBAGNANO, 2006, p. 157-158, grifos no original)
} 
Para melhor explicar o que seria o referido princípio de movimento e mudança

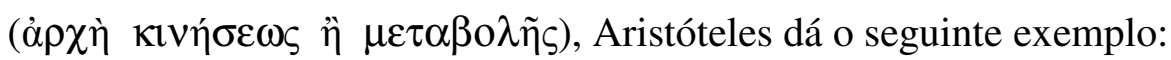

\begin{abstract}
A arte de construir, por exemplo, é uma potência que não se encontra na coisa construída; mas a arte de curar, que também é uma potência, pode encontrar-se também no que é curado, mas não enquanto é curado. (ARISTÓTELES, 2013, p. 225).
\end{abstract}

Muito embora entendamos que este princípio de movimento e mudança vai para além do contemporâneo movimento físico-newtoniano, temos de qualquer maneira que o conceito aristotélico de potência (mais próximo da ideia de potencialidade ou virtualidade) não se ajusta bem ao conceito de ser-possível que pretendemos expor nesta Dissertação.

Nesta linha, já antecipamos que nossa ideia de poder-ser é tratá-lo como inerentemente problemático e aberto ao risco e perigo (sem tentarmos salvar qualquer fenômeno para tanto), à medida que o ser-possível está sobremaneira referenciado na possibilidade existencial de não ser, isto é, naquele ser-risco (a liberdade) (com)partilhado pelo Dasein que pode ser ou não ser, enquanto tal, e sempre com a possibilidade de deixar de ser, dependendo apenas de uma decisão antecipadora para tanto (que, na nossa concepção, é o verdadeiro fundamento do fenômeno ético, jurídico e da própria liberdade em si).

Tal como afirmado por Abbagnano, a ideia de possibilidade é uma das características mais salientes da filosofia contemporânea, mas faz-se mister uma melhor definição terminológica acerca do tema (ABBAGNANO, 1956, p. 58).

Assim:

Poichè è necessario partire da qualche precisazione terminologica, intendiamo per possibile ciò che può essere o non essere ed è solo come tale. In questa accezione terminologica, il possibile non si connette necessariamente col mutamento, col divenire, col progresso ecc., $\mathrm{e}$ in generale con una concezione dell'essere come 
movimento. L'immobilità stessa è un possibile, se, nonostante che sia tale, può non esserlo. (ABBAGNANO, 1956, p. 58). ${ }^{111}$

E tornando ainda mais clara a sua posição acerca do caráter inerentemente dual e problemático da possibilidade (ser e não ser, ao mesmo tempo), novamente Abbagnano:

\begin{abstract}
Il possibile si riferisce, in altri termini, ad ogni condizione, stato o modo d'essere che comunque includa indeterminazione, instabilità, incertezza, precarietà, caducità, pericolo o rischio. Dall'altro lato, esso non esclude neppure la determinazione, la stabilità, la certezza, ecc., se queste condizioni o stati non vengono assolutizzati e considerati irremovibili. Esso esclude soltanto e proprio questa assolutizzazzione, cioè l'irrigidimento ontologico di tali condizioni o stati in modi d'essere privi d'interna problematicità. Il possibile esprime infatti la struttura di ogni condizione problematica, cioè di ogni condizione nella quale o rispetto alla quale possa comunque radicarsi un dubbio, una domanda, un problema che si giustifichi come tale. (ABBAGNANO, 1956, p. 58-59).
\end{abstract}

Deste modo, e no que respeita particularmente ao ser-potência ${ }^{112}$, entendemos que é importante superarmos a própria narrativa aristotélica do ser-possível, dada a sua inerente vinculação ao (e derivação do) ser-necessário (do qual, no final, se torna mero expediente auxiliar, e não uma modalidade independente em si).

Com efeito, tal dependência se torna manifesta quando analisamos algumas passagens específicas da Metafísica, pelas quais torna-se claro que Aristóteles considerava

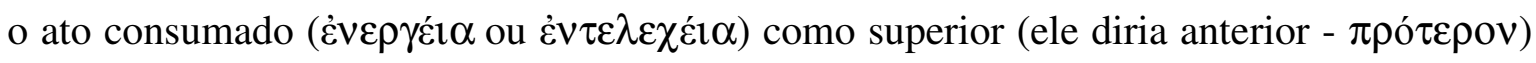
ao ser-potência $(\delta v v \alpha \mu \imath \varsigma)$, sendo que nos parece claro que qualquer ato consumado necessariamente é ou foi, e portanto, encontra-se intrinsicamente derivado do (e atrelado ao) ser-necessário.

\footnotetext{
${ }^{111}$ Muito embora ousamos afirmar aqui temos a impressão de que o Professor Abbagnano trata o movimento

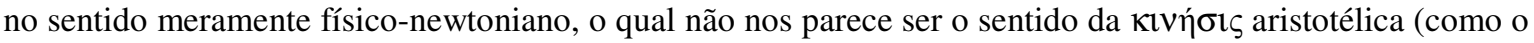
próprio excerto da nota 180 acima presentifica - em que o homem é capaz de curar e ser curado - ou quando dizia que não se podia encontrar o ser-necessário caso houvesse um movimento voltado à deliberação -

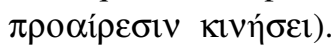

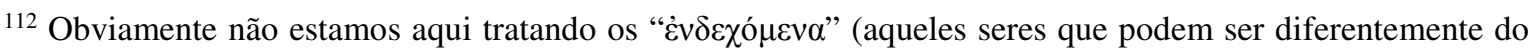
que são), já mencionados, como ser-potência.
} 
Muito embora no fragmento 1046a (linhas 29 et seq.) o Estagira conteste aqueles (os Megáricos) que "sustentam que só existe potência quando existe ato, e que quando não existe ato também não existe a potência" (ARISTÓTELES, 2013, vol. II, p. 401), um pouco mais a frente nos parece claro que ele o faz apenas para sustentar que um difere do outro, e nada mais.

E apoiamos esta ideia pois, como já há muito consolidado entre todos os comentadores (Cf. ABBAGNANO, 2006, p. 164 et seq.), Aristóteles não concebe que o serpotência possa existir independentemente do ato consumado, sempre derivando o serpotência do ato em si. No fragmento 1047 b (linhas 3-6) ele inclusive afirma que se "algo é em potência enquanto se lhe segue o ato, é evidente que não pode ser verdade quando se diz que determinada coisa pode ser, mas não existirá nunca, porque nesse caso não se poderia falar de coisas que não podem ser" (ARISTÓTELES, 2013, vol. II, p. 405).

Em outras palavras: se for verdade que o ser-potência deriva do ato, então não há como ser verdade que o ser-potência jamais poderá existir se um dia, não importa quando, o ser-potência de fato não for.

Se esta ideia não bastasse, Aristóteles afirma peremptoriamente em dois outros fragmentos que "é evidente que o ato é anterior à potência e a todo princípio de mudança" (fragmento 1051a, linhas 2-3) (ARISTÓTELES, 2013, p. 425) ${ }^{113}$, de modo que o "ato, portanto, é melhor [do que a potência]" (ARISTÓTELES, 2013, p. 427).

Entendemos que não há motivo para continuarmos aprofundando esta questão em função mesmo dos objetivos desta Dissertação. Entretanto, temos para conosco que tratar o poder-ser como ser-potência, no sentido aristotélico, acaba por ocasionar aquele “enrijecimento ontológico" tratado por Abbagnano, e que já mencionamos acima, o qual culmina por absolutizar condições ou modos do ser, impedindo de trazer a lume (para a clareira do ser - Lichtung - como diria Heidegger) aquelas condições que por acaso carreguem consigo a indeterminação, a instabilidade, a incerteza, a precariedade e o risco

\footnotetext{
${ }^{113}$ Apenas a título de completude, importante ressaltarmos que Aristóteles não tinha uma visão meramente temporal da ideia de "anterior" ( $\pi \rho$ ó $\varepsilon \rho \rho v)$, como ele deixa bem claro no Livro $\Delta$, capítulo 11. Cf. ARISTÓTELES, 2013, p. 220 et seq.
} 
que, no final do dia, na realidade é ontologicamente inerente à existência (e a todos os processos decisionais).

Como leciona Abbagnano, a posição aristotélica acerca do ser-potência, de fato:

[...] è soltanto l'introduzione surrettizia della categoria del possibile in una categoria eterogenea che la esclude. Una potenzialità che non si è realizzata non era una potenzialità giacchè l'unico fondamento per dichiararla tale sarebbe appunto la sua attualizzazzione. Se questa attualizzazzione manca, manca ogni fondamento possibile per affermare la sua preformazione implicita o la sua predeterminazione, e per distinguerla da una non-potenza. (ABBAGNANO, 1956, p. 60 , grifos no original).

Feitas estas considerações acerca do ser-possível enquanto ser-potência (uma mera espera pela atualização, uma virtualidade travestida de possibilidade em si), faremos agora um breve apanhado do que seria o estudo das modalidades, tradicionalmente denominado de lógica modal, para que possamos entender o segundo significado fundamental do serpossível e para, ao final, iniciarmos a análise da possibilidade sob a ótica da existência/presença (Dasein).

\subsection{Síntese histórica da lógica modal e a possibilidade meramente modal}

As pesquisas em torno das modalidades ${ }^{114}$, desde a tradição ligada à lógica aristotélico-escolástica, são basicamente caracterizadas como o estudo das "diferenças da predicação, ou seja, os diferentes modos como um predicado se refere a um sujeito num enunciado." (ABBAGNANO, 2007, p. 788).

\footnotetext{
${ }^{114}$ Segundo o Dicionário Aurélio, a modalidade, dentro do estudo da linguística, poderia ser referenciada como sendo uma "categoria gramatical expressa, ger., por meio de modais [...], ou ainda em partículas independentes do verbo, para a expressão da atitude do falante com relação a crenças, opiniões, julgamentos que perpassam seu discurso", sendo que a estruturação do seu estudo lógico advém da "tradição aristotélico-tomista", podendo ser referenciada como o "caráter das proposições segundo o qual a relação que elas exprimem se enuncia como fato, ou é declarada possível ou impossível, necessária ou contingente". Cf. FERREIRA, Aurélio Buarque de Holanda. Novo Aurélio Século XXI: o dicionário da língua portuguesa. $-3^{\mathrm{a}}$ ed. Rio de Janeiro: Nova Fronteira, 1999, p. 1350 (verbete modalidade, acepções 3 e 4), grifos nossos. O Dicionário Houaiss afirma que a modalidade "na lógica clássica de matriz aristotélica" seria a "classificação das proposições ou juízos que avalia a possibilidade, a impossibilidade, a necessidade ou a contingência presentes na atribuição de um predicado a um sujeito". Cf. HOUAISS, Antônio. Grande Dicionário Houaiss da língua portuguesa. Disponível em <http://houaiss.uol.com.br/> (grifos nossos). Acessado pela última vez em 10/01/2016.
} 


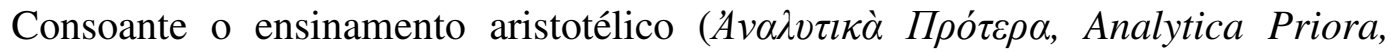
Analíticos Anteriores I, 8, 29 b 29), uma coisa seria pertencer, outra pertencer por necessidade e outra poder pertencer, "visto que muitas pertencem, mas não por necessidade, outras não pertencem nem por necessidade nem simplesmente, mas podem pertencer" (ABBAGNANO, 2007, p. 789).

Desta feita:

\begin{abstract}
Aristóteles distingue: 1) o pertencer puro e simples de um predicado ao sujeito; 2) o pertencer necessário; 3) o pertencer possível. Mais tarde (por obra dos comentadores de Aristóteles), a segunda e a terceira forma de predicação passaram a ser chamadas de modos; e passara, a ser chamados de 'proposições modais' os enunciados nos quais entravam as modalidades do necessário e do possível, se bem que em alguns autores o conceito de 'modo' se estende a tal ponto que compreende aquilo que hoje chamaríamos de 'modalidades epistêmicas', como saber que, ser duvidoso, ser indubitável etc." (ABBAGNANO, 2007, p. 789).
\end{abstract}

No que diz respeito ao "pertencer possível”, e apenas para fins de esclarecimento e completude, há uma passagem da Metafísica em que Aristóteles, ao conceituar o que seria o ser-possível, deixa claro o seu alinhamento com a teoria que apresentamos acima relativamente à anterioridade e superioridade (ontológicas) que o Estagira confere ao ato quando compara-o à potência, ao mesmo tempo em que, conjuntamente com os estudos

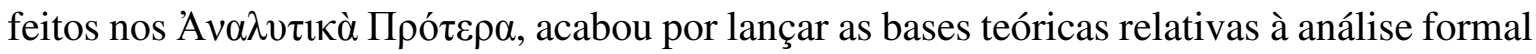
das proposições modais.

Trata-se especificamente do fragmento 1019b, linhas 22-33, do qual gostaríamos de reproduzir alguns excertos:

\footnotetext{
Impossível é aquilo cujo contrário é necessariamente verdadeiro: [...]. Tem-se o contrário do impossível, isto é, o possível quando não é necessário que o contrário seja falso: [...]. Portanto, o possível, como dissemos, significa (a) num sentido, o que não é necessariamente falso, (b) noutro sentido, o que é verdadeiro; (c) num terceiro sentido, o que pode ser verdadeiro. (ARISTÓTELES, 2013, p. 229230). ${ }^{115}$
}

115 Contudo, Aristóteles salienta que todos estes sentidos relacionados ao ser-possível ( $\tau \alpha \quad \delta \dot{\varepsilon}$ $\lambda \varepsilon \gamma o ́ \mu \varepsilon v \alpha \kappa \alpha \tau \alpha \grave{\alpha} \delta$ v́ $\alpha \mu \imath v)$ na realidade não teriam a ver com o conceito de potência em si, reduzível que é 


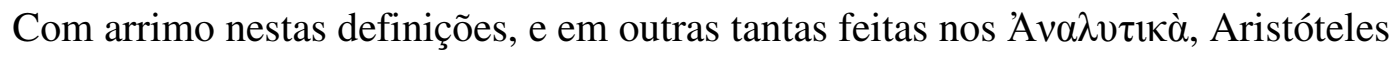
inaugurou o estudo sistemático de conceitos tais como proposições universais, particulares, afirmações, negações, contradições, contrariedades, sub-contrariedades e todo arsenal teórico criado para demonstrar a validade dos silogismos lógicos, estudo que, por séculos a fio, foi muito valorizado pela própria jusfilosofia, em vista mesmo de sua estética (ou narrativa) matemático-objetivante.

Não pretendemos detalhar todo o caminho perseguido pela filosofia em torno das categorias, alcance e limitações da lógica modal, envolvendo a classificação das sentenças universais e particulares, suas contradições, contrariedades, regras do cálculo proposicional, sistemas de completude formal, etc. ${ }^{116}$

De qualquer maneira, e apenas para uma melhor contextualização, contemporaneamente o estudo das modalidades (proposições modais) são usualmente classificadas como: (i) assertivas, por meio das quais exprime-se um mero fato (por exemplo, “São Paulo é uma cidade grande", em que não se está afirmando se o enunciado é verdadeiro ou não, apenas afirma-se algo); (ii) aléticas, pelas quais podemos investigar, ainda que $a$ posteriori, a veracidade do enunciado (por exemplo, "é possível que chova hoje" ou "certamente a Terra é um planeta"). Tradicionalmente são divididas entre modalidades/proposições apodícticas - quando os enunciados são cientificamente demonstráveis, exprimam algo que seja o caso necessariamente, ou que, caso contrário, sejam impossíveis - e as modalidades/proposições ditas problemáticas - quando os enunciados tratam de possibilidades/contingências); (iii) temporais, quando o núcleo da enunciação parte da e foca na temporalidade da ação (por exemplo, "sempre foi o caso de as folhas estarem verdes em abril"); e (iv) epistêmicas e as doxáticas, pelas quais se enuncia

ao primeiro sentido de potência: "Estes significados do possível não se referem às noções de potência. Ao contrário, todos os significados que se referem à potência implicam uma relação com o primeiro significado de potência, isto é, potência como princípio de mudança em outra coisa ou na própria coisa enquanto outra." (ARISTÓTELES, 2013, p. 231).

116 Para tanto, além dos textos nesta citados, sugerimos a seguinte leitura complementar: (i) BASTOS, Cleverson Leite et al., Lógica modal: aspectos históricos, v.1. Curitiba: Champagnat, 2012; (ii) CHELLAS, Brian F., Modal logic: an introduction. Cambridge: Cambridge University Press, 1999; (iii) COSCARELLI, Bruno Costa. Introdução à lógica modal. São Paulo: Biblioteca 24horas, 2012; (iv) JUBIEN, Michael. Possibility. Oxford: Oxford University Press, 2011; (v) PLATINGA, Alvin. The nature of necessity. Oxford: Oxford University Press, 2010; (vi) PRUSS, Alexander R. Actuality, possibility and worlds. Nova York: The Continuum International Publishing Group, 2011; (vii) TOOLEY, Michael (editor). Analytical Metaphics (a collection of essays). Necessity and possibility: the metaphysics of modality. Nova York: Routledge, 2011. 
um conhecimento ou uma crença ("é de sabença geral que falta de leitura é péssimo para o desenvolvimento da criança”, "eu acredito que este é o melhor caminho a se tomar”).

De qualquer maneira, grande parte da lógica contemporânea pode ser encarada como uma linguagem axiomatizada criada artificialmente para demonstrar cientificamente a validade de determinada(s) proposição(ões) aléticas ou de um conjunto delas, dentro do que houver de mais cientificamente possível à disposição, sendo a lógica modal um dos campos que mais se desenvolveram no último século neste sentido.

E por sua própria artificialidade, em que sua robustez de fato encontra-se calcada no seu aspecto estritamente formal, é que propomos avançar para além da simples amarração lógico-proposicional de sentenças criadas pela lógica modal, ainda quando referentes ao conceito de possibilidade.

Muitas vezes os sistemas formais criados nem ao menos correlacionam-se com alguma verdade existencial ou referência extensional específica, valendo per se, dentro dos axiomas, esquemas e teoremas criados dentro e para a própria linguagem lógica assim criada: um conjunto de sentenças lógico-proposicionais que retira sua verdade basicamente (para não dizer somente) do princípio da não incongruência que é inerente a qualquer sistema matemático - uma verdade, em suma, meramente formal ${ }^{117}$.

\footnotetext{
${ }^{117}$ Mais uma vez nos apoiaremos nos ensinamentos de Nicola Abbagnano para apreendermos de maneira mais holística o que caracterizaria o ser-verdade pois entendemos que tais ensinamentos são essenciais, embora laterais para os fins desta Dissertação, para prosseguirmos: "É possível distinguir cinco conceitos fundamentais de V[erdade].: $\mathbf{1}^{\circ}$ a V[erdade]. como correspondência; $2^{\circ}$ a V[erdade]. como revelação; $3^{\circ}$ a V[erdade]. como conformidade a uma regra; $4^{\circ}$ a $V\left[\right.$ erdade]. como coerência; $5^{\circ}$ a V $[$ erdade]. como utilidade. [...] $1^{\circ} \mathrm{O}$ conceito de $\mathrm{V}$ [erdade]. como correspondência é o mais antigo e divulgado. Pressuposto por muitas das escolas pré-socráticas, o primeiro a formulá-lo explicitamente foi Platão, na definição do discurso verdadeiro feito em Crátilo: 'Verdadeiro é o discurso que diz as coisas como são; falso é aquele que as diz como não são' (Crat., 385b; v. Sof., 262 e; Fil., 37c). Por sua vez, Aristóteles dizia: 'Negar aquilo que é e afirmar aquilo que não é, é falso, enquanto afirmar o que é e negar o que não é, é a verdade' (Met., IV, 7, $1011 \mathrm{~b} 26$ ss.; v. V, 29, 1024b25). Aristóteles enunciava também as duas teses fundamentais dessa concepção de verdade. A primeira é que a V[erdade]. está no pensamento ou na linguagem, não no ser ou na coisa (Met., VI, 4, 1027b25). O segundo é que a medida da V[erdade]. é o ser ou a coisa, não o pensamento ou o discurso; de modo que uma coisa não é branca porque se afirma com V[erdade]. que ela assim é, mas afirma-se com V[erdade]. que ela é branca porque é (Met., IX, 10, 1051b5). [...] Ademais, a coexistência de dois conceitos de V[erdade]. não é rara. Muitas vezes a teoria da correspondência é acompanhada pela teoria da V[erdade]. como manifestação ou revelação. [...], Tomás de Aquino, retomando uma definição de Isaac Ben Salomon, do século IX, define a V[erdade]. como 'adequação entre o intelecto e a coisa' (S.Th., I, q. 16, a.2; Contra Gent., I, 59, De ver., q. I, a.I), mas, ao mesmo tempo que mantém, em relação ao homem, a tese aristotélica de que as coisas - e não o intelecto - são a medida da V[erdade]., inverte essa tese no que diz respeito a Deus: [...]. $2^{\circ}$ A segunda concepção fundamental de V[erdade]. é a que a considera com o revelação ou manifestação. Tem duas formas fundamentais: uma empirista e outra metafísica ou teológica. A forma empirista consiste em admitir que a V[erdade]. é o que se revela imediatamente ao homem, sendo, portanto, sensação, intuição ou
} 
De qualquer maneira, e apenas para que possamos tentar superar esta narrativa logicista e formalista (enquanto parte daquilo que Abbagnano cunhou como sendo a "linguagem da necessidade"), gostaríamos de ressaltar que contemporaneamente é possível identificarmos diversos tipos de sistemas lógico-proposicionais envolvendo a lógica modal, todos fundamentados em axiomas próprios e gerados pelos modos os mais diversos possíveis ao estabelecerem sua semântica específica.

Nesta toada, poderíamos mencionar o sistema lógico K (em homenagem a Saul Kripke), o sistema B (em homenagem a Luitzen Egbertus Jan Brouwer) e o sistema S5 (proposto por Clarence Irving Lewis e Cooper Harold Langford), sendo que a maioria de tais sistemas utilizam funtores sintáticos muito aproximados, variando basicamente na forma em que articulam semanticamente suas proposições.

Apenas a título de exemplificação, o sistema S5 baseia-se semanticamente na distinção feita por Leibniz acerca do que seria a necessidade quando comparada com a

fenômeno. A forma metafísica ou teológica afirma que a V[erdade]. se revela em modos de conhecimento excepcionais ou privilegiados, por meio dos quais se torna evidente a essência das coisas, seu ser ou o seu princípio (Deus). [...] Heidegger insistiu no caráter de revelação ou de descobrimento da V[erdade]., recorrendo mesmo à etimologia da palavra grega. Assim, por um lado insistiu no nexo estreito entre o modo de ser da V[erdade]. e o modo de ser do homem, o ser-aí, porquanto só ao homem a V[erdade]. pode revelar-se e revelase (Sein und Zeit, § 44). Por outro lado, insistiu na tese de que o lugar da V[erdade]. não é o juízo, e que a $\mathrm{V}$ [erdade]. não é uma revelação de caráter predicativo, mas consiste no ser descoberto do ser das coisas, ou das próprias coisas, e no ser descobridor do homem (ibid., §44b; v. Vom Wesen des Grundes, I, trad. it., p.20). Heidegger, porém, também ressaltou o fato de que cada descobrimento do ser, por ser parcial, também é um cobrimento dele; [...]. $3^{\circ}$ A terceira concepção considera a V[erdade]. como conformidade com uma regra ou um conceito. O primeiro a enunciar essa noção foi Platão. 'Ao tomar como fundamento o conceito que considero mais sólido, tudo o que me pareça estar de acordo com ele será por mim posto como verdadeiro, quer se trate de causas, quer se trate de outras coisas existentes; o que não me pareça de acordo com ele será por mim posto como não verdadeiro.' (Fed., 100a) [...] Agostinho afirmava que 'acima de nossa mente há uma lei chamada V[erdade].' e que nós podemos julgar todas as coisas em conformidade com essa lei, que no entanto escapa a qualquer juízo (De vera rel., 30-31). [...] Rickert identificava o objeto do conhecimento com a norma à qual o conhecimento deve adequar-se para ser verdadeiro (Der Gegenstand der Erkenntnis, 1892). [...] $4^{\circ}$ A noção de V[erdade]. como coerência aparece no movimento idealista inglês da segunda metada do século XIX e é compartilhada por todos os que participaram desse movimento na Inglaterra e nos Estados Unidos. [...] A definição da V[erdade]. como utilidade pertence a algumas formas da filosofia da ação, especialmente o pragmatismo. Mas o primeiro a formulá-la foi Nietzsche: 'Verdadeiro em geral significa apenas o que é apropriado à conservação da humanidade. O que me faz perecer quando lhe dou fé não é verdadeiro para mim: é uma relação arbitrária e ilegítima do meu ser com as coisas externas (Wille zur Macht, ed. Kröner, 78, 507). Foi o pragmatismo que difundiu essa noção, defendida primeiramente por W. James.” (ABBAGNANO, 2007, p. 1182 et seq.) De qualquer maneira, não podemos olvidar que contemporaneamente as discussões acerca da verdade extrapolam os cinco principais tipos de verdade que a filosofia tende a reconhecer, muitas vezes mesclando-os como já salientado pelo próprio Abbagnano no excerto acima. Neste sentido, temos a verdade como forma de erro (do próprio Nietzsche), a verdade como abertura e evento do ser (característica da teoria de Heidegger) e a verdade como pertença e jogo (Gadamer). 
possibilidade. Neste sentido, podemos mencionar diretamente o magistério de Brian F. Chellas, por resumir os elementos mais básicos de uma lógica modal contemporaneamente pensada:

The system S5 is determined semantically by an account of necessity and possibility that dates to the philosopher Leibniz: a proposition is necessary if it holds at all possible worlds, possible if it holds at some. The idea is that different things may be true at different possible worlds, but whatever holds true at every possible world is necessary, while that which holds at at least one possible world is possible.

$[\ldots]$

We study modal logic in the context of a language of necessity and possibility.

The sentences of the languages are of the following forms:

$\mathrm{P}_{0}, \mathrm{P}_{1}, \mathrm{P}_{2}, \ldots$

$\mathrm{T}, \stackrel{\perp}{,} \neg \mathrm{A}, \mathrm{A} \wedge \mathrm{B}, \mathrm{A} \vee \mathrm{B}, \mathrm{A} \rightarrow \mathrm{B}, \mathrm{A} \leftrightarrow \mathrm{B}, \underline{\underline{\mathrm{A}}, \diamond \mathbf{A}}$

Sentences of the form $P_{n}$ (for $n=0,1,2, \ldots$ ) are atomic. $T$ is a constant for truth; $\perp$ is a constant for falsity. $\neg, \wedge, \vee, \rightarrow$, and $\leftrightarrow$ are signs of negation, conjunction, disjunction, conditionality, and biconditionality, respectively. $\square$ is the necessity sign; $\diamond$ is the possibility sign.

$[\ldots]$

According to the leibnizian idea, necessity is what is true at every possible world and possibility is what is true at some. Linguistically: a sentence of the form $\square \mathrm{A}-$ necessarily $\mathrm{A}$ - is true if and only if $\mathrm{A}$ itself is true at every possible world; and a sentence of the form $\diamond \mathrm{A}$ - possibly $\mathrm{A}$ - is true just in case $\mathrm{A}$ is true at some possible world.

The picture is of a collection of possible worlds - including our own, the real world - at which sentences of the language are variously true and false. [...].

In other words, the sequence $\mathrm{P}_{0}, \mathrm{P}_{1}, \mathrm{P}_{2}, \ldots$ interprets the atomic sentences by stipulating at which possible worlds they are true (and, by omission, at which they are false): $\mathrm{P}_{\mathrm{n}}$ is true at a possible world $\alpha$ if and only if $\alpha$ is in the set $\mathrm{P}_{\mathrm{n}}$.

More precisely, a model is a pair

$<W, P>$

in which $W$ is a set of possible worlds and $P$ abbreviates an infinite sequence $\mathrm{P}_{0}$, $\mathrm{P}_{1}, \mathrm{P}_{2}, \ldots$ of subsets $W$. (CHELLAS, 1999, p. 3 et seq.).

Ainda que transcrito a título de mera indicação propedêutica, o excerto acima torna evidente que a lógica modal de fato acaba por estudar conceitos próximos daqueles a que nos propusemos investigar para superar a dicotomia ser/dever-ser mediante uma análise do binômio necessidade/possibilidade. 
Contudo, em função dos caminhos que pretendemos continuar trilhando nesta Dissertação, não faremos aqui uma análise aprofundada de todos os elementos axiomáticos, sintáticos e semânticos envolvendo qualquer um dos sistemas atualmente existentes de lógica modal (muitos deles, reiteramos, de caráter estritamente matemático e de pouca aplicação para a conduta prática humana, ainda mais quando vinculada a uma análise das estruturas ontológicas da própria normatividade, enquanto simples ser-jurídico desde-jásempre-dado-deliberado).

Fomos compelidos a mencionar alguns elementos básicos da lógica modal por uma questão de completude e esclarecimento, de modo a lançarmos as pedras conceituais que, embora aparentemente insípidas em sua base socializante e pragmática (seja porque, no final, a teoria se mostra inerentemente ainda atrelada à "linguagem da necessidade", como ocorre no caso da teoria aristotélica da potência - em que a possibilidade é uma mera virtualidade - seja por trabalhar com conceitos meramente proposicionais e de caráter lógicodemonstrativo), podem ajudar a melhor compreender o alcance que pretendemos dar à possibilidade existencialmente considerada.

Ademais, os elementos de lógica modal acima detalhados também serão importantes para que possamos no próximo item apresentar as conclusões de Gerhard Schurz ao tratar das questões envolvendo a Guilhotina de Hume, sob uma perspectiva meramente modal (lógico-proposicional).

Afinal de contas, e como bem salientado por Chaïm Perelman e Lucie OlbrechtsTyteca, o que importa é tornar mais próxima a possibilidade de irmos para além de um mero formalismo proposicional, cerne da lógica modal, à medida que:

A lógica teve um brilhante desenvolvimento durante os cem últimos anos, quando, deixando de repisar velhas fórmulas, propôs-se analisar os meios de prova efetivamente utilizados pelos matemáticos. [...] Mas o resultado foi a limitação de seu campo, pois tudo quanto é ignorado pelos matemáticos é alheio à lógica formal. Os lógicos devem completar a teoria da demonstração assim obtida com uma teoria da argumentação. (PERELMAN, 1996, p. 11, grifos nossos). 
Com efeito, nossa posição vai na linha de que não é adequado assimilar a possibilidade meramente matemática (inerente a uma análise feita a partir de uma lógica modal, normalmente absorta dentro do conceito de verdade puramente formal - isto é, sem contradições, em que há plena e estrutural coerência normativa) para dentro de uma exposição que visa a entender o poder-ser enquanto núcleo do ser-normativo de maneira fenomenológico-existencial, constitutivamente argumentativo (i.e., não demonstrativo, na medida em que falta ao fenômeno jurídico a possibilidade de suas proposições serem falseáveis, socialmente e economicamente conflitantes além, é claro, de decisionalmente contraditórias.

Apenas para retomarmos um ponto tratado quando da análise da teoria do positivista von Ihering, tínhamos aquele "simples pensamento" mirando à ação prática, que seria o núcleo da norma jurídica.

Segundo teoria já consagrada em nossas escolas, a qual foca sobretudo no caráter comunicacional (ainda que geralmente proposicional do fenômeno jurídico), na norma seria possível encontrarmos não apenas um comando puro e simples, um mero querer, havendo ainda uma relação de poder e autoridade que seria manifestada concomitantemente à emanação do comando, além é claro de uma relação de subordinação, de aceitação relativamente ao referido comando.

Desta forma:

Os teóricos do direito fazem, a partir daí, uma diferenciação entre cometimento e relato. O núcleo do mando da norma jurídica se revela como uma imposição, um império, e ao mesmo tempo, apresentando um conteúdo específico nesse mando. A norma jurídica é um mando que determina algum conteúdo. $\underline{\mathbf{O} \text { mando pode ser }}$ compreendido como sendo o caráter de cometimento da norma. $O$ conteúdo específico, a matéria, o tema, o objeto desse mando, é o relato que a norma exprime. (MASCARO, 2013, p. 81, grifos nossos).

O cometimento normativo, a relação meta-complementar ou institucionalizada entre autoridade e sujeito, se expressa verbalmente por meio de operadores linguísticos como: é proibido, é vedado, é facultado, é obrigatório, é permitido, deve-se, poderá, será, os quais podem estar explícitos ou implícitos (às vezes a norma apenas descreve uma ação-tipo e lhe atribui uma sanção: o caráter 
proibitivo está implícito). O cometimento pode expressar-se também analogicamente, por modos não verbais: o olhar silencioso da multidão, reprovando o comportamento de um adulto que espanca uma criança na rua. (FERRAZ JÚNIOR, op. cit., p. 117, grifos no original).

Todavia, mesmo os referidos "operadores linguísticos" Professor Tércio no excerto acima nada mais são que análises meramente modais entre o sujeito e o predicado (tal como classicamente definidos), o primeiro usualmente consubstanciado na ideia de "operadores do direito" (que mais nos parecem sacerdotes de ritos e mitos, como já deixamos transparecer ao longo desta), e o segundo como seu objeto de análise científica e, conseguintemente, imparcial: o direito em $\mathrm{si}^{119}$.

Nesta toada, a separação cartesianística entre sujeito e predicado, tão criticada (com razão) por Heidegger, acaba sendo a base para um estudo que visa a analisar o ser-possível sob o viés da lógica modal ${ }^{120}$. Em função mesmo da metodologia fenomenológica adotada nesta, consentir na adoção de um conceito que pudesse estar de alguma maneira fundamentado em uma tal separação seria encaminhar a análise para uma grave contradição metodológica.

Visto que trabalhamos com a ideia de que a verdade é muito mais intuída/revelada/manifestada ( $2^{\mathrm{a}}$ acepção de verdade, cf. nota de rodapé 117 , acima) do que buscada na adequação e correspondência entre coisa e intelecto $\left(1^{\mathrm{a}}\right.$ e $3^{\mathrm{a}}$ acepções de verdade, cf. nota de rodapé 117, acima), não nos parece correto tentar buscar a verdade do ser-jurídico

\footnotetext{
118 Também denominados de "funtores deônticos" pelo Professor Alysson Mascaro (nomenclatura que entendemos mais apropriada por já ressaltar a deonticidade que lhe seria própria). (MASCARO, 2013, p. 150).

${ }^{119}$ De qualquer maneira, urge ressaltarmos um ponto assaz importante para o fim desta Dissertação: jamais foi nossa intenção sugerir, em qualquer parágrafo da análise que estamos tentando desempenhar, que o estudo dos funtores deônticos e a lógica modal em si são aberrações educacionais que mereciam ser extirpadas dos currículos de nossas faculdades. Temos clara convicção, ao contrário, que seria muito conveniente e oportuno inclusive aprofundar o seu estudo, pois o embasamento lógico-dedutivo pode sim ser muito útil à vida de qualquer indivíduo que pretenda exercer uma carreira voltada ao direito, incluindo seu magistério. O que pretendemos é bem menor: na análise da Guilhotina de Hume, em que tencionamos superar o debate Sein/Sollen pela análise da necessidade e possibilidade, estas entendidas em seu viés existencial e não lógicodedutivo.

${ }^{120}$ Ressaltamos que a menção ao excerto do Professor Tércio não tenciona afirmar que o emérito Professor, em suas análises, rende-se e limita-se a tratar o fenômeno jurídico como se minorado a proposições de caráter meramente modal, sem foco no tecido social. Nossa intenção foi apenas de trazer mais elementos sobre o tópico primordial desta que é uma superação do binômio dever-ser/ser no sentido de tentar argumentar que na realidade o binômio ontológico-existencial em jogo é o da necessidade/possibilidade, pensado além do mero formalismo lógico e tecnológico a que pode se limitar uma teoria juspositivista.
} 
em schemata baseados em uma racionalidade meramente lógico-proposicional, que é inerente ao entendimento da possibilidade calculada de acordo com as regras da lógica modal.

Outra consequência possível ao tratar o modo de ser próprio do ser-humano (caracterizado pelo poder-ser) como idêntico ao modo de ser das coisas em geral (embebido daquela "linguagem da necessidade" que já tratamos) diz respeito diretamente à re-condução (sic) forçada do indivíduo ao pretenso-universal, em que pode dissolver-se a ponto de ser de fato esquecido. É de se notar, contudo, que não estamos tratando aqui da universalidade (enquanto vacância) do ser $^{121}$, pois esta abriga a radical possibilidade de singularização histórica em cada Dasein individualmente considerado (ligada assim à ideia mesmo de poder-ser) ${ }^{122}$.

O que pretendemos afirmar com a noção de (re)condução forçada do ser-indivíduo (própria do Dasein) ao universalizado tem a ver precisamente com uma análise estritamente lógico-formal que, ao invés de superar o discurso da necessidade (e por tabela a dicotomia entre ser/dever-ser, a qual entendemos um tanto quanto repetitiva e insípida), acaba por prejudicar a própria análise do indivíduo considerado em sua radical individualidade, no seu reiterado (ainda que limitado) conjunto de decisões quotidianamente pré-deliberadas (muitas vezes sem qualquer auxílio tecnológico-educacional por parte do 'direito' que 'advém' do 'estado'), por força mesmo de seu viés universalizante e metodologicamente necessitante (próprio que é à lógica modal e da matemática em geral, dada a sua função de validar certas proposições através de procedimentos demonstrativos e dedutivos).

\footnotetext{
121 “Quando falamos de um ente (seja ele uma pantera ou uma pirâmide) enquanto ente (e não enquanto pantera ou pirâmide), eis que o to on torna-se aquilo que é comum a todos os entes, e aquilo que é comum a todos os entes é o fato de existirem, o fato de ser. Neste sentido, como dizia Pierce, o ser (Being) é aquele aspecto abstrato que pertence a todos os objetos expressos por termos concretos: ele possui uma extensão ilimitada e uma intenção (ou compreensão) nula. O que vale diz que se refere a tudo mas não tem significado algum. Para ele está claro porque o uso substantivo do particípio presente, normal para os gregos, na linguagem filosófica aos poucos se transfere para o infinitivo, se não em grego, certamente no esse escolástico." (ECO, 1998, p. 18) 122 "A questão sobre o sentido do ser é a mais universal e a mais vazia; entretanto, ela abriga igualmente a possibilidade de sua mais aguda singularização em cada presença. É necessário um fio condutor concreto a fim de se obter o conceito fundamental de 'ser' e de se delinear a conceituação ontológica por ele exigida, bem como suas derivações necessárias. A universalidade do conceito de ser não contradiz a 'especialidade' da investigação, qual seja, a de encaminhar-se, seguindo a interpretação especial de um ente determinado, a presença. É na presença que se há de encontrar o horizonte para a compreensão e possível interpretação do ser. Em si mesma, porém, a presença é 'histórica', de maneira que o esclarecimento ontológico próprio deste ente torna-se sempre e necessariamente uma interpretação 'referida a fatos históricos'." (HEIDEGGER, 2012, p. 39).
} 
Tal como salientado por Umberto Eco:

[...], o recurso ao universal não é uma força de pensamento, mas uma enfermidade do discurso. $\mathrm{O}$ drama é que o homem fala sempre em geral enquanto as coisas são singulares. A linguagem nomeia ofuscando a irresistível evidência do individual existente. (ECO, 1998, p. 28).

De qualquer maneira, há um ponto que merece ser ressaltado para que não paire dúvida sobre o tema: não estamos aqui negando a pujança da linguagem proposicional para a filosofia, muito menos para o estudo do fenômeno jurídico. Na realidade, entendemos que a análise da linguagem acabar por ser indissociável da análise de qualquer estrutura socialmente relacionada a ela.

Tal como afirmado por Gadamer em sua obra Verdade e método ${ }^{123}$, ao analisar a teoria de W. Humbold acerca da linguagem e como ela forma a visão de mundo:

A forma da linguagem e o conteúdo da tradição não podem ser separados na experiência hermenêutica. Se cada língua é uma concepção de mundo, ela não o é primeiramente como representante de um determinado tipo de língua [...], mas através do que se diz e se transmite nessa língua. (GADAMER, 2012, p. 569, grifos no original).

Afinal de contas, continua Gadamer:

\begin{abstract}
A linguagem não é somente um dentre muitos dotes atribuídos ao homem que está no mundo, mas serve de base absoluta para que os homens tenham mundo, nela se representa mundo. Para o homem, o mundo está aí como mundo numa forma que não está para qualquer outro ser vivo que esteja no mundo. Mas esse estar-aí do mundo é constituído pela linguagem. (GADAMER, 2012, p. 571, grifos no original).
\end{abstract}

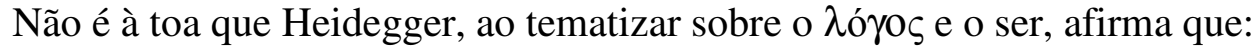

123 GADAMER, Hans-Georg. Verdade e método. - Tradução de Flávio Paulo Meurer. Vol. I. $12^{\mathrm{a}}$ ed. Petrópolis/RJ: Vozes. Bragança Paulista/SP: Editora Universitária São Francisco, 2012. 
O "é" e sua interpretação, quer se exprima linguisticamente ou se indique nas desinências verbais, só entra no contexto dos problemas da analítica existencial se os enunciados e a compreensão de ser forem em si mesmas possibilidades da própria presença [Dasein]. [...]

Disposição e compreender são os existenciais fundamentais que constituem o ser do pre, ou seja, a abertura do ser-no-mundo. O compreender guarda em si a possibilidade de interpretação, isto é, de uma apropriação do que se compreende. [...] O fundamento ontológico-existencial da linguagem é a fala. [...]

Do ponto de vista existencial, a fala é igualmente originária à disposição e ao compreender. A compreensibilidade já está sempre articulada, antes mesmo de qualquer interpretação apropriadora. A fala é a articulação da compreensibilidade. Por isso, a fala se acha à base de toda interpretação e enunciado. (HEIDEGGER, 2012, p. 222-223).

E conclui:

A linguagem é o pronunciamento da fala. [...] A fala é constitutiva da existência da presença [Dasein], uma vez que perfaz a constituição existencial de sua abertura [Erschlossenheit ${ }^{124}$ ]. (HEIDEGGER, 2012, p. 224).

Temos por evidente, contudo, que uma análise da linguagem jurídica, além de usualmente possuir um viés mais técnico-formalista, tem um caráter próprio pelo qual a aplicação de métodos lógico-dedutivos torna-se praticamente impossível (além de metodologicamente incongruente) para sua apreensão: a linguagem jurídica, ao visar ao controle das condutas sociais, não é operacionalizada de modo lógico ou matemático, tratando-se muito mais de movimentos intuitivos e quotidianamente dramáticos do que cálculos proposicionais frios que tencionem alcançar a 'verdadeira' norma.

Dito de outra forma, a operacionalização da linguagem jurídica (a sua utilizabilidade/manuseabilidade - Zuhandenheit, diria Heidegger) acaba por assemelhar-se muito mais a um conjunto de pronunciamentos ritualísticos visando à ordenação social, mais próximos aos procedimentos sacerdotais de um pároco católico ou mesmo de pura magia pagã. Sua força enunciativa, narrativa e consequentemente mimética vem do rito e do mito.

124 “A presença realiza-se em descobrindo. O modo de abertura próprio da presença distingue-se da descoberta na medida em que ela se revela para si mesma, exercendo o papel de revelador. Esse modo de revelação da presença, Ser e tempo o chamou de abertura." (HEIDEGGER, 2012, p. 567-568, nota 25 da tradutora). 
Tal como afirmado por Olivecrona:

\begin{abstract}
O propósito de todas as disposições jurídicas, pronunciamentos judiciais, contratos e outros atos jurídicos, é influir na conduta dos homens e dirigi-la de certas maneiras. A linguagem jurídica tem que ser considerada, em primeiro lugar, como um meio para atingir esse fim. É um instrumento de controle social e de comunicação social. ${ }^{125}$
\end{abstract}

E conclui:

\begin{abstract}
A linguagem jurídica origina-se da linguagem da magia. Esta é a chave de sua explicação histórica. (OLIVECRONA, 2005, p. 96).
\end{abstract}

Mas consideremos por um breve instante, ad argumentandum tantum, que fosse válida a aplicação de elementos lógico-modais para o detalhamento e aprofundamento do fenômeno jurídico, cuja gênesis (Ur-sprung) Karl Olivecrona, com base nos ensinamentos de Hägerström, compreende a partir desta "linguagem da magia". Qual seria o resultado quando tentássemos utilizar apenas a lógica modal para esclarecer o alcance da Guilhotina de Hume?

Neste sentido, acreditamos ser importante verificarmos as conclusões que um estudioso da mais contemporânea lógica modal alcançou quando da análise da Guilhotina de Hume sob um viés exclusivamente lógico-formal, em função até mesmo de sua importância para o desfecho desta Dissertação.

\title{
4.3.1. $\quad$ A lógica modal de Gerhard Schurz
}

O Professor Gerhard Schurz atualmente leciona na Faculdade de Filosofia da Heinrich-Heine Universität Düsseldorf, sendo autor de sete livros e centenas de ensaios que tratam de variados assuntos relacionados à filosofia das ciências, à lógica contemporânea (seja de caráter filosófico, estritamente matemático ou modal), à epistemologia e à metaética.

125 OLIVECRONA, Karl. Linguagem jurídica e realidade. Tradução de Edson Bini. São Paulo: Quartier Latin, 2005, p. 67. 
Ainda quando lecionava na Universidade de Salzburg (em 1997), publicou um livro até hoje considerado como referência para os estudiosos da lógica modal e da meta-ética, de extrema importância para os fins desta Dissertação por tratar exatamente da Guilhotina de Hume sob o viés lógico-proposicional: The is-ought problem: an investigation in philosophical logic ${ }^{126}$.

Baseando-se exatamente na famosa passagem do Treatise de David Hume, em que este mostra-se descrente acerca dos reais motivos pelos quais uma relação de dever-ser (Sollen) poderia ser deduzida/inferida de uma relação meramente fática (Sein), o Professor Gerhard Schurz afirma que:

[...] David Hume put forward a basic argument against the argumentative praxis of ethicists of his time. He stated that from what is (or is not), nothing about what ought to be (or ought not to be) can logically be concluded. This is Hume's isought thesis.

[...] the is-ought-problem has an obvious twin brother in the question whether ethical value statements can be logically inferred from fact statements. To clarify the terminology, we call a statement about what is - [...] - a descriptive statement; a statement about what ought to be a normative statement, a statement about what is valuable a valuative statement, and finally a statement which is either normative or valuative an ethical statement. [...] Although we will focus in the following on the is-ought problem, it is clear that all our results simultaneously apply to Hume's problem in its more general formulation, namely, whether any ethical statements can logically be inferred from descriptive statements. (SCHURZ, 1997, p. 1 et seq.).

Seguindo esta linha de raciocínio, o Professor Gerhard Schurz afirma que sua interpretação acerca da Guilhotina de Hume é direta e simples: ele interpreta o conceito de "dedução"/"inferência" do dever-ser pelo ser, tal como contida na famosa passagem do Treatise, no sentido de "inferência logicamente válida" (SCHURZ, 1997, p. 2), afirmando ser esta a interpretação padrão (standard sense) acerca da Guilhotina de Hume (SCHURZ, 1997, p. 2).

${ }^{126}$ SCHURZ, 1997. 
Contudo, o autor afirma que o problema acerca da correlação entre o ser e o deverser, na realidade, poderia ser entendido de maneira mais ampla, em um sentido expandido (extended sense), vinculado à questão "whether ethical statements may be inferred from descriptive statements in a broader sense of inference which includes also some 'nonlogical' kinds of inference." (SCHURZ, 1997, p. 2).

De qualquer maneira, continua Schurz, "in the is-ought case it is easy to prove that if prescriptive statements are not derivable from descriptive ones, then descriptive statements cannot be derived from prescriptive ones" (SCHURZ, 1997, p. 6), sendo que neste caso, "the upshot will be that if Hume's thesis is true in its standard sense, then there are strong reasons that it is true also in its extended sense." (SCHURZ, 1997, p. 6).

Ainda nesta linha, o Professor Gerhard Schurz conclui que seria patente que "the philosophically extended is-ought thesis entails the standard is-ought thesis, but not vice versa" (SCHURZ, 1997, p. 2), sendo que ele assume, seguindo os ensinamentos de Pidgen, que haveriam três tipos fundamentais de teses envolvendo a autonomia do dever-ser quando comparado/relacionado com o ser, quais sejam: (i) uma autonomia lógica (em que não é logicamente - e, conseguintemente, matematicamente - possível deduzir proposições normativas de proposições factuais); (ii) uma autonomia semântica (pela qual se afirma que as proposições normativas não significam a mesma coisa que as proposições factuais); e (iii) uma autonomia ontológica (pela qual as propriedades éticas seriam sui generis, não sendo possível reduzi-las a propriedades não-éticas) (SCHURZ, 1997, p. 4 et seq.). No que diz respeito a esta terceira acepção, o Professor Gehard Schurz afirma que "the ontological aspect of the problem, in Pidgen's terminology, corresponds to what we have called the isought problem in the extended sense" (SCHURZ, 1997, p. 5).

O autor é peremptório ao declarar a atualidade e premência que a questão acerca da Guilhotina de Hume ainda possui, por tratar de temas caros também aos estudos jurídicos, políticos e sociais:

[...], the question whether or not the is-ought-thesis is true is practically as well as theoretically highly important. The answer one gives to it is decisive for the basic metaethical question how norms and values can, and how they cannot, be justified. This, in turn, is a crossroads for the construction of divergent ethical systems, e.g. 
for the decision between modern naturalistic and nonnaturalistic positions in ethics. Moreover, it plays a crucial role in juridical, political and social sciences. (SCHURZ, 1997, p. 7)

Apesar de as matérias e análise serem extremamente interessantes, não pretendemos aqui detalhar toda a estrutura lógica, linguagem formal ou a axiomatização matemática adotada por Gerhard Schurz quando da sua tentativa de formalmente determinar a autonomia (ou não) das proposições normativas quando relacionadas com proposições de caráter eminentemente descritivo, até mesmo para não fugir do tema proposta para esta Dissertação.

Com efeito, no livro em comento o autor aproveita todos os onze primeiros capítulos (consubstanciados em cerebrinas 277 páginas) exatamente para detalhar todo o arcabouço lógico-matemático por ele utilizado para analisar, no detalhe, as implicações lógico-proposicionais que a Guilhotina de Hume teria no que diz respeito à possibilidade de as proposições normativas (Sollen), de alguma maneira, serem inferidas/deduzidas de proposições descritivas (Sein), o que poderia implicar sua relação autônoma ou não.

Todavia, são as suas conclusões no último capítulo (o de número 12) que entendemos serem de fato relevantes para as discussões que nós mesmo trouxemos ao longo desta.

Em suma, ao tratar dos limites que ele alcançou para justificar cientificamente uma teoria ética (seja ela qual for), Gerhard Schurz traça um paralelo metodológico e comparativo entre a física (ou melhor, entre o mundo das ditas ciências naturais - Naturwissenschaften) e a ética.

Segundo o autor:

It is not the function of ethical norms and values to explain or predict the factual conduct of humans, but to guide their conduct, and to improve it. But what is meant with an 'improvement' of the conduct of the humans [...], is itself something ethical which differs from ethical theory to ethical theory. I do not deny that ethical theories (if rich enough) may imply empirical predictions of the form ' (if someone behaves so and so, he will earn this and this consequences' (for instance, his life will be longer). The correctness of such predictions confirms the theory as an 
empirical theory, but not as an ethical theory. For the latter it is decisive that the correctly predicted empirical consequences of a person's behaviour really count as an improvement of his conduct - but exactly this can't be confirmed by empirical methods. (SCHURZ, 1997, p. 279)

Para o fim de melhor ilustrar o seu ponto, o autor usa um exemplo deveras claro:

\begin{abstract}
For instance, assume two ethical theories $T_{1}$ and $T_{2}$ are given, and $T_{1}$ is better in explaining or predicting the factual behaviour of humans in $20^{\text {th }}$ century western civilization. Does this justify the claim that $T_{1}$ is ethically more correct than $T_{2}$ ? Certainly not. It might be that $\mathrm{T}_{1}$ contains more empirically true laws about the egoistic behaviour of people under certain circumstances than $T_{2}$, and yet $T_{2}$ might be regarded as ethically more adequate than $T_{1}$ because only $T_{2}$ contains the fundamental rules of ethically correct conduct, although humans in western $20^{\text {th }}$ century civilization do not behave according to them. (SCHURZ, 1997, p. 279280)
\end{abstract}

Portanto, a justificação ou validade de qualquer teoria ética, seja ela qual for, não estaria relacionada ao poder ou habilidade que referida teoria possuiria para predizer e explicar o comportamento empiricamente verificado dos indivíduos.

Ainda nesta linha de raciocínio, o autor traça outro paralelo com a física ao afirmar que, sob seu ponto de vista (compartilhado com praticamente a unanimidade dos físicos teóricos na atualidade) não há motivo para duvidar que os elétrons existam e que eles são a de fato a causa dos/para os fenômenos elétricos, razão pela qual a observação e predição de tais fenômenos são capazes de fazer com que se crie uma teoria científica acerca do tema (SCHURZ, 1997, p. 280).

Contudo, o autor questiona um ponto essencial:

Do the theoretical concepts of 'norm' or 'value' likewise refer to entities which really exist in nature independently of us, and which are the hidden causes of the behaviour of people? (SCHURZ, 1997, p. 280).

A resposta dada pelo autor, com a qual concordamos integralmente, é sumária: 
The answer is clearly no, $[\ldots]$. Norms and values serve to guide our conduct, but they are not its cause. (SCHURZ, 1997, p. 280).

Para que não reste qualquer indício de dúvida, o Professor Gerhard Schurz assim condensa sua posição:

\begin{abstract}
Norms and values do not refer to entities which really exist in nature, independently of us. Norms and values are guiding principles which depend on us, on our will and decision which is, at least, to some extent, free. This does not necessarily imply that norms and values have no reference at all - but if they have reference, this reference does not lie 'outside of us', in the external world, but lies somewhere 'in us', in our ethical ideals. Precisely this was Hume's great discovery when he emphasized that 'morality consists not in any relations, that are the objects of science'... 'It lies in yourself, not in the object' [...].
\end{abstract}

Since norms and values are not the unobservable causes of empirical data like the behaviour of people, the scientific confirmation method is inadequate for ethics. (SCHURZ, 1997, p. 281).

E finaliza o livro com a seguinte conclusão:

The conclusion remains still valid that the situation in ethics is basically different from the situation in science. Nature cannot tell us which ethical concept is the right one: we have to decide. Intersubjective agreement in ethics is not given by a common nature which exists independently from us. [...] It is basically the result of a common culture which enables mutual understanding and a common life practice. (SCHURZ, 1997, p. 285).

Em outras palavras: mesmo esforçando-se para provar, de maneira lógico-formal e proposicional, que poderia haver uma maneira de justificar cientificamente as teorias éticonormativas, no sentido de conceder autonomia (lógica, semântica e/ou ontológica) às formulações proposicionais de caráter prescritivo (normative statements), quando relacionadas com proposições de caráter descritivo, o Professor Gerhard Schurz concluiu que seria impossível (pela lógica modal pura e simplesmente) determinar o caráter autônomo e intersubjetivo de qualquer teoria normativa, que acabaria sempre por depender de decisões humanas para ser implementada/imposta - ou aceita. 
Deste modo, seria impossível determinar de antemão até mesmo se as normas seriam efetivamente inferidas a partir de proposições meramente descritivas pois as normas “do not refer to entities which really exist in nature, independently of us. Norms and values are guiding principles which depend on us, [...]". (SCHURZ, 1997, p. 281).

A percepção de adequação entre conduta e norma, ou mesmo o seu efetivo "conteúdo", dependeria de uma atitude decisional-comportamental do ser humano, a quem caberia de fato estabelecer uma separação entre aquilo que poderia ser considerado como normativamente adequado (o ético, o jurídico, o religioso) e aquela conduta considerada contrária ao normativo (o não-ético, o antijurídico, a apostasia).

Mencionada percepção, diferentemente do quanto usualmente se destaca, não advém de qualquer processo de subsunção/imputação lógico-matemático em que o assim chamado "operador" do direito consegue, imparcial e cirurgicamente, recortar o continuиm espaço-temporal para determinar se os fatos, atos e omissões que ressaltam deste recorte devem ou não ser considerados como juridicamente adequados (e obviamente, as consequências que daí decorrem).

Dito de outra maneira: a adequação de determinada conduta emana de uma decisão tomada dentre uma quase infinidade de possibilidades que, por seu turno, reciprocamente acabam por demandar do ser humano, ininterruptamente, uma tomada de decisão, entre uma superabundância delas, enquanto troca para conseguirmos viver em sociedade.

Mas se esta quase infinidade de possibilidades não consegue ser adequadamente apreendida como potencialidade/virtualidade (uma mera espera pela atualização do sernecessário) ou como possibilidade lógico-proposicional (em si, insípida e quiçá politicamente mais arriscada), como apreendê-la?

Sugerimos, para tanto, que passemos a tratar especificamente do ser-jurídico sob o ponto de vista do ser-possível existencial. 


\section{CAPÍTULO 5. A POSSIBILIDADE EXISTENCIAL}

\subsection{Confronto entre o ser-possível e a realidade (ser-real)}

Ao longo desta Dissertação tencionamos primeiramente detalhar como a modalidade da necessidade (o ser-necessário) permeia sobremaneira toda a percepção narrativa e mitológica que o ser-humano ainda tem de si, da existência e da relação recíproca que daí surge, mormente ao tratarmos do que se apreende como ser-jurídico.

Do ponto de vista jusfilosófico, aquela "linguagem da necessidade" que Abbagnano mencionou é claramente destaque no positivismo (filosófico e jurídico). Nesta linha, concentramos boa parte de nossa análise em como o ser-jurídico também se encontra arraigado e preso àquela "linguagem da necessidade" que, sob nossa perspectiva, pode empobrecer o debate na jusfilosofia por, dentre outras questões já tratadas, reforçar uma prédestinação do humano, em que se perde a própria possibilidade mesma de uma superação (Verwindung) daquilo que nos é desde sempre simplesmente já dado (Vorhandenheit) ou posto à disposição (Zuhandenheit). Afinal, se tudo é predestinado (ou estatalmente determinado), aparentemente precisaríamos apenas achar a 'verdade', o 'absoluto', a 'Grundnorm', a "interpretação autêntica”, a vontade última do soberano, para que possamos encontrar o incorruptível caminho sobre o qual deveríamos trilhar nossas decisões (o serúnico próprio dos eleatas).

Posteriormente começamos a trazer elementos outros envolvendo o debate em torno da modalidade da possibilidade (o ser-possível) de forma a argumentarmos no sentido de que o ser-possível é de fato a modalidade existenciária que fundamenta o ser-jurídico (visto ser a modalidade que fundamenta a própria existência humana enquanto tal - Dasein), em sua verdade social mais própria.

Afinal de contas, como salientado por Heidegger no $\$ 7$ do Ser e tempo, momento em que ele tenta tornar menos nítida a linha de demarcação entre ontologia e fenomenologia (em que esta passa a ser tratada como uma ontologia não dogmatizante e estratificada, como ocorreu com a ontologia escolástica, por exemplo): 
Ontologia e fenomenologia não são duas disciplinas distintas da filosofia ao lado de outras. Ambas caracterizam a própria filosofia em seu objeto e em seu modo de tratar. A filosofia é uma ontologia fenomenológica e universal que parte da hermenêutica da presença [Dasein], a qual, enquanto analítica da existência, amarra o fio de todo questionamento filosófico no lugar de onde ele brota e para onde retorna.

[...] As explicitações do conceito preliminar de fenomenologia demonstraram que o que ela possui de essencial não é ser uma 'corrente' filosófica real. $\underline{\text { Mais elevada }}$ do que a realidade está a possibilidade. A compreensão da fenomenologia depende unicamente de se apreendê-la como possibilidade. (HEIDEGGER, 2012, p. 78).

Deixando de lado o ser-possível sob o aspecto lógico-modal (insípido e muitas vezes descolado de referência fática), vimos que a identificação do ser-possível com aquilo que pode vir a se tornar real/atual (o ser-potência de Aristóteles) peca por confundir a modalidade da possibilidade com outra de fato de outro gênero: a modalidade da necessidade (ser-necessário).

No final das contas a potencialidade não consegue tornar-se independente do sernecessário à medida que "la potenzialità è una determinazione della necessità e serve anzi esplicitamente a mantenere e a garantire la necessità dell'essere nel suo divenire" (ABBAGNANO, 1956, p. 71, grifos nossos).

Ainda seguindo os ensinamentos de Abbagnano:

Concepito come passaggio dalla potenza all'atto, il divenire rivendica per sé la stessa necessità dell'essere attuale perché è giá, nel suo stadio iniziarle (come potenza) ciò che l'essere é nel sua stadio finale. (ABBAGNANO, 1956, p. 71).

Com efeito, refutamos que o ser-possível seja destinado a realizar-se de maneira certa e infalível (ABBAGNANO, 1956, p. 75), caso contrário estaríamos aceitando a ideia da potencialidade aristotélica (aquilo que pode ser mas que, infalivelmente e de um jeito ou de outro, deverá ser, algum dia).

Arrastando esta ideia para a jusfilosofia, e se aceitássemos que o ser-normativo (jurídico, -ético, -religioso, etc.) confunde-se com o ser-potência, todo ser-normativo, de 
alguma forma e em algum momento-movimento do continuum espaço-temporal, necessariamente terá de ser, o que nos parece ser logicamente contraditório e ontologicamente insubsistente.

Entretanto, de qualquer maneira não podemos olvidar que a realização/atualização do ser-possível (em suma: aquele momento-movimento em que o ser-possível torna-se realidade) não pode ser entendida como a negação do ser-possível como tal.

\section{Muito pelo contrário!}

$\mathrm{Na}$ realização/atualização, utilizando-se mais uma vez do pensamento de Abbagnano, é que o ser-possível acaba por fundamentar sua própria possibilidade existencial e filosófica (ou transcendental, nos dizeres do professor italiano):

Realizzandosi, il possibile si fonda nella sua stessa possibilità, si rafforza in essa e per essa come un possibile. Se chiamiamo possibilità transcendentale la possibilità di un possibile, la realizzazzione del possibile è il suo rapportarsi con la possibilità transcendentale. [...]

[...] alla possibilità non si contrappone l'attualità come la pienezza e la concretezza dell'essere di fronte ad un essere puramente ideale o comunque diminuito.

$\underline{\text { L'attualità si contrappone e si lega alla potenzialità, e l'una e l'altra sono }}$ determinazioni del necessario. Se la filosofia deve mantenersi [...] nella categoria del possibile, il rapporto che essa deve riconoscere non è quello potenzialitàattualità ma quello possibilità-possibilità transcendentale. [...] $\underline{\text { L'essere di cui la }}$ filosofia può parlare è, in ogni caso e soltanto, l'essere possibile. (ABBAGNANO, 1956, p. 76-77, grifos nossos).

Nesta toada, poderíamos tentar compreender o fenômeno jurídico para apreendê-lo sob outro viés, aquele pelo qual a juridicidade passaria a ser entendida como uma conduta pré-deliberada e intuitivamente decisional (e não idealizada e dependente de um ensino esotérico e ritualístico, como ocorreria se creditássemos o dever-ser estatalizante como fundamento para tanto), estando inclusive muito além do mero normativismo juspositivista (calcado como este se encontra em um conceito vazio e idealista, a norma jurídica). O serjurídico, em seu âmago, estaria assim muito mais próximo do ser-possível, o mundo das possibilidades. 
Contudo, temos que estar sempre atentos à admoestação feita por Karl Jaspers ao tratar da força filosófica que nos impele buscar além do conjunto das meras possibilidades (até mesmo para evitarmos recair na armadilha do matematismo formalista a que se resume uma análise modal do ser-possível): "we do not want possibililities; we want reality."

Mas o que seria a realidade, portanto?

A realidade (o ser-real) em conjunto com a necessidade (o ser-necessário) e a possibilidade (o ser-possível) formam os pilares daquilo que usualmente sempre foi tratado na filosofia como o debate acerca das modalidades, tal como mencionamos en passant (ao tratarmos do estado inicialmente vivenciado pelos infantes humanos de não-diferenciação entre realidade, necessidade e possibilidade, conforme afirmado por Jean Piaget).

A título de contextualização, o significado mais próprio e tradicionalmente atribuído à realidade tem a ver com "o modo de ser das coisas existentes fora da mente humana ou independentemente dela" (ABBAGNANO, 2007, p. 976), de forma que a problemática diretamente suscitada a partir da noção de realidade é exatamente a "da existência das coisas ou do 'mundo exterior'” (ABBAGNANO, 2007, p. 976), e como este mundo exterior relacionar-se-ia com o mundo interior, como exemplifica a teoria do eu cartesiano $^{128}$.

Seguindo esta linha de raciocínio, o oposto da realidade seria a idealidade (ou o idealismo que, em nossa concepção, é a base de fundamentação teorética para o conceito de dever-ser em sua forma tradicional, amarrada que se encontra aos grilhões do modalismo e da lógica meramente proposicional), sendo que referido idealismo:

[...] indica o modo de ser daquilo que está na mente e não pode ou ainda não foi incorporado ou atualizado nas coisas. A referência a coisas também está evidente em expressões como 'definição real', para indicar a definição da coisa, e não do

127 JASPERS, Karl. The philosophy of existence. Tradução de Richard F. Grabay. - $7^{a}$ ed. Philadelphia: University of Pennsylvania Press, 1995, p. 61 (grifos nossos).

${ }^{128}$ Com efeito, o eu "passou a ser objeto de investigação filosófica a partir do momento em que a referência do homem a si mesmo, em termos de reflexão ou consciência, foi assumida como definição do próprio homem. Foi o que aconteceu com Descartes, que foi o primeiro a formular em termos explícitos o problema do eu." (ABBAGNANO, 2007, p. 453) 
nome, e 'direitos reais', para indicar os direitos pertinentes às coisas, e não às pessoas. (ABBAGNANO, 2007, p. 976).

Em todo caso, mais recentemente, e a partir principalmente das questões e suspeitas trazidas à baila pelo existencialismo (ou, mais especificamente, pela fenomenologia existencial), o problema em torno da realidade "praticamente deixou de ser problema da 'existência' das coisas para tornar-se cada vez mais problema do modo de ser específico das coisas" (ABBAGNANO, 2007, p. 977).

Para aclarar um pouco melhor esta questão, precisamos recorrer aos ensinamentos do próprio Martin Heidegger, cuja obra, em muitos aspectos extremamente dependente dos textos e conceitos aristotélicos, é de substancial valia para se compreender mais a fundo a ideia mesma de possibilidade sob o viés existencial, enquanto fundamento do mundo éticojurídico.

Apenas para fins de completude, ressaltamos que a problemática em torno da apropriação feita por Heidegger da obra aristotélica já foi suficientemente tratada pela doutrina filosófica mais recente. Podemos encontrar convincentes amostras desta aproximação nas obras de dois contemporâneos filósofos italianos, Enrico Berti e Franco Volpi (o último já citado algumas vezes ao longo desta Dissertação).

De fato, Berti afirma que "a transformação no modo de interpretar Aristóteles, [...], foi determinada em Heidegger pela chegada de Husserl a Freiburg." ${ }^{29}$. E Heidegger teria ainda escrito em uma carta enviada em 1923 a Courtine que "na minha indagação me foi companheiro de estrada Lutero e modelo Aristóteles, que era odiado por aquele." (BERTI, 1997 , p. 81).

Ainda nesta toada, Berti afirma, ao prefaciar a obra de Volpi, que este mostra:

[...] come in Sein und Zeit Heidegger si sia appropriato, in un modo che egli definisce addiritura 'vorace', delle categorie principali della filosofia pratica di Aristotele, svuotandole del loro significato pratico e riempiendole di un nuovo

${ }^{129}$ BERTI, Enrico. Aristóteles no século XX. Tradução de Dion Davi Macedo. - São Paulo: Edições Loyola, 1997, p. 70. 
significato ontologico, per farne le strutture portanti della sua fenomenologia della condizione umana. (VOLPI, 2010, p. X do prefácio, grifos no original).

A constante sombra de Aristóteles sobre a obra de Heidegger pode ainda ser observada em um texto pouco conhecido (até mesmo pelo fato de ele ter permanecido inédito por quase setenta anos, conforme testemunho de Enrico Berti, vindo a ser publicado apenas em $1989^{130}$ ), escrito pelo próprio Heidegger no outono de 1922, usualmente denominado de relatório Natorp (Natorp Bericht).

Com efeito, trata-se de um texto que Heidegger endereçou a Paul Gerhard Natorp, um dos maiores pensadores neokantianos, co-fundador da Escola de Marburg (ao lado de Cohen e Cassirer), com a finalidade de explicitar sua interpretação acerca da obra de Aristóteles (e que impressionou Natorp a ponto de este vir a sugerir sua convocação para a cátedra de Marburg, na qualidade de sucessor de Natorp, o que de fato ocorreu) (BERTI, 1997, p. 75).

Em uma premissa intitulada "Programa da situação hermenêutica", Heidegger foi incisivo ao afirmar que a interpretação [filosófica, pressupomos] nada mais é do que uma apropriação do passado, e mais especificamente Aristóteles, por meio da compreensão, o que seria feito através de uma desconstrução, uma desestruturação, uma desmontagem (BERTI, 1997, p. 76).

Feitas estas considerações, salientamos que partilhamos com a ideia de Volpi no sentido de que:

[...] nel confronto heideggeriano con Aristotele e col pensiero greco si può constatare in generale una fondamentale ambivalenza che si manifesta negli ossimori metodologici cui Heidegger è propenso - distruzione come appropriazione radicale, attraversamento come superamento e oltrepassamento, 'Überwindung' come 'Verwindung' - e che esige di essere chiarita. Per un verso, infatti, Heidegger sottolinea che i Greci, e in particolare Aristotele, rappresentano

\footnotetext{
${ }^{130}$ Cf. BERTI, 1997, p. 75. O professor italiano explica ainda que do referido texto "foi publicada não a cópia enviada a Natorp, que acabou nas mãos de Gadamer e foi destruída no bombardeio de Leipzig, mas outra cópia, que Heidegger enviara a Georg Misch para ser eventualmente chamado a Göttingen (para onde, ao contrário, foi chamado Moritz Geiger), reencontrada entre as cartas de um aluno de Misch, Joseph König: [...].” (BERTI, 1997, p. 75-76, nota 28 do próprio autor).
} 
la dimensione radicale dell'Occidente, cosicché una comprensione dell'epoca presente che non tenga conto di questa radice risulta infondata e contradittoria. D'altro canto, però, questo ritorno ai Greci à da lui attuato nella forma di una radicale messa in questione del pensiero occidentale nella quale viene coinvolta la stessa filosofia greca. (VOLPI, 2010, p. 146, grifos no original).

E ainda Volpi:

l'appropriazione radicale dell'ontologia e della filosofia pratica aristoteliche permette a Heidegger di risolvere i problemi in cui si arenano le moderne filosofie del soggetto, e segnatamente la fenomenologia husserliana, ma approda poi alla fine a scoprire, e dover mettere dunque in questione, i presupposti sui quali poggia la stessa comprensione aristotelica dell'essere [...]. L'approfonditamento ontologico che Heidegger mette in atto, prima come 'distruzione' e poi come 'passo indietro' e oltrepassamento, non conosce arresto e si compie con una consumazione pressoché totale dello spazio tradizionale della filosofia e con l'approdo a un pensiero che non vuole più esse filosofia, ma radicale messa in questione della filosofia, e che prende forma nei modi di un 'pensiero memorativo' o 'pensiero poetante'.” (VOLPI, 2010, p. 146).

E como poderíamos praticar esta "distruzione come appropriazione radicale" quando estamos tratando do fenômeno jurídico? A realidade (e a consequente realidade do ser-jurídico, pensado ontológica e fenomenologicamente) seria uma entidade estática, baseada em regras e provisões normativas imutáveis, ou seríamos capazes de conduzir uma superação, uma “"Überwindung' come 'Verwindung””, como sugerido por Volpi no excerto acima?

Em suma: se o fenômeno jurídico não é um amontoado de preceitos (ditos) normativos (e quiçá religiosamente estáticos) que somente os iniciados (as tecnossacerdotisas e os tecnossacerdotes do direito) são capazes de apreender, como apreendê-lo o seu modo de ser ontologicamente originário, em sua realidade mais própria?

\subsection{1. $\quad$ Aristóteles e Heidegger (confluências)}

Para prosseguirmos, todavia, entendemos ser recomendável frearmos o texto principal para trazermos a lume algumas relevantíssimas notas ou chaves de 
tradução/interpretação em vista (i) da edição de Ser e tempo que utilizamos durante nossa pesquisa (cuja versão para a língua portuguesa foi feita pela Professora Marcia Sá Cavalcante Schuback) e (ii) da problemática em torno da apropriação feita por Heidegger da obra aristotélica $^{131}$.

Em primeiro lugar, aclaremos um dos termos mais utilizados por Heidegger em sua obra: Dasein. Tal como afirmado pela Professora Marcia Sá Cavalcante Schuback, o termo Dasein originariamente:

[...] não é sinônimo de existência e nem de homem. A palavra Dasein passa a ser usada na língua filosófica alemã no século XVIII como tradução da palavra latina praesentia. Logo em seguida passa também a traduzir o termo existentia, sendo por isso comumente usada no alemão moderno na acepção de existência. Em Ser e tempo, traduz-se, em geral, para as línguas neolatinas pela expressão 'ser-aí', être-là, esser-ci, etc. (HEIDEGGER, 2012, p. 561, nota 1 da tradutora, grifos no original).

Ao longo desta Dissertação, e em função mesmo dos seus fins, tratamos como correlatos (embora não como homônimos) os termos Dasein, ser-humano, presença e existência. Contudo, a Professora Marcia Sá Cavalcante Schuback entendeu por bem traduzilo unicamente por presença, pelos motivos que ora transcrevemos por sua relevância filosófica:

\footnotetext{
1) para que não fique [o Dasein] aprisionado às implicações do binômio metafísico essência-existência; 2) para superar o imobilismo de uma localização estática que o 'ser-aî' ou o 'estar-aí' sugerem [...]; 3) para evitar um desvio de interpretação que o 'ex' de 'existência' suscitaria caso permanecesse no sentido metafísico de exteriorização, atualização, realização, objetivação e operacionalização de uma essência [...]; 4) presença não é sinônimo nem de homem, nem de ser humano,
}

\footnotetext{
${ }^{131}$ Muito embora já tenhamos utilizado algumas vezes palavras e conceitos escritos em línguas alemã e grega no decorrer da Dissertação, as notas de tradução/interpretação que pretendemos ora salientar dizem respeito especificamente a um detalhamento dos termos da fenomenologia heideggeriana, da obra aristotélica e da tradução de Ser e tempo que utilizamos em nossa pesquisa (e devem assim ser consideradas todas as vezes em que foram por acaso mencionadas anteriormente ao longo do texto), em sua intrínseca correlação, para fins inclusive de amarração teórica com os Capítulos anteriores. Entendemos por bem somente agora trazer tais chaves de interpretação e tradução para aclarar pontos da fenomenologia heideggeriana (e seu contato com a obra aristotélica) que serão de fato melhor trabalhados neste Capítulo, caso contrário os temas ficariam jogados ao léu nos itens anteriores (o que, receamos, poderia ofuscar o alcance dos temas anteriormente tratados).
} 
nem de humanidade, embora conserve uma relação estrutural. (HEIDEGGER, 2012, p. 561, nota 1 da tradutora) $)^{132}$

A título de reforço, podemos citar os próprios ensinamentos que Heidegger traz quando trata da presença (Dasein), na tentativa de melhor aclarar o conceito e sua relação com os temas desta:

Como atitude do homem, as ciências possuem o modo de ser desse ente (homem). Apreendemos terminologicamente esse ente como presença. A pesquisa científica não é o único modo de ser possível desse ente [a presença] e nem sequer o mais próximo. $[$...]

A presença não é apenas um ente que ocorre entre outros entes. Ao contrário, ela se distingue onticamente pelo privilégio de, em seu ser, isto é, sendo, estar em jogo seu próprio ser. [...] Isso significa, explicitamente e de alguma maneira, que a presença se compreende em seu ser, isto é, sendo. É próprio deste ente que seu ser se lhe abra e manifeste com e por meio de seu próprio ser, isto é sendo. (HEIDEGGER, 2012, p. 47-48, grifos nossos). ${ }^{133}$

Mas se a presença somente é enquanto sendo, e considerando que não é possível conceber uma presença totalmente isolada, temos de apreender o Dasein sempre de forma a entendê-lo como um ser-no-mundo, que passa assim constituir fundamentalmente o próprio Dasein.

Nas palavras de Heidegger:

O ser-em, [...], significa uma constituição de ser da presença e é um existencial $^{134}$. [...]

Como existencial, o 'ser-junto’ ao mundo nunca indica um simplesmente dar-se em conjunto de coisas que ocorrem. Não há nenhuma espécie de ‘justaposição’ de um ente chamado 'presença' a um outro ente chamado 'mundo'. [...]

\footnotetext{
${ }^{132}$ Certamente não seria possível traduzir Dasein literalmente por existência, pois Heidegger conserva um termo próprio para esta (Existenz). Com efeito, "Ser e tempo reservou 'existência' para designar toda a riqueza das relações recíprocas entre presença e ser, entre presença e todas as entificações, através de uma entificação privilegiada, o homem. Nesta acepção, só o homem existe. A pedra 'é', mas não existe. O carro 'é', mas não existe. Deus “é', mas não existe.” (HEIDEGGER, 2012, p. 563, nota 2 da tradutora).

133 A repetição do gerúndio do verbo "ser" neste excerto não nos parece ser meramente pleonástica, mas constitutiva do estudo a que Heidegger se propõe, qual seja, uma ontologia fenomenológica, desagrilhoando a metafísica das amarras escolásticas a que foi aferrada durante os séculos anteriores.

134 "Existencial remete às estruturas que compõem o ser do homem a partir da existência em seus desdobramentos advindos da presença." (HEIDEGGER, 2012, p. 563, nota 5 da tradutora).
} 
[...], o ser-no-mundo não é uma 'propriedade' que a presença às vezes apresenta e outras não, como se pudesse ser igualmente com ela ou sem ela. [...] A presença nunca é [...] livre de ser-em que, algumas vezes, tem gana de assumir uma 'relação' com o mundo. Esse assumir relações com o mundo só é possível porque a presença, sendo-no-mundo, é como é. (HEIDEGGER, 2012, p. 100-101).

Para arrematar, salutares os ensinamentos da Professora Jeannette Maman sobre o tema:

\begin{abstract}
Heidegger não se satisfaz com a reflexão conceitual, como se as ideias tivessem vida própria e nossa existência individual e social fosse secundária. O Dasein (o ente humano existente) mostra que o homem não é um animal racional ou um ente divino [...]; o homem é um ente que está na existência (que é a mesma coisa que dizer: está desde sempre), percebe que sua existência já estava aí antes de ele começar a pensar. ${ }^{135}$ (MAMAN, 2003, p. 53, grifos no original).
\end{abstract}

Retomando, há outro termo que também merece nossa atenção ao analisarmos a obra de Heidegger: o substantivo Vorhandenheit, o qual "é formado do substantivo Hand (= mão) e da preposição vor (diante de, no sentido espacial e antes de, no sentido temporal)" (HEIDEGGER, 2012, p. 563, nota 8 da tradutora, grifos no original). Em tradução livre, poderíamos dizer que é aquilo que está sempre diante de nós, já anteriormente dado/transmitido/pré-compreendido/projetado.

E Heidegger, já no primeiro capítulo de Ser e tempo, deixa bem claro que o modo de ser de um Vorhandenheit (traduzido pela Professora Marcia Sá Cavalcante Schuback como, ser simplesmente dado) não com-partilha (sic) do modo de ser próprio do Dasein, do ser-humano, daquele que é somente enquanto sendo:

O ente que temos a tarefa de analisar somos nós mesmos. [...]

A 'essência' deste ente está em ter de ser [sendo]. A quididade (essentia) deste ente, na medida em que dela se possa falar, há de ser concebida a partir de seu ser (existência). Neste propósito, é tarefa ontológica mostrar que, se escolhemos a palavra existência para designar o ser deste ente, esta não tem e nem pode ter o significado ontológico do termo tradicional existentia. Para a ontologia

${ }^{135}$ MAMAN, Jeannette Antonios. Fenomenologia existencial do direito: crítica do pensamento jurídico brasileiro. $2^{\text {a }}$ ed. São Paulo: Quartier Latin. 2003. 
tradicional, existentia designa o mesmo que ser simplesmente dado, modo de ser que não pertence à essência do ente dotado do caráter de presença. Evita-se uma confusão usando a expressão interpretativa ser simplesmente dado para designar existentia e reservando-se existência como determinação ontológica exclusiva da presença. (HEIDEGGER, 2012, p. 85, grifos no original).

E conclui:

A 'essência' da presença está em sua existência. As características que se podem extrair deste ente não são, portanto, 'propriedades' simplesmente dadas de um ente simplesmente dado que possui esta ou aquela configuração. As características constitutivas da presença são sempre modos possíveis de ser e somente isso. (HEIDEGGER, 2012, p. 85, grifos nossos).

Assim, dentre os seres/entes intramundanos, Heidegger observa que existiriam aqueles que são simplesmente dados (Vorhandenheit) e aqueles que vêm ao encontro da presença (Dasein), para que esta deles se ocupe com cuidado/cura $\left(\right.$ Besorgen $\left.^{136}\right)$, visto que “em sua essência, o ser-no-mundo é cura [...]. A cura caracteriza não somente a existencialidade, separada da facticidade e decadência, como também abrange a unidade dessas determinações ontológicas.” (HEIDEGGER, 2012, p. 260).

E Heidegger arremata declarando expressamente que seria no fenômeno do querer que "transparece a totalidade subjacente da cura." (HEIDEGGER, 2012, p. 262).

Quanto àqueles seres que viriam ao nosso encontro, que já desde sempre nos se presentificam, a lição de Heidegger nos parece suficientemente clara:

\footnotetext{
Os gregos possuíam um termo adequado para dizer as 'coisas': $\pi \rho \alpha ́ \gamma \mu \alpha \tau \alpha$, isto é, aquilo com que se lida $(\pi \rho \tilde{\alpha} \xi 1 \varsigma)$ na ocupação. Eles, no entanto, deixaram de esclarecer ontologicamente, justamente o caráter 'pragmático' dos $\pi \rho \alpha ́ \gamma \mu \alpha \tau \alpha$, determinando-os 'imediatamente' como 'meras coisas'. Designamos o ente que vem ao encontro na ocupação com o termo instrumento. [...]

Rigorosamente, um instrumento nunca 'é'. O instrumento só pode ser o que é num todo instrumental que sempre pertence a seu ser. Em sua essência, todo
}

136 "Ser e tempo decidiu-se pelo étimo Sorge = lat. cura [...] para acompanhar o movimento e as relações da presença. [...] A tradução decidiu utilizar o radical latino cura par Sorge, ocupação para Besorgen e preocupação para Fürsorge." (HEIDEGGER, 2012, p. 563, nota 12 da tradutora, grifos no original). 
instrumento é 'algo para [...]”. Os diversos modos de 'ser para' (Um-zu) como serventia, contribuição, aplicabilidade, manuseio constituem uma totalidade instrumental. [...]

Ao se lidar com o instrumento no uso, a ocupação se subordina ao ser para (Um$z u$ ) constitutivo do respectivo instrumento. [...] Denominamos de manualidade o modo de ser do instrumento em que ele se revela por si mesmo. O instrumento está disponível para o manuseio, em sentido amplo, unicamente porque todo instrumento possui esse 'ser-em-si', não sendo o que simplesmente ocorre. (HEIDEGGER, 2012, p. 116, grifos no original).

No que toca ainda a esta manualidade/manuseabilidade (Zuhandenheit - aquilo que é enquanto o temos à mão para algo), a Professora Marcia Sá Cavalcante Schuback é incisiva ao se posicionar sobre a centralidade que o manusear possui na obra heideggeriana:

\footnotetext{
No exercício histórico da presença, a mão ocupa um lugar central de concretização e desdobramento. O limite para frente desse exercício é imposto pelos seres simplesmente dados (Vor-handenheit). A doação dos desempenhos e das possibilidades de desempenho proporciona os seres à mão, os seres constituídos pela manualidade (Zu-handen). (HEIDEGGER, 2012, p. 566, nota 18 da tradutora, grifos no original).
}

Novamente não foi por mero diletantismo que fizemos ressaltar os elementos mais característicos que o Dasein, o Vorhandenheit e o Zuhandenheit possuem dentro da obra de Heidegger. Com efeito, ao confrontarmos tais elementos com a ontologia aristotélica é possível notarmos vários pontos de contato hermenêutico, pelos quais o Dasein heideggeriano seria o correlato da $\pi \rho \alpha ́ \xi \xi \varsigma$ aristotélica, o Vorhandenheit seria o correlato da

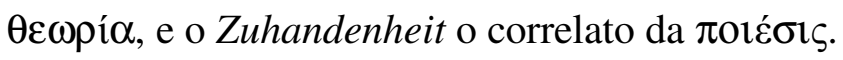

Na realidade, autores como Volpi tendem a considerar que Heidegger apropriou-se originariamente (radicalmente) de vários elementos da obra aristotélica, que passaram a incorporar sua própria obra, como já salientado ao longo desta Dissertação.

Neste sentido, ao analisar Aristóteles, Heidegger considerava que:

[...], la theoria e la ragione sono soltanto uno dei molti modi possibili di quell'attegiamento scoprente mediante il quale l'uomo ha accesso alle cose e le 
coglie. Accanto ala theoria, e forse prima della theoria, vi sono ad esempio l'attegiamento pratico-morale (praxis) e l'attegiamento pratico-tecnico (poiesis), che rappresentano anch'essi um modo in cui l'esserci sta in rapporto com l'ente e lo scopre. (VOLPI, 2010, p. 58).

\section{E Franco Volpi condensa referida opinião ao afirmar que:}

[...], prescindendo da tutti gli altri aspetti dell'analitica dell'esserci in Essere e tempo, si può dire che da un punto di vista ontologico essa introduca la distinzione di tre modi d'essere fondamentali, e precisamente l'esserci (Dasein), l'utilizzabilità (Zuhandenheit) e la semplice presenza (Vorhandenheit). Como'é noto, l'esserci - connotato come un essere-nel-mondo aperto nei confronti dell'ente e caratterizato in questa sua apertura (Esrchlossenheit) da determinate sttruture dette 'esistenziali' - è il modo d'essere proprio della vita umana. In quanto tale l'esserci è radicalmente distinto dal modo d'essere dell'ente diverso da esso (nichtdaseinsmäßiges Seiendes), cioè dal modo d'essere delle 'cose'. Queste, a seconda della disposizione nella quale l'esserci vi si rapporta, possono essere incontrate o nel mondo d'essere dell'utilizzabilità (quando vengono adoperate como strumenti o arnesi in un contesto operativo) o in quello della semplice presenza (quando esse sono oggetto di mera osservazione). (VOLPI, 2010, p. 59, grifos no original).

Em outras palavras: os três modos de ser fundamentais seriam a presença

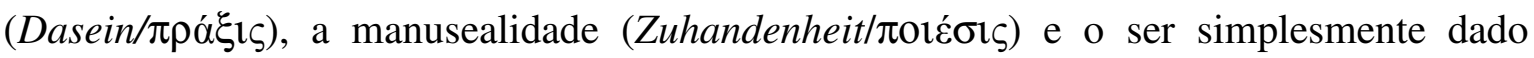

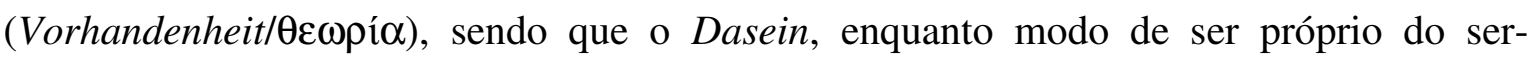
humano, e como já mencionado acima, é apresentado por Heidegger como um ser-em e um ser-com ${ }^{137}$ nos quotidianos e ininterruptos confrontos com os demais entes, e cuja abertura (Esrchlossenheit) é o que determinará o modo de ser próprio do ser-humano.

Algumas observações adicionais se fazem necessárias para tornar este ponto, de essencial importância, o mais claro possível.

\footnotetext{
137 “O ser é sua dinâmica de exercício e por isso sempre difusivo de si mesmo. Em consequência, todas as realizações em modos de ser trazer inscritas na sua constituição essa dinâmica difusiva do ser. A presença é o lugar em que a aparece esta imbricação. Por isso, todas as suas concretizações na existência exercem uma ação expressa pela preposição com (mit). Assim, nunca se dá um ser ou modo de ser isolado. Todo ser é sempre sercom; mesmo na solidão e isolamento, a presença é sempre copresença (Mitdasein), o mundo é sempre mundo compartilhado (Mitwelt), o viver é sempre convivência (Miteinandersein).” (HEIDEGGER, 2012, p. 570-571, nota 34 da tradutora).
} 
Não é demais relembrarmos que em Aristóteles a $\theta \varepsilon \omega \rho i ́ \alpha$ é a atividade mais nobre por excelência ${ }^{138}$. Entretanto, tal ocorria, entre outras questões (inclusive de caráter político), pela predileção aristotélica pela observação, para o fim de buscar compreender o mundo como objeto de estudo.

Já para Heidegger, ao contrário, a ordem de valoração entre os três modos de ser não é orientada ao objeto, mas é trazida de uma reflexão muito peculiar acerca do modo de ser próprio da vida humana, o Dasein, que passa assim a ter um primado ôntico e ontológico (VOLPI, 2010, p. 60).

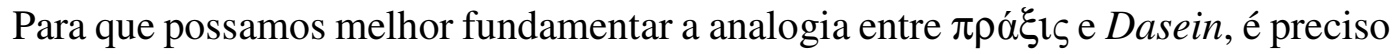
mostrar "che la caratterizzazione heideggeriana della vita umana in termini di esserci mira a cogliere la determinazione ontologica fondamentale sulla quale poggiano tutte le altre determinazione dell'esserci, e che tale determinazione fondamentale dell'esserci viene colta a partire da una comprensione del suo modo d'essere come um modo d'essere pratico (-morale)." (VOLPI, 2010, p. 60, grifos nossos).

Ora, como já transcrevemos acima, a essência do Dasein advém exatamente do fato que "este ente está em ter de ser [sendo]. A quididade (essentia) deste ente, na medida em que dela se possa falar, há de ser concebida a partir de seu ser (existência)" (HEIDEGGER, 2012, p. 85). Esta relação, no final das contas:

\footnotetext{
[...] non si tratta cioè di un attegiamento teoretico, constatativo e veritativo, che si rivolge all'esserci per coglierne caratteri e proprietà allo stesso modo in cui esso può volgersi alla realtà esterna. Si tratta piuttosto di un riferimento che in quanto richiede ognora un decidere intorno al proprio essere, è di tipo eminentemente pratico. (VOLPI, 2010, p. 61, grifos no original).
}

\footnotetext{
${ }^{138}$ Ao tratar especificamente da felicidade no fragmento 1177a, linhas 12 a 25 (parte do Livro X da Ética a

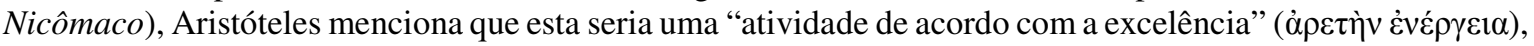
e, pela sua própria constituição, deveria ser uma atividade que ocorre de acordo com a mais poderosa das

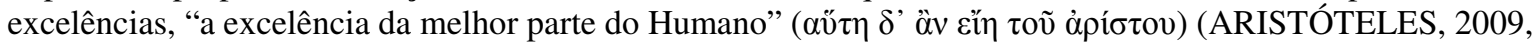
p. 234). E qual seria essa atividade? "Uma tal atividade é, como dissemos, contemplativa. [...] esta atividade é ela própria a mais poderosa que existe (porque o poder de compreensão intuitiva é o que de mais poderoso existe em nós, e os objetos mais excelentes que podem ser conhecidos são aqueles a que o poder de compreensão intuitiva acede) e é também a mais contínua de todas, porquanto nós somos capazes de nos demorarmos mais no olhar contemplativo do que na execução de qualquer outra ação." (ARISTÓTELES, 2009, p. 234-235)
} 
Vimos acima que a determinação unitária do Dasein é encontrável na cura (Sorge) (HEIDEGGER, 2012, p. 260-261) a qual, por seu turno, também é o modo fundamental da abertura (Esrchlossenheit) (VOLPI, 2010, p. 62). E esta correlação é importante pois:

\footnotetext{
[...] si comprende pure meglio perché Heidegger denoti in generali il riferirsi dell'esserci alle cose come un prendersi cura (Besorgen) - in cui la Zuhandenheit e la Vorhandenheit hanno il loro fondamento unitario - e il riferirsi dell'esserci agli altri come un avere cura (Fürsorge); lo si capisce meglio, giacché si sa ora che tutte queste determinazioni dell'esserci hanno in comune il carattere pratico della 'cura' per la ragione che l'essere stesso dell'esserci ha una connotazione eminentemente pratica. (VOLPI, 2010, p. 62).
}

Assim, nos parece claro que outro elemento central para o desenvolvimento de Ser e tempo é o conceito de abertura (Esrchlossenheit), como é possível notar dos próprios excertos e comentários acima. Com efeito, Heidegger chega a afirmar expressamente que a "presença é a sua abertura" (HEIDEGGER, 2012, p. 192).

Mas para que possamos haurir a pujança filosófica deste conceito heideggeriano, novamente temos que nos volver para Aristóteles, principalmente para a correlação possível entre a verdade e a própria busca por melhor entendimento acerca do que seria esta abertura do Dasein.

Com efeito, um dos significados fundamentais do ser para Aristóteles seria o serverdade (on hos alethes). Sobre o assunto, não é demais ressaltarmos, o Estagira trabalha em renomados fragmentos da Metafísica, um localizado no Livro E (fragmento 1027b) e outro localizado no Livro $\Theta$ (fragmentos 1051 b e 1052a).

No primeiro fragmento (1027b; linhas 18-27), Aristóteles salienta que tanto o serverdadeiro quanto o seu oposto (ser-falso) dizem respeito especificamente a um processo de conjunção/ligação $(\sigma u ́ v \theta \varepsilon \sigma ı \varsigma)$ e outro de separação ( $\delta ı \alpha i ́ \rho \varepsilon \sigma ı \varsigma)$, cuja fonte e resultado estariam localizados no pensamento, e não nas coisas em si.

Desta forma, seria necessária a participação de uma mente (intellectus) para unir e separar os conceitos, a qual no final das contas acabaria por identificar se o conceito de fato 
estaria unido ou separado à coisa (o que o tornaria verdadeiro) ou se o conceito estaria contradizendo a união/separação factualmente detectável (tornando-o, assim, falso).

O ser-humano, em resumo, dependeria apenas dos processos de conjunção e separação (meramente intelectivos) para então alcançar a verdade. Neste sentido, importante transcrevermos parte do fragmento acima mencionado para que não paire dúvida sobre o tema:

\footnotetext{
Quanto ao ser como verdadeiro e ao não-ser como falso, devemos dizer que se referem à conjunção e à divisão de noções e ambos envolvem as duas partes da contradição [lógica]. O verdadeiro é a afirmação do que é realmente unido e a negação do que é realmente separado; o falso é a contradição dessa afirmação e dessa negação. [...] De fato, o verdadeiro e o falso não se encontram nas coisas (como se o bem fosse o verdadeiro e o mal fosse o falso), mas só no pensamento; [...]. (ARISTÓTELES, 2013, p. 281)
}

E foi a partir de tais construções que a tradição filosófica criou o significado de verdade como adequação ou correlação, sumarizado na escolástica fórmula que trata a verdade como sendo uma "adaequatio intellectus et rei"139.

A verdade passou, em suma, a ser tratada na prática quase como uma operação lógico-proposicional, em que se buscava uma adequação/correlação entre a coisa e a mente do sujeito teorizador mediante a utilização do cálculo proposicional e demais elementos do aparato teórico e funcional da lógica (tanto a maior - em tese, material - quanto a menor meramente formal). Não é à toa que boa parte da jusfilosofia tende a restringir a análise do ser-jurídico a uma análise linguístico-proposicional.

De qualquer maneira, como afirmado por Heidegger, a "caracterização da verdade

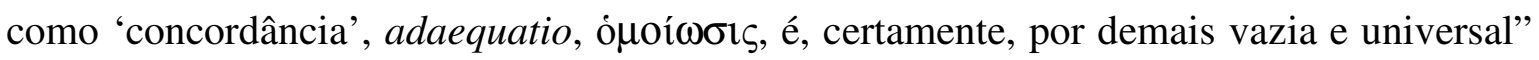
(HEIDEGGER, 2012, p. 285, grifos no original). Afinal, o que significaria o termo ‘concordância'? Quem determinaria, a princípio universalmente, que a correlação proposta

139 “Tomás de Aquino, que remete sua definição a Avicenna, que, por sua vez, remete ao Livro das definições (século X) de Isaak Israelis, também usou para adaequatio (adequação) os termos correspondentia e convenientia." (HEIDEGGER, 2012, p. 285, grifos no original). 
estaria de fato adequada? Se há correlação, deve haver uma base de comparação. E quem a definiria?

Ademais, como determinar que a definição é de fato adequada? Como justificar a validade desta concordância, que a princípio teria de ser una e constante? Ao elevarmos a mera (e idealista) concordância/adequação entre coisa e intelecto ao nível de fundamento para a verdade, não estaríamos esvaziando-a de sua originariedade e praticidade ética?

Não são irrelevantes os ensinamentos de Heidegger sobre o tema:

A concordância de algo com algo tem o caráter formal da relação de algo com algo. Toda concordância e, assim também, toda 'verdade' é uma relação. [...] Ao se esclarecer a relação de verdade, deve-se também considerar a especificidade dos membros da relação. Em que perspectiva intellectus e res concordam? (HEIDEGGER, 2012, p. 286, grifos no original).

E Heidegger deixa às claras sua suspeita acerca da possibilidade de se construir um discurso filosófico de fato viável a partir da acepção escolástico-tomista-cartesiana de verdade, dadas suas inconsistências próprias e riscos de mero formalismo/idealismo em que pode haver inclusive uma ausência de um referente ôntico (real simplesmente dado), como ocorre com o modalismo e a lógica meramente proposicional:

Segundo a opinião geral, só o conhecimento é verdadeiro. Conhecer, porém, é julgar. Em todo julgamento, deve-se distinguir a ação de julgar enquanto processo psíquico real e o conteúdo julgado enquanto conteúdo ideal. [...] O conteúdo ideal dos juízos é, pois, o que se acha numa relação de concordância. [...] Como se deve apreender ontologicamente a relação entre o ente ideal e o real simplesmente dado? Essa relação subsiste e consiste em juízos fáticos não somente entre o conteúdo do juízo e o objeto real, mas também entre o conteúdo ideal e ação real de julgar; e aqui a relação não será manifestamente mais 'intrínseca”? (HEIDEGGER, 2012, p. 287, grifos no original).

E conclui no item "a" do $§ 44$ da sua magnum opus:

E a separação entre a realização real e o conteúdo ideal não será ilegítima justamente no tocante à ação "real" de julgar alguma coisa? Não será que a 
realidade do conhecimento e do juízo se rompe em dois modos de ser ou “camadas", cuja sutura jamais chegará a alcançar o modo de ser do conhecimento? $[\ldots]$

Na questão sobre o modo de ser da adaequatio, apontar para a cisão entre conteúdo do juízo e acão de julgar não levará a discussão muito adiante. (HEIDEGGER, 2012, p. 287, grifos nossos).

Com efeito, com tais questionamentos e discussões, o que Heidegger está tentando fazer é polemizar com a própria interpretação do conceito de verdade tradicionalmente atribuída a Aristóteles em vista da hermenêutica escolástico-tomista-cartesiana criada em torno do disposto no Livro E da Metafísica (verdade enquanto concordância, adaequatio).

Para tanto, Heidegger busca uma interpretação mais originária e seminal (Ursprung; radical; transcendental) do conceito de verdade, em que esta apofanticamente demonstra a si mesma por um processo muito mais intuitivo do que proposicional.

Os ensinamentos de Franco Volpi neste sentido são muito claros e seguem exatamente o caminho hermenêutico ora proposto:

\footnotetext{
Polemizzando con le interpretazioni del problema della verità in Aristotele date da Schwegler, Jaeger e Ross, [...], Heidegger rivaluta le interpretazioni più sensibili ai problemi filosofici come quelle di Tommaso d'Aquino, di Suarez e di Bonitz. Con queste [Tommaso d'Aquino, di Suarez e di Bonitz] e contro quelle [Schwegler, Jaeger e Ross], egli [Heidegger] mette in evidenza come nel decimo capitolo del IX libro della Metafisica venga pensata una connessione essenziale tra il problema dell'essere e il problema della verità e, inoltre, come in questo contesto venga alla luce, nella determinazione greca del conoscere, l'originarietà e la fondamentalità dell'intuire. (VOLPI, 2010, p. 53).
}

No começo do capítulo 10 do Livro $\Theta$ (mais especificamente, no fragmento 1051b, linhas 2-9) Aristóteles inicialmente repete a mesma construção sugerida no Livro E. Assim, o "ser verdadeiro e falso das coisas consiste na sua união ou na sua separação, de modo que estará na verdade quem considera separadas as coisas que, efetivamente, são separadas e unidas as coisas que, efetivamente, são unidas [em pensamento]" (ARISTÓTELES, 2013, p. 429). 
Mas o Estagira traz agora elementos adicionais, de suma importância para nossas conclusões, que não apareceram no Livro E.

Com relação aos seres que nunca podem ser diferentes do que são

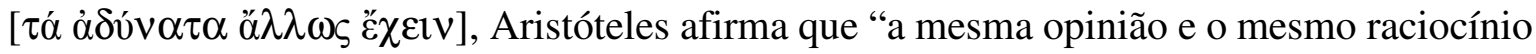
não podem se tornar ora verdadeiros, ora falsos, mas são sempre verdadeiros ou sempre falsos" (ARISTÓTELES, 2013, p. 429).

Levando em consideração que o próprio Aristóteles, ao apresentar o seu terceiro (e principal) significado para conteúdo do ser-necessário ${ }^{140}$ (pelo qual "é necessário que seja assim o que não pode ser diferente do que é"), parece-nos claro que todos os seres imbuídos daquela "linguagem da necessidade" obrigatoriamente seriam unidirecionais, isto é, não comportam a possibilidade de serem verdadeiros e falsos, ao mesmo tempo ${ }^{141}$.

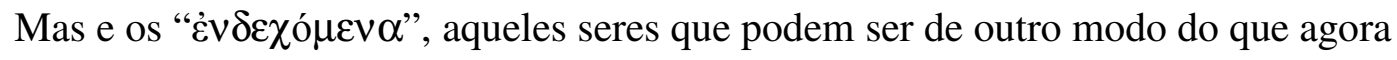
são? Aristóteles não titubeia ao declarar que, no caso dos " $\varepsilon \vee \delta \varepsilon \chi o ́ \mu \varepsilon v \alpha$ ", "a mesma opinião

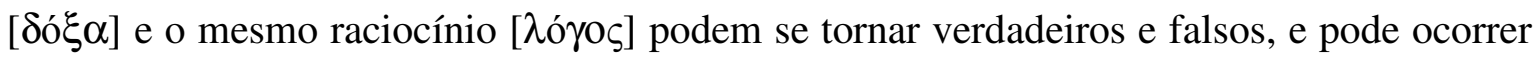
que, às vezes se afirme o verdadeiro e, às vezes, o falso" (ARISTÓTELES, 2013, p. 429).

A possibilidade de contradição aparenta ser, desta forma, ontologicamente ínsita

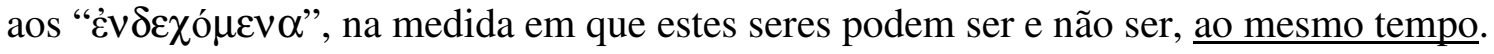

E o Estagira vai além, ao detalhar no Livro $\Theta$ uma distinção que também não fora trabalhada no Livro E: a diferenciação entre se buscar a verdade dos seres compostos/sintéticos ( $\sigma 0 ́ v \theta \varepsilon \tau \alpha)$ daquela encontrável nos seres não-compostos/assintéticos $(\alpha \sigma v ́ v \theta \varepsilon \tau \alpha)$.

Como exemplos de seres sintéticos/compostos o próprio Aristóteles menciona a conjunção/união ( $\sigma u ́ v \theta \varepsilon \sigma ı \varsigma)$ advinda da frase "a madeira é branca": afinal, podemos

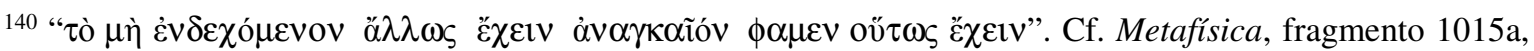
linhas 34-35.

${ }^{141}$ Afinal, " $2+2=4$ " é uma expressão de verdade que não pode ser diferente do que é (não pelo menos em uma matemático tradicional).
} 
considerar com certa facilidade que o ser-madeira é algo separável do conceito de serbranco, razão pela qual sua conjunção ( $\sigma u ́ v \theta \varepsilon \sigma ı)$ ) redunda em um ser-composto/sintético ${ }^{142}$.

Por outro lado, Aristóteles fornece como exemplo de seres assintéticos (nãocompostos) a circunferência do círculo ou a própria essência das coisas não-compostas

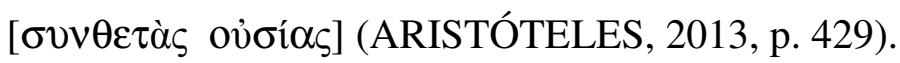

Mas qual seria a diferença entre os seres compostos e os não-compostos, quando estamos tratando de buscar a sua verdade?

O ser-verdade (o verdadeiro) nos seres não-compostos/assintéticos "é o fato de intuir e de enunciar ([sendo que] enunciação e afirmação, de fato, não são a mesma coisa) e o fato de não captá-los significa não conhecê-los."143 (ARISTÓTELES, 2013, p. 429). E complementa ainda sua percepção acerca dos $\alpha \sigma v ́ v \theta \varepsilon \tau \alpha$ afirmando que:

[...] o verdadeiro consistirá simplesmente em pensar esses seres [ $\alpha \sigma 0 ́ v \theta \varepsilon \tau \alpha]$; enquanto, a respeito deles, não exista falso e nem engano, mas apenas ignorância; e ignorância não semelhante à cegueira, porque a cegueira corresponderia ao não ter absolutamente a faculdade de pensar. (ARISTÓTELES, 2013, p. 429) ) $^{144}$

Em outra obra ${ }^{145}$, Aristóteles chega mesmo a afirmar (fragmento 430a, linha 26) que "o pensamento de objetos indivisos [ $\alpha \delta$ ı $\alpha \rho \varepsilon \tau o v]$ está entre os casos acerca dos quais não há o falso" (ARISTÓTELES, 2012, p. 117). Sobre referida passagem, Maria Cecília Gomes de Reis afirma que:

A expressão adiaireton pode ser traduzida por indivisível e por indiviso, mas é
esta segunda alternativa que funciona melhor no andamento do argumento
apresentado aqui. [...] O tipo básico de objeto inteligível em que Aristóteles se

${ }^{142}$ Chama-nos a atenção que Kant chegou a uma ideia (e nomenclatura) similar (ainda que não integralmente assimilada) ao criar sua teoria em torno dos juízos sintéticos e dos juízos analíticos, base de toda sua Crítica.

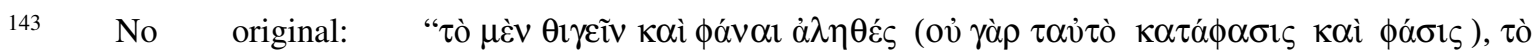

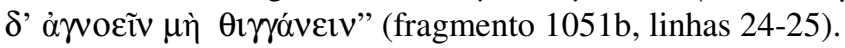

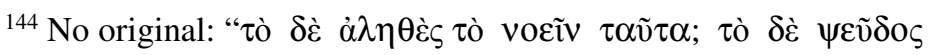

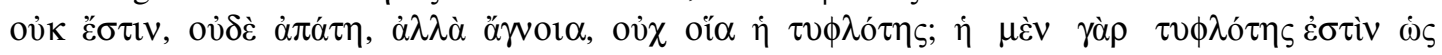

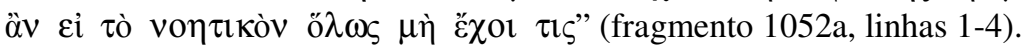

145 ARISTÓTELES. De Anima. Tradução de Maria Cecília Gomes de Reis. - 2a ed.. São Paulo: Editora 34, 2012. 
concentra neste capítulo se liga ao que ele designou, em Met. 1051b17-1025a4, como ta asyntheta - isto é, objetos inteligíveis não compostos. [...]

É razoavelmente seguro interpretar [...] que, em relação à intelecção de noções básicas e de termos simples, ou se chega ao pensamento do conceito, ou este não se realiza e perdura a ignorância. A verdade é a simples apreensão do inteligível, e não apreendê-lo é ignorância, [...]. (ARISTÓTELES, 2012, p. 309-310).

Em resumo, tal como atestado por Volpi ao aprofundar a interpretação de Heidegger acerca do sentido do ser-verdadeiro obtido dos fragmentos acima, constantes no Livro $\Theta$ :

Com'è noto, il testo aristotelico in questione tratta il problema della determinazione dell'essere. [...].

Quanto agli enti composti, essi possono essere tali in due modi: (1) sempre (aei on, adynata allos echein), e allora il logos che li collega sarà o sempre vero, se li unisce quando sono uniti e li separa quando sono separati, oppure sempre falso, se li unisce quando sono separati e li separa quando sono uniti; oppure (2) a volte sì e a volte no (ta endechomena allos), e allora il logos che li collega potrà essere a volte vero e a volte falso.

Per quanto riguarda inveci gli enti non composti (asyntheta), essi non possono essere colti nel discorso collegante, nella syntehsis o nella dihairesis, cioè nella sttrutura predicativa del qualcosa in quanto qualcosa. La loro verità è diversa rispetto all'essere vero o falso della predicazione. Per Heidegger, Aristotele coglie qui la verità come carattere dell'ente stesso, [...]. La verità in questo senso può essere colta nell'apprensione diretta del noein (vernehmen, Vernunft) che Aristotele designa come un 'toccare' (thigein, thigganein). Intorno ad essa non vi è errore, come nella predicazione, mas semplicemente un non coglimento, un non conoscere (agnoein), nel senso che o la si coglie nella sua tangibilità o non la si coglie affatto. (VOLPI, 2010, p. 53-54, grifos no original).

Assim, acreditamos que a interpretação da veritas enquanto adaequatio reflete, no final das contas, uma circunvisão calcada em um limitado modelo cartesiano de interpretação do eu e da existência (apoiado que se encontra no descomedido elogio racionalista ao ego, característico da Era Moderna) que privilegiaria a lógica do enunciado proposicional em contraste à verdade intuitivo-fenomenológica.

Neste diapasão, Heidegger afirma que: 
O enunciado é verdadeiro significa: ele descobre o ente em si mesmo. Ele enuncia, indica, 'deixa ver' ( $\alpha \dot{\pi} \hat{\phi} \phi \alpha v \sigma \iota \varsigma)$ o ente em seu ser e estar descoberto. O serverdadeiro (verdade) do enunciado deve ser entendido no sentido de serdescobridor [entdeckend-sein]. A verdade não possui, portanto, a estrutura de uma concordância entre conhecimento e objeto, no sentido de uma adequação entre um ente (sujeito) e um outro ente (objeto).

Enquanto ser-descobridor, o ser-verdadeiro só é, pois, ontologicamente possível com base no ser-no-mundo. Esse fenômeno, em que reconhecemos uma constituição fundamental da presença, constitui o fundamento do fenômeno originário da verdade. (HEIDEGGER, 2012, p. 289, grifos nossos).

E tornando ainda mais evidente a correlação entre ser-verdadeiro e os momentosmovimentos envoltos na ideia de abertura (Erschlossenheit), Heidegger não poderia ser mais contundente:

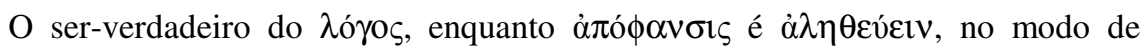

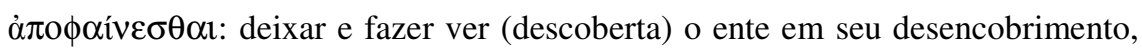
retirando-o do encobrimento. A $\dot{\alpha} \lambda \dot{\eta} \theta \varepsilon \iota \alpha,[\ldots]$, indica as "coisas elas mesmas", o que se mostra, o ente na modalidade de sua descoberta. [...] Pertence, pois, ao

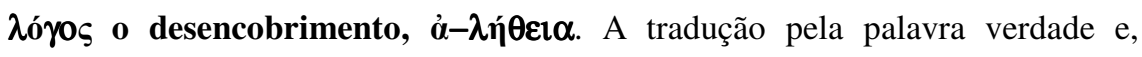
sobretudo, as determinações teóricas de seu conceito encobrem o sentido daquilo que os gregos, numa compreensão pré-filosófica, estabeleceram como fundamento 'evidente' do uso terminológico de $\dot{\alpha} \lambda \hat{\eta} \theta \varepsilon 1 \alpha$. (HEIDEGGER, 2012, p. 290, grifos nossos).

E conclui:

Ser-verdadeiro enquanto ser-descobridor é um modo de ser da presença. [...] Descobrir é um modo de ser-no-mundo. A ocupação que se dá na circunvisão ou que se concentra na observação descobre entes intramundanos. São estes o que se descobre. [...] a descoberta dos entes intramundanos funda-se na abertura de mundo. Abertura, porém, é o modo fundamental da presença segundo o qual ela é o seu pre. A abertura constitui-se de disposição, de compreender e de fala, referindo-se, de maneira igualmente originária, ao mundo, ao ser-em e ao ser-simesmo. A estrutura da cura enquanto anteceder-a-si-mesma-no-já-estar-nummundo-como ser-junto aos entes intramundanos, resguarda em si a abertura da presença. Com ela e por ela é que se dá a descoberta. Por isso, somente com a abertura da presença é que se alcança o fenômeno mais originário da verdade. 
[...] A presença é e está 'na verdade'. (HEIDEGGER, 2012, p. 291, grifos no original).

Em síntese, a análise acima foi feita com o intuito de tentar aclarar a posição central que o conceito de abertura tem para Heidegger, e para toda a ontologia de caráter fenomenológico consequentemente. A abertura (enquanto momento-movimento em que o

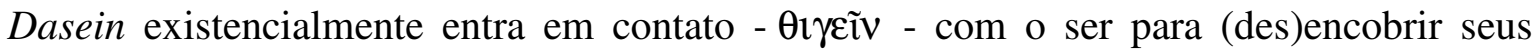
elementos significativos) passa a pertencer desta maneira à constituição, à estrutura ontológica mais própria do ser do Dasein (HEIDEGGER, 2012, p. 292).

E o mais importante: a abertura do Dasein, que é essencial e constitutivamente $\pi \rho \alpha \xi_{1 \zeta}$, em seus momentos-movimentos pelos quais (des)encobre o ser, nada mais é do que uma busca pela verdade do ser, uma verdade que não está ferrenhamente agrilhoada ao modalismo e à lógica-proposicional (carregados que se encontram daquela "linguagem da necessidade" que tratamos acima), mas uma verdade intuitiva e, no final, constitutivamente poética.

Não é demais salientarmos que o momento-movimento de (des)encobrimento do ser é duplo, na medida em que a abertura pode tanto encobrir como desencobrir a verdade dos entes, a depender da própria configuração de mundo e da circunvisão detidas pelo Dasein. Apenas para referendarmos este ponto de maneira pontual, mais uma vez Heidegger:

\footnotetext{
Aristóteles jamais defendeu a tese de que o "lugar" originário da verdade fosse o

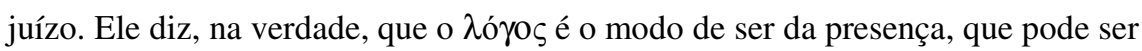
descobridor ou encobridor. Essa dupla possibilidade é o que há de surpreendente no ser-verdadeiro do $\lambda \hat{\gamma} \gamma \mathrm{s}$, pois este é o relacionamento que também pode encobrir. [...] A tese de que o "lugar" genuíno da verdade é o juízo não apenas é erroneamente atribuída a Aristóteles como constitui, no que respeita a seu conteúdo, um desconhecimento da estrutura da verdade. (HEIDEGGER, 2012, p. 122 , grifos no original).
}

Nesta toada, as proposições linguísticas em geral não podem ser consideradas como o "lugar" originário em que se pode buscar a verdade. Não podemos considerar que as meras palavras da lei positiva, ainda que interpretadas ou aplicadas, também sejam o "lugar" originário em que se pode buscar a verdade do fenômeno jurídico. 
Tais proposições linguísticas, incluindo as de caráter normativista, são simples elementos narrativo-mitológicos pelos quais a apropriação da descoberta ocorre pela presença, fundando-se na própria abertura do Dasein por ser um modo de ser-no-mundo (HEIDEGGER, 2012, p. 297). A verdade, com viés intuitivo e originário, é assim a “condição ontológica de possibilidade para que o enunciado possa ser verdadeiro ou falso (possa ser descobridor ou encobridor)." (HEIDEGGER, 2012, p. 297).

No diuturno confronto com os seres intramundanos (incluindo outras presenças na medida em que são consideradas seres-humanos), o Dasein sente a verdade, a qual é interpretada quando a presença, tomando posse dos fenômenos, deles arranca verdade, por meio do qual os entes, sejam eles quais forem, são (des)encobertos.

A verdade, em resumo, deixa de possuir aquele caráter unidimensional, unidirecional e (pré)destinado que o ser-necessário (ou sua "linguagem da necessidade") tradicionalmente demanda, possuindo facetas variadas, resultando em possibilidades inesperadas em relações que muitas vezes são mais instáveis e hesitantes do que muitos gostariam que fossem.

A verdade jamais pode ser eterna ${ }^{146}$, mas pode ser descoberta ${ }^{147}$. Como poderíamos então (des)cobrir a verdade do fenômeno jurídico?

\subsection{O fundamento do ser-jurídico é o poder-ser existencial (decisional)}

Já mencionamos nesta Dissertação, a título ilustrativo, a personagem criada pelo escritor Neil Gaiman (Destino) para representar, antropomorficamente, o fio-condutor capaz de ser usado para enxergar (des-cobrir) um conjunto em tese formado por todas as fatalidades, sinas, fortunas, felicidades e venturas humanas, as quais estariam

\footnotetext{
146 “Afirmar 'verdades eternas' e confundir a 'idealidade' da presença, fundada nos fenômenos, com um sujeito absoluto e idealizado pertencem aos restos da teologia cristã no seio da problemática filosófica, que de há muito não foram radicalmente eliminados." (HEIDEGGER, 2012, p. 301).

${ }^{147}$ Heidegger apresenta um exemplo que nos parece aclarar bem esta questão: "As leis de Newton, antes dele, não eram nem verdadeiras nem falsas. Isso não pode significar que o ente que elas, descobrindo, demonstram não existisse antes delas. As leis se tornam verdadeiras com Newton. Com elas, o ente em si mesmo se tornou acessível à presença. Com a descoberta dos entes, estes se mostram justamente como os entes que já eram antes delas. Descobrir assim é o modo de ser da 'verdade'." (HEIDEGGER, 2012, p. 298).
} 
consubstanciadas em diversas e ramificadas trilhas que, depois de "uma vida de caminhadas, você pode olhar para trás e ver apenas uma única trilha se estendendo às suas costas" (GAIMAN, 2011, p. 13).

O Destino de Gaiman caminha por seu brumoso jardim, lendo e relendo seu livro, um grande alfarrábio em que tudo já passado, passante e a passar estaria reproduzido, na forma de uma epopeica narrativa humana, de caráter totalizante.

Imaginemos que de fato exista um tal livro ${ }^{148}$, em que "tutto sia detto e scritto, per ciò che concerne la salvezza e la felicità degli uomini”" (ABBAGNANO, 1956, p. 5). Mas suponhamos que a língua e os caracteres utilizados em tal alfarrábio não sejam prontamente claros e acessíveis a todos; o livro é legível cá e acolá, mas não de maneira integral e nunca de forma a evitar dúvidas que sua (re)leitura pode dar azo (ABBAGNANO, 1956, p. 5).

\section{De qualquer modo:}

[...] noi metteremo a prova nella vita le indicazioni o i suggerimenti del libro; e se la prova riuscerà male, ritorneremo alle pagine del libro per leggere meglio $\mathrm{e}$ capire ciò che veramente esso dice e pretende da noi. E così continueremo, tra tentativi, errori, riletture, ricadute negli errori, avanzamenti o regressi, sempre nella fiducia che il libro ci offra la strada sicura e infallibile per tutte le faccende della vita e sempre più o meno delusi in questa fiducia. (ABBAGNANO, 1956, p. $5-6)$.

Contudo, uma (re)leitura um pouco mais atenta apresentaria um quadro bem diverso: ao invés de certezas indeléveis, o livro contém na realidade pouquíssimas coisas que poderiam ser dadas como certas, e mesmo estas não se poderia dizer que estão completamente a salvo de qualquer dúvida ou possibilidade de dúvida.

Assim, aquilo que seria determinado como bem-estar, segurança, paz, felicidade (e porquê não, como jurídico), em suma aqueles valores que normalmente criam/doam sentido para a vida humana (ABBAGNANO, 1956, p. 6), apresentam-se "sempre incerti e mutevoli,

\footnotetext{
${ }^{148}$ Passamos agora a utilizar certas alegorias criadas por Abbagnano quando este discursou, em janeiro de 1951, em uma conferência promovida pela Associação Cultural Italiana, e posteriormente publicada no seu livro Libertà e possibilità. Para maiores detalhes, cf. ABBAGNANO, 1956, p. 5 et seq.
} 
perché il gran libro non si lascia mai leggere chiaramente o perché anche ciò che leggiamo non riesce a illuminarci completamente" (ABBAGNANO, 1956, p. 6, grifos nossos).

E este tipo de instabilidade (ou hesitação, poderíamos dizer) causada por tais incertezas acaba sendo trazida a lume (i.e., sendo descoberta e sentida como existencialmente verdadeira) exatamente por não ser a verdade (ou melhor, os momentosmovimentos do Dasein em sua diuturna busca pela verdade - os seus quotidianos sendos) um elemento de configuração meramente enunciativa/ lógico-proposicional: sua força, muito pelo contrário, reside no múltiplo, no contraditório, no disforme, no poético, na aparente inocuidade e obviedade intuitiva do ser-humano e de suas decisões, em toda sua dramaticidade, dor, alegria e destemperos que lhes são mais característicos.

De qualquer maneira, o grande livro da existência precisa ser (re)lido e interpretado; suas projeções, (in)adequações e mitos clamam pela sua abertura no e pelo Dasein. Mas como se dá essa interpretação? Através do compreender existencialmente considerado, responderia Heidegger.

Com efeito, ao tratar do compreender interpretativo que é ontologicamente constitutivo à presença, Heidegger expressamente afirma que:

O que se pode no compreender, assumido como um existencial, não é uma coisa, mas o ser como existir. Pois no compreender subsiste, existencialmente, o modo de ser da presença enquanto poder-ser. A presença não é algo simplesmente dado que ainda possui de quebra a possibilidade de poder alguma coisa. Primariamente, ela é possibilidade de ser. (HEIDEGGER, 2012, p. 203, grifos nossos).

E continua declarando que:

Toda presença é o que ela pode ser e modo em que é a sua possibilidade. A possibilidade essencial da presença diz respeito aos modos caracterizados de ocupação [Besorgen] com o 'mundo', de preocupação [Fürsorge] com os outros e, nisso tudo, à possibilidade de ser para si mesma, em virtude de si mesma. (HEIDEGGER, 2012, p. 203, grifos nossos). 
Trazendo a questão para mais perto dos assuntos discutidos neste trabalho, entendemos não ser adequado tratar o ser-jurídico como algo que pudesse ser (des)coberto de antemão, mediante uma análise lógico-proposicional das leis e suas "interpretações autênticas”, até mesmo porque uma análise deste tipo, em que pese sua patente utilidade tecnológica e teológica (com todos os seus ritos e mitos) usualmente pouco agrega para a percepção do que seria o fenômeno jurídico, enquanto verdade social.

A percepção do fenômeno jurídico pela sociedade, com efeito, está muito mais ligada a um momento-movimento intuitivamente pré-compreendido e já-desde-sempreprojetado da (e pela) presença (Dasein), ficando muitas vezes totalmente borrada a linha de demarcação que se tenta fazer entre o que seria o ser-jurídico, o ser-ético, o ser-religioso, etc.

O ser-normativo, em suma, é algo cuja percepção depende da vivência, experiência, circunvisão e horizonte de movimentação temporalizada do Dasein, em toda a sua historicidade e temporalidade que lhe são afeitas, por meio de movimentos-momentos de pré-compreensão e de projeção da presença, em que (e pelo que) o ser-jurídico se (des)cobre, é tocado/intuído/revelado e enunciado como tal e tal como Aristóteles afirmou ocorrer ao

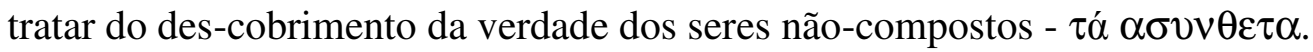

Nestes seres, o ser-verdade nada mais é do que a ação $\left(\pi \rho \alpha^{\xi} \xi 1 \varsigma^{149}\right)$ de "intuir e de enunciar ([sendo que] enunciação e afirmação, de fato, não são a mesma coisa)"

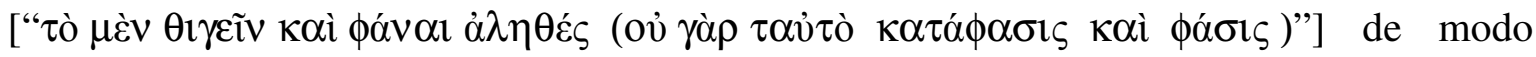

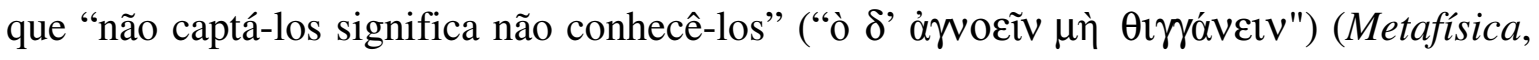
fragmento 1051b, linhas 24-25; De anima, fragmento 430a, linha 26).

E o ser-normativo segue o mesmo tipo de racional: sua percepção não é lógica e proposicionalmente enunciada ou construída; sua enunciação/construção depende intimamente de ter o Dasein (pre)compreendido-o (este ser) como normativo, projetando-

\footnotetext{
${ }^{149}$ Consideramos que a ação merece ser ressaltada no momento-movimento de descobrimento da verdade existencial-intuitiva à medida que o próprio Aristóteles não utilizou nomes ou formas nominais para descrever o que seria a verdade dos seres não-compostos ( $\tau \alpha \dot{\alpha} \alpha \sigma v v \theta \varepsilon \tau \alpha)$ ). De fato, ele usa formas verbais para descrever

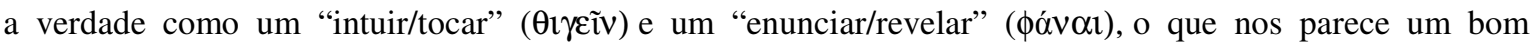
indicativo de como Aristóteles, e os gregos em geral, realmente não entendiam a verdade como algo estanque, mas sim um contínuo buscar.
} 


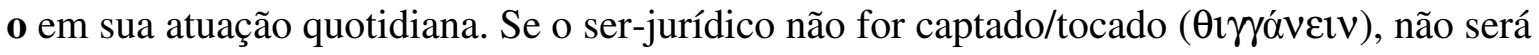
conhecido (ảyocĩv), e como tal não poderá ser jamais verdadeiramente enunciado pela presença: sua enunciação, desta forma, depende de sua revelação/intuição que, por outro lado, de tão dependente que é da circunvisão (Umsicht) e do horizonte do Dasein, acaba sendo impossível (e até mesmo indesejável) qualquer tentativa de definição (definitio) do que é ser-jurídico, ser-ético, ser-religioso, etc.

A verdade do ser-jurídico (e do ser-normativo em geral) está assim muito mais

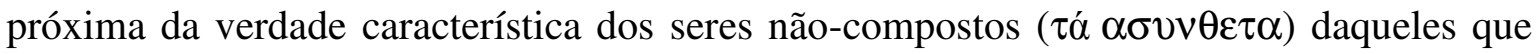
dependem de composição ou sintetização.

De qualquer maneira, e como esperamos ter deixado claro ao longo desta Dissertação, não consideramos como válida a apreensão do poder-ser que é o ser-normativo como ser-potência (por camuflar a necessidade com as vestes da possibilidade). Também entendemos vazia e insípida (e, muitas vezes, perigosa) a possibilidade meramente modal (lógico-proposicional). Nessa linha, compartilhamos com os ensinamentos de Heidegger sobre o assunto:

\begin{abstract}
A possibilidade de ser, que a presença existencialmente sempre é, distingue-se tanto da possibilidade lógica e vazia [a que chamamos de possibilidade meramente modal] como da contingência [a que chamamos de ser-potência] [...]. Como categoria modal do ser simplesmente dado, a possibilidade designa o que ainda não é real e que nunca será necessário. Caracteriza o somente possível. Do ponto de vista ontológico, é inferior à realidade e à necessidade. Como existencial, a possibilidade é, ao contrário, a determinação ontológica mais originária e mais positiva da presenca; $[. .$.$] . O solo fenomenal que permite a sua visão$ oferece o compreender como o poder-ser capaz de propiciar aberturas.

[...], a presença já caiu em determinadas possibilidades e, sendo o poder-ser que ela é, já deixou passar tais possibilidades, doando constantemente a si mesma as possibilidades de seu ser, assumindo-as ou recusando-as. [...] A presença é a possibilidade de ser livre para o poder-ser mais próprio. (HEIDEGGER, 2012, p. 203-204, grifos nossos).
\end{abstract}

E Heidegger continua a traçar melhor as principais características do poder-ser existencial, que em nossa concepção é o verdadeiro fundamento abissal para o fenômeno 
comportamental (que é, em suma, a mesma coisa que o ser-jurídico, enquanto précompreensão e projeção do - pelo - Dasein do que este considera como tal).

Enquanto abertura da presença, o movimento de (pré)compreensão sempre alcança toda a constituição fundamental do ser-no-mundo (HEIDEGGER, 2012, p. 205), e como “poder-ser, o ser-em é sempre um poder-ser-no-mundo" (HEIDEGGER, 2012, p. 205) em que este "não apenas se abre como mundo, no sentido de possível significância, mas a liberação de tudo que é intramundano libera esse ente para suas possibilidades" (HEIDEGGER, 2012, p. 205).

Assim, a força ontológica (e libertária) do poder-ser é o próprio compreender à medida que a "presença é de tal maneira que ela sempre compreendeu ou não compreendeu ser dessa ou daquela maneira" (HEIDEGGER, 2012, p. 204). Em outras palavras, ainda que não quisesse, o Dasein sempre, de uma maneira ou de outra, tem uma (pré)-compreensão do mundo que lhe circunda, seja ela qual for (mundo este que, na sua configuração de um continuum espaço-temporal, abarca também toda a narrativa mitológica própria de cada ser humano individualmente considerado, incluindo sua narrativa ético-comportamental), antecipando-o e projetando-o em seus afazeres quotidianamente considerados.

O Dasein, ao compreender o ser (incluindo, por óbvio, o ser-jurídico), "projeta o ser da presença” (HEIDEGGER, 2012, p. 205) sendo que:

\footnotetext{
O projetar-se nada tem a ver com um possível relacionamento frente a um plano previamente concebido, segundo o qual a presença instalaria o seu ser. $\underline{\text { Ao }}$ contrário, como presenca, ela já sempre se projetou e só é em se projetando. Na medida em que é, a presença já se compreendeu e sempre se compreenderá a partir de possibilidades. ${ }^{150}$ (HEIDEGGER, 2012, p. 205, grifos nossos)
}

\footnotetext{
${ }^{150}$ Não podemos olvidar que dentre todas as possibilidades existenciais, a "morte é a possibilidade mais própria da presença" HEIDEGGER, 2012, p. 340, grifos no original). Como afirmado por Volpi, tudo o que existe como um puro ser-possível, "può, ad ogni istante, non essere." (VOLPI, 1956, p. 14). Desta feita, se a existência humana “è, nel suo complesso, un possibile, la possibilità del non essere l'acompagna e la definisce. Questa possibilità del non essere è ciò che tutti intendiamo con la parola 'morte'." (VOLPI, 1956, p. 14). Assim, a morte "non è, da questo punto di vista, la conclusione di un ciclo, un termine, una fine, un fatto localizzabile in un momento dato e che perciò caratteriza solo questo momento e non gli altri. È invece una possibilità sempre presente all'esistenza umana." (VOLPI, 1956, p. 14). Contudo, temos que para o deslinde de nossa argumentação, não acrescentaríamos muito se prolongássemos nossa análise para o fim de sublinhar a pujança que a morte tem para a presença: ainda que ontologicamente impregnada como ser-para-a-morte (antecipandoa), a presença usualmente (a par de estados de exceção schmittianos) não chega a quotidianamente analisar e
} 
E esse é o fundamento abissal do fenômeno normativo, analisado sob o ângulo da Guilhotina de Hume (pensada ontológica e fenomenologicamente): (i) vimos no começo a vinculação estreita entre a ideia de dever-ser, norma jurídica, linguagem e o ser necessário, em que este é utilizado como fundamento originário para o fenômeno jurídico, o que contestamos por entendermos que o direito fenomenal jamais poderia se identificar com algo

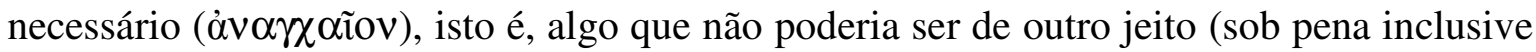
de ignorarmos todas as variações jurídicas e existentes ao longo da história e ainda no tempo atual); (iii) assim, se não é dever-ser (ser-necessário, em seu fundo ontológico), só o ser poderia fundamentar o direito (ou a ética ou a religião, etc.) mas dentre os muitos modos que o ser se revela, qual deles é o Ur-sprung Ab-grund do fenômeno jurídico?

É o poder-ser. Mas não no viés de ser-potência ou meramente modal (lógicoproposicional). Em seu sentido existencial e decisional mais próprio.

Afinal, a existência não é um laboratório higienizado no qual o caminho a ser perseguido e trilhado pela presença encontra-se científica e objetivamente à disposição para ser analisado, caminhos estes que estes que estão longe de seguir a lógica do ser-necessário. A existência não é, muito menos ainda, um templo jurídico em que os seus iniciados (e, na prática, somente eles) têm acesso à verdade jurídica, sabendo (mediante uma tecnicidade ritualístico-mitológica que lhe é própria) inclusive como distinguir o direito da moral, a moral da ética, esta da religião, e por aí vai.

A existência, no final de todas as contas e em que pese todos os pesares, é possibilidade (de ser e não ser). Possibilidade esta sumarizada e constitutivamente amalgamada na ideia de liberdade, pura e simples, sendo a presença (Dasein), para tanto, tão livre quanto. Neste sentido, Heidegger explica que em existindo, "a presença é o fundamento

aprofundar os efeitos que o projetar de sua morte teria em suas decisões. Vamos considerá-la, por ora, apenas como mais um elemento narrativo-comportamental (que cada um absorverá e promoverá conforme queira/possa, segundo sua disposição usualmente disposta - ह̌ $\xi 1 \varsigma /$ habitus) que obviamente influencia o modo pelo qual as decisões são tomadas, mas não tencionamos torná-la como bússola de orientação principal para compreensão do ser-jurídica (como Heidegger fez em sua magnum opus ao tratar da óbvia, claudicante e lancinante finitude da presença). 
de seu poder-ser porque só pode existir como o ente que está entregue à responsabilidade ${ }^{151}$ de ser o ente que ela é.” (HEIDEGGER, 2012, p. 364, grifos no original).

E arremata declarando que:

\begin{abstract}
Existindo, a presença é seu fundamento, ou seja, é de tal modo que ela se compreende a partir de possibilidades e, assim se compreendendo, é o ente lançado. Isso implica, no entanto, que: podendo-ser, ela está sempre numa ou noutra possibilidade, ela constantemente não é uma ou outra e, no projeto $\underline{\text { existenciário, recusa uma ou outra. [...] A liberdade, porém, apenas se dá na }}$ escolha de uma possibilidade, ou seja, implica suportar não ter escolhido e não poder escolher outras. (HEIDEGGER, 2012, p. 365, grifos nossos)
\end{abstract}

Assim, temos que considerar como pressuposto de toda a nossa discussão que estas premissas (a existência é, em suma, possibilidade e liberdade, as quais ontologicamente fundamentam-se de maneira originária) sejam em si, intuitiva e poeticamente, verdadeiras, caso contrário estaríamos obrigados a retornar à ideia de que o Destino (sic), antes de ser um peripatético decifrador de um código comportamental - deveras complexo - passaria a ser um mero observador do que já se sabe vai ocorrer, necessariamente.

Considerar o destino (sic) como imutável, é considerar como verdadeira (e unicamente verdadeira) a "linguagem da necessidade", contra qual tanto combatemos ao longo desta Dissertação.

Assim sendo, as incertezas, dúvidas e (des)venturas que se encontram detalhadas nos caracteres daquele grande livro da vida fazem com que:

[...] tutto ciò che noi facciamo in un qualsiasi campo e il nostro essere, vale a dire ciò che noi stessi siamo, non è dettato in modo preciso e infallibile da quegli stessi caratteri. Il libro non ci illumina mai completamente, questo è vero, ma per ciò

\footnotetext{
151 Merece destacarmos que Heidegger fundamenta a presença também no fato de que ela, cotidiana e constitutivamente, está sempre em dívida/débito (Schuld) consigo mesma. Muito embora Heidegger insista no $\$ 58$ da sua magnum opus que o conceito de dívida/débito em sua obra não deva ser entendido "moralteologicamente como culpa", como a Professora Márcia Schuback leciona (HEIDEGGER, 2012, p. 579, nota 77 da tradutora), temos a impressão que o conceito de fato está impregnado indissoluvelmente com o conceito de culpa, com todo o arcabouço teológico (de fundo abraâmico), que por ora não pretendemos investigar a fundo, sob pena de escapulirmos do objeto desta Dissertação.
} 
non ci dirige neppure mai completamente, non ci necessita ad essere e a fare quello che facciamo e siamo. È evidente che se potessimo leggervi tutto, tutto sarebbe determinato e necessitato da esso; ma poiché non possiamo leggervi tutto, rimane sempre per noi un margine per cui possiamo essere ad ogni agire in um modo o nell'altro: un margine di scelta, un margine di possibilità indecise. Ma poiché questo margine non è localizzato in questo o quel rigo del libro, cioè in questo o quel punto della realtà che ci interessa, ma accompagna ogni suo rigo e ogni aspetto di questa realtà, noi siamo da un capo all'altro della lettura, e cioè per tutta la durata della nostra vita, liberi. (ABBAGNANO, 1956, p. 8-9, grifos nossos).

A liberdade, assim, há de ser considerada portanto como um aspecto fundamental da nossa própria humanidade; ela é constitutiva da presença. Mas, de qualquer maneira, não se trata de uma liberdade ampla e irrestrita. Ninguém pode ser tudo o que quer, como quer, a qualquer momento. Há (re)condicionamentos e condicionantes para tanto.

De fato, a liberdade humana é muito mais limitada. Como afirmado por Abbagnano:

La libertà di cui, come essere umani, siamo dotati e che, per quel che ho detto, dev'essere considerata come l'aspetto fondamentale dela nostra umanità, è sempre una libertà di scelta delimitta, che ci pone davanti continuamente ad alternative. [...] Il poter fare o il poter essere costituisce la condizione indispensabile affinché ciascuno di noi compia le sue scelte e prenda le sue decisioni. [...] il punto che voglio qui sottolineare è soltanto questo: libertà significa scelta e scelta significa possibilità. [...] Sul può essere si fonda l'intera esistenza umana. Questa esistenza, anzi, non è altro che un può essere. (ABBAGNANO, 1956, p. 10-11, grifos nossos).

Há, desta forma, uma ligação $(\sigma u ́ v \theta \varepsilon \sigma ı \varsigma)$ ontologicamente constitutiva entre o Dasein (a presença), a sua liberdade e a decisão (existencial, no sentido de não estar adstrita meramente à decisão jurídica, usualmente o único foco das teorias que tratam da decidibilidade ${ }^{152}$ ).

Nos dizeres de Franco Volpi, ao tentar aprofundar seu entendimento acerca daquela conotação prática inerente ao Dasein, Heidegger:

${ }^{152}$ Cf. FERRAZ JÚNIOR, 1994, mormente o capítulo 6 da referida obra. 
[...] si interroga [...] sul fondamento di questa connotazione pratica dell'esserci; egli si chiede, cioè, quale sia il carattere ontologico di fondo dell'esserci sul quale essa poggia. La risposta che egli dà a questo interrogativo è che l'essere dell'esserci non è qualcosa di meramente puntiforme e attuale, ma un poter-essere che si dilata oltre i confini della propria attualità, sia in direzione del futuro, nell progetazzione e nell'attuazione del suo essere, sia in direzione e orizzonte del suo progettare. Il poter-essere è così un 'essere sospeso' dell'esserci che è la dimensione ontologica della sua libertà, del suo essere-libero-per; [...].(VOLPI, 2010, p. 63).

E como esse "ser suspenso" que é o poder-ser, nos dizeres de Volpi, materializase? Voltando à citação já feita acima, a liberdade "apenas se dá na escolha de uma possibilidade, ou seja, implica suportar não ter escolhido e não poder escolher outras [possibilidades]" (HEIDEGGER, 2012, p. 365), sendo que, como também já mencionamos, este é o "aspetto negativo e nullificante di tutte le possibilità che ci sono offerte" (ABBAGNANO, 1956, p. 16), em que o poder-ser, em si e por si, prevê a sua própria nulificação. Nulificação do ser-possível que ocorre com a própria decisão/escolha que lhe é constitutiva, em toda sua finitude, pré-compreensão e projeção ${ }^{153}$.

E já podemos agora tratar mais pontualmente de uma questão que deixamos subjazendo ao longo desta Dissertação: a decisão (abertura do poder-ser, não sua necessária realização) não é a decisão meramente jurídica, tal como usualmente a questão é tratada. A decisão não é feita apenas pelas (e para) tecnossacerdotisas e pelos (e para) tecnossacerdotes do direito: a decisão é humana, quotidiana e basicamente independe de formação

\footnotetext{
${ }^{153}$ Para condensar nosso posicionamento acerca dos principais temas envolvidos ao tratarmos da possibilidade existencial, podemos fazer uso do rol trazido pelo Professor Róbson Ramos dos Reis acerca dos temas que lhe são afeitos, que seriam: "1) as possibilidades perfazem as determinações da existência, que não é adequadamente descrita por propriedades, mas sim por modos ou maneiras; 2) o primado do possível sobre efetividade e necessidade; 3) a relatividade das possibilidades às projeções compreensivas; 4) a incompatibilidade entre a qualificação existencial e a tematização da possibilidade; 5) a modificação de segunda ordem das possibilidades, definindo as noções de propriedade (autenticidade) e impropriedade (inautenticidade); 6) a inserção da possibilidade existencial no todo estrutural referido pela noção de cuidado (Sorge), definindo a fonte das projeções como sendo uma herança recebida e a presentificação de entes e objetos como sendo dependente da projeção em possibilidades; 7) a relação entre possibilidade existencial, temporalidade originária (com a primazia no futuro) e historicidade; 8) a finitude das projeções em possibilidades e a negatividade do possível." (REIS, Róbson Ramos dos. Aspectos da modalidade: a noção de possibilidade na fenomenologia hermenêutica. Rio de Janeiro: Via Vérita, 2014, p. 76). Cabe uma nota sobre o rol acima: é de se ressaltar que ao longo desta Dissertação não usamos a dicotomia autenticidadeinautenticidade, repetida algumas vezes em Ser e tempo, por entendermos que ela carrega consigo uma forte tonalidade de Sollen (e, portanto, de ser-necessário), mesmo tratando-a sob a lupa da dicotomia adequaçãoinadequação.
} 
educacional em direito, com toda a sua tecnologia e ritualística. Independência educacional esta que não retira absolutamente nada o caráter educacional do fenômeno jurídico (cf. Capítulo 6, abaixo).

O ser-humano é chamado a decidir, ininterrupta e antecipadoramente ${ }^{154}$, sendo suas escolhas o que, no final de todas as contas, será de fato utilizado para que haja a abertura ${ }^{155}$ de sua própria existência. Ao decidir, e somente assim, o ser-humano se faz livre e revela sua liberdade com toda a sua pujança originária. É na decisão que reside assim a liberdade humana, fundamentada que se encontra no poder-ser que lhe é constitutivamente afeito.

Assim, ao decidir o ser-humano (e consequentemente, o ser-jurídico, que somente é por ser ontologicamente revelado pela presença, por ser um dos modos em que o Dasein pode ser, percebido como manualidade - Zuhandenheit - sem que com isso tencionemos afirmar que o ser-jurídico é, por qualquer razão ou viés, necessariamente ligado ao serhumano como condição ou concausa, de fato o primeiro significado para o ser-necessário tal como proposto por Aristóteles) revela que é, antes e depois de qualquer coisa, um dos " $\varepsilon v \delta \varepsilon \chi o ́ \mu \varepsilon v \alpha "$ aristotélicos; há sim (e sempre) a possiblidade de executar qualquer

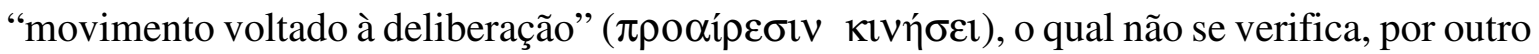
lado, nos seres agrilhoados às limitações do ser-necessário.

O ser-humano é assim constitutiva e ontologicamente um " $\varepsilon v \delta \varepsilon \chi o ́ \mu \varepsilon v o v "$, um ser que pode ser diferente do que é, sempre que assim decidi-lo (ainda que peleje ou mesmo não consiga alcançar a decisão pretendida mediante sua atualização). E nesse ponto, enfïm, que

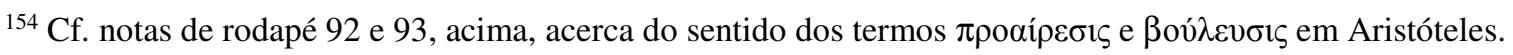

${ }^{155}$ Não é pouco salientar a evidente aproximação linguística entre os vocábulos que Heidegger utiliza em Ser e tempo para designar a decisão (Entschlossenheit) e a abertura (Erschlossenheit). Neste sentido, a Professora Márcia Schuback leciona que a palavra alemã utilizada para decisão "é um derivado do verbo schliessen que significa fechar, trancar. O prefixo ent acrescenta a ideia de um movimento em sentido contrário e daí o significado de destrancar, abrir. Uma das modalidades de exercício da presença é o destrancar-se e abrir-se para... que, no tocante à dinâmica de si-mesma, designa a experiência de determinação, resolução. Para exprimir toda essa envergadura de sentido, a tradução se valeu do processo semelhante designado pela palavra decidir, decisão cujo sentido primordial se constrói em torno do movimento de arrancar, separar (scindere)." (HEIDEGGER, 2012, p. 579, nota 76 da tradutora). Para demonstrar a congruência existente entre ambas as definições, no que diz respeito à abertura a Professora Márcia Schuback afirma que a presença "realiza-se em descobrindo. $\mathrm{O}$ modo de abertura próprio da presença distingue-se da descoberta na medida em que ela se revela para si mesma, exercendo o papel de revelador. Esse modo de revelação da presença, Ser e tempo o chamou de abertura. A descoberta dos entes não dotados do caráter de presença se faz como ser-descobridor da presença numa abertura. Abrir e abertura, porém, não têm o uso que apresentam em alemão schliessen e Schluss de concluir e conclusão dentro de um raciocínio. Nesse sentido, schliessen (abrir) em alemão diz igualmente fechar, fecho, fechamento." (HEIDEGGER, 2012, p. 567-568, nota 25 da tradutora).
} 
reside o fundamento de sua liberdade (enquanto poder-ser existencial) e de seu comportamento fenomenal: ambos se revelam, podendo ser a partir daí enunciados, desde

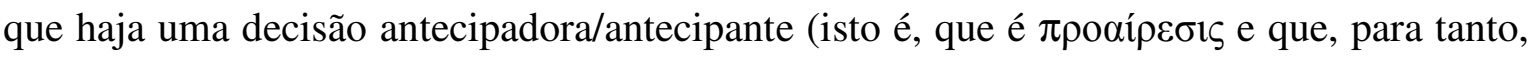

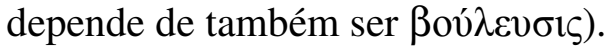

Para concluirmos, podemos dialogar novamente Heidegger:

A decisão é um modo privilegiado de abertura da presença. A abertura já foi interpretada, existencialmente, como verdade originária. Primariamente, esta não é, em absoluto, uma qualidade do "juízo" e nem tampouco de um determinado comportamento, mas um constitutivo essencial do ser-no-mundo. [...]

Com a decisão conquistamos, agora, a verdade mais originária da presença porque a mais própria. (HEIDEGGER, 2012, p. 378)

E para arrematarmos de vez o assunto, Heidegger, mais uma vez:

A decisão não desprende a presença, enquanto ser-si-mesmo mais próprio, de seu mundo, ela não a isola num eu solto no ar. E como poderia, se a presença, no sentido de abertura própria, nada mais é propriamente do que ser-no-mundo? [...] A presença decidida se liberta para seu mundo a partir daquilo em virtude de que o poder-ser se escolhe a si mesmo. Somente a decisão de si mesma coloca a presença na possibilidade de, sendo com outros, se deixar "ser" em seu poder-ser mais próprio e, juntamente com este, abrir a preocupação liberadora e antecipadora. A presença decidida pode tornar-se "consciência" [Gewissen] dos outros. Somente a partir do ser si-mesma mais próprio da decisão é que brota a convivência em sentido próprio. [...]

Mas em virtude de que a presença se decide na decisão? Para que ela deve se decidir? Somente o decisivo pode dar a resposta. Seria uma total incompreensão do fenômeno da decisão pretender que ele seja meramente um apoderar-se das possiblidades apresentadas e recomendadas. $\underline{O}$ decisivo é justamente o projeto e a determinação que abrem as possibilidades faticamente dadas a cada vez. (HEIDEGGER, 2012, p. 379-380, grifos nossos) 


\section{CAPÍTULO 6. CONSIDERAÇÕES FINAIS}

Desta modo finalizamos nossas observações, comentários e análises relativamente à Guilhotina de Hume, examinada sob o viés ontológico e existencial (fenomenológico).

Em premida síntese, esperamos ter argumentado de maneira minimamente

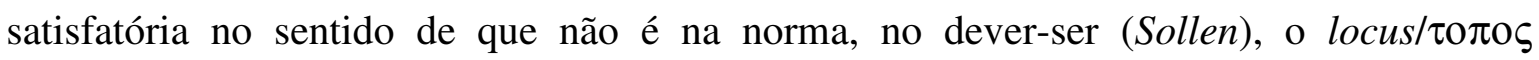
filosófico-argumentativo pelo que podemos de fato perquirir acerca do fundamento abissal (Ur-sprung Ab-grund) do fenômeno jurídico (o que no final permite o porquê em torno do tema).

Na mesma linha, também entendemos que apenas dizer que tal fundamento poderia ser localizado no ser (Sein) em contraste com o dever-ser pouco acrescenta ao debate pois, como vimos (segundo os ensinamentos aristotélicos e heideggerianos), o ser se diz de muitas

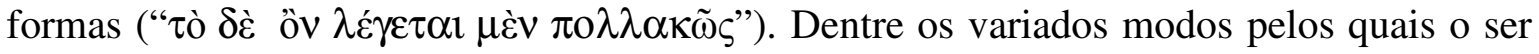
se diz, qual poderíamos nos apropriar, (pré)compreender e projetar para apreender a verdade (social e metafísica) do fenômeno jurídico?

Entendemos que podemos buscar esta verdade jurídica (que é intuitiva e revelada, e não correspondencial-estratificada) especificamente na possibilidade existencial (poderser-e-não-ser, simultaneamente, enquanto amálgama das contradições e dramaticidade da existência), que assim se afirma como o fundamento abissal e originário (Ur-Sprung Abgrund) do fenômeno jurídico. Possibilidade existencial esta que não: (i) com-partilha ou com-sagra a linguagem do ser-necessário (aquilo que que não pode ser de outra maneira -

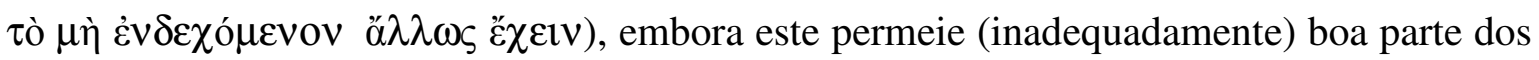
discursos jusfilosóficos (ainda que sub-repticiamente); (ii) tem a ver com a potência aristotélica (ser-potência), que nada mais é do que uma mera espera/confiança pela/na atualização (necessária, no final do dia, sob pena de incompletude ou mesmo incongruência); (iii) se aferroa aos grilhões e insipidez da lógica modal, que peca por muitas vezes não depender de qualquer referência fática e por estar lastreada na ideia de possibilidade matemática proposta por Leibniz (mundos possíveis), ficando refém mesmo dos axiomas e determinações assumidos/quistos pelos seus respectivos teóricos. O ser-humano é,

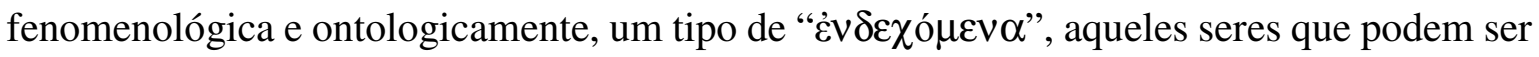


de outro modo do que agora são, e que, segundo Aristóteles, "podem se tornar verdadeiros e falsos", simultaneamente.

\section{O ser-humano é, antes de qualquer coisa, pura transcendência e superação.}

Nesta toada, vimos ainda que a possibilidade existencial é (constitutiva e, portanto, ontologicamente) liberdade (ser-livre), que por sua vez acaba por se tornar parte integrante e inescapável do ser-humano (Dasein; presença; ser-aí; $\pi \rho \alpha ́ \xi ı \varsigma)$. O poder-ser (enquanto fundamento abissal do fenômeno jurídico) é assim um "ser-suspenso", tornando-se a dimensão ontológica da liberdade do Dasein (prática, per se), que se revela/manifesta por meio das decisões tomadas diuturnamente pelos próprios seres-humanos (decisões estas que, de certa forma, acabam por nulificar a própria ideia de possibilidade, atualizando-a).

Tencionamos assim ressaltar que a verdade originária do ser-jurídico (que podemos considerar como uma forma de apreensão/compreensão da própria busca por justiça) não é alcançável por meio de meras construções linguístico-proposicionais: embora não haja dúvida que o ser-jurídico (como todo ser) é na linguagem (mas não nela existe, pois a existência é uma marca exclusiva do ser-humano, em seu diuturno atravessar-por), ambos são (pré)compreendidos de maneira muito mais aberta e intuitiva, de modo que seu conteúdo e alcance é criado, recortado e (re)contado do (e no) continuum espaço-temporal a partir e dentro da narrativa mitológica, circunvisão e horizonte de cada presença, individualmente considerada (sem com isso a reduzirmos à egolatria do jusracionalismo de viés cartesiano).

A percepção do ser-jurídico, desta maneira, não é lógica e proposicionalmente enunciada ou construída; sua enunciação/construção depende intimamente de ter o Dasein (pré)compreendido-o (este ser) como normativo, projetando-o/imitando-o em sua atuação quotidiana.

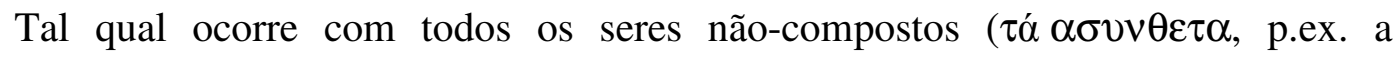
circunferência do círculo segundo Aristóteles), se o ser-jurídico não for intuído/tocado

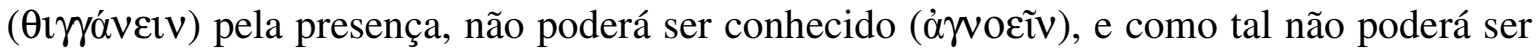
jamais verdadeiramente enunciado e presentificado pela presença: sua enunciação e presentificação, que sempre ocorre pela e na presença, depende de sua revelação/intuição 
que, por outro lado, de tão dependente que é da circunvisão (Umsicht) e do horizonte do Dasein, acaba sendo impossível (e até mesmo indesejável) qualquer tentativa de definição (definitio) do que é ser-jurídico, ser-ético, ser-religioso, etc. Em suma: este ou é sentido/conhecido, ou simplesmente não é.

A verdade do ser-jurídico (e do ser-normativo em geral) está assim muito mais

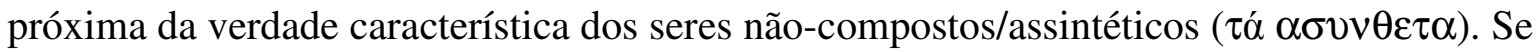
considerarmos a verdade como correlato da justiça, sua busca passa a ser metafisicamente revelada pelo Dasein, por sua (pré)compreensão narrativa (mÿthos) e projeção (mímesis).

O próprio direito, assim, passa a ser encarado como um processo (e não um objeto)

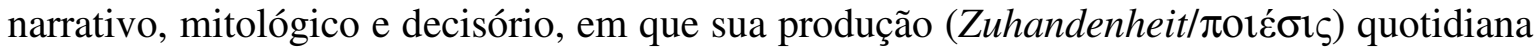
se transforma em atividade mimética ${ }^{156}$, pré-comprensional e intuitiva ${ }^{157}$. Com efeito, tais narrativas (mitos) não possuem apenas o caráter de uma história imparcialmente (re)contada. Servem (ser-para) como parte da formação do próprio ser-humano ${ }^{158}$, enquanto instrumento que é para a ação/produção.

O direito, assim, passa ser identificado como uma tecnologia (Zeug/um ser-para) narrativa à disposição da presença (enquanto Zuhandenheit/manualidade) para que dela possa se fazer-algo; mas uma tecnologia de caráter educacional e de formação ${ }^{159}$, não

\footnotetext{
${ }^{156}$ Consoante os ensinamentos de Ricoeur, “[...] o fato de o termo práxis pertencer tanto ao domínio real, desenvolvido pela ética, como ao domínio imaginário, desenvolvido pela poética, sugere que a mímesis não tem somente uma função de corte, mas também de ligação, que estabelece precisamente o estatuto de transposição 'metafórica' do campo prático pelo mÿthos." (RICOEUR, 2010, v. I, p. 82).

157 "Por maior que seja a força de inovação da composição poética no campo de nossa experiência temporal, a composição da intriga [mÿthos] está enraizada numa pré-compreensão do mundo da ação: de suas estruturas inteligíveis, de seus recursos simbólicos e de seu caráter temporal.” (RICOEUR, 2010, v. I, p. 96). Afinal, a inteligibilidade gerada pelo mito "[...] encontra uma primeira ancoragem em nossa competência para utilizar de maneira significativa a rede conceitual que distingue estruturalmente o domínio da ação do domínio do movimento físico" (RICOEUR, 2010, v. I, p. 97), sendo que dominar referida rede conceitual "no seu conjunto e cada termo a título de membro do conjunto é ter a competência que podemos chamar compreensão prática." (RICOEUR, 2010, v. I, p. 98).

158 “O conceito de imitação de ação pode portanto ser ampliado para além do 'romance de ação', no sentido estrito da palavra, e incluir o 'romance de caráter' e o 'romance de pensamento', em nome do poder abrangente da intriga com relação às categorias rigorosamente definidas de incidente, de personagem (ou de caráter) e de pensamento. A esfera delimitada pelo conceito de mímesis praxeos se estende até onde se estende a capacidade a narrativa de 'apresentar' seu objeto por estratégias narrativas que engendram totalidades singulares capazes de produzir um 'prazer próprio' por um jogo de inferências, de expectativas e de respostas emocionais, pelo lado do leitor.” (RICOEUR, 2010, v. II, p. 17).

159 “A educação é uma função tão natural e universal da comunidade humana, que, pela sua própria evidência, leva muito tempo a atingir a plena consciência daqueles que a recebem e praticam, sendo, por isso, relativamente tardio o seu primeiro vestígio na tradição literária. O seu conteúdo, aproximadamente o mesmo
} 
meramente técnico-produtiva (como seria o caso, por exemplo, de uma técnica cirúrgicooperatória), e muito menos coacionista (a coação, de fato, é apenas mais um elemento narrativo, não possuindo qualquer caráter fundante, como muitos juspositivistas pretendem fazer crer).

Ademais, não consideramos a decisão (enquanto momento-movimento de revelação da liberdade humana e do caráter fundante do poder-ser) como se meramente jurídica fosse, que é normalmente o foco neste tipo de análise. Sob nossa perspectiva, a posição tradicional empobrece, desexistencializa e desincorpora o fenômeno jurídico de seu fundamento abissal e originário, que é a decisão antecipadora/antecipante tomada com base unicamente (embora não trivialmente) na pré-compreensão e circunvisão que o Dasein tem do seu mundo.

Relembrando um fragmento da Ética à Nicômaco que já transcrevemos, "o que é discernido a partir da deliberação é o que é decidido de antemão" na mesma medida dos antigos reis, os quais "só comunicavam ao povo aquelas coisas que previamente já tinham decidido".

Dito de outra maneira: a adequação dita jurídica de determinada conduta emana de uma decisão tomada dentre uma quase infinidade de possibilidades que, por seu turno, reciprocamente acabam por demandar do ser-humano, ininterruptamente, uma tomada de decisão, entre uma superabundância delas, enquanto troca para conseguirmos viver em sociedade.

De qualquer maneira, como já admoestado pelo Professor Ari Marcelo Solon em sua obra acerca da soberania jurídica ${ }^{160}$, não é de agora que se apregoa uma aproximação fundativa entre a decisão e o direito. De fato:

em todos os povos, é ao mesmo tempo moral e prático. [...] Reveste, em parte, a forma de mandamentos, como: honrar os deuses, honrar pai e mãe, respeitar os estrangeiros; consiste [a educação] por outro lado numa série de preceitos sobre a moralidade externa e em regras de prudência para a vida, transmitidas oralmente pelos séculos afora; e apresenta-se ainda como comunicação de conhecimentos e aptidões profissionais a cujo conjunto, na medida em que é transmissível, os gregos deram o nome de tékhne." (JAEGER, 2013, p. 21).

160 SOLON, Ari Marcelo. Teoria da soberania como problema da norma jurídica e da decisão. Porto Alegre: Sergio Antonio Fabris, 1997. 
[..] a tese de uma convergência metodológica entre o elemento decisório e o normativo (...) não é uma novidade (...), [sendo que] ela foi antecipada no Brasil pelos trabalhos de Tércio Sampaio Ferraz Jr. ao dissertar sobre a 'decidibilidade de conflitos como problema central da ciência dogmática do direito'. (SOLON, 1997, p. 187).

Contudo, novamente gostaríamos de salientar que normalmente este tipo de análise leva em consideração apenas a decisão jurídica como fundativa; nossa ideia é ampliar o exame da decidibilidade para abarcar ainda processos decisórios de caráter humano, e não técnico-sacerdotal.

Mas uma dúvida ainda resta: se a possibilidade existencial (ser e não ser, ao mesmo tempo, pela qual a existência, haurida de todas as contradições, complicações, expectativas, angústias, alegrias e esperanças próprias do Dasein, se revela decisoriamente) é o fundamento do fenômeno normativo, estaríamos todos fadados a um cinismo totalitário e selvagem em que tudo é permitido (por ser possível)? Em outras palavras: haveria assim uma completa indiferença entre ser-justo (ser-normativamente-verdadeiro) e ser-injusto?

Em primeiro lugar, cumpre-nos ressaltar que obtemperar acerca destes questionamentos foge do tema desta Dissertação, em que ensaiamos buscar o fundamento originário e abissal do fenômeno normativo (que é o poder-ser decisoriamente revelado). Para responder a tais outras questões, com efeito, a pergunta-mote do trabalho deveria ser outra (pelo menos do ponto de vista ontológico e fenomenológico): qual é o ser (locus temporal em que reside o fundamento abissal e originário) da possibilidade existencial, mormente sob o viés normativo-comportamental?

Em que pese o fato de nos parecer de pronto que não, não é possível que haja qualquer indiferença entre ser-justo e ser-injusto, sendo essencial o questionamento, entendemos que uma análise ontológica e fenomenológica neste sentido dependeria de aprofundarmos o debate para incluirmos questões outras envolvendo estética, sentimento religioso e política pois somente por meio de bardos poderíamos buscar o ser da possibilidade existencial, cuja verdade revelar-se-ia na forma de justiça (e de maneira intuitiva). 
Dito de outro modo: somente através do sentimento estético/político e religioso poderíamos alcançar a verdade originária (justiça) da possibilidade existencial, que é, por seu turno, o fundamento abissal e originário do próprio fenômeno normativocomportamental.

Concluindo, gostaríamos de finalizar na linha do pensamento de Heidegger ao escrever um ensaio denominado Por quê os poetas ${ }^{161}$, em 1946:

Long is the desolate time of the world's night. It reaches [gelangen] its midpoint only at length [lang]. In the midnight of this night, the desolation of the time is the greatest. The destitute time is then no longer able even to experience its distress. [...] Nonetheless, the world's night is to be thought as a destiny that takes place this side of pessimism and optimism. [...] The time is long because even terror, treated in itself as a ground for a turn, can do nothing as long as there is no turn among mortals. It turns, however, only when mortals come into their own essence. Their essence is based on the fact that they are the ones who reach into the abyss, rather than the gods. Mortals keep closer to absence (if we think of their essence) because they are concerned by presence, the name of being since antiquity. [...] The mortal who is to reach into the abyss rather than or differentlyfrom others experiences the marks [Merkmale] that the abyss observes [vermerkt]. These, for the poet, are the tracks of the fugitive gods. (HEIDEGGER, 2002, p. 201-202).

Se a justiça é possível, devemos buscá-la mediante uma superação poética e religiosa do fenômeno normativo, para que possamos caminhar sobre as pegadas destes "deuses fugitivos" em busca do âmago mortal, finito e maravilhosamente complexo e poiético (sic) do ser-humano.

${ }^{161}$ In: HEIDEGGER, Martin. Off the beaten track. Tradução de Julian Young e Kenneth Haynes. New York/EUA: Cambridge University Press, 2002, p. 200-241. 


\section{BIBLIOGRAFIA}

ABBAGNANO, Nicola. Possibilità e libertà. - Torino: Taylor Torino Editore, 1956.

História da filosofia. Tradução de António Borges Coelho et al. Vol. VIII - Lisboa: Editorial Presença. 5ª ed., 2000 (ABBAGNANO, 2000a).

História da filosofia. Tradução de António Borges Coelho et al. Vol. VII - Lisboa: Editorial Presença. $4^{\mathrm{a}}$ ed., 2000 (ABBAGNANO, 2000b).

História da filosofia. Tradução de António Borges Coelho et al. Vol. I - Lisboa: Editorial Presença. $7^{\text {a }}$ ed., 2006.

Dicionário de filosofia. Tradução da $1^{\mathrm{a}}$ edição brasileira coordenada e revista por Alfredo Bossi; revisão da tradução e tradução dos novos textos por Ivone Castilho Benedetti. - 5 edição. São Paulo: Martins Fontes, 2007.

ALVES, José Carlos Moreira. Direito romano. - $5^{\text {a }}$ ed., vol. I. Rio de Janeiro: Forense, 1983.

ARENDT, Hanna. A condição humana. - Tradução de Roberto Raposo, revisão técnica de Adriano Correia. 11ª edição. Rio de Janeiro: Forense Universitária, 2010.

ARISTÓTELES. Ética a Nicômaco. Tradução do grego por António de Castro Caeiro. São Paulo: Atlas, 2009. Original obtido baseado em texto compilado por J.Bywater em 1894, disponível em:

$<$ http://www.perseus.tufts.edu/hopper/text;jsessionid=A015E26CF73BAE15857CDCA0F6 AD1BBA?doc=Perseus\%3atext\%3a1999.01.0053 $>$, página acessada pela última vez em $10 / 01 / 2016$.

. Metafísica: volume I; ensaio introdutório de Giovanni Reale. Tradução de Marcelo Perine. - $2^{\mathrm{a}}$ ed. São Paulo: Edições Loyola, 2005 (ARISTÓTELES, 2005). 
Metafísica: volume II; texto grego com tradução de Giovanni Reale. Tradução de Marcelo Perine. - $3^{\mathrm{a}}$ ed. São Paulo: Edições Loyola, 2013 (ARISTÓTELES, 2013).

Metafísica: volume III; sumários e comentários. Tradução de Marcelo Perine. - $3^{\mathrm{a}}$ ed. São Paulo: Edições Loyola, 2011 (ARISTÓTELES, 2011).

De Anima. Tradução de Maria Cecília Gomes de Reis. - 2a ed.. São Paulo: Editora 34, 2012.

BASTOS, Cleverson Leite et al., Lógica modal: aspectos históricos, v.1. Curitiba: Champagnat, 2012.

BECHARA, Evanildo. Moderna gramática portuguesa. $37^{\mathrm{a}}$ ed. rev., ampl. e atual. conforme o novo Acordo Ortográfico. - Rio de Janeiro: Nova Fronteira, 2009.

BERTI, Enrico. Aristóteles no século XX. Tradução de Dion Davi Macedo. - São Paulo: Edições Loyola, 1997.

BOBBIO, Norberto. Teoria da norma jurídica. - Tradução de Fernando Pavan Baptista e Ariani Bueno Sudatti. Bauru, SP: EDIPRO, 2001.

CALDAS, Camilo Onoda et al. Manual de metodologia do direito: estudo e pesquisa. São Paulo: Quartier Latin, 2010.

CASSIN, Barbara. Aristóteles e o lógos: contos da fenomenologia comum. - Tradução de Luiz Paulo Rouanet. São Paulo: Edições Loyola, 1999.

CHELLAS, Brian F., Modal logic: an introduction. Cambridge: Cambridge University Press, 1999.

COMPARATO, Fábio Konder. Ética: direito, moral e religião no mundo moderno. $-2^{\text {a }}$ ed. São Paulo: Companhia das Letras, 2013. 
COSCARELLI, Bruno Costa. Introdução à lógica modal. São Paulo: Biblioteca 24horas, 2012.

ECO, Umberto. Kant e o ornitorrinco. Tradução de Ana Thereza B. Vieira - Rio de Janeiro: Record, 1998.

FERRAZ JÚNIOR, Tércio Sampaio. Introdução ao estudo do direito: técnica, decisão, dominação. - $2^{a}$ ed. São Paulo: Atlas, 1994.

FERREIRA, Aurélio Buarque de Holanda. Novo Aurélio Século XXI: o dicionário da língua portuguesa. $-3^{\text {a }}$ ed. Rio de Janeiro: Nova Fronteira, 1999.

GADAMER, Hans-Georg. Verdade e método. - Tradução de Flávio Paulo Meurer. Vol. I. $12^{\mathrm{a}}$ ed. Petrópolis/RJ: Vozes. Bragança Paulista/SP: Editora Universitária São Francisco, 2012.

GAIMAN, Neil. Sandman: Edição Definitiva. - Tradução de Jotapê Martins e Fabiano Denardin. $2^{a}$ ed., vol. II (Estação das Brumas: Um Prólogo). Barueri, SP: Panini Books, 2011.

HART, Herbert Lionel Adolphus. The concept of law. - $3^{\text {a }}$ ed. New York: Oxford University Press, 1998 (reimpressão).

HEIDEGGER, Martin. A essência do fundamento. Tradução de Artur Morão. - Lisboa: Edições 70, 1988.

Off the beaten track. Tradução de Julian Young e Kenneth Haynes. New York/EUA: Cambridge University Press, 2002.

A origem da obra de arte. Tradução de Idalina Azevedo e Manuel António de Castro. - São Paulo: Edições 70, 2010.

Ser e tempo. - Tradução de Marcia Sá Cavalcante Schuback. $6^{\mathrm{a}}$ ed.

- Petrópolis/RJ: Vozes; Bragança Paulista/SP: Editora Universitária São Francisco, 2012. 
HERÁCLITO. Fragments. - Tradução por Brooks Haxton. New York: Penguin, 2001.

HESÍODO. Teogonia. Tradução de Christian Werner. - São Paulo: Hedra, 2013.

HOBBES, Thomas. Leviatã, ou matéria, forma e poder de um estado eclesiástico e civil. - Tradução de Rosina D’Angina. 2a ed. São Paulo: Martin Claret, 2012.

HOUAISS, Antônio. Grande Dicionário Houaiss da língua portuguesa. Disponível em $<$ http://houaiss.uol.com.br/> (grifos nossos). Acessado em 10/01/2016.

HUME, David. A Treatise of Human Nature. Oxford: Oxford University Press, 2009.

IHERING, Rudolf von. A luta pelo direito. - Tradução de José Cretella Jr. e Agnes Cretella. $2^{a}$ ed. São Paulo: Editora Revista dos Tribunais, 2001.

JAEGER, Werner Wilhelm. Paideia: a formação do homem grego. Tradução de Artur M. Parreira. - 6a ed. São Paulo: Editora WMF Martins Fontes, 2013.

JASPERS, Karl. The philosophy of existence. Tradução de Richard F. Grabay. - $7^{\mathrm{a}}$ ed. Philadelphia: University of Pennsylvania Press, 1995.

JUBIEN, Michael. Possibility. Oxford: Oxford University Press, 2011.

KAHN, Charles H. A arte e o pensamento de Heráclito: uma edição dos fragmentos com tradução e comentário. - Tradução de Élcio de Gusmão Verçosa Filho. São Paulo: Paulus, 2009.

KANT, Immanuel. A metafísica dos costumes. Tradução de Edson Bini. - $2^{\mathrm{a}}$ ed. Bauru/SP: EDIPRO, 2008.

Crítica da razão prática. Tradução de Rodolfo Schaefer. - $3^{a}$ ed. São Paulo: Martin Claret, 2011. 
Crítica da razão pura. Tradução e notas de Fernando Costa Mattos. $3^{\text {a }}$ ed. Petrópolis/RJ: Vozes; Bragança Paulista/SP: Editora Universitária São Francisco, 2013.

KELSEN, Hans. O problema da justiça. - Tradução de João Baptista Machado. $2^{a}$ ed. São Paulo: Martins Fontes, 1996.

. Teoria pura do direito. - Tradução de João Baptista Machado. $6^{\mathrm{a}}$ ed. São Paulo: Martins Fontes, 1998.

. O que é justiça?: a justiça, o direito e a política no espelho da ciência.

- Tradução de Luís Carlos Borges. $3^{\mathrm{a}}$ ed. São Paulo: Martins Fontes, 2001.

General theory of law and state. - Cambridge/Massachusetts: Harvard University Press, 2007.

KOESTLER, Arthur. Os sonâmbulos: história das concepções do homem sobre o universo. - Tradução de Alberto Denis. São Paulo: IBRASA, 1961.

MAMAN, Jeannette Antonios. Fenomenologia existencial do direito: crítica do pensamento jurídico brasileiro. 2a ed. São Paulo: Quartier Latin. 2003.

MANiATOGLOU, Maria da Piedade Faria. Dicionário Grego-Português. - Porto: Porto Editora, 2010.

MASCARO, Alysson Leandro. Filosofia do direito. - $2^{\text {a }}$ ed. São Paulo: Atlas, 2012. Introdução ao estudo do direito. - $4^{\mathrm{a}}$ ed. São Paulo: Atlas, 2013.

OLIVECRONA, Karl. Linguagem jurídica e realidade. Tradução de Edson Bini. São Paulo: Quartier Latin, 2005. 
PARMÊNIDES. The fragments of Parmenides, by A.H.Coxon. - Tradução de Richard McKirahan. Las Vegas: Parmenides Publishing/A.H. Coxon 2009.

PERELMAN, Chaïm, et al. Tratado da argumentação. - Tradução de Maria Ermantina Galvão G. Pereira. São Paulo: Martins Fontes, 1996.

PETER, Francis Edwards. Greek philosophical terms: a historical lexicon. - Nova York, EUA: New York University Press, 1967.

PIAGET, Jean et al. Possibility and necessity. Volume 1: The role of possibility in cognitive development. - Tradução de Helga Feider. Minneapolis/Minnesota: University Minnesota Press, 1987.

PLATÃO. Górgias. - Tradução de Benjamin Jowett. Disponível em: <http://www.gutenberg.org/files/1672/1672-h/1672-h.htm>. Página acessada pela última vez em 10/01/2016.

PLATINGA, Alvin. The nature of necessity. Oxford: Oxford University Press, 2010.

PRUSS, Alexander R. Actuality, possibility and worlds. Nova York: The Continuum International Publishing Group, 2011.

RAGON, Elói. Gramática grega. - Tradução de Cecília Bartalotti. São Paulo: Odysseus Editora, 2011.

REIS, Róbson Ramos dos. Aspectos da modalidade: a noção de possibilidade na fenomenologia hermenêutica. Rio de Janeiro: Via Vérita, 2014.

RICOEUR, Paul. Tempo e narrativa. - Tradução de Claudia Berliner. - vol. I e II. São Paulo: Editora WMF Martins Fontes, 2010.

SCHURZ, Gehard. The is-ought problem: an investigation in philosophic logic. Dordrecht: Kluwer, 1997. 
SOLON, Ari Marcelo. Teoria da soberania como problema da norma jurídica e da decisão. Porto Alegre: Sergio Antonio Fabris, 1997.

SOLON, Ari Marcelo. Dever jurídico e teoria realista do direito. Porto Alegre: Sergio Antonio Fabris, 2000.

TOOLEY, Michael (editor). Analytical Metaphics (a collection of essays). Necessity and possibility: the metaphysics of modality. Nova York: Routledge, 2011.

VILANOVA, Lourival. Causalidade e relação no direito. - 4a . ed. São Paulo: Editora Revistas dos Tribunais, 2000.

VOLPI, Franco. Heidegger e Aristotele. - Bari/Itália: Editori Laterza, 2010. 